Florida International University

FIU Digital Commons

FIU Electronic Theses and Dissertations

University Graduate School

6-15-2020

\title{
Beyond Predation: How Do Consumers Mediate Bottom-up Processes in Ecosystems?
}

Bradley Austin Strickland

bstri007@fiu.edu

Follow this and additional works at: https://digitalcommons.fiu.edu/etd

Part of the Behavior and Ethology Commons, Biodiversity Commons, Marine Biology Commons, Population Biology Commons, Terrestrial and Aquatic Ecology Commons, and the Zoology Commons

\section{Recommended Citation}

Strickland, Bradley Austin, "Beyond Predation: How Do Consumers Mediate Bottom-up Processes in Ecosystems?" (2020). FIU Electronic Theses and Dissertations. 4520.

https://digitalcommons.fiu.edu/etd/4520

This work is brought to you for free and open access by the University Graduate School at FIU Digital Commons. It has been accepted for inclusion in FIU Electronic Theses and Dissertations by an authorized administrator of FIU Digital Commons. For more information, please contact dcc@fiu.edu. 


\section{FLORIDA INTERNATIONAL UNIVERSITY}

Miami, Florida

\section{BEYOND PREDATION: HOW DO CONSUMERS MEDIATE BOTTOM-UP PROCESSES IN ECOSYSTEMS?}

A dissertation submitted in partial fulfillment of

the requirements for the degree of

DOCTOR OF PHILOSOPHY

in

BIOLOGY

by

Bradley Austin Strickland 
To: Dean Michael R. Heithaus

College of Arts, Sciences and Education

This dissertation, written by Bradley Austin Strickland, and entitled Beyond Predation: How Do Consumers Mediate Bottom-up Processes in Ecosystems?, having been approved in respect to style and intellectual content, is referred to you for judgment.

We have read this dissertation and recommend that it be approved.

Frank J. Mazzotti

Yannis P. Papastamatiou

Jennifer S. Rehage

Joel C. Trexler

Michael R. Heithaus, Major Professor

Date of Defense: June 15, 2020

The dissertation of Bradley Austin Strickland is approved.

Dean Michael R. Heithaus

College of Arts, Sciences and Education

Andrés G. Gil

Vice President for Research and Economic Development and Dean of the University Graduate School

Florida International University, 2020 
C Copyright 2020 by Bradley Austin Strickland All rights reserved. 


\section{DEDICATION}

To Katherine, my lovely wife, whose beauty and love inspires me every day. And to my parents, Delmer and Suanna, who always give me encouragement. 


\section{ACKNOWLEDGMENTS}

I appreciate the work of my advisor, Mike Heithaus, who has taught me so much about how to communicate science. He has been an inspiring role model and an encouraging and energetic teacher every step of the way. I could not have done this work without the support of my committee. Joel Trexler is one of the most significant mentors I have had in my career. I really appreciate his patience and the many hours spent molding me into a better scientist. Jennifer Rehage has always been supportive and has taught me so much about the Everglades. Frank Mazzotti is likely the most influential crocodilian researcher alive; I have greatly benefited from his expertise and incredible understanding of alligators. Yannis Papastamatiou and his incredible knowledge of movement ecology and physiology has been a valuable contribution to my work.

I would like to acknowledge the University Graduate School at FIU for providing both the Doctoral Evidence Acquisition Fellowship and the Dissertation Year Fellowship. These two awards were instrumental in helping me collect data and write my dissertation. I also appreciate the Everglades Foundation and FIU who provided a research fellowship that allowed me to develop and fund part of my dissertation. Much of the research within this dissertation was graciously funded by the National Science Foundation's Long-Term Ecological Research grant to the Florida Coastal Everglades site. It is a pleasure to be a part of such an awesome team of FCE scientists working hard to understand the Everglades. John Kominoski and Evelyn Gaiser have been wonderful mentors and champions for graduate student development.

I also want to thank a huge number of people who have given their time and energy to help in both the field and lab. Kirk Gastrich, Phil Matich, Rob Nowicki, and 
Adam Rosenblatt have set fantastic examples as scientists and have been so generous with their time and help. Bill Chamberlain, Valerie Hall, Rafael Gonzalez, SERC, Institute of Water, FIU, and Everglades National Park staff have been incredible in their logistical support. Sarah Sisco, Yamilla Samara, and Laura Garcia Barcia dedicated hundreds of hours to make this work possible. Jordan Massie, Ross Boucek, and Natasha Viadero are awesome field biologists and I have been happy to learn from them. There is no way this work could have been done without the muscle and brains of Peter Flood; he is both a great friend and collaborator. I also want to thank Maurits van Zinnicq Bergmann and Zoran Bursac for help with statistical modeling and Megan Kelley with her expertise in nutrient transportation. Venus Garcia, Maria Sabando, and countless other technicians and volunteers across multiple labs have helped in both the field and lab. I also appreciate all of the Croc Docs team (especially Jeff Beauchamp, Michiko Squires, Seth Farris, Mike Cherkiss, and others) that helped deploy tags. I have a large group of friends at FIU who have made this journey a pleasure and I could not imagine a better group of people. I have benefited greatly from my friendship with Alex Ontkos and his understanding of the Everglades. I appreciate all of my lab mates, in particular the incredible support of Camila Cáceres, Frances Farabaugh, and Valeria Paz. I want to thank both Richard Brinn and Lorilee Valientes for making me a better instructor, and I appreciate all the professors who have made me a better scientist.

I am so grateful to have a supportive and loving family. My parents, Delmer and Suanna, have always worked hard in life to provide for me, and have encouraged me to focus on making myself a better person. Their sacrifices made me who I am today. I am blessed with the close friendship of both of my siblings, Carrie and Alex. I am also 
grateful to have married into a kind and generous family. Lastly, I want to thank my wife, Katherine. She has been instrumental in my ability to do this work. This dissertation is as much hers as it is mine. Her love and encouragement is the reason words ever made it to paper. 


\title{
ABSTRACT OF THE DISSERTATION \\ BEYOND PREDATION: HOW DO CONSUMERS MEDIATE BOTTOM-UP \\ PROCESSES IN ECOSYSTEMS?
}

\author{
by
}

Bradley Austin Strickland

Florida International University, 2020

Miami, Florida

Professor Michael R. Heithaus, Major Professor

By eating and scaring prey, predators can exert strong effects on communities and ecosystems. In addition, some animals may physically alter habitats and may recycle nutrients through digestion, both of which affect resources available to producers. Bottom-up effects initiated by large predators have not been well-studied and could prove to be important for understanding food webs and how ecosystems function. American alligators (Alligator mississippiensis) are abundant mobile predators that are capable of engineering aquatic habitats by moving organic material across ecosystem boundaries and creating and maintaining alligator ponds. In this dissertation, I documented the scale of ecological impacts of alligators by studying movement and habitat use across a range of environmental conditions. I observed cross-ecosystem movements against a productivity gradient from nutrient-rich marine habitats, intermediately productive midestuary zones, and oligotrophic upstream freshwater marshes. Individual variation in movement behavior may manifest into different ecological roles of individuals within the population. I also found that alligator movement and habitat use is strongly tied to hydrology and thus alligators are sensitive to the effects of restoration of freshwater 
inflow into wetlands. A field study of alligator ponds in the oligotrophic Everglades freshwater marsh revealed the engineering effects of alligators on both community structure and ecosystem function. Alligator-engineered habitats were phosphorusenriched and had dissimilar trophic structure including differences in algal, plant, and consumer communities compared to the surrounding marsh. Alligator ponds also showed shifted energy flow towards algal production compared to more detrital pathways in the marsh. Overall, I found that consumer-mediated bottom-up effects through nutrient transport and engineering are ecologically important especially in areas where increased habitat heterogeneity and nutrient enrichment may yield positive effects on primary producers and lower trophic levels. This dissertation emphasizes the importance of considering multiple pathways of trophic effects in food web models. Future work may allow us to partition the effects of the diversity of a predator and engineer's role on trophic structure and accurately predict the effects of loss of function in one or more of these roles. Such a model will greatly enhance our understanding of community and ecosystem dynamics. 


\section{TABLE OF CONTENTS}

CHAPTER

PAGE

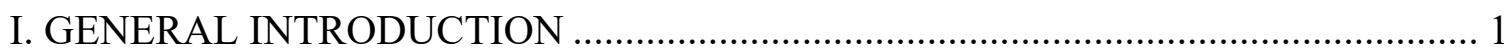

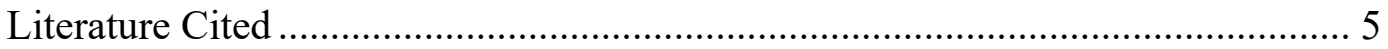

II. INDIVIDUAL VARIATION AND ABIOTIC DRIVERS OF MOVEMENT AND

HABITAT USE FOR AMERICAN ALLIGATORS IN A SUBTROPICAL ESTUARY 7

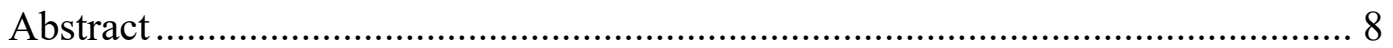

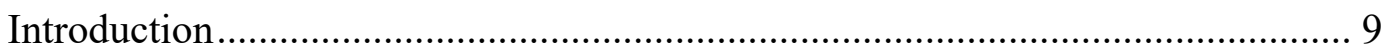

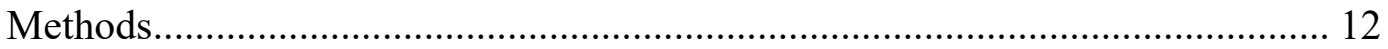

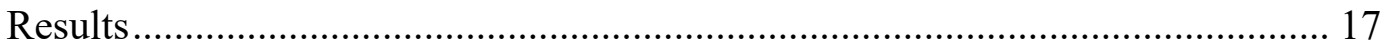

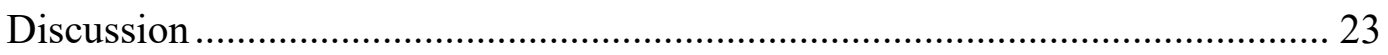

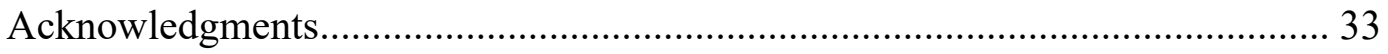

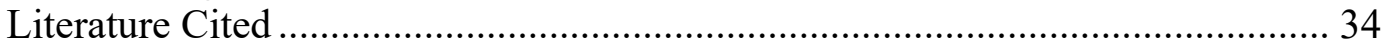

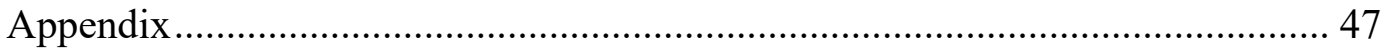

III. EFFECTS OF HYDROLOGY ON THE MOVEMENTS OF A LARGE-BODIED PREDATOR (ALLIGATOR MISSISSIPPIENSIS) IN A MANAGED-FRESHWATER

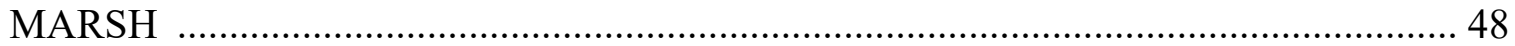

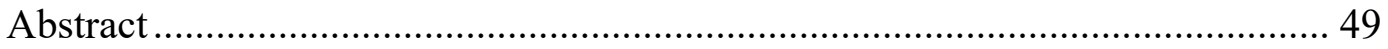

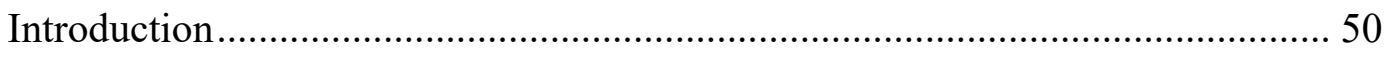

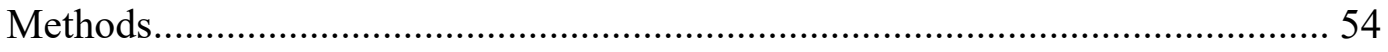

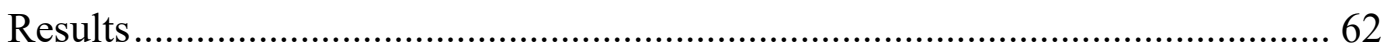

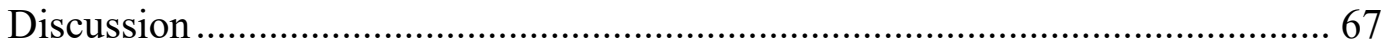

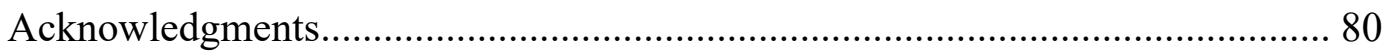

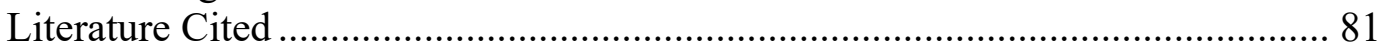

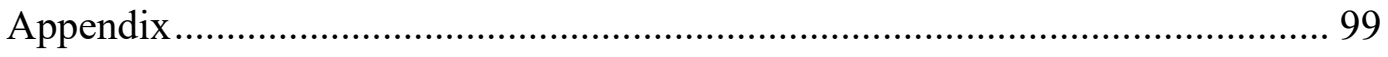

IV. TROPHIC STRUCTURE AND NUTRIENT ENRICHMENT OF PONDS

ENGINEERED BY AMERICAN ALLIGATORS IN AN OLIGOTROPHIC

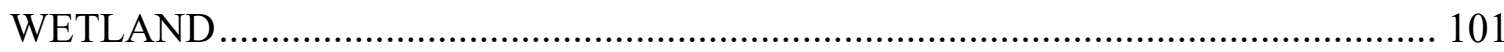

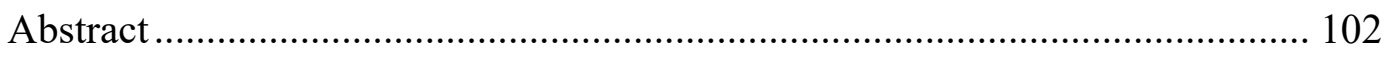

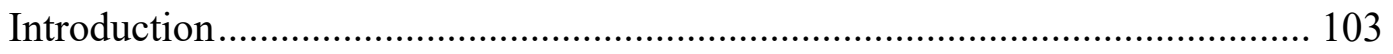

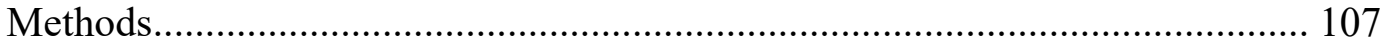

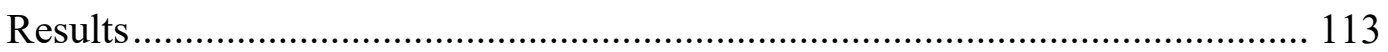

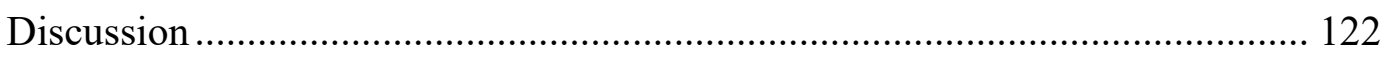

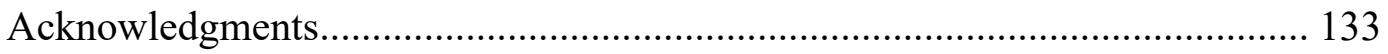

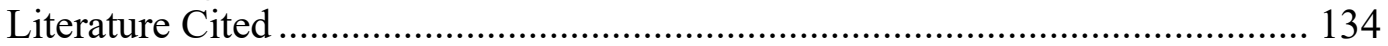

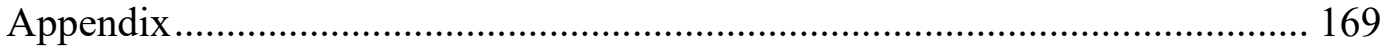

V. FATTY ACIDS REVEAL SHIFTS IN DETRITAL AND ALGAL ENERGY

PATHWAYS OF PONDS ENGINEERED BY AMERICAN ALLIGATORS IN AN

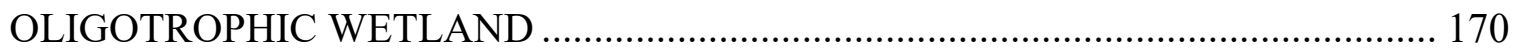

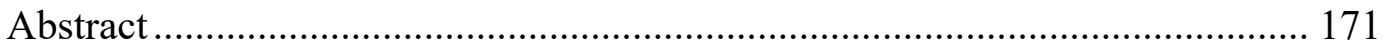




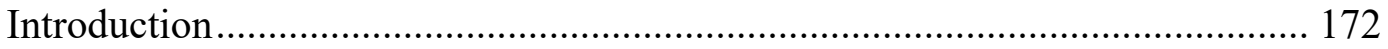

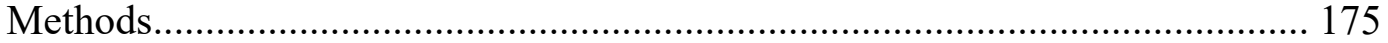

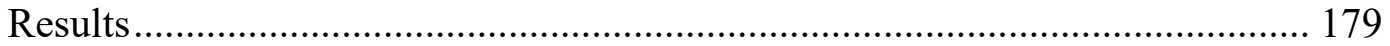

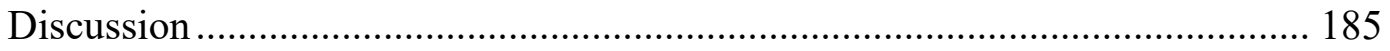

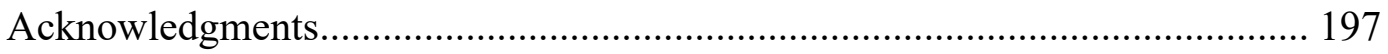

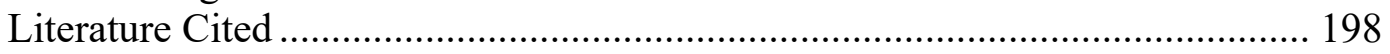

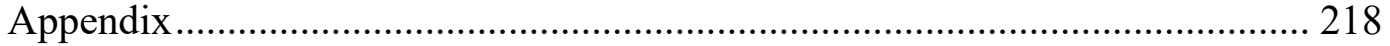

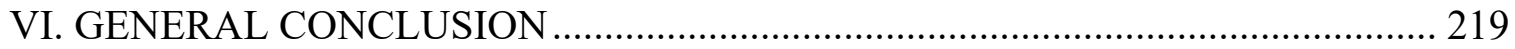

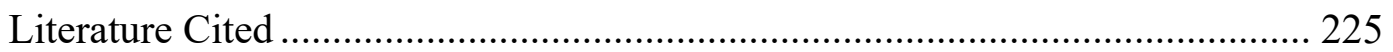

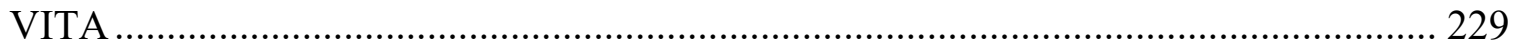




\section{LIST OF TABLES}

TABLE

PAGE

\section{CHAPTER II}

Table 1: Percent of time spent in each habitat "zone" and number and mean duration of each zone change for American alligators (Alligator mississippiensis) in Shark River Estuary, Florida, USA tracked using satellite telemetry (2013-2016) for which there were sufficient relocations

Table 2: Median and range of home range and core use area size, defined by the area in $\mathrm{km}^{2}$ of the $95 \%$ and $50 \%$ utilization distributions, respectively, and mean and standard deviation (SD) of Brownian motion variance, an indicator of movement activity, across seasons and breeding period for American alligators (Alligator mississippiensis) in Shark River Estuary, Florida, USA tracked using satellite telemetry (2013-2016) for which there were sufficient relocations

\section{CHAPTER III}

Table 1: Median and range of home range and core use area size, defined by the area in $\mathrm{km}^{2}$ of the $95 \%$ and $50 \%$ utilization distributions, respectively, and mean and standard deviation (SD) of Brownian motion variance, an indicator of movement activity, across seasons and breeding period for American alligators (Alligator mississippiensis) in Water Conservation Area 3, Florida, USA tracked using satellite telemetry (2014-2015) for which there were sufficient relocations

Table 2: Percent composition of the study area, percent mean and standard deviation (SD) of home range, defined by the area of the $95 \%$ utilization distribution, and relocations, and mean and SD of Brownian motion variance, an indicator of movement activity, by habitat type for American alligators (Alligator mississippiensis) in Water Conservation Area 3, Florida, USA tracked using satellite telemetry (2014-2015) for which there were sufficient relocations

\section{CHAPTER IV}

Table 1: Repeated-measures analysis of variance of water-column total phosphorus. Sampling was performed in marsh, near-pond, and pond habitats in ten sites in Taylor Slough and Shark River Slough in the 2018 wet and 2019 dry seasons. Seasonal models were run separately because we were unable to collect dry season near-pond samples

Table 2: Repeated-measures analysis of variance of floc total phosphorus. Sampling 
was performed in marsh, near-pond, and pond habitats at ten sites in Taylor Slough and Shark River Slough in the 2018 wet season

Table 3: Estimated marginal least-squares means of floc total phosphorus compared among habitats. Sampling was performed in marsh, near-pond, and pond habitats at ten sites in Taylor Slough and Shark River Slough in the 2018 wet season.

Table 4: Presence of aquatic plants sampled in marsh, near-pond, and pond habitats at ten sites in Taylor Slough and Shark River Slough in the 2018 wet and 2019 dry seasons. Presence is expressed as the proportion of visits to each habitat at ten sites across two seasons

Table 5: Repeated-measures analysis of variance of richness of plant communities. Sampling was performed in marsh, near-pond, and pond habitats at ten sites in Taylor Slough and Shark River Slough in the 2018 wet and 2019 dry seasons

Table 6: Permutational multivariate analysis of variance results from Morisita-Horn dissimilarity matrix of plant communities. Sampling was performed in marsh, near-pond, and pond habitats at ten sites in Taylor Slough and Shark River Slough in the 2018 wet and 2019 dry seasons

Table 7: Relative abundance of benthic invertebrates sampled in marsh, near-pond, and pond habitats at ten sites in Taylor Slough and Shark River Slough in the 2018 wet and 2019 dry seasons

Table 8: Repeated-measures analysis of variance of richness of benthic invertebrate communities. Funnel trap sampling was performed in marsh, near-pond, and pond habitats at ten sites in Taylor Slough and Shark River Slough in the 2018 wet and 2019 dry seasons

Table 9: Estimated marginal least-squares means of richness of benthic invertebrate community for the interaction of season and habitat. Funnel trap sampling was performed in marsh, near-pond, and pond habitats at ten sites in Taylor Slough and Shark River Slough in the 2018 wet and 2019 dry seasons

Table 10: Permutational multivariate analysis of variance results from Morisita-Horn dissimilarity matrix of benthic invertebrate communities. Funnel trap sampling was performed in marsh, near-pond, and pond habitats at ten sites in Taylor Slough and Shark River Slough in the 2018 wet and 2019 dry seasons

Table 11: Count by taxa of aquatic consumers sampled in marsh, near-pond, and pond habitats at ten sites in Taylor Slough and Shark River Slough in the 2018 wet and 2019 dry seasons. Sampling was performed using throw traps, unbaited minnow traps, and drift fences 
Table 12: Repeated-measures analysis of variance of richness of aquatic consumer communities from throw trap, minnow trap, and drift fence sampling performed in marsh, near-pond, and pond habitats at ten sites in Taylor Slough and Shark River Slough in the 2018 wet and 2019 dry seasons. Datasets were parsed to account for unequal sampling

Table 13: Estimated marginal least-squares means of aquatic consumer richness for significant effects from throw trap, minnow trap, and drift fence sampling performed in marsh, near-pond, and pond habitats at ten sites in Taylor Slough and Shark River Slough in the 2018 wet and 2019 dry seasons

Table 14: Permutational multivariate analysis of variance results from Morisita-Horn dissimilarity matrix of aquatic consumer communities from throw trap, minnow trap, and drift fence sampling performed in marsh, near-pond, and pond habitats at ten sites in Taylor Slough and Shark River Slough in the 2018 wet and 2019 dry seasons

\section{CHAPTER V}

Table 1: Source assignment of fatty acid biomarkers used in this study (modified from Belicka et al. 2012). We present fatty acids as $\mathrm{A}: \mathrm{B} \omega \mathrm{C}$, where $\mathrm{A}$ describes the number of carbon atoms, $\mathrm{B}$ is the number of double bonds, and $\mathrm{C}$, if needed, gives the location of the first double bond from the methyl end. We abbreviated iso- $(i)$, anteiso- $(a)$, and methyl $(\mathrm{Me})$

Table 2: Multivariate analysis of variance for arcsine-square-root transformed proportion of total of fatty acids of flocculent detrital material grouped by source (algal, bacterial, plant) collected at marsh, near-pond, and pond habitats at ten sites in Taylor Slough and Shark River Slough in the 2018 wet and 2019 dry seasons

Table 3: Univariate analysis of variance for arcsine-square-root transformed proportion of total of fatty acids grouped by source (algal, bacterial, plant) in flocculent detrital material among habitats at ten sites in Taylor Slough and Shark River Slough in the 2018 wet and 2019 dry seasons

Table 4: Post-hoc Tukey's honest significance differences for arcsine-square-root transformed proportion of total of fatty acids grouped by source (algal, bacterial, plant) in flocculent detrital material among habitats at ten sites in Taylor Slough and Shark River Slough in the 2018 wet and 2019 dry seasons

Table 5: Analysis of variance for sum total of essential fatty acids, LIN, and the ratio of saturated and unsaturated to poly-unsaturated fatty acids all as a percent total of fatty acids of flocculent detrital material grouped by source (algal, bacterial, plant) collected at marsh, near-pond, and pond habitats at ten sites in Taylor Slough and 
Shark River Slough in the 2018 wet and 2019 dry seasons. The dry season error structure was singular because of unequal sampling; addition of random error did not affect significance conclusions. The ratio of (SAFA + MUFA):PUFA was $\log -10(x+1)$ transformed

Table 6: Multivariate analysis of variance for arcsine-square-root transformed proportion of total of fatty acids of periphyton mats grouped by source (algal, bacterial, plant) collected at marsh habitats at ten sites in Taylor Slough and Shark River Slough in the 2018 wet and 2019 dry seasons

Table 7: Univariate analysis of variance for arcsine-square-root transformed proportion of total of fatty acids grouped by source (algal, bacterial, plant) in periphyton mats in marsh habitats at ten sites in Taylor Slough and Shark River Slough in the 2018 wet and 2019 dry seasons

Table 8: Analysis of variance for sum total of essential fatty acids, LIN, ARA, and the ratio of saturated and unsaturated to poly-unsaturated fatty acids all as a percent total of fatty acids of periphyton mats grouped by source (algal, bacterial, plant) collected at marsh habitats at ten sites in Taylor Slough and Shark River Slough in the 2018 wet and 2019 dry seasons. The ratio of (SAFA + MUFA):PUFA was $\log -10(x+1)$ transformed 


\section{LIST OF FIGURES}

FIGURE

PAGE

\section{CHAPTER II}

Figure 1: Map of Shark River Estuary, Florida, USA 43

Figure 2: Home range size, defined by the area of the $95 \%$ utilization distribution, across the wet season, dry season, and breeding period for male, female, river, and marsh satellite-tracked American alligators (Alligator mississippiensis) in Shark River Estuary, Florida, USA (2013-2016)

Figure 3: Home range size, defined by the area of the $95 \%$ utilization distribution, and mean movement activity (Brownian motion variance) compared across satellitetracked American alligators (Alligator mississippiensis) of different total lengths and body conditions in Shark River Estuary, Florida, USA (2013-2016)....

Figure 4: Movement activity (Brownian motion variance) of male, female, river, and marsh satellite-tracked American alligators (Alligator mississippiensis) compared across wet and dry seasons and breeding periods in Shark River Estuary, Florida, USA (2013-2016).

\section{CHAPTER III}

Figure 1: Map of Water Conservation Area 3, Florida, USA

Figure 2: Home range size, defined by the area of the $95 \%$ utilization distribution, across the wet season, dry season, and breeding period for both male and female satellite-tracked American alligators (Alligator mississippiensis) in Water Conservation Area 3, Florida, USA (2014-2015).

Figure 3: Home range size, defined by the area of the $95 \%$ utilization distribution, and mean movement activity (Brownian motion variance) compared across satellitetracked American alligators (Alligator mississippiensis) of different total lengths and body conditions in Water Conservation Area 3, Florida, USA (2014-2015)

Figure 4: Movement activity (Brownian motion variance) of satellite-tracked American alligators (Alligator mississippiensis) in the 30-days before and the first 30-days during an experimental water release in Water Conservation Area 3, Florida, USA from 4 November 2014 to 29 January 2015 
Figure 5: Movement activity (Brownian motion variance) of male ("M") and female ("F") satellite-tracked American alligators (Alligator mississippiensis) compared across wet and dry seasons and breeding and non-breeding periods in Water Conservation Area 3, Florida, USA (2014-2015)

Figure 6: Carbon and nitrogen stable isotope values for blood plasma and scute tissues of satellite-tracked American alligators (Alligator mississippiensis) compared across males and females caught in both the wet and dry seasons in Water Conservation Area 3, Florida, USA (2014-2015)

Figure 7: Population-level habitat selection ratios of satellite-tracked American alligators (Alligator mississippiensis) in Water Conservation Area 3, Florida, USA (2014-2015) at the scale of selecting home ranges within the study area and at the scale of selecting patches within home ranges. Habitats are abbreviated as "CA" is canal, "SG" is sawgrass marsh, "WV" is woody vegetation, "GP" is spikerush marsh, and " $\mathrm{EV}$ " is emergent aquatic vegetation 98

\section{CHAPTER IV}

Figure 1: Alligator pond sites in Taylor Slough and Shark River Slough, Everglades, Florida, USA in the 2018 wet and 2019 dry seasons

Figure 2: Water-column total phosphorus for marsh, near-pond, and pond habitats at ten sites in Taylor Slough and Shark River Slough in the 2018 wet and 2019 dry seasons. Wet season site MDB for the near-pond was an extreme outlier at 30.85 $\mu \mathrm{mol} / \mathrm{L}$ and was not plotted. The near-pond habitat was not sampled during the dry season because of marsh drydown

Figure 3: Floc total phosphorus for marsh, near-pond, and pond habitats at ten sites in Taylor Slough and Shark River Slough in the 2018 wet season

Figure 4: Non-metric multidimensional scaling biplot revealing plant compositional similarity among marsh, near-pond, and pond habitats. Sampling was performed at ten sites in Taylor Slough (represented by a circle) and Shark River Slough (square) in the 2018 wet (green) and 2019 dry (brown) seasons. Ellipses represent 1 standard deviation and are outlined and shaded to represent habitats: pond (blue), near-pond (green), and marsh (brown). Generally, taxa are abbreviated in the plot as the first three letters of genus and species. Taxa are abbreviated in the plot as the first three letters of genus followed by first three letters of species.

Figure 5: Rarefaction curves for benthic invertebrate communities from funnel trap sampling performed in marsh, near-pond, and pond habitats at ten sites in Taylor Slough and Shark River Slough in the 2018 wet and 2019 dry seasons 
Figure 6: Dominance-diversity curves for mean CPUE (1,000 mL) of benthic invertebrate communities from funnel trap sampling performed in marsh, near-pond, and pond habitats at ten sites in Taylor Slough and Shark River Slough in the 2018 wet and 2019 dry seasons. Taxa are abbreviated in the plot as the first four letters: Copepoda, Ostracoda, Mollusca, Cladocera, Amphipoda, Diptera, Ephemeroptera, Nematoda, Platyhelminthes, Hemiptera, Odonata, and Trombidiformes

Figure 7: Non-metric multidimensional scaling biplot revealing benthic invertebrate compositional similarity among marsh, near-pond, and pond habitats. Funnel trap sampling was performed at ten sites in Taylor Slough (represented by a circle) and Shark River Slough (square) in the 2018 wet (green) and 2019 dry (brown) seasons. Ellipses represent 1 standard deviation and are outlined and shaded to represent habitats: pond (blue), near-pond (green), and marsh (brown). Generally, taxa are abbreviated in the plot as the first three letters of genus and species. Taxa are abbreviated in the plot as the first four letters: Copepoda, Ostracoda, Mollusca, Cladocera, Amphipoda, Diptera, Ephemeroptera, Nematoda, Platyhelminthes, Hemiptera, Odonata, and HYDR = Trombidiformes

Figure 8: Rarefaction curves of aquatic consumer communities from throw trap, minnow trap, and drift fence sampling performed in marsh, near-pond, and pond habitats at ten sites in Taylor Slough and Shark River Slough in the 2018 wet and 2019 dry seasons

Figure 9: Dominance-diversity curves for mean relative abundance of aquatic consumer communities from throw trap, minnow trap, and drift fence sampling performed in marsh, near-pond, and pond habitats at ten sites in Taylor Slough and Shark River Slough in the 2018 wet and 2019 dry seasons. Generally, taxa are abbreviated in the plot as the first three letters of genus and species

Figure 10: Dominance-diversity curves for mean catch per unit effort $\left(3 \times 1 \mathrm{~m}^{3}\right)$ of aquatic consumer communities from throw trap sampling performed in marsh, near-pond, and pond habitats at ten sites in Taylor Slough and Shark River Slough in the 2018 wet and 2019 dry seasons. Generally, taxa are abbreviated in the plot as the first three letters of genus and species

Figure 11: Dominance-diversity curves for mean catch per unit effort of aquatic consumer communities from un-baited minnow trap sampling performed in marsh, near-pond, and pond habitats at ten sites in Taylor Slough and Shark River Slough in the 2018 wet and 2019 dry seasons. Generally, taxa are abbreviated in the plot as the first three letters of genus and species

Figure 12: Dominance-diversity curves for mean catch per unit effort of aquatic consumer communities from drift fence sampling performed in marsh and near-pond habitats at ten sites in Taylor Slough and Shark River Slough in the 2018 wet and 
2019 dry seasons. Generally, taxa are abbreviated in the plot as the first three letters of genus and species.

Figure 13: Non-metric multidimensional scaling biplot revealing aquatic consumer compositional similarity among marsh, near-pond, and pond habitats from throw trap, minnow trap, and drift fence sampling performed at five sites in Shark River Slough in the 2018 wet (green) and 2019 dry seasons (brown). Ellipses represent 1 standard deviation and are outlined and shaded to represent habitats: pond (blue), near-pond (green), and marsh (brown). Generally, taxa are abbreviated in the plot as the first three letters of genus and species

\section{CHAPTER V}

Figure 1: Alligator pond sites in Taylor Slough and Shark River Slough, Everglades,

Florida, USA in the 2018 wet and 2019 dry seasons

Figure 2: Mean percent total of fatty acids for flocculent detrital material grouped by source (algal, bacterial, plant) collected at marsh, near-pond, and pond habitats at ten sites in Taylor Slough and Shark River Slough in the 2018 wet and 2019 dry seasons. Error bars denote 1 standard deviation from the mean. For each source, analysis of variance (ANOVA) and post-hoc Tukey's Honest Significant Differences (HSD) compared differences in means across habitats evaluated at $\alpha=0.05$

Figure 3: Mean percent total of fatty acids for periphyton mats grouped by source (algal, bacterial, plant) collected in marsh habitats at ten sites in Taylor Slough and Shark River Slough in the 2018 wet and 2019 dry seasons. Error bars denote 1 standard deviation from the mean

Figure 4: Mean percent total of fatty acids for consumers grouped by source (algal, bacterial, plant) collected at marsh and pond habitats at ten sites in Taylor Slough and Shark River Slough in the 2018 wet and 2019 dry seasons. Error bars denote 1 standard deviation from the mean. Species were abbreviated by the first three letters of genus and species: GAMHOL = Gambusia holbrooki (Eastern Mosquitofish), LUCGOO = Lucania goodei (Bluefin Killifish), and PALPAL = Palaemonetes paludosus (grass shrimp)

\section{CHAPTER VI}

Figure 1: Conceptual model of the effects of predation and engineering on community structure and ecosystem function 


\section{CHAPTER I}

\section{GENERAL INTRODUCTION}


A long-standing debate in food web ecology is the extent to which communities and ecosystems are structured from the bottom-up or from the top-down. Empirical and mathematical evidence supports the idea that primary productivity impacts plant biomass which controls the biomass of consumers (bottom-up) as well as that predators control herbivores and thus release plants from herbivory (top-down) (reviewed in Matson and Hunter 1992). It is clear that both of these pressures serve to organize food webs (Oksanen et al. 1981). What is less understood is when each form of control is more or less important.

The well-recognized ability of animals to influence nutrient limitation and habitat for basal autotrophic resources is often ignored in understanding top-down and bottom-up forcing. There are two major themes in the research of animal-mediated bottom up effects on food webs: 1) effects of nutrient translocation and recycling including direct impacts and indirect consequences of altering behavior of prey that serve as nutrient vectors (reviewed in Polis et al. 1997; Schmitz et al. 2010); and 2) effects from physical ecosystem engineering (reviewed in Sanders et al. 2014). Both theoretically and empirically, the interaction of the roles of predator and engineer have been poorly studied and we know little about the resulting net effects on food-web structure and function (but see Sanders and van Veen 2011).

Herein, I investigate the special case of a predator acting as an engineer and their effects on community structure and ecosystem function. The iconic American alligator (Alligator mississippiensis) of the oligotrophic Everglades is an excellent model system to study this ecological phenomenon. The alligator is an abundant predator in aquatic 
ecosystems throughout the southeastern United States and is considered an opportunistic generalist (Delany and Abercrombie 1986, Rosenblatt et al. 2015). Alligators may affect nutrient cycling by facilitating nutrient transport across productivity gradients (Rosenblatt and Heithaus 2011) and the aquatic-terrestrial matrix (Subalusky et al. 2009) through cross-ecosystem movements. Alligators can also physically modify the environment, perhaps most significantly through their creation and maintenance of "alligator ponds" (Kushlan 1974, Campbell and Mazzotti 2004, Palmer and Mazzotti 2004). Engineering activities associated with these ponds may affect the affect establishment and recruitment of plant species (Palmer and Mazzotti 2004), distribution of aquatic fauna seeking refuge in the dry season (Kushlan 1974; Kushlan and Kushlan 1980), and result in altered biogeochemical cycling. For instance, by digging alligators may remobilize legacy phosphorus (P) stored in sediment. Also, animals using the ponds, including the alligators themselves, may transport nutrients and organic matter from the surrounding marsh and concentrate it in the pond. These changes may be significant in a P-limited system like the freshwater Everglades where additions as small as 3-13 $\mu \mathrm{g} \mathrm{L} \mathrm{L}^{-1}$ can shift the basal resources of the food web from detrital- to algal-dominance (Noe et al. 2002, Childers 2006).

Animal movement is an important link to how consumers impact bottom-up processes and has implications for grasping their roles as predators and ecosystem engineers. Documenting and understanding movement patterns and behaviors can reveal the scale of impact that consumers have on bottom-up forcing. In Chapter 2, I start by studying the patterns and drivers of movement for alligators in an oligotrophic freshwater marsh to estuary transition. Here, using satellite telemetry data coupled with 
environmental data, I investigate the potential of cross-ecosystem movement and individual specialization in movement behavior. Understanding the movement patterns and animal-mediated exchange and transport of nutrients and organic matter across distinct habitat boundaries is one mechanism for consumers to affect bottom-up processes. Next in Chapter 3, I focus on the drivers of movement of alligators in a managed freshwater marsh ecosystem particularly sensitive to ecosystem engineering effects of alligators. Specifically, I model the effects of a large-scale experimental water release on alligator movement and habitat use and determine overall rates of movement across space and time.

Through engineering and the movement of nutrients, animals impact bottom-up processes, which may result in changes in food-web structure and function. For Chapter 4, I investigate the possibility of nutrient enrichment at alligator-engineered ponds created by the maintenance and use of these ponds by aquatic fauna as a low-water refuge. I also use sampling of algal, plant, invertebrate, and fish communities to determine potential differences in community structure associated with ponds and engineering. Chapter 5 tests the hypothesis that alligator-engineered ponds have shifted ecosystem function towards increased primary production. In this chapter, I use fatty acid biomarkers to detect the origin of organic matter and the pathways of energy flow on basal food-web resources and three abundant Everglades freshwater consumers.

I conclude, in Chapter 6, by discussing the implications of my research for understanding the role of alligators in the Everglades and, more broadly, the importance of consumer-mediated effects on ecosystem processes. I end with future research 
directions that may yield developments in food web ecology and our understanding of predators beyond their roles in eating and scaring prey.

\section{Literature Cited}

Campbell, M. R., and F. J. Mazzotti. 2004. Characterization of natural and artificial alligator holes. Southeastern Naturalist 3:583-594.

Childers, D. L. 2006. A synthesis of long-term research by the Florida Coastal Everglades LTER Program. Hydrobiologia 569:531-544.

Delany, M.F. and C. Abercrombie. 1986. American alligator food habits in northcentral Florida. Journal of Wildlife Management 50:348-353.

Kushlan, J. A. 1974. Observations on the role of the American alligator in the Southern Flordia wetlands. Copeia 4:993-996.

Kushlan, J. A., and M. S. Kushlan. 1980. Everglades alligator nests: nesting sites for marsh reptiles. Copeia:1930-1932.

Matson, P. A., \& Hunter, M. D. (1992). Special feature: The relative contributions to topdown and bottom-up forces in population and community ecology. Ecology, 73(3), 723-723.

Noe, G. B., D. L. Childers, L. J. Scinto, A. L. Edwards, E. Gaiser, D. Lee, J. Trexler, and R. D. Jones. 2002. Short-term changes in phosphorus storage in an oligotrophic Everglades wetland ecosystem receiving experimental nutrient enrichment. Biogeochemistry 59:239-267.

Oksanen, L., Fretwell, S. D., Arruda, J., \& Niemela, P. (1981). Exploitation ecosystems in gradients of primary productivity. The American Naturalist, 118(2), 240-261.

Palmer, M. L., and F. J. Mazzotti. 2004. Structure of everglades alligator holes. Wetlands 24:115-122.

Polis, G. A., W. B. Anderson, and R. D. Holt. 1997. Toward an integration of landscape and food web ecology: the dynamics of spatially subsidized food webs. Annual Review of Ecology and Systematics 28:289-316.

Rosenblatt, A. E., and M. R. Heithaus. 2011. Does variation in movement tactics and trophic interactions among American alligators create habitat linkages? The Journal of Animal Ecology 80:786-798. 
Rosenblatt, A.E., J.C. Nifong, M.R. Heithaus, F.J. Mazzotti, M.S. Cherkiss, B.M. Jeffery, R.M. Elsey, R.A. Decker, B.R. Silliman, L.J. Guillette, R.H. Lowers, J.C. Larson. 2015. Factors affecting individual foraging specialization and diet stability across the range of a large "generalist" apex predator. Oecologia 178:5-16.

Sanders, D., C. G. Jones, E. Thébault, T. J. Bouma, T. van der Heide, J. van Belzen, and S. Barot. 2014. Integrating ecosystem engineering and food webs. Oikos 123:513524.

Sanders, D., \& van Veen, F. F. (2011). Ecosystem engineering and predation: the multitrophic impact of two ant species. Journal of Animal Ecology, 80(3), 569-576.

Schmitz, O. J., D. Hawlena, and G. C. Trussell. 2010. Predator control of ecosystem nutrient dynamics. Ecology Letters 13:1199-1209.

Subalusky, A. L., L. A. Fitzgerald, and L. L. Smith. 2009. Ontogenetic niche shifts in the American alligator establish functional connectivity between aquatic systems. Biological Conservation 142:1507-1514. 
CHAPTER II

INDIVIDUAL VARIATION AND ABIOTIC DRIVERS OF MOVEMENT AND HABITAT USE FOR AMERICAN ALLIGATORS IN A SUBTROPICAL ESTUARY 


\begin{abstract}
Understanding the drivers, scales, and variation in fundamental behavioral and ecological responses such as movement is important for accurate prediction in dynamic ecosystems. Complicating predictions is the potential for individual specialization in movement tactics and, consequentially, intra-population variation in their impacts on community- and ecosystem-level processes. We studied the correlates of movement and habitat use, as well as individual variation in these parameters, of American alligators in the Shark River Estuary of the Everglades, Florida, USA. The estuary exhibits a gradient of productivity from phosphorus-rich marine waters to oligotrophic freshwater marshes and experiences considerable variation in abiotic factors in time and space. We found that alligators used several different movement tactics throughout the estuary. Some animals exhibited commuting behavior by making regular trips from the mid-estuary to the coastal rivers or to the freshwater marshes. However, movements of animals tagged in the marsh transition zone were more sedentary than those tagged in the river. Beyond major differences between habitats, we observed larger ranges and higher movement activity for males compared to females. Across both sexes, movement activity peaked in the breeding period. We also found that activity was associated with several abiotic factors including temperature, water level, salinity, and moon phase but the overall effect was dependent upon an animal's general location in the estuary. Variation in movement behavior by alligators may manifest into differences in ecological roles of individuals within the population.
\end{abstract}




\section{Introduction}

Natural selection favors strategies that maximize fitness. Even within a population, there are ranges of both innate and learned behaviors that are successful for survival and reproduction (Komers 1997). Thus, grouping all individuals into the same behavioral category and examining average responses across populations may not fully capture ecological dynamics and the interaction of organisms (Bolnick et al. 2003).

Differences in animal behavior by sex, size, age, or individual-level phenotypic variation are well-established (Bolnick et al. 2003; Duffy 2010). These differences in behavioral traits can lead to dissimilarities in fitness including predation risk, reward potential of food resources, and even parasite susceptibility (Reale et al. 2007; Duffy 2010; Araujo et al. 2011). Individual variation can also scale-up to affect communities and ecosystem processes (Bolnick et al. 2011; Schreiber et al. 2011). Understanding variation in animal behavior, therefore, is important for revealing diverse ecological roles within and among individuals of the same population and populations of a single species.

In general, animals are assumed to occupy the minimum area needed to obtain the resources necessary to maximize fitness (Said and Servanty 2005). In addition, optimal foraging theory predicts that as the quality of a patch decreases, animals will increase activity, movements, and exploration to investigate other patches (Fretwell and Lucas 1970; Fretwell 1972). Both theoretically and empirically, the decision an animal makes about when and where to move, or not to move, involves many pieces of information. These choices are driven by internal state conditions (e.g., energy reserves, age, sex, individual specialization) and external factors including biotic interactions and abiotic conditions. For instance, external drivers of variation in movement tactics involve intra- 
specific competition, habitat complexity, and climatic variability (Bolnick et al. 2003; Svanbäck and Bolnick 2007). Movement ecology has had a paradigm shift centered on individual variation in movement strategies and has emphasized individual and Lagrangian approaches to modelling that account for these flexibilities in animal behavior (Nathan et al. 2008). Understanding the drivers and the context of which these factors are operating in is particularly important for revealing the ecological roles of abundant species or species with many or strong trophic interactions.

Large-bodied abundant predators can exert considerable effects on ecosystems (e.g., Estes et al. 2011, Schmitz et al. 2010) making studies of their movement ecology and patterns of individual behavioral differences important. Crocodilians are dominant predators in numerous tropical and subtropical freshwater and estuarine ecosystems. The American alligator is widely regarded as a dietary generalist with potential top-down effects (Nifong and Silliman 2013; Rosenblatt et al. 2015). Alligators have been studied as physical ecosystem engineers (Kushlan 1974) and may be important mobile vectors of nutrients between terrestrial and aquatic systems and among aquatic habitats (Rosenblatt and Heithaus 2011; Subalusky et al. 2009). Alligators are found in diverse aquatic habitats in the Southeastern United States including coastal estuaries, freshwater marshes, swamps, inland reservoirs and lakes, and small stream drainages. Generally, crocodilian movements are associated with thermoregulation, defense of territory, mate acquisition, and foraging (Lang 1987). Individual variation in movement tactics of alligators has been documented in some systems and is associated with variation in trophic interactions (Rosenblatt and Heithaus 2011), habitat complexity (Rosenblatt et al. 2013), and possibly responses to extreme weather (Strickland et al. 2020). Several studies document alligator 
movement between distinct habitats in estuaries particularly marine habitats and estuarine rivers (e.g., Rosenblatt and Heithaus 2011; Fujisaki et al. 2014; Nifong and Silliman 2017). However, we have a limited understanding about the patterns and drivers of movement across the habitats and conditions alligators face in estuaries.

The Florida coastal Everglades is a dynamic estuarine ecosystem with major seasonal and interannual fluctuations in abiotic conditions including salinity, temperature, and rainfall (Childers 2006). For example, more than $60 \%$ of the annual rainfall occurs in four months (June to September) of the wet season (Romigh et al. 2006). The estuaries of the Everglades span multiple distinct habitats including freshwater marshes and downstream marine habitats. The variability in conditions and multiple disparate habitats make this an excellent system to study alligator habitat use and movement. In addition, major environmental and hydrological restoration efforts are underway in the Florida Everglades and continue to change average abiotic conditions and their variability (Sklar et al. 2005). Understanding the effects of state and external factors on alligator behavior may help us predict the impact of future restoration efforts and the ecological roles of alligators in coastal estuaries. We used satellite telemetry and individual-based movement models to quantify movements and ranges of alligators across a range of environmental conditions in space (from freshwater marshes to marine coastlines) and time (e.g. seasonal variation). We investigated the potential role of both state and abiotic factors in shaping individual differences in movement behavior. 


\section{Methods}

Study area

Alligators were tagged in the Shark River Estuary (SRE) and Slough of Everglades National Park, USA, (Figure 1) which serves as one of the main conduits for freshwater to drain in the Gulf of Mexico (Rudnick et al. 1999). The SRE is a braided stream system extending more than $30 \mathrm{~km}$ from the Gulf of Mexico dominated by red mangroves (Rhizophora mangle) (Childers 2006). In the estuary, heavy rainfall during the wet season (roughly May-October) leads to lower salinity than the dry season (roughly November-April) (Romigh et al. 2006). The estuary is generally oligotrophic with marine phosphorous driving high productivity close to the Gulf of Mexico and declining productivity upstream (Childers 2006). We divided the Shark River Estuary into four zones based on ecologically distinct habitats across the productivity gradient: euryhaline coastal rivers (i.e., Shark River and Harney River), mesohaline embayment (i.e., Tarpon Bay), oligohaline upper river network (i.e., Rookery Branch), and freshwater marsh (see Massie et al. 2019; Matich and Heithaus 2012). Alligators can and do move throughout these habitats within the estuary (Rosenblatt and Heithaus 2011). The downstream coastal rivers and islands are inhabited by marine and estuarine species (Childers 2006). The habitat is characterized by deep and wide channels and is influenced by tides causing fluctuations in depths which range from 3 to $5 \mathrm{~m}$ and changes in salinity from $<10 \mathrm{ppt}$ in the wet season and $>30 \mathrm{ppt}$ in the dry season (Childers 2006; Rosenblatt and Heithaus 2011). The shallow (depths $<2 \mathrm{~m}$ ) embayment is lined with a soft mud bottom and is inhabited by estuarine species (Childers 2006; Massie et al. 2019). The upriver portion is a network of narrow rock- and mud-bottomed streams bordered by 
sawgrass (Cladium spp.) and red mangroves (Rhizophora mangle) (Childers 2006;

Boucek and Rehage 2013). Upriver has minimal tidal influence and is home to primarily freshwater communities with some estuarine species (Boucek and Rehage 2013). At the onset of marsh drydown during the dry season, a pulsed subsidy of cyprinodontoid, invertebrate, and sunfishes move into the upper river network (Boucek and Rehage 2013). In the freshwater marsh transition zone, organic peat soils overlay limestone bedrock and marsh water levels fluctuate seasonally with shorter hydroperiod areas dominated by sawgrass and longer hydroperiod areas predominantly spikerushes (Eleocharis spp.) (Daoust and Childers 1999).

\section{Alligator capture and tagging}

High-powered spotlights were used at night to find alligators by looking for reflective eyeshine. Alligators were captured using a pole and snare technique. For each captured animal, we determined sex from cloaca examination (Chabreck 1963) and measured total length, tail girth, head length, and snout-vent length to the nearest $\mathrm{cm}$. We also measured mass using a spring scale to the nearest $100 \mathrm{~g}$. We attached a satellite transmitter (Spot 5; Wildlife Computers; Redmond, Washington, USA) to the nuchal scutes of each sexually mature alligator following the methods of Brien et al. (2010) and

Strickland et al. (Ch. 1). For satellite tracking, we used the Argos Low Earth Orbit global satellite-based location and data collection system. Tag battery life was estimated to be between 400-540 days using programming settings of a maximum of 250 locations per day and a repetition rate of 44.5-89.5 seconds. Argos position estimates are grouped into six location classes as a function of accuracy: class 3 (accurate within $250 \mathrm{~m}$ ), class 2 
(250 to $500 \mathrm{~m}$ ), class 1 (500 to $1,500 \mathrm{~m}$ ), class 0 (more than 1,500 m), and classes A and B (unbounded accuracy estimation). We used the Douglas filtering method, retained only class 3 and 2 locations, and removed duplicate locations (see Strickland Ch. 1). Animals with fewer than 40 total filtered relocations were omitted. In the filtered dataset, nearly all locations (>95\%) were obtained between sunset and sunrise; thus, we removed daytime locations from future analyses to avoid bias.

We released the animals at their capture location. We calculated Fulton's body condition factor $(\mathrm{K})$ using mass $(\mathrm{M})$ and snout-vent length $(\mathrm{SVL})$ as $\mathrm{K}=\mathrm{M} / \mathrm{SVL}^{3} \times 10^{5}$ (Brandt et al. 2016). Alligators were classified as being in poor $(\mathrm{K} \leq 1.95)$, fair $(1.95<\mathrm{K}$ $\leq 2.10)$, good $(2.10<\mathrm{K} \leq 2.27)$, or excellent condition $(\mathrm{K}>2.27)$ (Brandt et al. 2016; Mazzotti et al. 2009). When assessing correlations between body size and body condition metrics, we used Spearman's rank coefficient. We used exact Wilcoxon rank sum tests when comparing total length and body condition between males and females and between alligators captured in the estuarine river and the freshwater marsh due to low sample sizes in each group.

\section{Environmental data}

We obtained daily weather data including precipitation and air temperature through National Oceanic and Atmospheric Administration's National Centers for Environmental Information data access web portal (NOAA 2019). We selected the Royal Palm Ranger Station, which was the closest weather station to our study site. We then used the "suncalc" and "maptools" R packages to obtain proportion of the moon illuminated and solar position by hour (Thierurnmel and Elmarchraoui 2019; Bivand and 
Lewin-Koh 2019). We downloaded hydrological data from the United States Geological Survey/National Park Service Everglades Depth Estimation Network database (USGS 2019). We used Site Gunboat Island for relocations from the coast to the mid-estuary and Site Bottle Creek for relocations in the mid-estuary to upstream marsh habitat (USGS 2019).

Movement between habitats

We divided the estuary into four broad habitats as defined by salinity and habitat structure (see Study Area). Individuals travelling between two or more zones were separated into "commuters" and those remaining in one zone were classified as "resident" animals (Rosenblatt and Heithaus 2011). For each commuter, we determined the timing of each zone change and estimated the duration of time spent within one zone before moving to another. We summed all durations by habitat and calculated percent time spent in one zone compared to the total days tracked. For descriptions of commutes, we excluded durations for the first initial zone change and the last one given that these are bounded by capture and tag/battery failure. We also calculated the step length, or distance between each successive location.

Movement model and space use estimator

To study the movement patterns and space use of individual animals, we used dynamic Brownian bridge movement models in the "move" R package (Kranstauber et al. 2019). These models use time, angle, and distance between locations to interpolate intermediate points, calculate motion variances along a path, and produce a utilization 
distribution (UD) (Fieberg and Kochanny 2005; Kranstauber et al. 2012). The models allowed us to incorporate the estimated maximum error of each location equivalent to its assigned Argos location class [i.e., class $3(250 \mathrm{~m})$ and class $2(500 \mathrm{~m})]$. We used the $95 \%$ UD contour area to approximate the overall home range of the animal and the $50 \%$ UD contour area to define its area of core use (Kei et al. 2010; Said and Servanty 2005). Multi-annual, seasonal, and breeding period dynamic Brownian bridge movement models and UD estimations were only performed for animals with 40 or more locations within the timeframe. We defined the breeding period as courtship and mating only which occurs April 1-June 1 each year (Mazzotti and Brandt 1994). To evaluate the correlation between total length and range sizes as well as body condition and range sizes, we used Spearman's rank coefficient test. We also used exact Wilcoxon rank sum tests to compare overall, seasonal, and breeding range sizes between males and females and between capture areas. We used a paired two-sample Wilcoxon test to compare seasonal and breeding period range sizes across animals.

These models also estimate motion variance along the pathway where changes indicate changes in an animal's activity and behavioral state (i.e., high values imply increased activity and/or irregular movement paths and low values are coupled with decreased activity and/or regular paths) (Kranstauber et al. 2012; Byrne et al. 2014). We compared female and male movement activity along with breeding period and seasons using an exact Wilcoxon rank test. We used Spearman's rank coefficient to test the correlation of movement activity to body condition and body size. For marsh and riverine animals, we separately accessed the relationship of movement activity to site-specific water level using Spearman's rank correlation. For the riverine animals only, we 
determined the relationship of movement activity and salinity. We performed all statistical analyses using R (Mac version 3.6.1; R Foundation for Statistical Computing; Vienna, Austria). We reported means with \pm 1 standard deviation (SD).

\section{Results}

We fitted satellite tags to alligators ( $n=15$ total $)$ in the Shark River Estuary and Slough of Everglades National Park. Animals caught in the eastern portion of the estuary or Slough (hereafter, "marsh) and animals caught in the mid-estuary (hereafter, "river") were separated for some analyses. The first group of animals were tagged in January 2013 and the last transmission occurred in January 2016. The final filtered dataset for movement analyses included 3,068 locations of 12 animals with a mean of $256 \pm 105$ locations per animal $($ range $=62-401)($ Table A1). Average daily fix rate (calculated as number of days with a successful relocation divided by total number of days within the tracking period) for all tagged animals was $45 \pm 9 \%$.

Body size measurements were highly correlated [all Spearman's rho $(\mathrm{P})>0.79$ ];

thus, we used only total length as a proxy for body size in subsequent analyses. Alligator total length averaged $2.4 \mathrm{~m}$ and ranged from 1.9 to $3.0 \mathrm{~m}$. Males $(n=12)$ had a mean total length of $2.5 \pm 0.3 \mathrm{~m}$ whereas females $(n=3)$ had a smaller average length of $2.1 \pm$ $0.2 \mathrm{~m}(\mathrm{~W}=32, p=0.02)$. Fulton's condition factor ranged from 1.66 to 2.48 with a mean of 2.14 . About $17 \%$ of the tagged animals were in poor condition, $33 \%$ in fair, $25 \%$ in good, and 25\% in excellent body condition. Fulton's condition factor was not correlated with total length ( $\mathrm{P}=0.02, S=550, p=0.95)$. We found no difference in the body 
conditions of alligators caught in the marsh $(n=7)$ versus the estuary $(n=8)(\mathrm{W}=19, p$ $=0.34)$ or between males and females $(\mathrm{W}=26, p=0.30)$.

\section{Movement between habitats}

Six, or half, of the animals were residents of one zone. Five individuals were exclusive residents of the freshwater marsh including our two tagged female alligators. One animal (129517) was an exclusive resident of Tarpon Bay over the 343 days it was tracked. Our other six animals exhibited movement between two or more zones (Table 1). Three individuals moved across the mid-estuary embayment to the upstream network. Individual 129519 spent almost all of its time in Rookery Branch (99\%) and made two short ( $<1$ day) trips (9.9 and $5.1 \mathrm{~km}$ round trip) into Tarpon Bay (1\%) in early April and late May, respectively. Animal 133375 moved from mid Tarpon Bay (where it spent $80 \%$ of its time) beyond the northeastern portion of Rookery Branch (1\%) and into the freshwater marsh (19\%). After 131 days in Tarpon Bay after capture, this animal made four short trips (1.2 \pm 0.9 days) to Rookery Branch starting in mid-March to midMay. The first three trips averaged $3.0 \pm 0.8 \mathrm{~km}$ round trip, but on the fourth trip and longest distance trip, the animal moved $3.6 \mathrm{~km}$ one way to the eastern portion of Rookery Branch. The animal immediately continued moving into the freshwater marsh another 1.6 $\mathrm{km}$ staying for one month before moving $3.6 \mathrm{~km}$ immediately back to Tarpon Bay. After four days the animal then moved $3.8 \mathrm{~km}$ back to the marsh for another 38 days before finally moving $4.2 \mathrm{~km}$ back to Tarpon Bay for the remaining 98 days of tracking. Animal 129516 straddled our demarcation of Tarpon Bay (46\%) and Rookery Branch (54\%). Interestingly, three days after capture in late October the animal moved over $3 \mathrm{~km}$ 
(straight line distance) in less than 23 hours across multiple habitat types including dense mangrove forest and shallow open bay. The animal moved ten times (round trip) between Tarpon Bay and Rookery Branch with an average trip duration of $4.8 \pm 4.7$ days in Tarpon Bay and $5.4 \pm 10.5$ days in Rookery Branch. Round trip distances averaged $1.9 \pm$ $0.7 \mathrm{~km}$, but several of the one-way trips were less than the error associated with our tags. One animal moved from the upstream network to the marsh. Animal 146674 moved between Rookery Branch and the freshwater marsh spending $83 \%$ of its time in Rookery Branch and $17 \%$ in the freshwater marsh. The animal was the only one of six individuals caught in the marsh that traveled downstream into other estuary habitats. After nearly 40 days in Rookery Branch post-capture, the animal made three moves to the freshwater marsh lasting $4.9 \pm 6.1$ days from mid-March to mid-April. The first-round trip move was long $(10.3 \mathrm{~km})$ compared to the next two $(1.2$ and $1.9 \mathrm{~km})$. In mid-April the animal moved $1.5 \mathrm{~km}$ to the freshwater marsh and remained for 45 days before returning $1.0 \mathrm{~km}$ back to Rookery Branch for the remaining 247 days of tracking. Lastly, two individuals, 123531 and 123532, made regular movements into the downstream coastal river areas. Animal 123531 spent $57 \%$ of its time in Shark River including a short move south outside of the river into a shallow embayment, $2 \%$ in Tarpon Bay, and $41 \%$ in freshwater marsh habitat. After its capture in Shark River in February 2013, it immediately moved upstream to Tarpon Bay $2.6 \mathrm{~km}$ and then $2.5 \mathrm{~km}$ back to Shark River. Over a nine-day period in early February 2013 (within which we did not get a single detection), the animal moved $14.8 \mathrm{~km}$ straight-line distance to the freshwater marsh where it spent 138 days before moving $14.4 \mathrm{~km}$ back to Shark River in July. The animal also made two more trips upstream to Tarpon Bay lasting a few hours 
(3.1 $\mathrm{km}$ round trip) and 6 days $(4.4 \mathrm{~km})$ in late July and early December 2013, respectively. Between these two trips, the animal made a seven-day $21.9 \mathrm{~km}$ round trip to Whitewater Bay, an embayment south of the Shark River. Animal 123532 spent $84 \%$ of its time in the coastal rivers and $16 \%$ in Tarpon Bay. The male only had two zone changes. It was caught in the Harney River and moved $1.9 \mathrm{~km}$ upstream to Tarpon Bay staying 67 days before moving back downstream $4.2 \mathrm{~km}$ in the dry to wet season transition period. The animal resided in the Harney River for almost a year (332 days) before the last transmission.

\section{Space use}

Mean home range size was $34.2 \pm 50.9 \mathrm{~km}^{2}$ (range $=4.6-190.5 \mathrm{~km}^{2}$ ) and mean core use area was $2.5 \pm 3.7 \mathrm{~km}^{2}\left(\right.$ range $\left.=0.5-14.0 \mathrm{~km}^{2}\right)$ (Table 2). Animals 123532 , 129519, and 133375 all had $95 \%$ UD areas that were more than double the size of other

animals. However, animal 123531 had the largest 95\% UD area of all. Its range was more than three times the size of these three animals and more than ten times the size of the other animals. Two other commuters, animals 146674 and 129516, had range sizes similar to some residents. Overall, animals residing primarily in the freshwater marsh area of the estuary had almost $80 \%$ smaller ranges than those in the river channels of Shark River (home range, $\mathrm{W}=34, p<0.01$; core use, $\mathrm{W}=31, p=0.02$ ). Marsh animals had home ranges averaging $12.2 \pm 6.6 \mathrm{~km}^{2}$ compared to riverine animals where mean home range was $56.2 \pm 67.1 \mathrm{~km}^{2}$ (Figure 2). The marsh animals also had smaller home ranges in the breeding period $(\mathrm{W}=22, \mathrm{p}=0.03)$ and wet season $(\mathrm{W}=25, \mathrm{p}<0.01)$ but 
not the dry season $(\mathrm{W}=24, \mathrm{p}=0.39)$ compared to riverine animals (Figure 2$)$. These relationships hold even when removing riverine animal 123531.

Male alligators had larger 95\% UD areas averaging $39.6 \pm 54.6 \mathrm{~km}^{2}$ (Figure 2; W $=20, p=0.02$ ), than females averaging $7.3 \pm 3.9 \mathrm{~km}^{2}$, but we did not detect a difference in $50 \% \mathrm{UD}$ areas $(\mathrm{W}=17, p=0.18)$. Males still had larger home ranges than females even after removing the four commuters $(\mathrm{W}=12, p=0.04)$. However, when only looking at males in the marsh compared to the two females which were only captured in the marsh, there was no difference $(\mathrm{W}=8, p=0.13)$. There was no difference between sexes for wet season home range $(\mathrm{W}=15, p=0.09)$, wet season core area $(\mathrm{W}=12, p=$ $0.40)$, dry season home range $(\mathrm{W}=19, p=0.06)$, dry season core area $(\mathrm{W}=16, p=$ $0.27)$, breeding period home range $(\mathrm{W}=13, p=0.27)$, or breeding period core area $(\mathrm{W}=$ $13, p=0.27)$. Total length was not correlated with home range size $(\mathrm{P}=0.08, S=264, p$ $=0.82$ ) or core use area (Figure $3 ; \mathrm{P}=-0.10, S=314, p=0.77$ ). Total length was also not correlated with breeding period home range size $(\mathrm{P}=0.16, S=138, p=0.66)$, breeding period core use area $(\mathrm{P}=0.12, S=146, p=0.76)$, wet season home range size $(\mathrm{P}=0.08$, $S=152, p=0.84)$, wet season core use area $(\mathrm{P}=0.07, S=154, p=0.86)$, dry season home range size $(\mathrm{P}=0.11, S=254, p=0.73)$, or dry season core use area $(\mathrm{P}=-0.27, S=$ $364, p=0.39$ ). Body condition was not correlated with home range size (Figure 3; $\mathrm{P}=$ $0.20, S=228, p=0.53)$ or core use area $(\mathrm{P}=0.08, S=262, p=0.80)$. Body condition was also not correlated with breeding period home range size $(\mathrm{P}=0.25, S=124, p=$ $0.49)$, breeding period core use area $(\mathrm{P}=0.30, S=116, p=0.41)$, dry season home range size $(\mathrm{P}=0.50, S=144, p=0.10)$, dry season core use area $(\mathrm{P}=0.30, S=200, p=0.34)$, 
wet season home range $(\mathrm{P}=0.03, S=160, p=0.95)$, or wet season core use area $(\mathrm{P}=$ $0.36, S=224, p=0.31)$.

Individual animals did not differ in seasonal space use for 95\% UD areas (V $=23$, $p=0.70)$ or $50 \% \mathrm{UD}$ areas $(\mathrm{V}=40, p=0.23)$ across the wet and dry seasons. Also, individual animals did not have different 95\% UD areas $(\mathrm{V}=38, p=0.32)$ and $50 \% \mathrm{UD}$ areas $(\mathrm{V}=45, p=0.08)$ during the breeding period compared to outside this time.

\section{Movement and activity}

Activity was higher for males compared to females (Figure 4; $\mathrm{W}=687737, p<$ 0.001 ), which averaged $1,565 \pm 2,951$ compared to $236 \pm 509$, respectively. At the population-level, mean movement activity was greater during the breeding period (mean $=1,710 \pm 3,229)$ than it was during the non-breeding period $($ mean $=1,279 \pm 2,629)$ (Figure $4 ; \mathrm{W}=927374, p<0.001$ ). Mean movement activity was three times greater in the wet season compared to the dry season (Figure 4; $\mathrm{W}=1305346, p<0.001$ ). Even with breeding period locations removed, wet season activity was significantly higher than in the dry season $(\mathrm{W}=786426, p<0.001)$. Animals tagged in the freshwater marsh exhibited almost a fourth of the movement activity (mean $=555 \pm 948)$ of those captured in the river $($ mean $=2,096 \pm 3,551)($ Figure $4 ; \mathrm{W}=670109, p<0.001)$. However, the relationship was driven by higher wet season movement activity by riverine animals $($ mean $=2,815 \pm 3,515)$ compared to marsh animals $($ mean $=585 \pm 916)$. In the river, movement activity was not correlated with the fraction of the moon illuminated $(\mathrm{P}=$ $0.05, S=558707901, p=0.05)$. Movement activity for riverine animals was positively correlated to daily rainfall $(\mathrm{P}=0.08, S=489816755, p<0.01)$ and average daily 
temperature $(\mathrm{P}=0.32, S=360502079, p<0.001)$. For the animals in the river, salinity was negatively correlated with movement activity $(\mathrm{P}=-0.14, S=600871493, p<0.001)$. In the river, there was no relationship between movement and water level $(\mathrm{P}=0.04, S=$ $510779531, p=0.13)$. In the marsh, movement activity was not correlated with daily rainfall $(\mathrm{P}=-0.05, S=381927162, p=0.06)$. Movement activity for marsh animals was positively correlated with the fraction of the moon illuminated $(\mathrm{P}=0.11, S=321954250$, $p<0.001)$ and average daily temperature $(\mathrm{P}=0.06, S=342664901, p<0.05)$. In the marsh there was a negative relationship between water level and movement $(\mathrm{P}=-0.49, S$ $=538902460, p<0.001)$. Body condition and movement activity were negatively correlated though the correlation coefficient was low (Figure 3; $\mathrm{P}=-0.14, S=$ 4039717174, $p<0.001)$. This relationship was stronger in the wet season $(\mathrm{P}=-0.42)$ compared to the dry $(\mathrm{P}=0.10)$. Body size was not correlated with movement activity (Figure 3; $\mathrm{P}=0.01, S=3491790461, p=0.52$ ).

\section{Discussion}

Alligators are physiologically limited in their distribution within coastal estuaries and require regular access to low salinity water because they lack functioning salt glands (Dunson and Mazzotti 1989; Lauren 1985). Short-term excursion from freshwater to high salinity waters, however, allow individuals to access marine resources (Rosenblatt and Heithaus 2011). Estuarine alligators do not uniformly move to access the diversity of habitats and exhibit considerable individual variation in movement behavior and habitat use. Movement tactics of estuarine alligators can range from being residential in a particular habitat or commuting from the mid-estuary to freshwater areas or taking brief 
long-distance travels downstream to exploit prey-rich marine food webs (Rosenblatt and Heithaus 2011; Fujisaki et al. 2014; Nifong and Silliman 2017). Consistent with previous work in estuaries, some of our tracked animals were residents of a habitat and others showed commuting behavior. However, we also observed differences in the degrees and directions of commuting between major habitats, which are less documented in other studies. Half of our animals moved between two or more general habitats in the estuary. We observed a range of general movement tactics with movements between the midestuary and upstream network, long-distance movements across the estuary, and movement from the marsh into the stream network.

We found diversity in the movement tactics between animals spending most of their time in the riverine compared to individuals in the marsh areas of the estuary. Our data indicate that marsh alligators have generally small and stable home ranges and are largely sedentary compared to animals in the estuarine river environment. Riverine crocodilians appear to move more than those residing in marsh habitats (Kay 2004;

Rosenblatt et al. 2013; Chapter 3). One explanation is that the two general habitats have a different energetic cost of movement. For instance, riverine animals may be aided or take advantage of water flow (Kay 2004), but marsh animals may be more restricted because of dense stands of macrophytes in wet prairies (Morea 1999; McNease and Joanen 1974; Saalfeld 2010). However, other explanations for differences in movements between general habitat types such as variation in distribution of prey, effects on physiological performance, and differences in facilitation of social structures have not been explored. In the river, we documented high variation among individuals in movement tactics. Some individuals occupied small and stable ranges like those in the marsh while others 
exhibited considerably greater range sizes and more directional movements across the estuary to downstream habitats.

Shifts in movement behaviors as a result of changing and interacting environmental conditions are likely complicated patterns for most animals especially in dynamic ecosystems like estuaries. In the marsh, movement increased with decreasing water levels associated with the dry season, but movement had no relationship to rainfall. Marsh drydown concentrates fish and invertebrate prey into deep-water refuges (Rehage and Loftus 2007). The concentration of resources may increase foraging efficiency, but it may also encourage increased movement to account for depleting food patches as water dries out. The dry season also corresponds to cooler temperatures which are thought to limit alligator activity (Chabreck 1965; Goodwin and Marion 1979; Lang 1987). We observed decreased movement activity with lower daily temperatures for alligators in the marsh and the river. Alligators are generally least active in colder months, and at both high and low temperatures alligators will need to use sedentary thermoregulatory behaviors (e.g., basking, denning, aquatic buffering) (Chabreck 1965; Goodwin and Marion 1979; Lang 1987). We also found that movement activity was positively correlated with moon illumination for marsh animals, but not with riverine animals. Increased prey activity with increased moon illumination is thought to increase alligator foraging efficiency (Eversole et al. 2015).

Overall, riverine animals had larger ranges in the wet season compared to animals in the marsh, but similar range sizes in the dry season. Riverine animals also had four times higher movement activity estimates driven primarily by increased wet season activity than marsh animals. In fact, movement activity for the riverine animals increased 
with decreasing salinity typically experienced throughout the estuary in the wet season. We also observed higher movement activity with increased daily rainfall for riverine animals. Animals in the riverine environment compared to the marsh are able to access more habitats and roam a larger area during the wet season from increased precipitation and higher freshwater inflow decreasing salinities throughout the estuary. These changing conditions shift the balance of higher physiological costs of saltwater stress and better foraging returns downstream. Interestingly, in our entire sample and for the group of riverine alligators, we did not see a pattern of individuals changing their space use across the wet and dry seasons. However, some riverine animals did have larger wet season ranges than in the dry season including one of the downstream commuters (i.e., six times larger wet season range than dry season range). The riverine animals also had larger ranges during the breeding period than outside the breeding period. Courtship displays and mating occurs primarily in open freshwater (Lang 1987), which is more abundant in the upper riverine system compared to the marsh. The river may encourage alligators to move upstream more often and greater distances to mate than marsh habitats. Animals in the marsh may already incorporate desirable open water areas in their annual home ranges and stay put for mating encounters.

Many animals exhibit strong seasonal changes in movements and habitat use. Though our tagged individuals did not change the amount of space use across seasons, movement activity was greater in the wet season compared to the dry season. Our results are contrary to an acoustic telemetry study in Shark River; Rosenblatt et al. (2013) found that alligator dry season ranges were twice the size and were farther upstream than the wet season ranges, but movement rates were not different across seasons. The larger 
ranges in the dry season were thought to be caused by the incorporation of the shift in habitat use from the downstream to the upstream accounting for a large portion of dry season activity (Rosenblatt et al. 2013). As a result of habitat complexity, the acoustic array of Shark River Estuary is confined to the river channel and is not able to discern movement in the marsh and mangrove forest. We hypothesize that the differences observed between our study and Rosenblatt et al. (2013) is related to our ability to detect wet season movements into these flooded complex habitats as a result of the difference in telemetry technologies.

Commuting behavior between freshwater and marine areas appears to be a common tactic of several estuarine species even in the Shark River Estuary including common snook (Centropomus undecimalis; Boucek and Rehage 2013) and juvenile bull sharks (Carcharhinus leucas; Matich and Heithaus 2015). The commuting tactic allows for estuarine animals to gain access to foraging prey-rich marine foraging patches and upstream refuges relatively safe from the large predators that are abundant at the river mouth (Matich and Heithaus 2015). Crocodilians have also demonstrated commuting behaviors in estuaries. For example, some tracked estuarine crocodiles, Crocodylus porosus, traveled more than $50 \mathrm{~km}$ between freshwater rivers and marine coastlines (Campbell et al. 2010). In another study of alligators, one individual made 43 trips in 483 tracking days across a more than $13 \mathrm{~km}$ area (Rosenblatt and Heithaus 2011). We observed a variety of commuting behaviors in our tagged population. Foraging is the most likely explanation for commuting behavior because moving downstream would serve no reproductive or thermoregulatory purpose (Mazzotti and Brandt 1994;

Rosenblatt and Heithaus 2011; Fujisaki et al. 2014). The SRE is phosphorus-limited with 
productivity decreasing as distance from the river mouth and Gulf of Mexico increases moving upstream (Childers et al. 2006). Because of the high productivity, coastal areas of the SRE have greater prey resources available to large-bodied predators in the wet season than mid-estuary and upstream areas. Prey availability in the dry season across the estuary is more complicated. In the dry season, many freshwater marsh fishes move into the mangrove channels upstream and mid-estuary to avoid marsh dry down (Rehage and Loftus 2007). The additional prey subsidy and the higher salinities downstream may limit downstream commutes in the dry season (Rosenblatt and Heithaus 2011). Commuting obviously confers some advantage likely to exploit the prey-rich marine habitats downstream even with the added physiological stress caused from higher salinity. Our tagged commuters generally made trips in both seasons supporting the findings of Rosenblatt and Heithaus (2011) who observed that most downstream commuters made trips in both seasons but several animals made more downstream trips and spent longer in marine habitats during the wet season when salinity was lower and temperature is higher. Not observed in other estuarine alligator studies, we detected relatively long-term stays between movements across habitats. For instance, two animals stayed months in high salinity downstream lower river habitats. We are unsure exactly how these animals were mitigating salt stress but perhaps more accurate movement technologies such as GPS tags or salinity biologging devices could be useful in future studies. Interestingly, the timings of zone changes varied even for the animals commuting in the upstream habitats. For instance, in the late dry season, one animal made several trips to upriver from the midestuary and another moved several times to the marsh from the upper river. The 
movements upstream in the dry season may be a response to changing prey distributions and hydrology.

There is considerable consistency in alligator movement behaviors across years with animals not switching general movement tactics in long-term tracking studies (Rosenblatt and Heithaus 2011; Rosenblatt et al. 2013; Strickland et al. 2020). With no detectable body size or body condition differences in downstream commuters compared to other animals with different movement tactics, Rosenblatt and Heithaus (2011) suggested the tactic was driven largely by innate differences between individuals. In our study, there were no differences in body sizes or conditions between the two broad habitats and generally body size and condition were not associated with space use or movements. We suggest as well that individual variation accounts for the major differences in broad movement tactics; however, we did observe major differences by sex.

Male alligators had home ranges more than five times the size (still almost twice the size with commuters removed), and had over six times higher movement activity, than females. Even though alligator studies often report that male alligators move more often and across greater distances than females, the reasons are uncertain (Joanen and McNease 1970, 1972; Goodwin and Marion 1979). Given that breeding season range sizes were not different by sex, we do not think that reproduction was the driver for increased space use in my study. Male and female alligators also did not show differences in the core use area size or across seasons indicating that the differences observed are probably not determined by physiological requirements. The most likely driver for differences in space use by sex is the distribution of sexes by general habitat. Indeed, 
males in the marsh did not have different range sizes from females. There were only two female alligators for which there were enough locations to analyze space use and movements and compare to the males. Both females were caught in the marsh and not the riverine habitats. The SRE is a highly male-biased population (Rosenblatt and Heithaus 2011; Frank Mazzotti, unpublished data). It is suspected that the lack of nesting substrate and potentially stressful salinities relegate females to the peripheral marsh habitats of the estuary (Rosenblatt et al. 2013).

Many studies of crocodilians demonstrate that movement and space use increase around spring courtship and mating (Joanen and McNease 1970; McNease and Joanen 1974, Goodwin and Marion 1979; Kay 2004). Movements of male crocodilians before breeding are spent displaying social dominance and establishing territories whereas during breeding these sites are patrolled (Lang 1987; Mazzotti and Brandt 1994). Mating generally happens in open freshwater to make dominance displays and courtship rituals conspicuous (Lang 1987; Joanen and McNease 1972). Generally, breeding females move to these habitats (e.g., canals, ponds, river channels) to mate with males (Mazzotti and Brandt 1994). Movement activity peaked for both sexes in the breeding period. Though the population as a whole did not change the amount of space used over the breeding period, six of ten animals for which we were able to estimate breeding period space use had ranges more than twice as large compared to ranges outside of the breeding period; two animals had the opposite pattern and another two had similar range sizes across the two periods. Increasing movement during the breeding period and moving from area to area increases mate encounter rates and potentially mating chances. Four of our tagged males showed orders of magnitude higher activity during the breeding period compared 
to the non-breeding period. Habitat use shifts occurred for two males corresponding to the breeding period. One animal moved from the upper river network to the marsh and another moved from the upper river to the mid-estuary; both of these broad habitat shifts began at the onset of the breeding period in April and lasted until the end in June. Moving from the upper river to the mid-estuary is surprising given the lack of freshwater for mating. We speculate that the animal was driven from preferable habitat by another male.

It is unknown if either of the two tagged females were nesting. One female (x133378) had a 19-fold peak of mean activity in the breeding period of April and May 2014 (mean motion variance $=825 \pm 911$ ) but was relatively sedentary outside of the spring of 2014 from its tagging in November 2013 and its last transmission in September 2014 (mean motion variance $=43 \pm 87$ ). It is generally thought that female alligators are sedentary outside of the breeding period and remain near their nesting and denning locations (Joanen and McNease 1970; Goodwin and Marion 1979; Rootes and Chabreck 1993). Also, tagged female alligators were smaller on average than males. Male crocodilians grow to larger sizes than females presumably associated with advantages in resources defense and mating compared to the shift towards internal reproductive investment by females at sexual maturity (McIlhenny 1935; Platt et al. 2011; Woodward et al 1995).

Body size is an important determinant for movements and habitat use for crocodilians given that their social dominance hierarchies are largely determined by displays of body size (Kay 2004; Lang 1987). Total length was not correlated with range size across season or the breeding period nor did we see a relationship between movement activity and body size. Captive crocodilians are thought to exhibit size-based 
dominance hierarchies with large males generally controlling access to both food and mates (Lang 1987; Johnson 1973). However, field studies of animal movement, resource use, and range size rarely depend on direct observations and do not account for the potential interaction of hierarchies with population density and habitat structure (Jetz et al. 2004; Strickland et al. 2016). We suspect our limited body size range and small sample size limited the detectability of a potential relationship.

Animal health is often linked to fitness and proxied by well-established measures of body condition (Baines et al. 2015; Jakob et al. 1996). The link of body condition to dispersal and movement is complicated, but is important for understanding behavioral drivers and their contexts (Baines et al. 2015). Our animals were distributed relatively evenly across the four classes of body condition ranging from poor to excellent (Brandt et al. 2016). In our study, body condition was not correlated with range size, and we saw no differences in body conditions of riverine or marsh alligators or between males and females. However, animals with high body condition moved less than animals in poor condition. Animals with high body conditions may have access to higher quality and/or more resources and may not be forced to search across large distances. The relationship of movement and condition was especially pronounced in the wet season when prey distributions are less concentrated and poor condition animals may have spent more time and energy searching to meet energetic demands. Importantly, our measure of body condition was calculated using data at capture. Alligator body condition can change quite rapidly through the year and over an animal's lifetime (Brandt et al. 2016). Thus, condition at capture may or may not be related to when movements were recorded so a 
weak relationship is not surprising. Future studies may be able to take advantage of biologging technologies and robust recapture-resample frameworks.

In conclusion, we found that differences in movement behavior of alligators can be explained by both abiotic (e.g., temperature and water level) and internal state factors (e.g., sex and body condition). We detected multiple behavioral types including relatively sedentary residential behavior and several directions and durations of commuting behavior. Individual variation in movement tactics may facilitate dissimilarity in ecological roles. For instance, commuters moving between oligotrophic upstream habitats and productive marine habitats have the potential to transport nutrients across these disparate habitats. Also, sedentary residents of one habitat are likely to concentrate and recycle nutrients at high rates locally that might be particularly important in nutrient-poor systems. Future work identifying the major movement behaviors, their drivers, and their frequency in a particular population may allow for predictive models and a better understanding of the community- and ecosystem-level impact of ecologically important consumers.

\section{Acknowledgements}

This work was supported by the National Science Foundation through the Florida Coastal Everglades Long-Term Ecological Research program under Grant \#DEB1237517 and DEB-1832229. We are grateful to many field and lab volunteers that assisted with capture and sample processing. Frank Mazzotti, Jeff Beauchamp, Kirk Gastrich, and Mike Heithaus were critical to the project and chapter. Adam Rosenblatt's pioneering work directed the line of investigation for this project. Joel Trexler's 
enthusiasm and input into the work was tremendously valuable. Mo van Zinnicq Bergmann provided draft $\mathrm{R}$ code that was helpful for the analysis. Katherine Strickland provided graphic design assistance. This is a contribution from the Center for Coastal Oceans Research in the Institute for Water and Environment at Florida International University. BAS was supported by the University Graduate School and Department of Biological Sciences assistantships at Florida International University as well as an Everglades Foundation fellowship. Research and animal procedures were conducted under the auspices of protocol \#IACUC-15-044-CR01 from the Institutional Animal Care and Use Committee of the University of Florida and in accordance with sampling permits \#EVER-2013-SCI-0020 and \#EVER-2015-SCI-0036 granted by Everglades National

Park.

Literature Cited

Araujo, MS, DI Bolnick, and CA Layman. 2011. The ecological causes of individual specialization. Ecology Letters 14:948-958.

Baines CB, McCauley SJ, Rowe L. 2015. Dispersal depends on body condition and predation risk in the semi-aquatic insect, Notonecta undulata. Ecology and Evolution 5(12): 2307-2316.

Bivand, R. and N. Lewin-Koh. 2019. Maptools: tools for handling spatial objects. R package version 0.9-5. https://CRAN.R-project.org/package=maptools.

Bolnick, D.I., Svanback, R., Fordyce, J.A., Yang, L.H., Davis, J.M., Hulsey, C.D. et al. (2003). The ecology of individuals: incidence and implications of individual specialization. Am. Nat., 161, 1-28.

Bolnick, DI, P Amarasekare, MS Araujo, R Burger, JM Levine, M Novak, VHW Rudolf, SJ Schreiber, MC Urban, and D Vasseur. 2011. Why intraspecific trait variation matters in community ecology. Trends in Ecology and Evolution 26(4):183-192. 
Boucek, RE and JS Rehage. 2013. No free lunch: displaced marsh consumers regulate a prey subsidy to an estuarine consumer. Oikos 000:1-12.

Brandt, L.A., J.S. Beauchamp, B.M. Jeffery, M.S. Cherkiss, and F.J. Mazzotti. 2016. Fluctuating water depths affect American alligator (Alligator mississippiensis) body condition in the Everglades, Florida, USA. Ecological Indicators 67:441450.

Brien, M., G. Webb, C. Manolis, G. Lindner, and D. Ottoway. 2010. A method for attaching tracking devices to crocodilians. Herpetological Review 41:305-308.

Byrne, M.E., J.C. McCoy, J.W. Hinton, M.J. Chamberlain, and B.A. Collier. 2014. Using dynamic Brownian brige movement modelling to measure temporal patterns of habitat selection. Journal of Animal Ecology 83:1234-1243.

Campbell, H. A., M. E. Watts, S. Sullivan, M. A. Read, S. Choukroun, S. R. Irwin, and C. E. Franklin. 2010. Estuarine crocodiles ride surface currents to facilitate longdistance travel. Journal of Animal Ecology 79:955-964.

Chabreck, R. H. 1963. Methods of capturing, marking, and sexing alligators. Proceedings of the Southeastern Association of Game and Fish Commissioners 17:47-50.

Chabreck, R. H. 1965. The movement of alligators in Louisiana. Proceedings of the Southeastern Association of Game and Fish Commissioners 19:102-110.

Childers, D. L. 2006. A synthesis of long-term research by the Florida Coastal Everglades LTER Program. Hydrobiologia 569:531-544.

Daoust, R. J., and D. L. Childers. 1999. Controls on emergent macrophyte composition, abundance, and productivity in freshwater everglades wetland communities. Wetlands 19:262-275.

Duffy, M.A. (2010). Ecological consequences of intraspecific variation in lake Daphnia. Freshwat. Biol., 55, 995-1004.

Dunson W, Mazzotti FJ. 1989. Salinity as a limiting factor in the distribution of reptiles in Florida Bay: a theory for the estuarine origin of marine snakes and turtles. Bulletin of Marine Science 44;229-244.

Estes, J. A., J. Terborgh, J. S. Brashares, M. E. Power, J. Berger, W. J. Bond, S. R. Carpenter, T. E. Essington, R. D. Holt, J. B. C. Jackson, R. J. Marquis, L. Oksanen, T. Oksanen, R. T. Paine, E. K. Pikitch, W. J. Ripple, S. A. Sandin, M. Scheffer, T. W. Schoener, J. B. Shurin, A. R. E. Sinclair, M. E. Soulé, R. Virtanen, and D. A. Wardle. 2011. Trophic downgrading of planet Earth. Science 333:301-306. 
Eversole, C.B., S.E. Henke, D.B. Wester, B.M. Ballard, and R.L. Powell. 2015. Responses of American Alligators to environmental conditions: implications for population and ecosystem monitoring. Herpetologica 71:37-45.

Fieberg, J. and C.O. Kochanny. 2005. Quantifying home-range overlap: the importance of the utilization distribution. Journal of Wildlife Management 69(4):1346-1359.

Fretwell SD. 1972. Populations in a seasonal environment. Monographs in population biology. Princeton, New Jersey: Princeton University Press, PMID: 4680650.

Fretwell, S.D. and Lucas, H.L. (1970) On territorial behavior and other factors influencing habitat distribution in birds. I. Theoretical development. Acta Biotheoretica, 19, 16-36. doi:10.1007/BF01601953

Fujisaki, I., K. M. Hart, F. J. Mazzotti, M. S. Cherkiss, A. R. Sartain, B. M. Jeffery, J. S. Beauchamp, and M. Denton. 2014. Home range and movements of American alligators (Alligator mississippiensis) in an estuary habitat. Animal Biotelemetry $2: 1-10$.

Goodwin, T. M., and W. R. Marion. 1979. Seasonal activity ranges and habitat preferences of adult alligators in a north-central Florida lake. Journal of Herpetology 13:157-164.

Jakob, E.M., S.D. Marshall and G.W. Uetz. 1996. Estimating fitness: a comparison of body condition indices. Oikos 77: 61-67.

Jetz W, Carbone C, Fulford J, Brown JH. 2004 The scaling of animal space use. Science 306, 266 - 268. (doi:10.1126/science.1102138).

Joanen, T., and L. McNease. 1970. A telemetric study of nesting female alligators on Rockefeller Refuge, Louisiana. Proceedings of the Southeastern Association of Game and Fish Commissioners 20:175-193.

Joanen, T., and L. McNease. 1972. A telemetric study of adult male alligators on Rockefeller Refuge, Louisiana. Proceedings of the Southeastern Association of Game and Fish Commissioners 26:252-275.

Johnson, CR. 1973. Behaviour of the Australian crocodiles, Crocodylus johnstoni and $C$. porosus. Zool. J. Linn. Soc. 52:315-336.

Kay, W. R. 2004. Movements and home ranges of radio-tracked Crocodylus porosus in the Cambridge Gulf region of Western Australia. Wildlife Research 31:495-508. 
Kie, J.G., J. Matthiopoulos, J. Fieberg, R.A. Powell, F. Cagnacci, M.S. Mitchell, J. Gaillard, and P.R. Moorcroft. 2010. The home range concept: are traditional estimators still relevant with modern telemetry technology? Phil. Trans. R. Soc. B. 365: 2221-2231.

Komers, P. E. 1997. Behavioural plasticity in variable environments. - Can. J. Zool. 75: 161-169.

Kranstauber, B., R. Kays, S. D. Lapoint, M. Wikelski, and K. Safi. 2012. A dynamic Brownian bridge movement model to estimate utilization distributions for heterogeneous animal movement. Journal of Animal Ecology 81:738-746.

Kranstauber, B., M. Smolla, and A.K. Scharf. 2019. Move: visualizing and analyzing animal track data. R package version 3.2.2. https://CRAN.Rproject.org/package $=$ move.

Kushlan, J. A. 1974. Observations on the role of the American alligator in the Southern Flordia wetlands. Copeia 4:993-996.

Lang, J. W. 1987. Crocodilian behaviour: implications for management. Pages 273-293 in G. Webb, S. C. Manolis, and P. J. Whitehead, editors. Wildlife management: crocodiles and alligators. Surrey Beatty \& Sons, Sydney, Australia.

Lauren D. 1985. The effect of chronic saline exposure on the electrolyte balance, nitrogen metabolism, and corticosterone titer in the American alligator, Alligator mississippiensis. Comparative Biochemistry and Physiology 81A;217-223.

Massie JA, Strickland BA, Santos R, Hernandez J, Viadero N, Boucek RE, Willoughby H, Heithaus MR, Rehage JS. 2019. Going downriver: patterns and cues in hurricane-driven movements of common snook in a coastal river. Estuaries and Coasts. doi: 10.1007/s12237-019-00617-y.

Matich, P., and M.R. Heithaus. 2012. Effects of an extreme temperature event on the behavior and age structure of an estuarine top predator (Carcharhinus leucas). Marine Ecology Progress Series 447: 165- 178. https://doi.org/10.3354/meps09497.

Matich, P., and M.R. Heithaus. 2015. Individual variation in ontogenetic niche shifts in habitat use and movement patterns of a large estuarine predator (Carcharhinus leucas). Oecologia 178 (2): 347-359. https://doi.org/10.1007/s00442-015-3253-2.

Mazzotti, F. J., and L. A. Brandt. 1994. Ecology of the American alligator in a seasonally flucutating environment. S. M. Davis and W. A. Park, editors. Everglades: The Ecosystem and Its Restoration. St. Lucie Press. 
Mazzotti, F.J., F.R. Best, L.A. Brandt, M.S. Cherkiss, B.M. Jeffery, and K.G. Rice. 2009. Alligators and crocodiles as indicators for restoration of Everglades ecosystems. Ecological Indicators 9(6):S137-S149.

McIlhenny, E.A. 1935. The alligator's life history. Boston, Massachusetts: Christopher Publishing House.

McNease, L., and T. Joanen. 1974. A study of immature alligators on Rockefeller Refuge, Louisiana. Proceedings of the Southeastern Association of Game and Fish Commissioners 28:482-500.

Morea, C. R. 1999. Home range, movement, and habitat use of the American alligator in the Everglades. M.S. Thesis, University of Florida, Gainesville, Florida. 88 pp.

Nathan, R., WM Getz, E Revilla, M Holyoak, R Kadmon, D Saltz, and PE Smouse. 2008. A movement ecology paradigm for unifying organismal movement research. PNAS 105(49):19052-19059.

National Oceanic and Atmospheric Administration (NOAA). 2019. National Centers for Environmental Information. https://www.ncei.noaa.gov/. Accessed 20 July 2019.

Nifong, J. C., and B. R. Silliman. 2013. Impacts of a large-bodied, apex predator (Alligator mississippiensis Daudin 1801) on salt marsh food webs. Journal of Experimental Marine Biology and Ecology 440:185-191.

Nifong, JC, and BR Silliman. 2017. Abiotic factors influence the dynamics of marine habitat use by a highly mobile "freshwater" top predator. Hydrobiologia DOI 10.1007/s10750-017-3255-7.

Platt SG, Rainwater TR, Thorbjanarson JB, Finger AG, Anderson TA, and McMurry ST. 2011. Size estimation, morphometrics, sex ratio, sexual size dimorphism, and biomass of Crocodylus acutus in the coastal zone of Belize. Salamandra 47:179192.

Reale, D. et al. 2007. Integrating animal temperament within ecology and evolution. Biological Reviews 82:291-318.

Rehage, J.S., and W.F. Loftus. 2007. Seasonal fish community variation in headwater mangrove creeks in the southwestern Everglades: an examination of their role as dry-down refuges. Bulletin of Marine Science 80:625-645.

Romigh, M. M., S. E. Davis, V. H. Rivera-Monroy, and R. R. Twilley. 2006. Flux of organic carbon in a riverine mangrove wetland in the Florida Coastal Everglades. Hydrobiologia 569:505-516. 
Rootes, W.L. and R.H. Chabreck. 1993. Reproductive status and movement of adult female alligators. Journal of Herpetology 27: 121-126.

Rosenblatt, A. E., and M. R. Heithaus. 2011. Does variation in movement tactics and trophic interactions among American alligators create habitat linkages? The Journal of Animal Ecology 80:786-798.

Rosenblatt, A. E., M. R. Heithaus, F. J. Mazzotti, M. Cherkiss, and B. M. Jeffery. 2013. Intra-population variation in activity ranges, diel patterns, movement rates, and habitat use of American alligators in a subtropical estuary. Estuarine, Coastal and Shelf Science 135:182-190.

Rosenblatt, A.E., J.C. Nifong, M.R. Heithaus, F.J. Mazzotti, M.S. Cherkiss, B.M. Jeffery, R.M. Elsey, R.A. Decker, B.R. Silliman, L.J. Guillette, R.H. Lowers, J.C. Larson. 2015. Factors affecting individual foraging specialization and diet stability across the range of a large "generalist" apex predator. Oecologia 178:5-16.

Rudnick, D. T., Z. Chen, D. L. Childers, and T. D. Fontaine. 1999. Phosphorus and nitrogen inputs to Florida Bay: The importance of the everglades watershed. Estuaries 22:398-416.

Saaleld, DT. 2010. American alligator ecology in inland wetlands of east Texas. Stephen F. Austin State University. PhD dissertation, 297 pp.

Said, S. and S. Servanty. 2005. The influence of landscape structure on female roe deer home-range size. Landscape Ecology 20: 1003-1012.

Schmitz, O. J., D. Hawlena, and G. C. Trussell. 2010. Predator control of ecosystem nutrient dynamics. Ecology Letters 13:1199-1209.

Schreiber, S.J., Burger, R. \& Bolnick, D.I. (2011). The community effects of phenotypic and genetic variation within a predator population. Ecology, DOI: 10.1890/102071.1.

Sklar, F.H., Chimney, M.J., Newman, S., McCormick, P., Gaw- lik, D., Miao, S., McVoy, C., Said, W., Newman, J., Coro- nado, C., Crozier, G., Korvela, M., Rutchey, K., 2005. The ecological-societal underpinnings of Everglades restoration. Front. Ecol. Environ. 3, 161-169.

Strickland, BA, K Gastrich, FJ Mazzotti, JA Massie, V Paz, N Viadero, JS Rehage, and MR Heithaus. 2020. Variation in movement behaviors of alligators after a major hurricane. Animal Biotelemetry 8(7):1-10.

Strickland, B. A., F. J. Vilella, and J. L. Belant. 2016. Scale-dependent habitat selection and size-based dominance in adult male American alligators. PLoS ONE 11:1-16. 
Subalusky, A. L., L. A. Fitzgerald, and L. L. Smith. 2009. Ontogenetic niche shifts in the American alligator establish functional connectivity between aquatic systems. Biological Conservation 142:1507-1514.

Svanbäck, R., and D. I. Bolnick. 2007. Intraspecific competition drives increased resource use diversity within a natural population. Proceedings of the Royal Society B 274:839-844.

Thieurnmel, B. and A. Elmarchraoui. 2019. suncalc: compute sun position, sunlight phases, moon position, and lunar phase. $\mathrm{R}$ package version 0.5.0. https://CRAN.R-project.org/package=suncalc.

Woodward, A.R., J.H. White, and S.B. Linda. 1995. Maximum size of the alligator (Alligator mississippiensis). Journal of Herpetology 29(4): 507-513.

United States Geological Survey (USGS). 2019. Everglades Depth Estimation Network database. https://sofia.usgs.gov/eden/. Accessed 26 September 2019. 
Table 1. Percent of time spent in each habitat "zone" and number and mean duration of each zone change for American alligators (Alligator mississippiensis) in Shark River Estuary, Florida, USA tracked using satellite telemetry (2013-2016) for which there were sufficient relocations.

\begin{tabular}{|c|c|c|c|c|c|c|c|}
\hline \multirow{2}{*}{ Individual } & \multirow{2}{*}{$\begin{array}{c}\text { Capture } \\
\text { Area }\end{array}$} & \multirow{2}{*}{$\begin{array}{c}\text { Coastal } \\
\text { Rivers } \\
\% \text { time }\end{array}$} & \multirow{2}{*}{$\begin{array}{c}\text { Mid-estuary } \\
\text { o time }\end{array}$} & \multirow{2}{*}{$\begin{array}{c}\text { Upper River } \\
\text { \% time }\end{array}$} & \multirow{2}{*}{$\begin{array}{c}\text { Marsh } \\
\text { Transition } \\
\text { \% time }\end{array}$} & \multicolumn{2}{|c|}{ Zone changes } \\
\hline & & & & & & $n$ & $\begin{array}{l}\text { Mean duration } \\
\pm S D \text { (days) }\end{array}$ \\
\hline 123531 & EST & 57 & 2 & 0 & 41 & 8 & $34.7 \pm 47.6$ \\
\hline 123532 & EST & 84 & 16 & 0 & 0 & 2 & $67.0 *$ \\
\hline 129516 & EST & 0 & 46 & 54 & 0 & 20 & $5.1 \pm 8.1$ \\
\hline 129517 & EST & 0 & 100 & 0 & 0 & 0 & -- \\
\hline 129519 & EST & 0 & 1 & 99 & 0 & 4 & $17.3 \pm 29.1$ \\
\hline 133375 & EST & 0 & 80 & 1 & 19 & 11 & $12.8 \pm 14.0$ \\
\hline 133376 & TRS & 0 & 0 & 0 & 100 & 0 & -- \\
\hline 133377 & TRS & 0 & 0 & 0 & 100 & 0 & -- \\
\hline 133378 & TRS & 0 & 0 & 0 & 100 & 0 & -- \\
\hline 133379 & TRS & 0 & 0 & 0 & 100 & 0 & -- \\
\hline 133380 & TRS & 0 & 0 & 0 & 100 & 0 & -- \\
\hline 146674 & TRS & 0 & 0 & 83 & 17 & 8 & $10.0 \pm 16.0$ \\
\hline
\end{tabular}

*Animal 123532 only took one trip. 
Table 2. Median and range of home range and core use area size, defined by the area in $\mathrm{km}^{2}$ of the $95 \%$ and $50 \%$ utilization distributions, respectively, and mean and standard deviation (SD) of Brownian motion variance, an indicator of movement activity, across seasons and breeding period for American alligators (Alligator mississippiensis) in Shark River Estuary, Florida, USA tracked using satellite telemetry (2013-2016) for which there were sufficient relocations.

\begin{tabular}{c|c|c|c|c|c}
\multirow{2}{*}{ Timeframe } & & Home Range & Core Use Area & \multicolumn{2}{|c}{ Motion variance } \\
\cline { 2 - 6 } & $n$ (animals) & $\begin{array}{c}\text { Median (range) } \\
\left(\mathrm{km}^{2}\right)\end{array}$ & $\begin{array}{c}\text { Median (range) } \\
\left(\mathrm{km}^{2}\right)\end{array}$ & $n$ (relocations) & Mean $\pm S D$ \\
\hline Study period & 12 & $14.0(4.6-190.5)$ & $1.4(0.5-14.0)$ & 3,068 & $1,374 \pm 2,778$ \\
\hline Wet season & 10 & $13.7(5.2-219.6)$ & $1.2(0.5-20.7)$ & 1,559 & $2,009 \pm 3,056$ \\
\hline Dry season & 12 & $14.3(4.0-69.8)$ & $1.4(0.5-3.3)$ & 1,509 & $667 \pm 2,228$ \\
\hline Breeding period & 10 & $19.4(8.9-84.9)$ & $2.4(1.4-6.4)$ & 611 & $1,710 \pm 3,229$ \\
\hline Non-breeding period & 10 & $14.0(2.7-207.7)$ & $1.2(0.4-17.6)$ & 2,457 & $1,279 \pm 2,629$
\end{tabular}


Figure 1: Map of Shark River Estuary, Florida, USA.

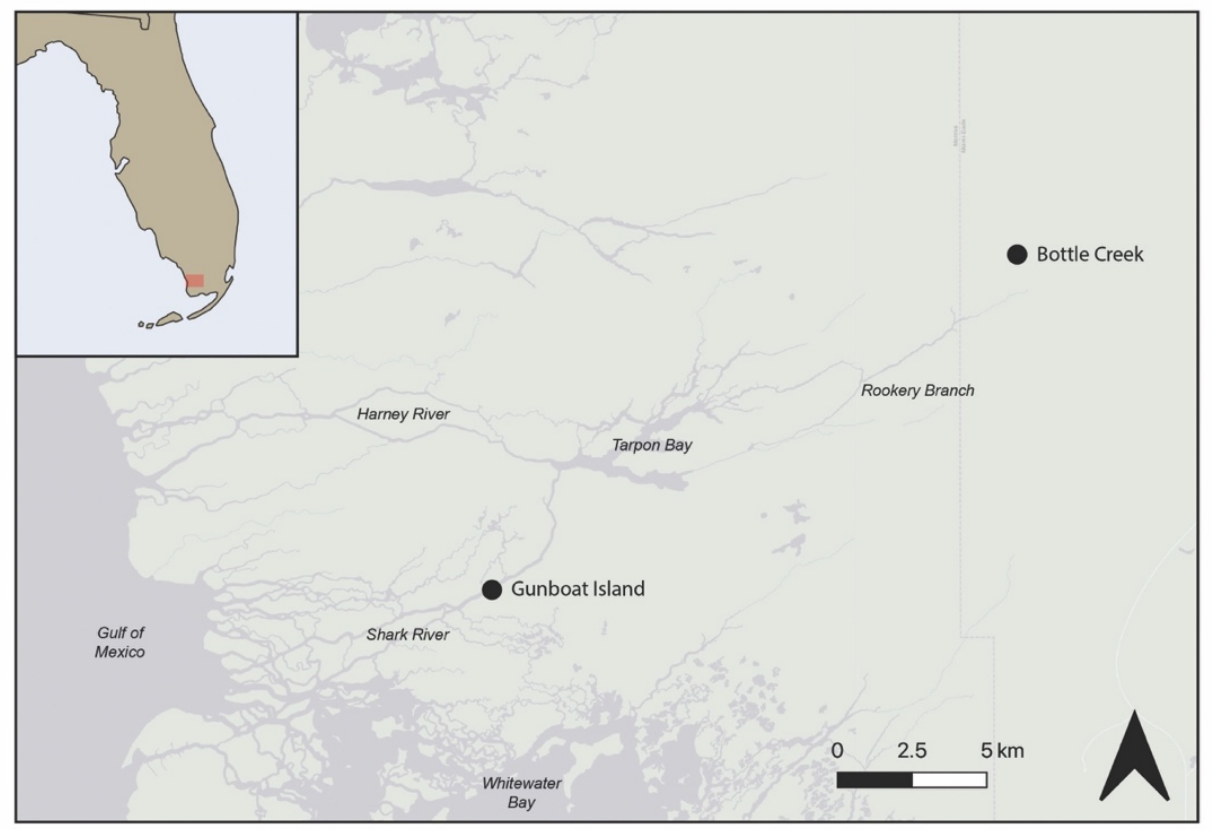


Figure 2: Home range size, defined by the area of the $95 \%$ utilization distribution, across the wet season, dry season, and breeding period for male, female, river, and marsh satellite-tracked American alligators (Alligator mississippiensis) in Shark River Estuary, Florida, USA (2013-2016).
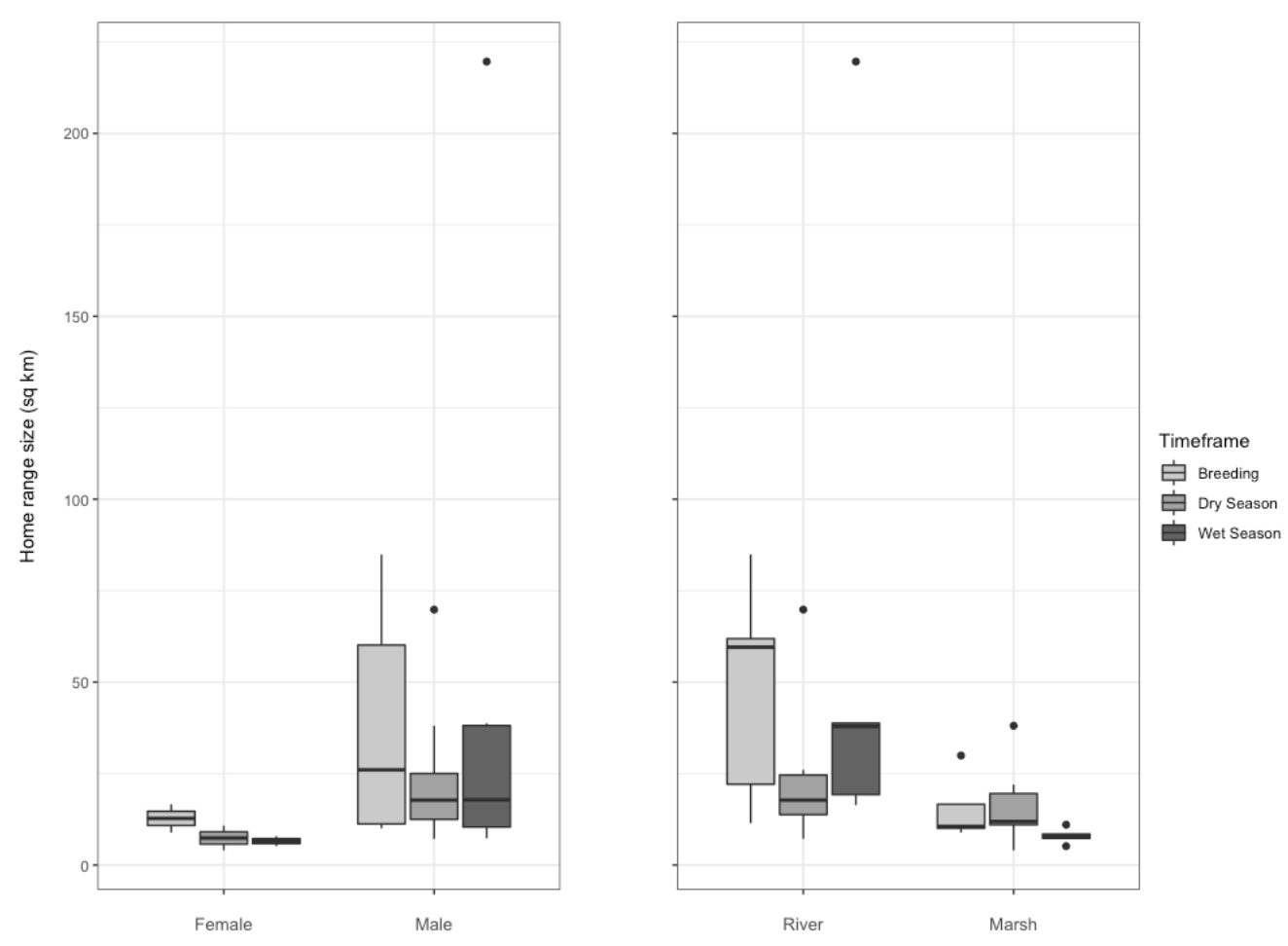
Figure 3: Home range size, defined by the area of the $95 \%$ utilization distribution, and mean movement activity (Brownian motion variance) compared across satellite-tracked American alligators (Alligator mississippiensis) of different total lengths and body conditions in Shark River Estuary, Florida, USA (2013-2016).
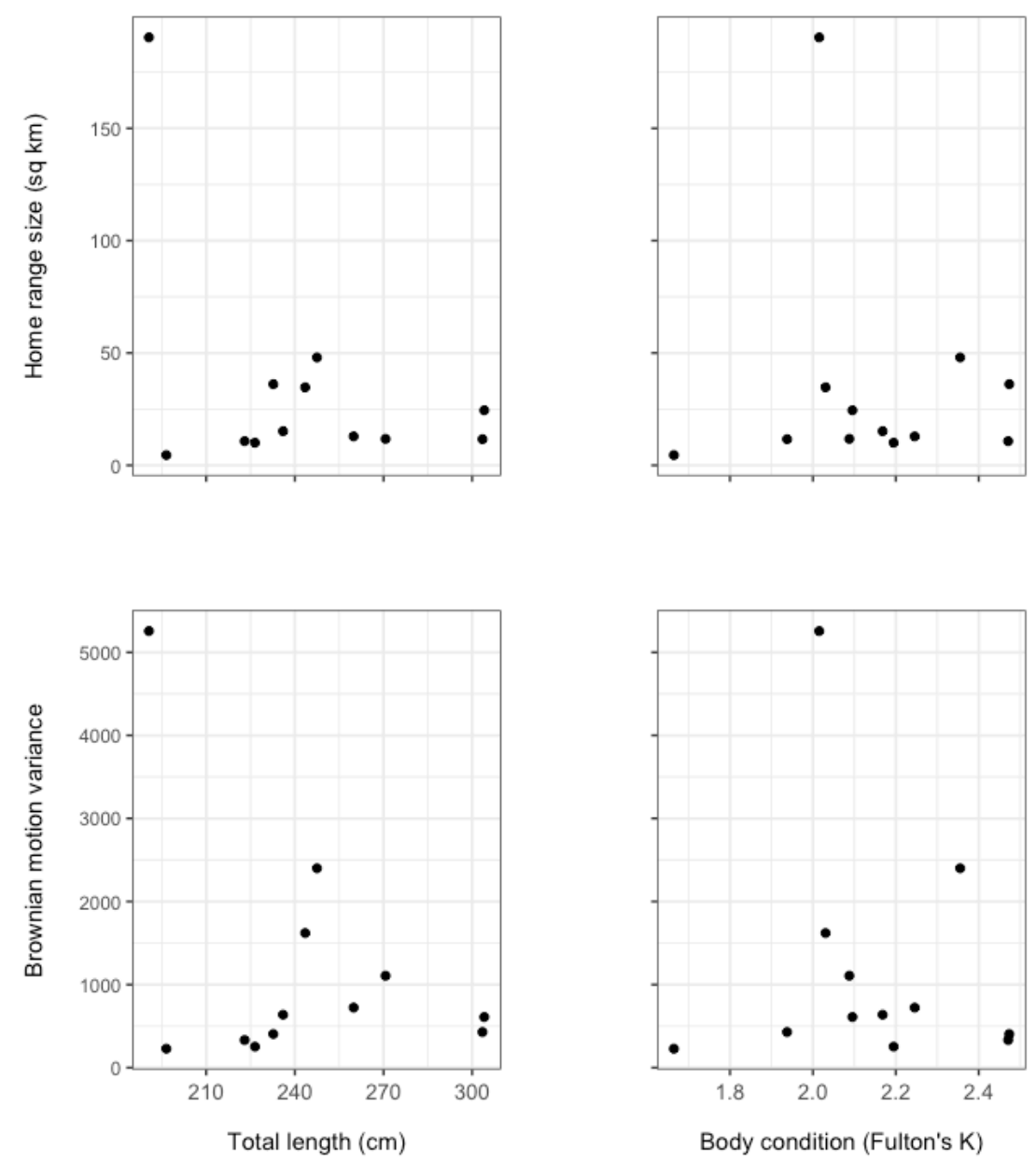
Figure 4: Movement activity (Brownian motion variance) of male, female, river, and marsh satellite-tracked American alligators (Alligator mississippiensis) compared across wet and dry seasons and breeding periods in Shark River Estuary, Florida, USA (20132016).
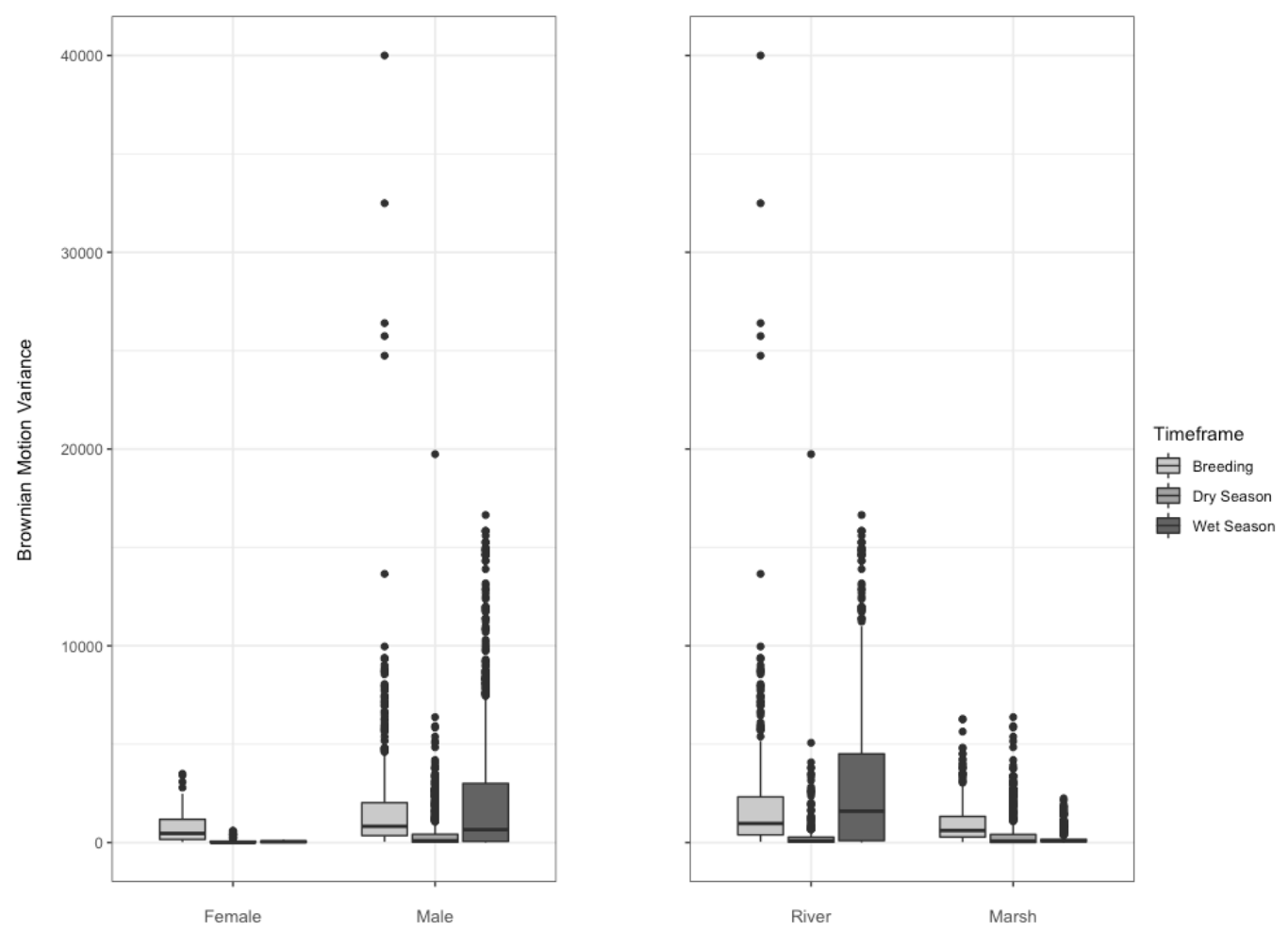
Table A1. Summary data for American alligators (Alligator mississippiensis) in Shark River Estuary, Florida, USA tracked using satellite telemetry (2013-2016) for which there were sufficient relocations.

\begin{tabular}{|c|c|c|c|c|c|c|c|c|c|c|}
\hline Individual & Tracking Period & $\begin{array}{l}\text { Tracking } \\
\text { Days }\end{array}$ & $\begin{array}{c}\text { Capture } \\
\text { Area }\end{array}$ & $\begin{array}{l}\text { Total } \\
\text { Length } \\
\text { (cm) }\end{array}$ & $\begin{array}{l}\text { Weight } \\
\text { (kg) }\end{array}$ & Sex & $\begin{array}{l}\text { Filtered } \\
\text { Locations }\end{array}$ & $\begin{array}{c}\text { Wet } \\
\text { Season } \\
\text { Locations }\end{array}$ & $\begin{array}{c}\text { Dry } \\
\text { Season } \\
\text { Locations }\end{array}$ & $\begin{array}{l}\text { Fulton's K } \\
\text { (Body } \\
\text { Condition) }\end{array}$ \\
\hline 123531 & $1 / 31 / 2013-1 / 2 / 2014$ & 336 & EST & 191 & 19 & M & 333 & 264 & 68 & 2.02 (Fair) \\
\hline 123532 & $1 / 17 / 2013-3 / 11 / 2014$ & 418 & EST & 233 & 42 & M & 401 & 214 & 186 & 2.47 (Excellent) \\
\hline 129516 & $10 / 28 / 2013-2 / 5 / 2014$ & 100 & EST & 236 & 37 & M & 62 & 6 & 55 & 2.17 (Good) \\
\hline 129517 & 10/28/2013-10/6/2014 & 343 & EST & 260 & 52 & M & 259 & 142 & 116 & 2.25 (Good) \\
\hline 129519 & $10 / 29 / 2013-10 / 22 / 2014$ & 358 & EST & 248 & 46 & M & 388 & 249 & 138 & 2.36 (Excellent) \\
\hline 133375 & $11 / 6 / 2013-10 / 30 / 2014$ & 358 & EST & 244 & 35 & M & 179 & 104 & 74 & 2.03 (Fair) \\
\hline 133376 & $11 / 4 / 2013-2 / 20 / 2014$ & 108 & TRS & 304 & 73 & M & 153 & 0 & 152 & 1.94 (Poor) \\
\hline 133377 & $11 / 6 / 2013-9 / 29 / 2014$ & 327 & TRS & 227 & 31 & $\mathrm{~F}$ & 155 & 68 & 86 & 2.19 (Good) \\
\hline 133378 & $11 / 4 / 2013-11 / 7 / 2014$ & 368 & TRS & 197 & 17 & $\mathrm{~F}$ & 291 & 101 & 189 & 1.66 (Poor) \\
\hline 133379 & $11 / 5 / 2013-10 / 17 / 2014$ & 346 & TRS & 304 & 72 & M & 222 & 107 & 114 & 2.10 (Fair) \\
\hline 133380 & 11/5/2013-9/13/2014 & 312 & TRS & 271 & 57 & M & 361 & 162 & 198 & 2.09 (Fair) \\
\hline 146674 & $2 / 4 / 2015-1 / 26 / 2016$ & 356 & TRS & 223 & 32 & M & 264 & 136 & 127 & 2.47 (Excellent) \\
\hline
\end{tabular}




\section{CHAPTER III}

\section{EFFECTS OF HYDROLOGY ON THE MOVEMENTS OF A LARGE-BODIED PREDATOR (ALLIGATOR MISSISSIPPIENSIS) IN A MANAGED-FRESHWATER MARSH}




\section{Abstract}

Wetlands are a dynamic environment for aquatic organisms impacted by predictable and unpredictable changes in hydrology. How are large-bodied abundant predators impacted by these changes, especially in context of wetland restoration? We investigated individual-level and environmental drivers of movement behaviors of American alligators (Alligator mississippiensis) using satellite telemetry in a managed freshwater marsh ecosystem of the Florida Everglades. Animals $(n=18)$ were tracked from April 2014 to November 2015 in Water Conservation Area 3 before, during and after a large-scale experimental water release. We used individual Brownian bridge movement models to estimate space use and movement activity of each animal across hydrological seasons and the breeding period. We also used selection ratios to investigate habitat selection and stable isotope analyses to infer dietary changes across seasons. Our results suggest that alligator activity nearly doubled after experimental water manipulation. Though individual animals did not change space use across seasons, movement activity was lower and $\delta^{15}$ Nitrogen isotopic values were higher in the dry season possibly reflecting easier foraging opportunities when marsh dry down concentrates prey. Alligators strongly selected canal habitats at the home range scale, but selected sawgrass habitats at the patch scale within home ranges. Animals may be using canals as foraging sites which have abundant prey year-round and shallow sawgrass habitats as spots for basking. We found that male alligators had three times higher movement activity rates and double the home range sizes of females. In addition, individual alligators used more space and, as a population, movement activity was over 2.5 times higher during the breeding period than outside this time. Larger animals had 
larger home ranges. However, we also found that poorer body condition animals had higher movement activity rates and larger home ranges, particularly in the wet season likely to access resources spread across the marsh. Based on our findings, ongoing restoration of water inflow and decompartmentalization will likely change the distribution and movement behavior of alligators.

\section{Introduction}

Wetlands are often dynamic exhibiting both predictable and unpredictable changes in hydrology. Most wetlands rely on seasonal pulses of rainfall and many depend on water management practices to maintain community structure and ecosystem function (Mitsch and Gosselink 2015; Trexler et al. 2005). Wetland ecosystems support a wide range of valued functions including water storage, flood protection, and water purification (Beerens et al. 2017). Wetlands also serve as sources of habitat and food, supporting high biodiversity and biomass relative to their global coverage (Mitsch and Gosselink 2015). On a global scale and over the last century, wetlands have been drained and hydrologic regimes have been modified leading to a loss of ecological functions, economic value, and renewable ecosystem services (Mitsch and Gosselink 2015; Zedler 2000). Wetland services are also under threat from changes in global climate, invasive species pressures, and non-point source pollution (Erwin 2009). Restoration of shallow water ecosystems remains an important goal for many regions and success relies on not only the redistribution of water, but also on aspects of water quality, water timing, and management of fish and wildlife populations (Zedler 2000). Biogeochemical, hydrological, and biodiversity responses to restoration have been well-documented in 
some aquatic systems; however, expected shifts in animal behavior after restoration efforts are rarely studied despite their potential to have important feedbacks on ecosystem function (Brusati et al. 2001; Armitage et al. 2007; Lindell 2008).

Seasonal, natural, and managed disturbances such as fire, drought, and flood characterize many wetlands. Effects of these disturbances on the environmental conditions faced by aquatic animals lead to behavioral changes both directly (i.e., responses to physical environmental changes) and indirectly (i.e., responses to changes in the distribution or abundance of food or predators). For instance, macroinvertebrate communities and recolonization in non-perennial streams of Victoria, Australia were directly affected by species-specific differences in tolerance and resilience traits (e.g., desiccation-resistant life stages and aestivation behavior within refuges) (Chester and Robson 2011). In another example, on the Mississippi River floodplain site-specific patterns of colonization decreased and extinction rates increased for marsh rice rats (Oryzomys palustris) with increased recent rainfall (van der Merwe et al. 2016). Thus, changes in hydrology led to decreased foraging patch quality and indirectly affected metapopulation dynamics for this semi-aquatic mammal (van der Merwe et al. 2016). Within highly altered habitats, populations may face scarcity and fluctuations in resources which may drive plasticity in foraging and movement decisions. For example, in natural sloughs and artificial canals of managed wetlands, Florida gar (Lepisosteus platyrhinchus) move more frequently and across greater distances during seasonal flooding and drydown than in timeframes of stable water depths (Parkos et al. 2015). Flooding allowed long-range dispersal from crowded refuges, but as water levels dropped fish returned (Parkos et al. 2015). The complexity and importance of behavioral 
responses of animals suggests that models to inform wetland management practices and to evaluate restoration efforts should include species-specific components that integrate environmental drivers such as hydrology with biological drivers such as demographics (Gawlik 2006).

Predators can exert considerable effects on the structure and function of aquatic ecosystems (Estes et al. 2016; Atkinson et al. 2017). Understanding drivers of the movements and distribution of species that have disproportionate ecological effects relative to their density, will allow us to better predict impacts of disturbances and environmental change on community and ecosystem dynamics. Crocodilians are dominant predators in numerous tropical and subtropical aquatic ecosystems. American alligators (Alligator mississippiensis) are the most abundant large-bodied predator in wetlands of the southeastern United States and can be found in diverse aquatic habitats in the Southeastern U.S. including coastal estuaries, freshwater marshes, swamps, inland reservoirs and lakes, and small stream drainages (Mazzotti and Brandt 1994). The alligator is widely regarded as a dietary generalist and has the potential to generate topdown effects (Nifong and Silliman 2013; Rosenblatt et al. 2015). Alligators have also been studied as physical ecosystem engineers (Kushlan 1974) and may be important mobile vectors of nutrients between terrestrial and aquatic systems or between different aquatic systems (Rosenblatt and Heithaus 2011; Subalusky et al. 2009). Despite being a primarily freshwater species, drivers of movement for alligators in freshwater wetlands (Subalusky et al. 2009; Strickland et al. 2016) have not been well-studied compared to coastal systems including estuaries (Rosenblatt and Heithaus 2011; Fujisaki et al. 2014, 2016) and coastal marshes (Joanen and McNease 1970, 1972). Generally, crocodilian 
movements are associated with thermoregulation, defense of territory, mate acquisition, and foraging (Lang 1987).

The Florida Everglades is a large wetland that has experienced major changes in freshwater inflow, hydroperiods, and nutrient enrichment as a result of anthropogenic land use changes since the late 1800s (Gawlik 2006; Sklar et al. 2005). Historically, the Everglades was a contiguous wetland with southward-oriented sheetflow towards the coast (Sklar et al. 2005). However, the system has been largely compartmentalized into marsh reservoirs separated by canals and levees, each section with a different water management plan. The freshwater marshes of the Florida Everglades are generally oligotrophic and water levels fluctuate from seasonal differences in rainfall in defined wet and dry and periods and annually with high and low rainfall years (Trexler et al. 2005). Current efforts to restore the Everglades have focused on recreating natural hydrological patterns by decompartmentalizing areas blocked by canals and levees (NASEM 2016). These actions are enacted within the Comprehensive Everglades Restoration Plan (CERP) to restore the natural hydrology of the Everglades. The Decompartmentalization and Sheet Flow Enhancement Physical Model (DPM), installed in October 2013, is a scientific field-scale test of specific plans within CERP (NASEM 2016). One important piece of DPM involved controlled water deliveries released early in the dry season of 2014. These DPM water deliveries were a large-scale experimental manipulation to investigate impacts of restoration and restore flowing water to an area impounded for more than 60 years (NASEM 2016). The ecological impacts of major restoration efforts such as these are relatively unstudied (but see Ontkos 2018). Overall, historic changes in hydrology are thought to have caused declines in some species' 
abundances and distributions (Sklar et al. 2005), but several restoration scenarios predict increases in many aquatic fauna including in the abundance of small fish and occurrence of wading birds in the Everglades (Beerens et al. 2017).

Alligators are indicators for restoration of Everglades ecosystems because of their important roles as predators and ecosystem engineers along with their relationship to local hydrological patterns (Mazzotti et al. 2009). Therefore, understanding aspects of their movement behaviors could be significant in determining the impact of environmental change on wetland ecosystems. Our current knowledge of how large-scale changes impact alligator movements and distribution across the landscape is inadequate to develop effective restoration plans. Important questions remain such as what factors drive alligator movement decisions, at what scales are decisions made, and what are the behavioral impacts of hydrology and wetland restoration? To address these questions, we used satellite telemetry and an individual-based movement modelling framework to quantify the movements of American alligators across a range of environmental conditions in space and time in the oligotrophic freshwater marshes of the central Florida Everglades. We tracked both sexes over a range of adult size classes. Our main objective herein was to investigate behavioral drivers and assess the impact of seasonal- and anthropogenically-induced hydrological changes, including the experimental water deliveries within DPM, on the movement behavior of alligators in a freshwater marsh.

\section{Methods}

Study area

Animals were tagged within Water Conservation Area 3 (WCA 3) in the central 
Everglades in two areas: 3A and 3B (Figure 1). The WCA 3 is a $2442 \mathrm{~km}^{2}$ area used for wildlife management, flood protection, recreation, and water supply with surrounding man-made levees and canals. Organic peat soils overlay limestone bedrock and marsh water levels fluctuate seasonally, but the southern portion of $3 \mathrm{~A}$ is excessively flooded (Bruland et al. 2006). Macrophytes, periphyton, Utricularia spp., and other floating plants are abundant primary producers. The WCA 3 and other Everglades marshes are often mosaics of spikerush-dominated wet prairies (Eleocharis spp.) and shallower ( 20 cm less) sawgrass (Cladium spp.) stands (Jordan et al. 1997). Water levels throughout WCA 3 are primarily controlled by rainfall (Julian 2013), but 3A exhibits a longer hydroperiod with higher average water levels than $3 \mathrm{~B}$, which is more prone to drying. The area exhibits strong seasonal pulses of rainfall in the wet season (May through October) (Duever et al. 1994). Controlled water deliveries from the S-152 culverts affected water levels and flow in the area between the L67-A and L67-C canals (known as "the gap") and WCA 3B (NASEM 2016; USGS 2019). These experimental releases were expected to have little to no impact on WCA 3A, but water levels did rise after the release in 3A along with 3B and the gap (USGS 2019; see appendix Figure A1). Specifically, the water release lasted 86 days from 4 November 2014 to 29 January 2015 (USGS 2019). Over this time period, discharge averaged $7.7 \pm 0.4 \mathrm{~m}^{3} / \mathrm{s}$ ranging from 6.2 to $8.5 \mathrm{~m}^{3} / \mathrm{s}$ (USGS 2019).

\section{Alligator capture and sampling}

Alligators were captured using a pole and snare technique from an airboat. Highpowered spotlights were used at night to find alligators by looking for reflective eyeshine 
and then slowly approaching the targeted animal. For each captured alligator, we recorded sex from cloaca examination (Chabreck 1963) and measured total length, tail girth, head length, snout vent length, and weight using a spring scale. After collection of tissues for stable isotope analysis, animals were released at their capture locations. We calculated Fulton's body condition factor (K) using weight (M) and snout-vent length $(\mathrm{SVL})$ as $\mathrm{K}=\mathrm{M} / \mathrm{SVL}^{3} \times 10^{5}$ (Brandt et al. 2016). Alligators were considered as being in poor $(\mathrm{K} \leq 1.95)$, fair $(1.95<\mathrm{K} \leq 2.10)$, good $(2.10<\mathrm{K} \leq 2.27)$, or excellent condition $(\mathrm{K}$ > 2.27) (Brandt et al. 2016; Mazzotti et al. 2009). When assessing correlations between body size and body condition metrics, we used Spearman's rank coefficient. We used exact Wilcoxon rank sum tests when comparing total length and body condition between males and females and between alligators captured in WCA 3A and WCA 3B as a result of low sample sizes in each group.

\section{Telemetry}

A satellite transmitter (Spot 5; Wildlife Computers; Redmond, Washington, USA) was attached to the nuchal scutes of each sexually mature alligator. For attachment, we disinfected the nuchal rosette area with betadine and subsequently injected lidocaine, a local anesthetic. A separate observer monitored breathing and pupils of the animal. Two stainless steel needles (230 $\mathrm{mm}$ by $3 \mathrm{~mm}$ diameter) were forced through the skin on the posterior side of the rosette, and with the aid of pliers, run subcutaneously under the osteoderms of the rosette to the anterior side. We drew two strands of stainless-steel wire (breaking strain $41-68 \mathrm{~kg}$ ) that had been soaked in 100\% ethanol (each approx. $50 \mathrm{~cm}$ in length) until they protruded through the skin near the rosette. We constructed a mold of 
marine epoxy the width of the transmitter along the top of the rosette. The transmitter was positioned on this bed and the subcutaneous wires were threaded back through the attachment loops on both sides of the transmitter, tightened and crimped with aluminum or lead sleeves that locked the wires together. We finally used additional epoxy to complete the mold of the rosette, maximizing the surface area of contact between the rosette and the mold, with the upper surface shaped into a dome encasing the transmitter (Brien et al. 2010).

These tags transmit signals to the Argos satellite array when the animal surfaces and the sensor detects that it is dry. We programmed the tags to transmit a maximum of 250 locations per day checking for a dry sensor every 0.25 seconds with a fast repetition rate of 44.5 seconds and a slow repetition rate of 89.5 seconds, switched on after 10 successive dry transmissions. At these settings, the estimated battery life range was between 400-540 days. The tags were scheduled to transmit every hour of every deployment day. We used the Argos Low Earth Orbit global satellite-based location and data collection system for satellite tracking. Argos position estimates are grouped into six location classes assigned by accuracy: class 3 (accurate within $250 \mathrm{~m}$ ), class 2 (250 to $500 \mathrm{~m}$ ), class 1 (500 to $1,500 \mathrm{~m})$, class 0 (more than 1,500 m), and classes A and B (unbounded accuracy estimation). Using the Douglas filtering method for Argos satellite data, we filtered locations using possible animal speed and accuracy retaining only class 3 and 2 locations, the two most accurate categories, for analyses and discarded other locations. Within the filtered dataset, duplicate timestamps within one minute were removed with the best class location retained. Animals with fewer than 40 total filtered relocations were omitted. Nearly all locations (>98\%) were obtained between sunset and 
sunrise. We removed daytime locations from future analyses to avoid bias. Average daily fix rate (calculated as number of days with a successful relocation divided by total number of days within the tracking period) for all tagged animals used in subsequent analyses including only filtered locations was $30 \pm 15 \%$.

\section{Stable isotope analysis}

We drew $5 \mathrm{~mL}$ of blood using a syringe and 21-gauge needle from the dorsal sinus cavity. We immediately used a centrifuge spinning at $3000 \mathrm{rpm}$ for 30 seconds to separate the blood into red blood cells and plasma. We also clipped a scute from behind the tail base. These samples were immediately placed on ice and frozen until they were homogenized and dried. Lipids were not extracted because removal does not significantly affect alligator isotope values (Rosenblatt and Heithaus 2013). Samples were analyzed at the Stable Isotope Laboratory at Florida International University where variation among standards was 0.04 and $0.09 \%$ $\pm \mathrm{SD}$ for $\delta^{13} \mathrm{C}$ and $\delta^{15} \mathrm{~N}$, respectively. Isotope samples were collected from five animals in late April and early May representing the dry season and 12 animals (eight with sufficient relocations for further spatial analyses) in late October and early November representing the wet season. Blood plasma and scutes of juvenile alligators have $\delta^{13} \mathrm{C}$ half-lives of $c a .60$ and 150 days and $\delta^{15} \mathrm{~N}$ half-lives of $c a$. 60 and 100 days, respectively (Rosenblatt and Heithaus 2013). We compared carbon and nitrogen values of both tissues across sexes and seasons using exact Wilcoxon rank sum tests. 


\section{Environmental data}

We obtained daily weather data including precipitation and air temperature through National Oceanic and Atmospheric Administration's National Centers for Environmental Information data access web portal (NOAA 2019). Within the tool, we selected the closest weather station to our study site, Miami International Airport, for which there was sufficient data. We then used the "suncalc" and "maptools" R packages to obtain proportion of the moon illuminated and solar position by hour (Thierurnmel and Elmarchraoui 2019; Bivand and Lewin-Koh 2019). Hydrological data were obtained from the United States Geological Survey/National Park Service Everglades Depth Estimation Network database (USGS 2019). We used Site EDEN 8 for relocations in WCA 3A, Site 71 for relocations in WCA 3B, and Site 69E for relocations in the gap (USGS 2019).

\section{Movement model and space use estimator}

We used dynamic Brownian bridge movement models in the "move" R package (Kranstauber et al. 2019) to study the movement patterns and space use of individual animals (Kranstauber et al. 2012). These models use the time, angle, and distance between two locations to interpolate intermediate points, calculate motion variances along a path, and estimate density surfaces. We incorporated the estimated maximum error of each location corresponding to its assigned location class [i.e., class 3 (250 m) and class $2(500 \mathrm{~m})]$. In addition, we used a margin of 11 locations and 31 as a window size (Kranstauber et al. 2012). The model results produce a UD, or utilization

distribution, which is a probability distribution that is useful in predicting the relative 
intensity of use of cells (i.e., patches) within an animal's home range (Fieberg and Kochanny 2005). The 95\% UD contour area is expected to approximate the overall home range of the animal and the 50\% UD contour area describes its area of core use (Kei et al. 2010; Said and Servanty 2005). Multi-annual, seasonal, and breeding period dynamic Brownian bridge movement models and UD estimations were only performed for animals with 40 or more locations within the timeframe. We defined the breeding period as courtship and mating only which occurs April 1-June 1 each year (Mazzotti and Brandt 1994). Nesting females also spend time building a nest and protecting young for months to years after the breeding period but given that we do not know if or which alligators were nesting, we did not parse out a separate period (Rootes and Chabreck 1993; Joanen and McNease 1970). To evaluate the correlation between total length and range sizes as well as body condition and range sizes, we used Spearman's rank coefficient test. We also used exact Wilcoxon rank sum tests to compare overall, seasonal, and breeding range sizes between males and females. We used a paired two-sample Wilcoxon test to compare seasonal and breeding period range sizes across animals.

The model also estimates motion variance along the pathway using step length, turning angle, and speed between two relocations (Byrne et al. 2014). Changes in motion variance indicate changes in an animal's activity and behavioral state where higher values imply increased activity and/or irregular movement paths and lower values are coupled with decreased activity and/or regular paths (Kranstauber et al. 2012; Byrne et al. 2014). To compare movement activity immediately before and during the experimental water release, we used as asymptotic Wilcoxon rank sum test. We restricted the data to only include the 30 days before and the 30 days during the water release to limit any 
confounding effects of seasonality. We also compared female and male movement activity along with breeding period and seasons using the same method. We used Spearman's rank coefficient to test the correlation of movement activity to gage height, body condition, and body size.

\section{Habitat selection}

We obtained 2014-2016 land cover and land use data from the South Florida Water Management District (South Florida Water Management District 2019). The dataset was prepared by photo interpretation from aerial photography, classified using an internal cover and use classification system, and verified with ground truthing (South Florida Water Management District 2019). We clipped the dataset to the study area using a minimum bounding polygon of all relocations plus a $5 \mathrm{~km}$ buffer to define the study site. We created a classified raster of $30 \mathrm{~m}$ resolution containing the dominant habitat in each pixel then exported as a point grid. We combined and collapsed several land cover and use categories to yield five habitat classes: 1) canal, 2) sawgrass marsh, 3) spikerush

marsh, 4) woody vegetation (shrubs and trees), and 5) mixed emergent aquatic vegetation including broadleaf and floating plants. We performed geospatial analyses and created the habitat map using ArcMap 10.6.1 (Environmental Systems Research Institute; Redlands, California, USA). We determined the habitat class for each relocation and calculated the proportion of each habitat within each animal's range. We used Manly selection ratios to evaluate habitat selection within a use-availability design at two spatial scales: second order, or the selection of home range (used) within our study area (available), and third order, or the selection of patches (used) within an animal's home 
range (available) (Manly et al. 2002; Thomas and Taylor 1990). Selection ratios less than 1 indicate avoidance and greater than 1 signifies preference with the deviance from 1 explaining the strength of selection (Manly et al. 2002). We used 95\% confidence intervals to designate preference and avoidance if the CI did not overlap 1; if the CI overlapped 1, then the habitat was neither preferred or avoided. We used a Chi-squared test to compare habitat use between pre- and during experimental water releases using only the 60 days before and the first 60 days of release, wet and dry seasons, and breeding and non-breeding periods. We also used a Chi-squared test to compare mean habitat use between males and females. A relationship between the calculated motion variance and habitat class can reveal an association between animal behaviors in specific habitats (Kranstauber et al. 2012). We used a Kruskal-Wallis test, to determine if such a relationship existed. We performed all statistical analyses using $\mathrm{R}$ (Mac version 3.6.1; R Foundation for Statistical Computing; Vienna, Austria). We reported means with \pm 1 standard deviation (SD).

\section{Results}

We deployed six satellite tags to alligators in the South Florida Water Conservation Area 3A and 12 tags in WCA 3B. The first group of animals were tagged in April 2014 and the last transmission occurred in November 2015 (Table A1). The final filtered dataset for movement analyses included 1,886 locations of 14 animals with a mean of $135 \pm 92$ locations per animal (range $=42-280$; Table A1).

Body size measurements were highly correlated (all Spearman's rho $(\mathrm{P})>0.73$ ); thus, we used only total length as a proxy for body size in subsequent analyses. Alligator 
total length averaged $2.0 \mathrm{~m}$ and ranged from 1.7 to $2.6 \mathrm{~m}$ (Table A1). Males $(n=4)$ had a mean total length of $2.4 \pm 0.2 \mathrm{~m}$ whereas females $(n=14)$ had a smaller average length of $1.9 \pm 0.1 \mathrm{~m}(\mathrm{~W}=54, p<0.01)$. Fulton's condition factor ranged from 1.08 to 2.23 with a mean of 1.92 . Half (50\%) of the tagged animals were in poor condition, $29 \%$ in fair, $21 \%$ in good, and none exhibited excellent body condition (Table A1). Fulton's condition factor was not correlated with total length $(\mathrm{P}=-0.23, S=1190.5, p=0.36)$. In addition, we found no difference in the body conditions of alligators caught in $3 \mathrm{~A}$ versus $3 \mathrm{~B}$ and the gap $(\mathrm{W}=36, p=1)$ or between males and females $(\mathrm{W}=27, p=0.9)$.

Mean home range size was $7.0 \pm 3.8 \mathrm{~km}^{2}\left(\right.$ range $\left.=1.1-14.4 \mathrm{~km}^{2}\right)$ and mean core use area was $1.0 \pm 0.5 \mathrm{~km}^{2}\left(\right.$ range $\left.=0.2-1.7 \mathrm{~km}^{2}\right)($ see Table 1$)$. All animals had one centralized area of activity within their home range except animal x142358 who had two centers of activity. We detected no differences between alligators in $3 \mathrm{~A}$ and $3 \mathrm{~B}$ for home range sizes $(\mathrm{W}=17, p=0.70)$ or core use area sizes $(\mathrm{W}=14, p=0.45)$. Male alligators had larger 95\% UD areas averaging $11.3 \pm 2.4 \mathrm{~km}^{2}(\mathrm{~W}=39, p<0.01)$, than females averaging $5.3 \pm 2.7 \mathrm{~km}^{2}$, but we did not detect a difference in $50 \% \mathrm{UD}$ areas $(\mathrm{W}=34, p=$ 0.05). Males had larger wet season $95 \% \mathrm{UD}$ areas $(\mathrm{W}=23, p=0.01)$ and $50 \% \mathrm{UD}$ areas $(\mathrm{W}=24, p=0.01)$ than females (Figure 2). In addition, males had larger dry season 95\% $\mathrm{UD}$ areas $(\mathrm{W}=16, p=0.01)$ and $50 \% \mathrm{UD}$ areas $(\mathrm{W}=15, p=0.03)$ than females. Though there was a trend towards males having larger breeding period home ranges than females, these results were not significant $(\mathrm{W}=18, p=0.06)$. Total length was positively correlated with home range size $(\mathrm{P}=0.63, S=166.7, p=0.02)$, but not core use area $(\mathrm{P}=$ $0.33, S=303.3, p=0.24$ ) (Figure 3 ). Total length was also positively correlated with 
breeding period home range size $(\mathrm{P}=0.90, S=11.5, p<0.001)$, breeding period core use area, wet season home range size $(\mathrm{P}=0.79, S=34.4, p=0.01)$, wet season core use area, and dry season home range size $(\mathrm{P}=0.76, S=20.6, p=0.03)$, but not dry season core use area $(\mathrm{P}=0.57, S=35.7, p=0.14)$. Body condition was negatively correlated with home range size $(\mathrm{P}=-0.57, S=714, p=0.04)$ and core use area $(\mathrm{P}=-0.58, S=720, p=0.03)$. Body condition was not correlated with breeding period home range size $(\mathrm{P}=-0.63, S=$ $196, p=0.08)$ or core use area. Even though body condition was not correlated with dry season home range size $(\mathrm{P}=0.07, S=78, p=0.88)$, dry season core use area, or wet season core use area, it was negatively correlated with wet season home range size ( $\mathrm{P}=$ $0.65, S=272, p=0.05)$. Individual animals did not differ in seasonal space use for $95 \%$ $\mathrm{UD}$ areas $(\mathrm{V}=18, p=0.58)$ or $50 \% \mathrm{UD}$ areas $(\mathrm{V}=15, p=0.94)$ across the wet and dry seasons. However, individual animals did have larger 95\% UD areas ( $\mathrm{V}=44, p<0.01)$ and $50 \% \mathrm{UD}$ areas $(\mathrm{V}=45, p<0.01)$ during the breeding period compared to the nonbreeding period.

Movement activity increased in the first 30-days of the water release compared to the 30-days immediately before, averaging $77 \pm 77$ and $40 \pm 16$, respectively (Figure 4 ; $\mathrm{W}=1349, p=0.04)$. Though, water level and movement activity were negatively correlated $(\mathrm{P}=-0.43, S=819180000, p<0.001)$. We also saw that movement activity was positively correlated with average daily temperature $(\mathrm{P}=0.20, S=484159004, p<$ 0.001). Movement activity was not correlated with the fraction of the moon illuminated $(\mathrm{P}=0.03, S=587883933, p=0.30)$ or daily rainfall $(\mathrm{P}=0.04, S=578327795, p=0.10)$. Mean activity for animals in 3B averaged $496 \pm 770$ and was not different than in 3A, which averaged $598 \pm 916(\mathrm{~W}=85326, p=0.62)$. Activity was higher for males 
compared to females ( $\mathrm{W}=417010, p<0.001)$, which averaged $653 \pm 934$ compared to $178 \pm 338$, respectively (Figure 5). At the population-level, mean movement activity was greater during the breeding period $(912 \pm 1226)$ compared to the non-breeding period $(336 \pm 529)(\mathrm{W}=322460, p<0.001)$ and greater in the wet season compared to the dry season $(\mathrm{W}=346560, p<0.001)$. Body condition and movement activity were negatively correlated though the correlation coefficient was low $(\mathrm{P}=-0.058, S=638780000, p=$ 0.02) (Figure 3). However, body size was positively correlated with movement activity (P $=0.349, S=393210000, p<0.001)$.

Males and females did not differ in plasma $\delta^{13} \mathrm{C}(\mathrm{W}=35, p=0.50)$ or $\delta^{15} \mathrm{~N}$ values $(\mathrm{W}=28, p=1)$ (Figure 6). Similarly, males and females did not differ in scute $\delta^{13}$ $\mathrm{C}(\mathrm{W}=32, p=0.55)$ or $\delta^{15} \mathrm{~N}$ values $(\mathrm{W}=1.5, p=0.11)$, but only one female was grouped with males with low $\delta^{15} \mathrm{~N}$ values (Figure 6). For blood plasma tissue, $\delta^{13} \mathrm{C}$ values averaged $-27.5 \pm 0.9 \%$ in the wet season and $-27.7 \pm 1.0 \%$ in the dry season and were not different across seasons $(\mathrm{W}=38, p=0.89)$. For plasma, $\delta^{15} \mathrm{~N}$ values averaged $7.3 \pm 0.8 \%$ in the wet season and were comparatively higher in the dry season averaging $8.3 \pm 0.6 \%$ o $(\mathrm{W}=10, p=0.01)$. For scute tissue, $\delta^{13} \mathrm{C}$ values averaged $-25.5 \pm 1.0 \%$ in the wet season and $-25.8 \pm 0.9 \%$ in the dry season and were not different across seasons $(\mathrm{W}=36, p=0.57)$. However, $\delta^{15} \mathrm{~N}$ scute values averaged $8.2 \pm 0.8 \%$ in the wet season and were comparatively higher in the dry season averaging $9.1 \pm 0.5 \%$ o $(\mathrm{W}=9, p=$ $0.01)$.

Sawgrass marsh covered $50.7 \%$ of the study area, followed by spikerush marsh (43.6\%), woody vegetation (3.5\%), mixed emergent vegetation $(1.9 \%)$, and canal $(0.3 \%)$. 
Animals were relocated most often in sawgrass marsh (59.8\%), then spikerush marsh (33.2\%), trailed by emergent vegetation (3.4\%), woody vegetation (3.2\%), and canal $(0.4 \%)$. However, the most abundant habitat type within home ranges across animals was spikerush marsh (30.6\%), followed by sawgrass marsh (28.3\%), woody vegetation (21.0\%), canal (14.3\%), and emergent vegetation (5.8\%). We saw no shift in population level habitat selection within the first 60 days during water releases compared to the 60 days before water releases $\left(\chi^{2}=20, \mathrm{df}=16, p=0.22\right)$. In addition, there was no detectable relationship between motion variance and habitat type $\left(\chi^{2}=8.1, \mathrm{df}=4, p=\right.$ 0.09). Analysis of second-order habitat selection, or selection of home range within the study area, showed that animals at the population level preferred canal habitat within their home ranges (Figure 7). Animals also had a preference for home ranges composed of sawgrass marsh and woody vegetation habitats (Figure 7). Spikerush marshes and mixed emergent vegetation were avoided within home ranges compared to their availability in the study area (Figure 7). General patterns of preference and avoidance were mirrored in the wet and dry seasons, although there was a difference in habitat composition between seasons $\left(\chi^{2}=10, \mathrm{df}=4, p=0.04\right)$ with $13 \%$ composition of canal within home range and $10 \%$ emergent vegetation for the dry season compared to $17 \%$ and $7 \%$, respectively, for the wet season (Table 2). We also saw that the selection of home ranges did not change between the breeding and non-breeding periods $\left(\chi^{2}=10, \mathrm{df}\right.$ $=6, p=0.13$ ) and mimicked the overall pattern (Table 2). Third-order habitat selection, or the selection of patches within the home range, revealed that at the population level, animals preferred sawgrass marshes, but avoided woody vegetation and canal habitats compared to the availability of these habitats within their home ranges (Figure 7). Patches 
of spikerush marshes and emergent vegetation habitats were neither selected nor avoided in their home ranges (Figure 7). These habitat selection patterns applied for the wet season and outside the breeding period. Though in the dry season and breeding period there was preference for sawgrass marshes and selection against mixed emergent vegetation, woody vegetation, and canal with no selection for or against spikerush marshes. We did not see a difference in habitat use between males and females at either scale (second-order, $\chi^{2}=20, \mathrm{df}=16, p=0.22$; third-order, $\chi^{2}=20, \mathrm{df}=16, p=0.22$ ).

\section{Discussion}

Our results suggest that large-scale changes in hydrology and water management were drivers of movement behavior of alligators. Beyond finding differences in movements with seasonal changes in hydrology, we also found that alligator movement activity increased immediately after experimental water deliveries nearly doubling the activity rates seen before the release. Water levels rose throughout WCA 3 as a result of the release and certainly impacted the normal dry season drydown cycle. Changes in water levels resulting from these deliveries might have influenced availability, or more so suitability, of particular habitats based on altered prey distribution and thermal buffering capacity of water for alligators. In wetlands, fluctuating hydrological conditions can provide new access to patches, remove access to low-water habitats, alter physical parameters (e.g., oxygen availability and temperature) within patches, and impact local prey availability (Trexler et al. 2005; DeAngelis et al. 1997; Goss et al. 2014). We did not find differences in broad habitat categories selected before and during the release. However, we still suspect that increased micro-habitat suitability and ease of movement 
in water with higher water levels, led alligators to increase activity and move throughout marsh habitats more freely (Fujiskai et al. 2011). Florida gar (Lepisosteus platyrhincus), another large-bodied Everglades freshwater marsh predator, increase displacement rates when water levels rise and drop (Parkos et al. 2015). These movements are thought to be largely in response to the movements of prey (i.e., smaller fish) traveling back and forth between marsh and refuge habitats to deal with flooding and drying cycles (Goss et al. 2014; Parkos et al. 2015). However, fluctuating hydrology may not influence general habitat selection patterns of predators. For instance, large-bodied predatory fish in the Everglades still remain close to highly selected habitats like canals even while exhibiting increased movement rates when water levels change (Parkos et al. 2015; Ontkos 2018).

Our results are also consistent with other studies of alligator activity. For instance, in a coastal marsh of southwestern Louisiana, alligators increased movement activity to respond to rising water levels from excessive rainfall and storm tides over a four-year study (Chabreck 1965). In addition, another study showed that alligators responded to anthropogenic water withdrawals by concentrating in deeper water areas of a managed reservoir in east Texas (Webb et al. 2009). Interestingly, in our work, movement activity increased when water levels dropped even though movement activity was higher in the wet than dry season, and the release led to increased movement activity along with higher water levels. One likely explanation for this pattern is that the beginning of the breeding period where some of the highest movement activities occurred corresponds to low water levels (i.e., the end of the dry season). In addition, water levels over each season rise and fall (i.e., exhibit a parabolic curve when plotted over time) meaning that direct relationships are difficult to detect. 
For individuals, ranges sizes were consistent across seasons indicating that animals are fairly consistent in the amount of space needed even when seasonal resource distributions differ. In general, animals also did not change their habitat selection at the home range scale across seasons. Selection was similar at the finer spatial scale across seasons; however, animals avoided patches of mixed emergent vegetation in the dry season but had no selection for or against in the wet season. During the dry season some floating and broadleaf macrophytes may die, limiting structure offered to fish and thus prey. Also, movement may be easier in deeper slough habitats compared to ridges, which may have thick vegetation and dry out in the dry season. Alligator habitat selection within their home range may reflect these seasonal changes. One limitation of the study is that we were not able to obtain seasonal or sub-seasonal land cover imagery and instead used a static habitat map. Habitat availability likely changed in some areas of our study area between seasons. We selected five broad ecologically relevant habitat categories for our study which may have been general enough to limit any seasonal bias. However, future studies using dynamic habitat models and detailed environmental information will provide additional insight into seasonal drivers of movement. Across both seasons, alligators selected sawgrass marsh habitat at both scales and avoided spikerush marshes when selecting home ranges. Sawgrass habitats are typically shallower and support lower densities of fish compared to spikerush habitats (Chick et al. 2004; Trexler et al. 2002; Jordan et al. 1997). Given the lack of prey and difficulty of prey capture in thick sawgrass stands, alligators may use these habitats at night for thermoregulation and rest. Though we have no way of determining if any of our tracked animals were nesting females, they would use shallow and terrestrial habitats such as clearings in sawgrass stands or woody 
vegetation to nest. Alternatively, complete exposure of the dry sensor of the tags is likely greater for shallow sawgrass stands leading to more transmissions and detections compared to the other deeper water habitats.

Alligator activity, in other studies, peaks during spring courtship and mating and tapers off into the late fall with winter being the least active season for both sexes (Joanen and McNease 1970; McNease and Joanen 1974, Goodwin and Marion 1979). Compared to studies in more northern latitudes, alligators in the Shark River Estuary of the Everglades, for instance, exhibit similar movement rates across seasons, even though some animals have larger winter dry season ranges than the rest of the year (Rosenblatt et al. 2013). For our freshwater marsh alligators, movement activity was lower in the dry season compared to the wet season. Studies of alligator diets in the freshwater Everglades are limited (Barr 1997). However, in general, adult alligators are opportunistic predators and eat vertebrates including fish, mammals, birds, reptiles, and amphibians and invertebrates, particularly mollusks and crustaceans, which can make up a significant portion of their diets (Delany and Abercrombie 1986; Barr 1997; Rosenblatt et al. 2015). High prey availability in refuge habitats like canals was likely the primary facilitator for the sedentary tactic in the dry season. Deep-water alligator ponds, solution holes, and canals help diminish the severity of drydown effects and provide refuge for aquatic animals (DeAngelis et al. 1997; Parkos et al. 2011; Rehage and Loftus 2007). Compared to marsh habitats in the dry season, fish and invertebrate communities change and increase in density in the immediate proximity of alligator holes and canals (Kushlan 1974; Rehage and Trexler 2006; Parkos et al. 2011). However, these refuges are not without their own source of danger including oxygen depletion, increased disease 
susceptibility, limited escape, and higher predator risk (DeAngelis et al. 1997; Dorn et al. 2006). Studies of activity and energetics for crocodilians are limited (e.g., Bugbee 2008; Watanabe et al. 2013; Nifong et al. 2014), but the temporal and spatial scales that crocodilians are capable of managing their energy budgets are likely large given their capacity to go long periods of time (> six months) without eating (e.g., Lance 2003) and occasional long-distance movements (e.g., Rosenblatt and Heithaus 2011). In our study, $\delta^{13} \mathrm{C}$ isotopic values were not different across seasons, but $\delta^{15} \mathrm{~N}$ values were consistently higher in the dry season than in the wet season. This could mean that alligators were feeding at a higher trophic level throughout the dry season compared to the wet season or that the trophic baseline shifted in the dry season by the addition of higher trophic level species in refuge habitats. Given that the dry season concentrates many fishes and invertebrates, larger and higher trophic level prey items such as piscivorous fish may be preferable and consumed at a higher rate by alligators. Another study in the same study system, but a decade earlier found that eastern mosquitofish (Gambusia holbrooki) and riverine grass shrimp (Palaemonetes paludosus) had elevated trophic positions in the dry season as well (Williams and Trexler 2006). However, Williams and Trexler (2006) were also unable to determine if the changing trophic positions was related to diet shift towards higher trophic level prey, the addition of lower trophic level species, or both. Another complication, shared by other studies of dietary inference from stable isotopes on crocodilians, is that alligators are capable of long periods of time ( $>$ six months) without eating and living off energy reserves from past meals which may complicate inferring the temporal resolution of diet from isotopes (Lance 2003; Rosenblatt and Heithaus 2013). For our alligators across both seasons and 
tissues, estimated $\delta^{15} \mathrm{~N}$ values ranged from $\sim 6$ to $10 \%$. Williams and Trexler (2006) estimated mean $\delta^{15} \mathrm{~N}$ values for eastern mosquitofish (Gambusia holbrooki) and Florida gar (Lepisosteus platyrhincus) as 10 and $11 \%$, respectively (Williams and Trexler 2006). However, one suspected main prey source for alligators in the freshwater Everglades, the Seminole ramshorn snail (Planorbella duryi), in the same study had a mean $\delta^{15} \mathrm{~N}$ value of $5 \%$ (Barr 1997; Williams and Trexler 2006). A strong approach for future work would be to couple movement data with physiological bio-loggers and high-resolution diet tools like fatty acid bio-markers to validate the assumption that canals and alligator holes are primary foraging habitats and that alligators feed year-round.

For their home range, animals selected canal habitats in both seasons. It is thought that alligators, particularly males, prefer open water habitats because of the availability of larger prey items, unobstructed courtship areas, and thermal refuges (Joanen and McNease 1972). Other large-bodied wetland predators, such as piscivorous fish, use canals and alligator ponds disproportionate to their availability even during high water and in long hydroperiod sites indicating that these habitats may confer some advantage in prey interactions, ease of movement, or thermal properties over marsh habitats (Ontkos 2018; Parkos et al. 2015; Savino and Stein 1982; Turesson and Bronmark 2007). Like many other crocodilians, alligators are hypothesized to be opportunistic, nocturnal predators that primarily use sit and wait hunting tactics (Delany and Abercrombie 1986; Wolfe et al. 1987; Nifong et al. 2014). Thus, the most efficient movement tactic may be to remain near an alligator pond or canal where prey availability remains high compared to the shallow marsh throughout the year, but especially in the dry season (DeAngelis et al. 1997; Rehage and Loftus 2007). Though alligators strongly selected canal habitats for 
their home range they avoided them at the patch level. One explanation for incongruent habitat selection is that alligators were using the canal habitats more frequently than observed but were underwater and avoided detection. Satellite transmission will not occur when the animal is submerged; thus, many relocations in habitats where alligators might be spending more time underwater like canals were likely missed. We suggest that future studies could employ other telemetry methods that can yield underwater relocation information such as acoustic- or radio-telemetry (e.g. Rosenblatt and Heithaus 2011; Strickland et al. 2016).

Ontogenetic niche shifts and sex-specific behaviors of alligators are welldocumented. Several studies show a potential for these differences to connect habitats across terrestrial and aquatic ecosystems through the movement of energy and nutrients (Subalusky et al. 2009; Rosenblatt and Heithaus 2011). For instance, female and subadult alligators make many movements between seasonal wetlands, riverine systems, and forests primarily related to mating, nesting, and dispersal whereas adult males stayed exclusively in the riverine and creek habitats (Subalusky et al. 2009). In our study, male alligators had home ranges more than twice the size and had three times higher movement activity than females. Male alligators generally move more often and across greater distances than females (Joanen and McNease 1970, 1972; Goodwin and Marion 1979). However, specific reasons for differences in movements by sex are unclear. We speculate that some differences can be attributed to the larger body size of males which correlates with increased range size and activity. Male alligators in our study were longer in total length than the females, which is not surprising given that male crocodilians grow to larger sizes than females (McIhheny 1935; Platt et al. 2011; Woodward et al 1995). It 
is hypothesized that the body-size dimorphism is driven by the advantages larger males have in mating and resource defense where at sexual maturity female growth slows to shift energy towards reproduction (Platt et al. 2011). Large males are also thought to be the most dominant within social dominance hierarchies and may control access to resources and defend larger areas (Lang 1987). However, we did not observe differences in mean habitat use between males and females or differences in isotope values. Though it is important to note that high variability in $\delta^{15} \mathrm{~N}$ discrimination values for alligators, and possibility other large ectothermic tetrapods, in experimental settings reveal the complexity of assigning trophic levels in field studies (Rosenblatt and Heithaus 2013).

Many animals change activity and space use at the onset of the breeding period to increase encounter rates with potential mates (e.g., cottontail rabbits (Sylvilagus floridanus), Trent and Rongstad 1974; saltwater crocodiles, (Crocodylus porosus), Kay 2004). Some animals go to risky and energy-intensive lengths to maximize the opportunity to mate. For instance, male bank voles (Myodes glareolus) move long distances (over $1 \mathrm{~km}$ ) to search for breeding partners despite having home ranges only from 25 to $100 \mathrm{~m}$ wide (Kozakiewicz et al. 2007). We found that individual alligators used more space and, as a population, movement activity was over 2.5 times higher during the breeding period than during the non-breeding season. In fact, males and females had similar range sizes in the breeding period. Open water habitats such as canals and alligator ponds are relatively patchy throughout the study area and comprise a very small percentage of available habitat. However, canals were the most selected cover type in the home range at the population level and for every individual throughout the year. Alligators need open water for courtship, mating, displays of dominance, and other social 
interactions (Lang 1987; Joanen and McNease 1972). Animals, to access multiple mates in a single breeding period, may travel from patch to patch which may increase range size compared to the non-breeding period. For instance, in coastal marshes, male alligators seek canal habitats over marsh habitats and travel large distances to reach them (Joanen and McNease 1972). Female alligators are generally sedentary and remain near their nesting and denning locations outside of the breeding period (Joanen and McNease 1970; Goodwin and Marion 1979). While males remain in deep open water habitats year-round, breeding female alligators move to these areas to seek males for courtship (Mazzotti and Brandt 1994). For instance, in an inland Florida lake, female alligators used flooded swamp habitats during most of the year but moved into deeper, open water lake habitats during the courtship period (Goodwin and Marion 1979). Unfortunately, we were not able to determine which females were breeding or nesting during the tracking period. In a Louisiana freshwater marsh, female alligators had larger ranges and movement rates during spring and courtship than other periods (Rootes and Chabreck 1993). These patterns were for all females and Rootes and Chabreck (1993) reported no differences between movement rates and range sizes of nesting and non-nesting females and those with and without broods.

Larger animals are expected to require larger home range sizes because of increased metabolic demands (Said and Servanty 2005; Ofstad et al. 2016). In our study, larger animals had larger home ranges. However, increased energetic requirements alone may not fully characterize the size relationship in alligators. There is evidence that body size can predict range size for mammals particularly ungulates, but other factors like landscape characteristics are important determinants as well (Lindstedt et al. 1986; Ofstad 
et al. 2016; Jetz et al. 2004). For instance, across multiple ungulate species in different environments, open habitats led to larger home ranges and weaker allometric relationships compared to more closed habitats after adjusting for body size (Ofstad et al. 2016). Densely-vegetated habitats like freshwater marshes which are interspersed with patchy high-quality areas of open water may complicate the relationship of body size to range size for our population of alligators. A meta-analysis of the effects of different habitats, body size, or sex on crocodilian movements and range sizes has not been undertaken (but see Tamburello et al. 2015). Studies of crocodilians show that social status can be largely explained by body size with large males generally controlling access to both mates and food (Lang 1987; Johnson 1973; Strickland et al. 2016). Size-based dominance hierarchies facilitate larger animals to have the ability to access more suitable habitats containing higher quality resources. In some cases, despots can obtain resources in a smaller area, but in other situations subordinates may be relegated to a smaller area and despots may have access to more spread-out patches across the landscape. Indeed, we found that larger animals had higher movement activity than smaller individuals. It is important to note that the effect of hierarchies on individual movements, resource use, and home range size may interact with population density and habitat structure (Jetz et al. 2004; Strickland et al. 2016). We did not find that animal core use area size varied with body size. Only two of the 14 animals had a core use area smaller than our maximum estimated location error. At small scales, as measured by the core use area size, adult alligators regardless of body size might have a minimum amount of space needed for basic sedentary life functions such as thermoregulation behaviors and resting which dominate their activity as ectothermic poikilotherms. Alligator movement activity was 
positively correlated with average daily temperature, but it appears to exhibit a bell-shape relationship where below $\sim 20^{\circ} \mathrm{C}$ and above $\sim 30^{\circ} \mathrm{C}$ alligator activity was the lowest. Thermoregulation likely becomes more complicated at low and high temperatures with alligators using heat-seeking (e.g., basking) and heat-avoiding (e.g., underwater buffering) behaviors, which are relatively sedentary and may limit satellite transmissions (Lang 1987; Bugbee 2008).

Body condition is a widely-used indicator of animal health and environmental stress and may be related to fitness (Baines et al. 2015; Jakob et al. 1996). However, the relationship of body condition to movement behavior and dispersal is complex (Baines et al. 2015). We predicted that poor body condition individuals will have high movement activity and large ranges to access resources whereas animals in good condition might have small ranges. Indeed, poor body condition animals had large home ranges, particularly in the wet season, and high movement activity rates compared to good condition animals. Everglades alligators are in generally poor condition relative to animals across the rest of their range (Brandt et al. 2016; Dalrymple 1996; Fujisaki et al. 2009). Relatively poor condition is thought to be related to the harsh environmental conditions experienced in the Everglades (e.g., high temperatures and drastic changes in water levels) (Brandt et al. 2016; Dalrymple 1996; Fujisaki et al. 2009). Our tracked animals with poor body condition may have spent more energy searching for patches with high returns, particularly in the wet season when food distribution is not concentrated and capture efficiencies likely decrease compared to the dry season. However, body condition is plastic and likely changed after its measure at capture and over the tracking period. Thus, along with our relatively small sample size and limited 
range of body conditions, future studies targeting the body condition and movement relationship could potentially use recaptures to provide insight into the consequences of remaining in low-condition states in a dynamic wetland.

It is generally thought that alligators forage at night and some populations are potentially more active at night than during the day (Rosenblatt et al. 2013) though others show high daytime activity (Wantanabe et al. 2013; Nifong et al. 2014). Nearly all of our most accurate class locations were transmitted at night. Submergence rates for alligators are thought to be highest during the day, which would limit air exposure for satellite transmissions when animals are underwater (Wantanabe et al. 2013; Bugbee 2008). Alligators also actively seek deep water or floating vegetation to buffer extreme heat rather than spending time on land during hot days (Bugbee 2008; Strickland et al. 2016). It is surprising that we did not detect animals regularly during daytime basking especially given that Argos telemetry performance is thought to be relatively robust to variables such as vegetation and canopy coverage (Sauder et al. 2012). However, fouling of the metal wet/dry sensors can reduce uplink rates (Sauder et al. 2012) and a transmitter's antenna has to completely break the surface of the water long enough to transmit a signal (Dwyer et al. 2015). Regardless, there is no reason to believe that anything other than animal behavior led to differences in the number of day and night relocations.

There is increasing recognition of the importance of considering scale in the understanding of ecological patterns and processes. We found that alligators did not have congruency in selection of habitats at different spatial scales. Habitat selection is expected to be a hierarchical process where animals select or avoid certain habitats at different spatial scales. For instance, alligators strongly selected canal habitats at the 
home range level but avoided canals at the patch level and instead chose strongly selected patches of sawgrass marsh. We also did not find a relationship between animal activity within different habitat cover types. Thus, movement behavior was relatively consistent within the broad habitat categories we classified. Beyond associations with specific habitats, the relationship of crocodilian behavior and activity to many environmental variables is complex. We did not observe any relationship between movement activity and rainfall or fraction of the moon illuminated. It is thought that alligator foraging efficiency may increase with moon illumination as a consequence of increased activity by many prey species (Eversole et al. 2015). Thus, during times of high illumination alligators may be more active but may spend more time underwater and out of range of satellites for transmissions. Several studies show that crocodilians seek shelter underwater from high rain and both turbidity and wave action from rainfall are thought to limit foraging activity (Murphy 1977; Bugbee 2008; Strickland et al. 2018). However, high rainfall, particularly storms with high wind and hydrological changes, may force some animals to be displaced and or move to seek shelter (Strickland et al. 2020).

Ecological effects of restoration and regional hydrology management tools such as water releases and are not always well-studied and are likely context-dependent. Despite on-going major restoration efforts, the Florida Everglades still remains an intensively hydrologically managed system (Sklar et al. 2005). Our findings show that alligator movement behaviors are affected by seasonal and anthropogenic changes in hydrology. In addition, movement responses of alligators are driven by sex-specific differences, breeding activity, body size, and body condition. Empirical information about drivers and scales of movement behavior, particularly for ecologically important 
large-bodied mobile predators, will help us predict community and ecosystem responses to environmental change and restoration. However, given the complexity of drivers and the diversity of patterns of movement behaviors observed, we suggest future studies that combine movement and biologging technologies with large numbers of individuals.

Alligators are indicators for restoration of Everglades ecosystems because of their important roles as predators and ecosystem engineers (Mazzotti et al. 2009).

Understanding sources of variation and identifying the relevant temporal and spatial scale of movements for alligators will allow for a thorough assessment of their ecological importance. For instance, large-bodied organisms may have increased potential to generate landscape-level nutrient heterogeneity from excretion as a result of their capacity for long-distance movements and consumption of considerable biomass. Hotspots may exist where the magnitude of nutrient fluxes are particularly high compared to the surrounding matrix (McClain et al. 2003) and resting areas of large-bodied organisms may be related to increased nutrient release from biodeposition. The implications of a sedentary large-bodied ectothermic apex predator in an oligotrophic zone, such as the Everglades freshwater marsh, could be that local nutrient hotspots are created from excretion patterns (assuming animals excrete primarily in their "resting" core use areas). Another effect could be concentrated bioturbation from large-bodied animals moving in a relatively small area.

\section{Acknowledgements}

This work was supported by the National Science Foundation through the Florida Coastal Everglades Long-Term Ecological Research program under Grant \#DEB- 
1237517 and DEB-1832229. We are grateful to many field and lab volunteers that assisted with capture and sample processing. Frank Mazzotti, Jeff Beauchamp, Kirk Gastrich, and Mike Heithaus were critical to the project and chapter. Adam Rosenblatt's pioneering work directed the line of investigation for this project. Joel Trexler's enthusiasm and input into the work was tremendously valuable. Mo van Zinnicq Bergmann provided draft R code that was helpful for the analysis. Katherine Strickland provided graphic design assistance. This is a contribution from the Center for Coastal Oceans Research in the Institute for Water and Environment at Florida International University. BAS was supported by the University Graduate School and Department of Biological Sciences assistantships at Florida International University as well as an Everglades Foundation fellowship. Research and animal procedures were conducted under the auspices of protocol \#IACUC-15-044-CR01 from the Institutional Animal Care and Use Committee of the University of Florida and in accordance with sampling permits \#EVER-2013-SCI-0020 and \#EVER-2015-SCI-0036 granted by Everglades National Park.

\section{Literature Cited}

Armitage, A.R., S.M. Jensen, J.E. Yoon, and R.F. Ambrose. 2007. Wintering shorebird assemblages and behavior in restored tidal wetlands in southern California. Restoration Ecology 15(1):139-148.

Atkinson, C.L., K.A. Capps, A.T. Rugenski, and M.J. Vanni. 2017. Consumer-driven nutrient dynamics in freshwater ecosystems: from individuals to ecosystems. Biological Reviews 92:2003-2023.

Baines CB, McCauley SJ, Rowe L. 2015. Dispersal depends on body condition and predation risk in the semi-aquatic insect, Notonecta undulata. Ecology and Evolution 5(12): 2307-2316. 
Barr, B. 1997. Food habits of the American alligator, Alligator mississippiensis, in the southern Everglades. University of Miami, Dissertation. 259 pp.

Beerens, J.M., J.C. Trexler, and C.P. Catano. 2017. Predicting wading bird and aquatic faunal responses to ecosystem restoration scenarios. Restoration Ecology 25(51):S86-S98.

Bivand, R. and N. Lewin-Koh. 2019. Maptools: tools for handling spatial objects. R package version 0.9-5. https://CRAN.R-project.org/package=maptools.

Brandt, L.A., J.S. Beauchamp, B.M. Jeffery, M.S. Cherkiss, and F.J. Mazzotti. 2016. Fluctuating water depths affect American alligator (Alligator mississippiensis) body condition in the Everglades, Florida, USA. Ecological Indicators 67:441450.

Brien, M., G. Webb, C. Manolis, G. Lindner, and D. Ottoway. 2010. A method for attaching tracking devices to crocodilians. Herpetological Review 41:305-308.

Bruland, G.L., S. Grunwalk, T.Z. Osborne, K.R. Reddy, and S. Newman. 2006. Spatial distribution of soil properties in Water Conservation Area 3 of the Everglades. Soil Science Society of America Journal 70:1662-1676.

Brusati, E.D., P.J. DuBowy, and T.E. Lacher. 2001. Comparing ecological functions of natural and created wetlands for shorebirds in Texas. Waterbirds 24:371-380.

Bugbee, C.D. 2008. Emergence dynamics of American Alligators in Arthur R. Marshall Loxahatchee National Wildlife Refuge: life history and application to statewide alligator surveys. M.Sc. Thesis, University of Florida, Gainesville, Florida, USA. $115 \mathrm{p}$.

Byrne, M.E., J.C. McCoy, J.W. Hinton, M.J. Chamberlain, and B.A. Collier. 2014. Using dynamic Brownian brige movement modelling to measure temporal patterns of habitat selection. Journal of Animal Ecology 83:1234-1243.

Chabreck, R. H. 1963. Methods of capturing, marking, and sexing alligators. Proceedings of the Southeastern Association of Game and Fish Commissioners 17:47-50.

Chabreck, R. H. 1965. The movement of alligators in Louisiana. Proceedings of the Southeastern Association of Game and Fish Commissioners 19:102-110.

Chester, E.T., and B.J. Robson. 2011. Drought refuges, spatial scale and recolonisation by invertebrates in non-perennial streams. Freshwater Biology 56(10):2094-2104. 
Chick, J. H., C. R. Ruetz, III, and J. C. Trexler. 2004. Spatial scale and abundance patterns of large fish communities in freshwater marshes of the Florida Everglades. Wetlands 24:652-664.

Dalrymple, G. H. 1996. Growth of American alligators in the Shark Valley region of Everglades National Park. Copeia 1996:212-216.

DeAngelis, D.L., W.F. Loftus, J.C. Trexler, and R.E. Ulanowicz. 1997. Modeling fish dynamics and effects of stress in a hydrologically pulsed ecosystem. Journal of Aquatic Ecosystem Stress and Recovery 6:1-13.

Delany, M.F. and C. Abercrombie. 1986. American alligator food habits in northcentral Florida. Journal of Wildlife Management 50:348-353.

Dorn, N.J., J.C. Trexler, and E.E. Gaiser. 2006. Exploring the role of large predators in marsh food webs: evidence for a behaviorally-mediated trophic cascade. Hydrobiologia 569:375-386.

Duever, M. J., J. F. Meeder, L. C. Meeder, and J. M. McCollom. 1994. The climate of South Florida and its role in shaping the Everglades ecosystem, p. 225-248. In: Everglades: The Ecosystem and Its Restoration. S. M. Davis and J. C. Ogden (eds.). St. Lucie Press, Boca Raton, Florida.

Dwyer, R.G., H.A. Campbell, T. Irwin, and C.E. Franklin. 2015. Does the telemetry technology matter? Comparing estimates of aquatic animal space-use generated from GPS-based and passive acoustic tracking. Marine and Freshwater Research 66(7): 654-664.

Erwin, K.L. 2009. Wetlands and global climate change: the role of wetland restoration in a changing world. Wetlands Ecology and Management 17:71.

Estes, J.A., M. Heithaus, D.J. McCauley, D.B. Rasher, and B. Worm. 2016. Megafaunal impacts on structure and function of ocean ecosystems. Annual Review of Environment and Resources 41:83-116.

Eversole, C.B., S.E. Henke, D.B. Wester, B.M. Ballard, and R.L. Powell. 2015. Responses of American Alligators to environmental conditions: implications for population and ecosystem monitoring. Herpetologica 71:37-45.

Fieberg, J. and C.O. Kochanny. 2005. Quantifying home-range overlap: the importance of the utilization distribution. Journal of Wildlife Management 69(4):1346-1359.

Fujisaki, I., K.G. Rice, L.G. Pearlstine, and F.J. Mazzotti. 2009. Relationship between body condition of American alligators and water depth in the Everglades, Florida. Hydrobiologia 635:329-338. 
Fujisaki, I., F.J. Mazzotti, R.M. Dorazio, K.G. Rice, M. Cherkiss, and B. Jeffery. 2011. Estimating trends in alligator populations from nightlight survey data. Wetlands 31:147-155.

Fujisaki, I., K. M. Hart, F. J. Mazzotti, M. S. Cherkiss, A. R. Sartain, B. M. Jeffery, J. S. Beauchamp, and M. Denton. 2014. Home range and movements of American alligators (Alligator mississippiensis) in an estuary habitat. Animal Biotelemetry $2: 1-10$.

Fujisaki, I., K. M. Hart, M. S. Cherkiss, F. J. Mazzotti, J. S. Beauchamp, B. M. Jeffery, and L. A. Brandt. 2016. Spatial and temporal variability in estuary habitat use by American alligators. Estuaries and Coasts 39:1561-1569.

Gawlik, D.E. 2006. The role of wildlife science in wetland ecosystem restoration: lessons from the Everglades. Ecological Engineering 26: 70-83.

Goodwin, T. M., and W. R. Marion. 1979. Seasonal activity ranges and habitat preferences of adult alligators in a north-central Florida lake. Journal of Herpetology 13:157-164.

Goss, W.G., W.F. Loftus, and J.C. Trexler. 2014. Seasonal fish dispersal in ephemeral wetlands of the Florida Everglades. Wetlands 34:S147-S157.

Jakob, E.M., S.D. Marshall and G.W. Uetz. 1996. Estimating fitness: a comparison of body condition indices. Oikos 77: 61-67.

Jetz W, Carbone C, Fulford J, Brown JH. 2004 The scaling of animal space use. Science 306, 266 - 268. (doi:10.1126/science.1102138).

Joanen, T., and L. McNease. 1970. A telemetric study of nesting female alligators on Rockefeller Refuge, Louisiana. Proceedings of the Southeastern Association of Game and Fish Commissioners 20:175-193.

Joanen, T., and L. McNease. 1972. A telemetric study of adult male alligators on Rockefeller Refuge, Louisiana. Proceedings of the Southeastern Association of Game and Fish Commissioners 26:252-275.

Johnson, C.R. 1973. Behaviour of the Australian crocodiles, Crocodylus johnstoni and C. porosus. Zoological Journal of Linneus Society 52: 315-336.

Jordan, F., H. L. Jelks, and W. M. Kitchens. 1997. Habitat structure and plant community composition in a northern Everglades wetland communitiy. Wetlands. Volume 17.

Julian, P. 2013. Mercury hotspot identification in Water Conservation Area 3, Florida, USA. Annals of GIS 19(2):79-88. 
Kay, W. R. 2004. Movements and home ranges of radio-tracked Crocodylus porosus in the Cambridge Gulf region of Western Australia. Wildlife Research 31:495-508.

Kie, J.G., J. Matthiopoulos, J. Fieberg, R.A. Powell, F. Cagnacci, M.S. Mitchell, J. Gaillard, and P.R. Moorcroft. 2010. The home range concept: are traditional estimators still relevant with modern telemetry technology? Phil. Trans. R. Soc. B. 365: 2221-2231.

Kozakiewicz, M., A. Choluj, and A. Kozakiewicz. 2007. Long distance movements of individuals in a free-living bank vole population: an important element of male breeding strategy. Acta Theriologica 52:339-348.

Kranstauber, B., R. Kays, S. D. Lapoint, M. Wikelski, and K. Safi. 2012. A dynamic Brownian bridge movement model to estimate utilization distributions for heterogeneous animal movement. Journal of Animal Ecology 81:738-746.

Kranstauber, B., M. Smolla, and A.K. Scharf. 2019. Move: visualizing and analyzing animal track data. $\mathrm{R}$ package version 3.2.2. https://CRAN.Rproject.org/package $=$ move.

Kushlan, J. A. 1974. Observations on the role of the American alligator in the Southern Flordia wetlands. Copeia 4:993-996.

Lance, V.A. 2003. Alligator physiology and life history: the importance of temperature. Experimental Gerontology 38(7):801-805.

Lang, J. W. 1987. Crocodilian behaviour: implications for management. Pages 273-293 in G. Webb, S. C. Manolis, and P. J. Whitehead, editors. Wildlife management: crocodiles and alligators. Surrey Beatty \& Sons, Sydney, Australia.

Lindell, C.A. 2008. The value of animal behavior in evaluations of restoration success. Restoration Ecology 16(2):197-203.

Lindstedt SL, Miller BJ, Buskirk SW. 1986 Home range, time, and body size in mammals. Ecology 67, 413 - 418. (doi:10.2307/1938584)

Manly B.F.J., McDonald L.L., Thomas, D.L., McDonald, T.L. \& Erickson, W.P. 2002. Resource selection by animals - Statistical design and Analysis for field studies. Second edition London: Kluwer academic publishers.

Mazzotti, F. J., and L. A. Brandt. 1994. Ecology of the American alligator in a seasonally flucutating environment. S. M. Davis and W. A. Park, editors. Everglades: The Ecosystem and Its Restoration. St. Lucie Press. 
Mazzotti, F.J., F.R. Best, L.A. Brandt, M.S. Cherkiss, B.M. Jeffery, and K.G. Rice. 2009. Alligators and crocodiles as indicators for restoration of Everglades ecosystems. Ecological Indicators 9(6):S137-S149.

McClain, M. E., E. W. Boyer, C. L. Dent, S. E. Gergel, N. B. Grimm, P. M. Groffman, S. C. Hart, J. W. Harvey, C. A. Johnston, E. Mayorga, W. H. McDowell, and G. Pinay. 2003. Biogeochemical hot spots and hot moments at the interface of terrestrial and aquatic ecosystems. Ecosystems 6:301-312.

McIlhenny, E.A. 1935. The alligator's life history. Boston, Massachusetts: Christopher Publishing House.

McNease, L., and T. Joanen. 1974. A study of immature alligators on Rockefeller Refuge, Louisiana. Proceedings of the Southeastern Association of Game and Fish Commissioners 28:482-500.

Mitsch, W.J. and J.G. Gosselink. 2015. Wetlands. $5^{\text {th }}$ edition. John Wiley \& Sons, Hoboken, New Jersey.

Murphy, T. M. 1977. Distribution, movement, and population dynamics of the American alligator in a thermally altered reservoir. University of Georgia.

National Academies of Sciences, Engineering, and Medicine (NASEM). 2016. Progress Toward Restoring the Everglades: The Sixth Biennial Review - 2016. Washington, DC: The National Academies Press. Doi: 10.17226/23672.

National Oceanic and Atmospheric Administration (NOAA). 2019. National Centers for Environmental Information. https://www.ncei.noaa.gov/. Accessed 20 July 2019.

Nifong, J. C., and B. R. Silliman. 2013. Impacts of a large-bodied, apex predator (Alligator mississippiensis Daudin 1801) on salt marsh food webs. Journal of Experimental Marine Biology and Ecology 440:185-191.

Nifong, J.C., R.L. Nifong, B.R. Silliman, R.H. Lowers, L.J. Guillette Jr., J.M. Ferguson, M. Welsh, K. Aberbathy, and G. Marshall. 2014. Animal-borne imaging reveals novel insights into the foraging behaviors and diel activity of a large-bodied apex predator, the American alligator. PLoS ONE 9(1):e83953.

Ofstad EG, Herfindal I, Solberg EJ, Sæther B-E. 2016 Home ranges, habitat and body mass: simple correlates of home range size in ungulates. Proc. R. Soc. B283: 20161234.

Ontkos, A.T. 2018. Habitat use of three abundant predatory fish species in the freshwater Everglades. Florida International University, Master's Thesis. 66 pp. 
Parkos, J.J., C.R. Ruetz, and J.C. Trexler. 2011. Disturbance regime and limits on benefits of refuge use for fishes in a fluctuating hydroscape. Oikos 120:15191530 .

Parkos, J.J., L.F. Wolski, W.F. Loftus, and J.C. Trexler. 2015. Dynamic movement patterns of Florida gar within a fluctuating hydroscape. Copeia 103(1):132-140.

Platt SG, Rainwater TR, Thorbjanarson JB, Finger AG, Anderson TA, and McMurry ST. 2011. Size estimation, morphometrics, sex ratio, sexual size dimorphism, and biomass of Crocodylus acutus in the coastal zone of Belize. Salamandra 47:179192.

Rehage, J.S., and J.C. Trexler. 2006. Assessing the net effect of anthropogenic disturbance on aquatic communities in wetlands: community structure relative to distance from canals. Hydrobiologia 569:359-373.

Rehage, J.S., and W.F. Loftus. 2007. Seasonal fish community variation in headwater mangrove creeks in the southwestern Everglades: an examination of their role as dry-down refuges. Bulletin of Marine Science 80:625-645.

Rootes, W.L. and R.H. Chabreck. 1993. Reproductive status and movement of adult female alligators. Journal of Herpetology 27: 121-126.

Rosenblatt, A. E., and M. R. Heithaus. 2011. Does variation in movement tactics and trophic interactions among American alligators create habitat linkages? The Journal of Animal Ecology 80:786-798.

Rosenblatt, A. and M.R. Heithaus. 2013. Slow isotope turnover rates and low discrimination values in the American alligator: implications for interpretation of ectotherm stable isotope data. Physiol Bio- chem Zool 86:137-148.

Rosenblatt, A. E., M. R. Heithaus, F. J. Mazzotti, M. Cherkiss, and B. M. Jeffery. 2013. Intra-population variation in activity ranges, diel patterns, movement rates, and habitat use of American alligators in a subtropical estuary. Estuarine, Coastal and Shelf Science 135:182-190.

Rosenblatt, A.E., J.C. Nifong, M.R. Heithaus, F.J. Mazzotti, M.S. Cherkiss, B.M. Jeffery, R.M. Elsey, R.A. Decker, B.R. Silliman, L.J. Guillette, R.H. Lowers, J.C. Larson. 2015. Factors affecting individual foraging specialization and diet stability across the range of a large "generalist" apex predator. Oecologia 178:5-16.

Said, S. and S. Servanty. 2005. The influence of landscape structure on female roe deer home-range size. Landscape Ecology 20: 1003-1012. 
Sauder, J.D., J.L. Rachlow, and M.W. Wiest. 2012. Influence of topography and canopy cover on Argos satellite telemetry performance. Wildlife Society Bulletin 36(4): 813-819.

Savino, J.F. and R.A. Stein. 1982. Predator-prey interaction between largemouth bass and bluegills as influenced by simulated, submersed vegetation. Transactions of the American Fisheries Society 111:255-266.

Sklar, F.H., Chimney, M.J., Newman, S., McCormick, P., Gaw- lik, D., Miao, S., McVoy, C., Said, W., Newman, J., Coro- nado, C., Crozier, G., Korvela, M., Rutchey, K., 2005. The ecological-societal underpinnings of Everglades restoration. Front. Ecol. Environ. 3, 161-169.

South Florida Water Management District. 2019. 2014-2016 Land cover land use database. https://geo-sfwmd.hub.arcgis.com/datasets/sfwmd-land-cover-land-use2014-2016. Accessed 30 October 2019.

Strickland, B. A., F. J. Vilella, and J. L. Belant. 2016. Scale-dependent habitat selection and size-based dominance in adult male American alligators. PLoS ONE 11:1-16.

Strickland, B.A., F.J. Vilella, and R.D. Flynt. 2018. Long-term spotlight surveys of American alligators in Mississippi, USA. Herpetological Conservation and Biology 13(2):331-340.

Strickland, B.A., K. Gastrich, F.J. Mazzotti, J.A. Massie, V. Paz, N. Viadero, J.S. Rehage, and M.R. Heithaus. 2020. Variation in movement behavior of alligators after a major hurricane. Animal Biotelemetry, 8(1), 1-10.

Subalusky, A. L., L. A. Fitzgerald, and L. L. Smith. 2009. Ontogenetic niche shifts in the American alligator establish functional connectivity between aquatic systems. Biological Conservation 142:1507-1514.

Tamburello N, Cote IM, Dulvy NK. 2015 Energy and the scaling of animal space use. Am. Nat. 186, 196 - 211. (doi:10.1086/682070)

Thieurnmel, B. and A. Elmarchraoui. 2019. suncalc: compute sun position, sunlight phases, moon position, and lunar phase. R package version 0.5.0. https://CRAN.R-project.org/package $=$ suncalc.

Thomas D. L. and Taylor E. J. 1990. Study designs and tests for comparing resource use and availability. Journal of Wildlife Management 54:322-330.

Trent, T.T. and O.J. Rongstad. 1974. Home range and survival of cottontail rabbits in southwestern Wisconsin. The Journal of Wildlife Management 38(3):459-472. 
Trexler, J. C., W. F. Loftus, F. Jordan, J. H. Chick, K. H. Kandl, T. C. McElroy, and O. L. Bass, Jr. 2002. Ecological scale and its implications for freshwater fishes in the Florida Everglades, p. 153-181. In: The Everglades, Florida Bay, and Coral Reefs of the Florida Keys: An Ecosystem Source Book. J. W. Porter and K. G. Porter (eds.). CRC Press, Boca Raton, Florida.

Trexler, J.C., W.F. Loftus, and S. Perry. 2005. Disturbance frequency and community structure in a twenty-five year intervention study. Oecologia 145:140-152.

Turesson, H. and C. Brönmark. 2007. Predator-prey encounter rates in freshwater piscivores: effects of prey density and water transparency. Oecologia 153:281290.

Watanabe, Y. Y., E. A. Reyier, R. H. Lowers, J. L. Imhoff, and Y. P. Papastamatiou. 2013. Behavior of American alligators monitored by multi-sensor data loggers. Aquatic Biology 18:1-8.

Webb, K.K., A.F. Zuur, G.E. Calkins, and J.P. Duguay. 2009. Habitat use of American Alligators in east Texas. Journal of Wildlife Management 73:566-572.

Williams, A.J. and J.C. Trexler. 2006. A preliminary analysis of the correlation of foodweb characteristics with hydrology and nutrient gradients in the southern Everglades. Hydrobiologia 569:493-504.

Wolfe, J., D.K. Bradshaw, and R.H. Chabreck. 1987. Alligator feeding habitats: new data and a review. Northeast Gulf Science 9:1-8.

Woodward, A.R., J.H. White, and S.B. Linda. 1995. Maximum size of the alligator (Alligator mississippiensis). Journal of Herpetology 29(4): 507-513.

United States Geological Survey (USGS). 2019. Everglades Depth Estimation Network database. https://sofia.usgs.gov/eden/. Accessed 26 September 2019.

Van der Merwe, J., E.C. Hellgren, and E.M. Schauber. 2016. Variation in metapopulation dynamics of a wetland mammal: the effect of hydrology. Ecosphere 7(3):e01275.

Zedler, J.B. 2000. Progress in wetland restoration ecology. Trends in Ecology and Evolution 15(10):402-407. 
Table 1: Median and range of home range and core use area size, defined by the area in $\mathrm{km}^{2}$ of the $95 \%$ and $50 \%$ utilization distributions, respectively, and mean and standard deviation (SD) of Brownian motion variance, an indicator of movement activity, across seasons and breeding period for American alligators (Alligator mississippiensis) in Water Conservation Area 3, Florida, USA tracked using satellite telemetry (2014-2015) for which there were sufficient relocations.

\begin{tabular}{|c|c|c|c|c|c|}
\hline \multirow[b]{2}{*}{ Timeframe } & \multirow[b]{2}{*}{$n$ (animals) } & \multirow{2}{*}{$\begin{array}{c}\text { Home Range } \\
\text { Median (range) } \\
\left(\mathrm{km}^{2}\right)\end{array}$} & \multirow{2}{*}{$\begin{array}{c}\text { Core Use Area } \\
\text { Median (range) } \\
\left(\mathrm{km}^{2}\right)\end{array}$} & \multicolumn{2}{|c|}{ Motion variance } \\
\hline & & & & $n$ (relocations) & Mean $\pm \mathrm{SD}$ \\
\hline Study period & 14 & $6.5(1.0,14.4)$ & $1.1(0.2,1.7)$ & 1,886 & $481 \pm 806$ \\
\hline Wet season & 10 & $6.9(3.0,17.2)$ & $1.1(0.4,1.7)$ & 1,211 & $559 \pm 843$ \\
\hline Dry season & 8 & $6.2(3.2,17.1)$ & $1.0(0.5,2.1)$ & 675 & $339 \pm 712$ \\
\hline Breeding period & 9 & $12.3(3.5,62.3)$ & $1.6(0.7,5.3)$ & 493 & $912 \pm 1226$ \\
\hline Non-breeding period & 9 & $6.1(2.6,8.0)$ & $1.0(0.4,1.6)$ & 1,393 & $336 \pm 529$ \\
\hline
\end{tabular}


Table 2: Percent composition of the study area, percent mean and standard deviation (SD) of home range, defined by the area of the $95 \%$ utilization distribution, and relocations, and mean and SD of Brownian motion variance, an indicator of movement activity, by habitat type for American alligators (Alligator mississippiensis) in Water Conservation Area 3, Florida, USA tracked using satellite telemetry (2014-2015) for which there were sufficient relocations.

\begin{tabular}{c|c|c|c|c}
\hline \multirow{2}{*}{ Habitat } & Study Area & Home Range & Relocations & Motion variance \\
\hline \% Composition & $\%$ Mean \pm SD & $\%$ Mean \pm SD & Mean \pm SD \\
\hline Sawgrass & 50.7 & $28.3 \pm 17.0$ & $59.8 \pm 31.2$ & $443 \pm 742$ \\
\hline Spikerush & 43.6 & $30.6 \pm 18.2$ & $33.2 \pm 30.2$ & $491 \pm 842$ \\
\hline Woody Vegetation & 3.5 & $21.0 \pm 10.8$ & $3.2 \pm 4.2$ & $703 \pm 1113$ \\
\hline $\begin{array}{c}\text { Mixed Emergent } \\
\text { Vegetation }\end{array}$ & 1.9 & $5.8 \pm 2.7$ & $3.4 \pm 5.8$ & $747 \pm 1010$ \\
\hline Canal & 0.3 & $14.3 \pm 8.3$ & $0.4 \pm 0.6$ & $941 \pm 1255$ \\
\hline
\end{tabular}


Figure 1: Map of Water Conservation Area 3, Florida, USA.

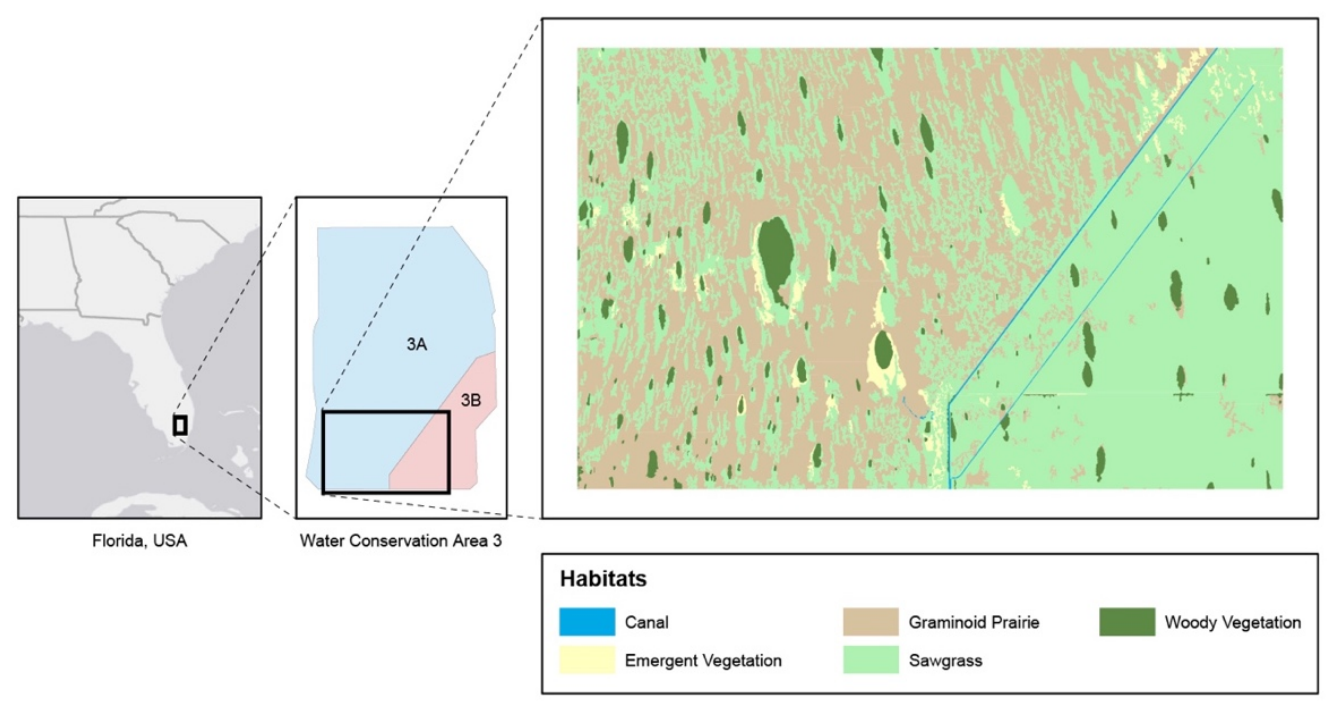


Figure 2: Home range size, defined by the area of the $95 \%$ utilization distribution, across the wet season, dry season, and breeding period for both male and female satellitetracked American alligators (Alligator mississippiensis) in Water Conservation Area 3, Florida, USA (2014-2015).

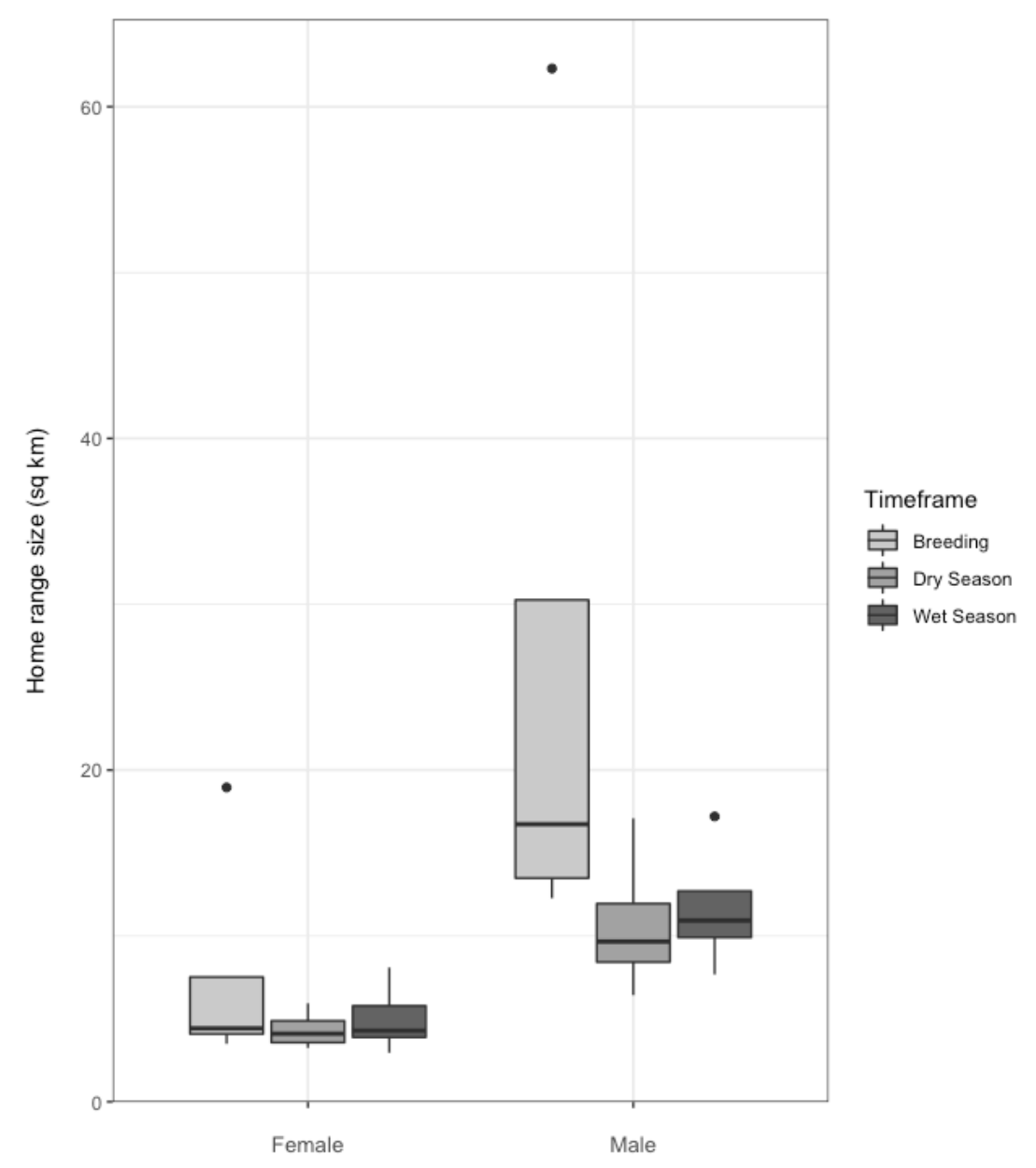


Figure 3: Home range size, defined by the area of the $95 \%$ utilization distribution, and mean movement activity (Brownian motion variance) compared across satellite-tracked American alligators (Alligator mississippiensis) of different total lengths and body conditions in Water Conservation Area 3, Florida, USA (2014-2015).
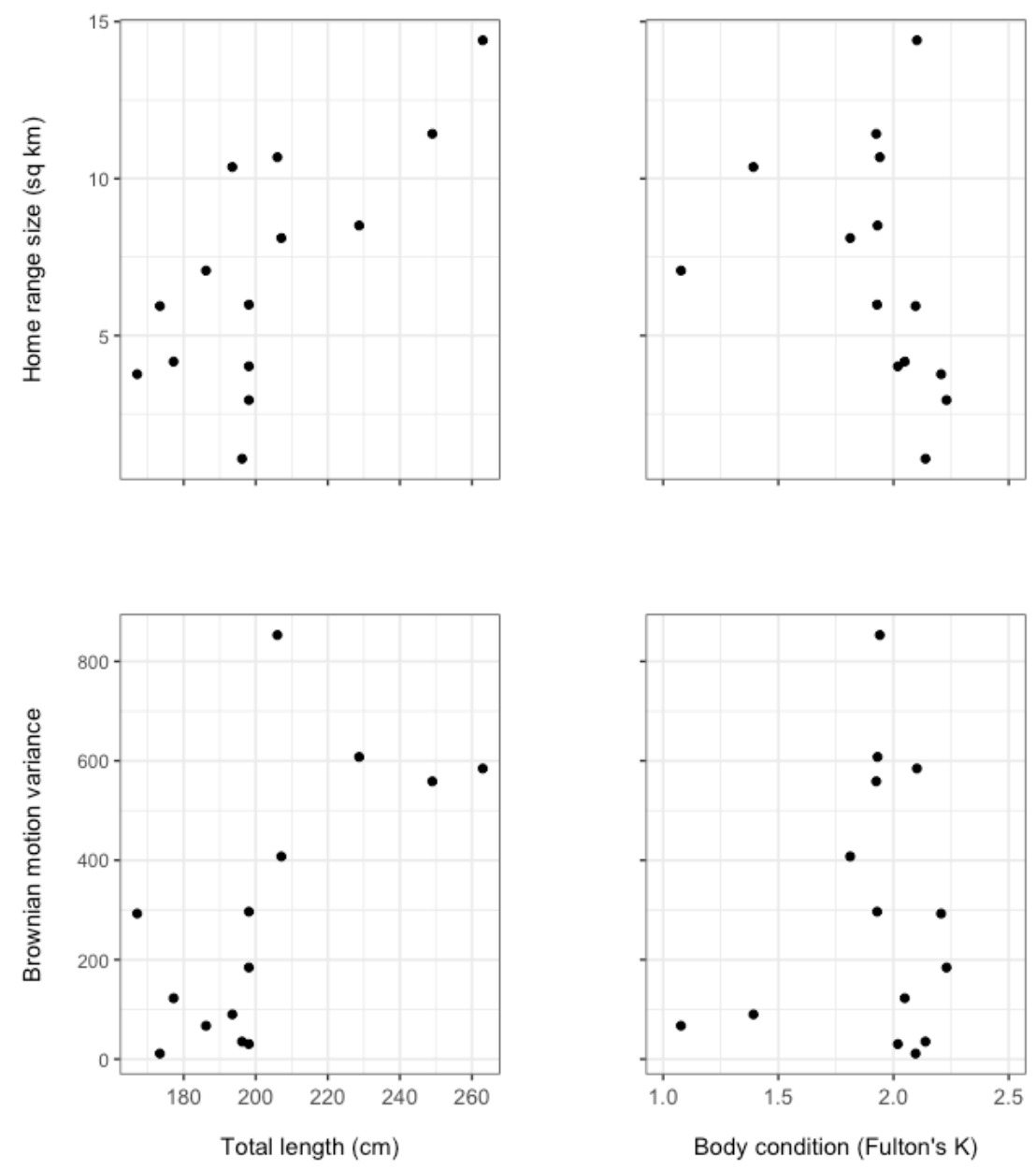
Figure 4: Movement activity (Brownian motion variance) of satellite-tracked American alligators (Alligator mississippiensis) in the 30-days before and the first 30-days during an experimental water release in Water Conservation Area 3, Florida, USA from 4 November 2014 to 29 January 2015.

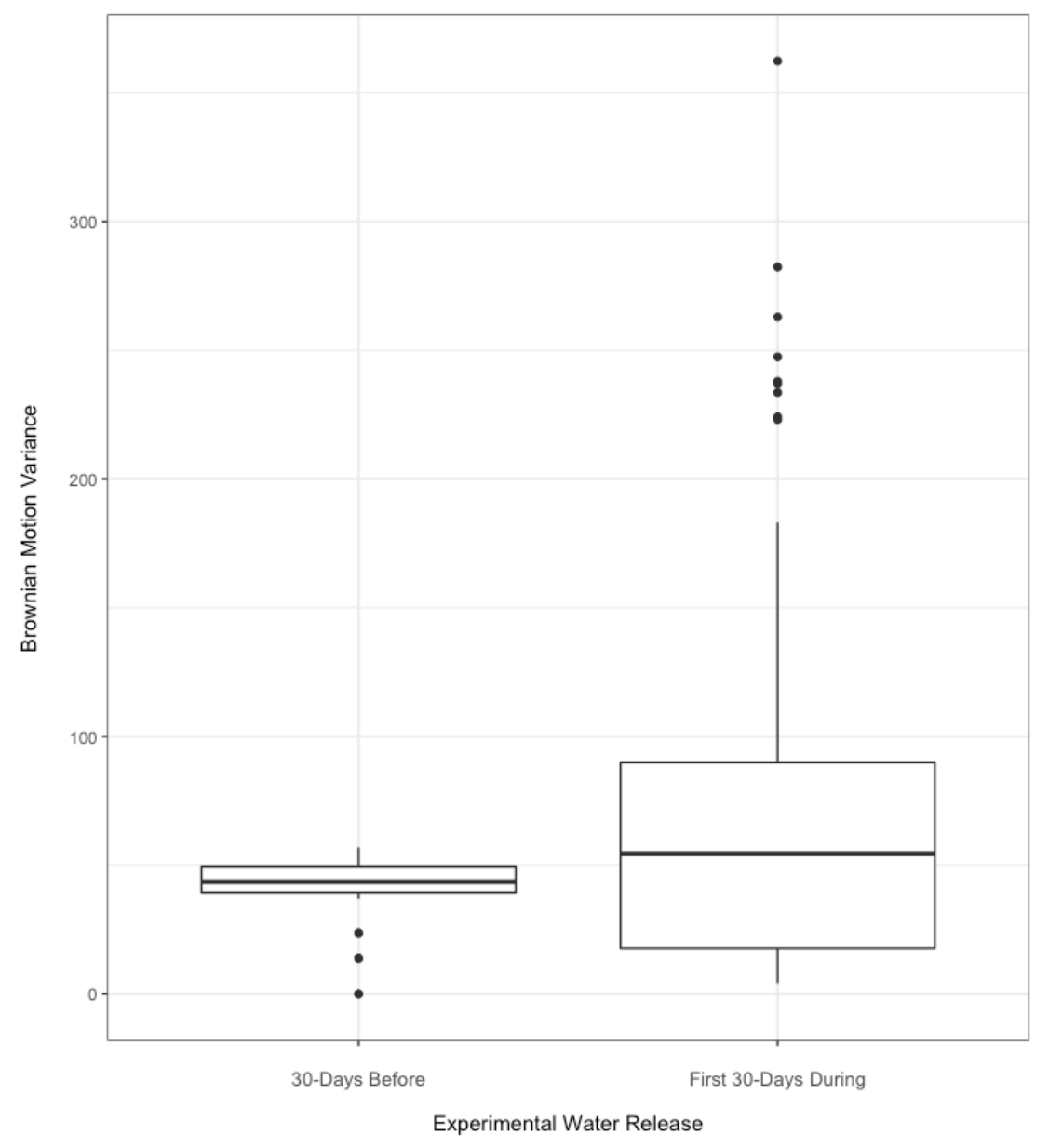


Figure 5: Movement activity (Brownian motion variance) of male ("M") and female ("F") satellite-tracked American alligators (Alligator mississippiensis) compared across wet and dry seasons and breeding and non-breeding periods in Water Conservation Area 3, Florida, USA (2014-2015).
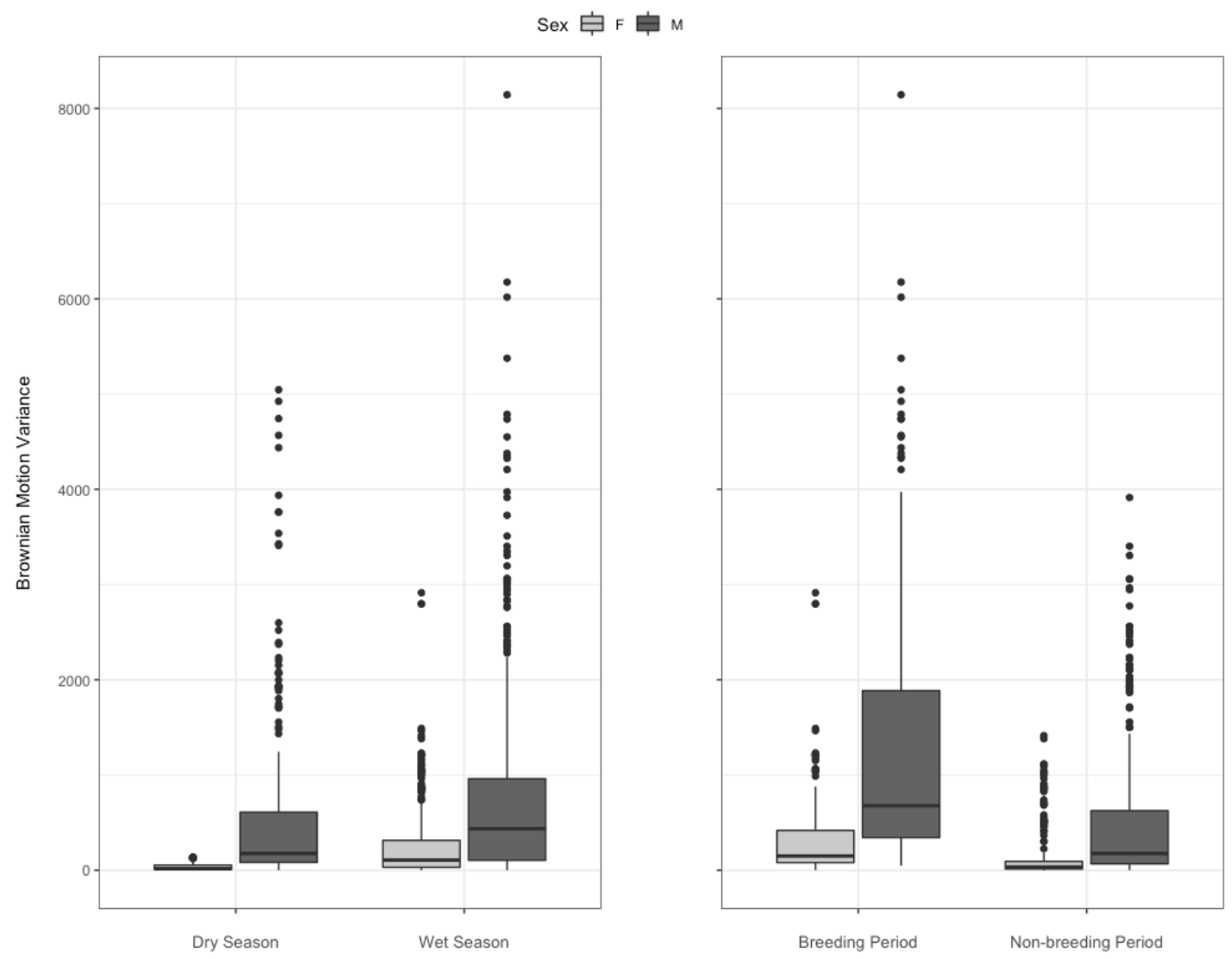
Figure 6: Carbon and nitrogen stable isotope values for blood plasma and scute tissues of satellite-tracked American alligators (Alligator mississippiensis) compared across males and females caught in both the wet and dry seasons in Water Conservation Area 3, Florida, USA (2014-2015).
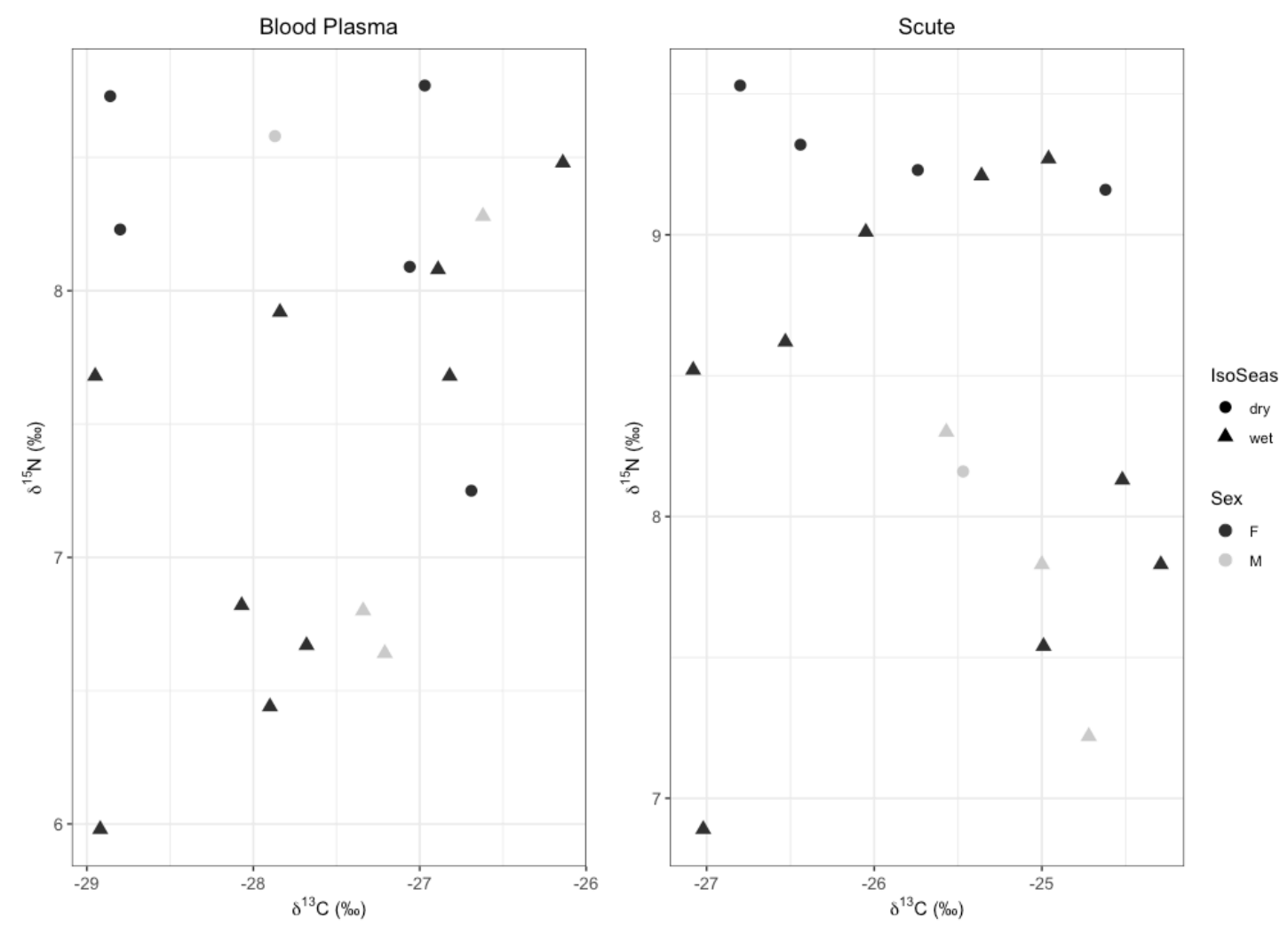
Figure 7: Population-level habitat selection ratios of satellite-tracked American alligators (Alligator mississippiensis) in Water Conservation Area 3, Florida, USA (2014-2015) at the scale of selecting home ranges within the study area and at the scale of selecting patches within home ranges. Habitats are abbreviated as "CA" is canal, "SG" is sawgrass marsh, "WV" is woody vegetation, "GP" is spikerush marsh, and "EV" is emergent aquatic vegetation.
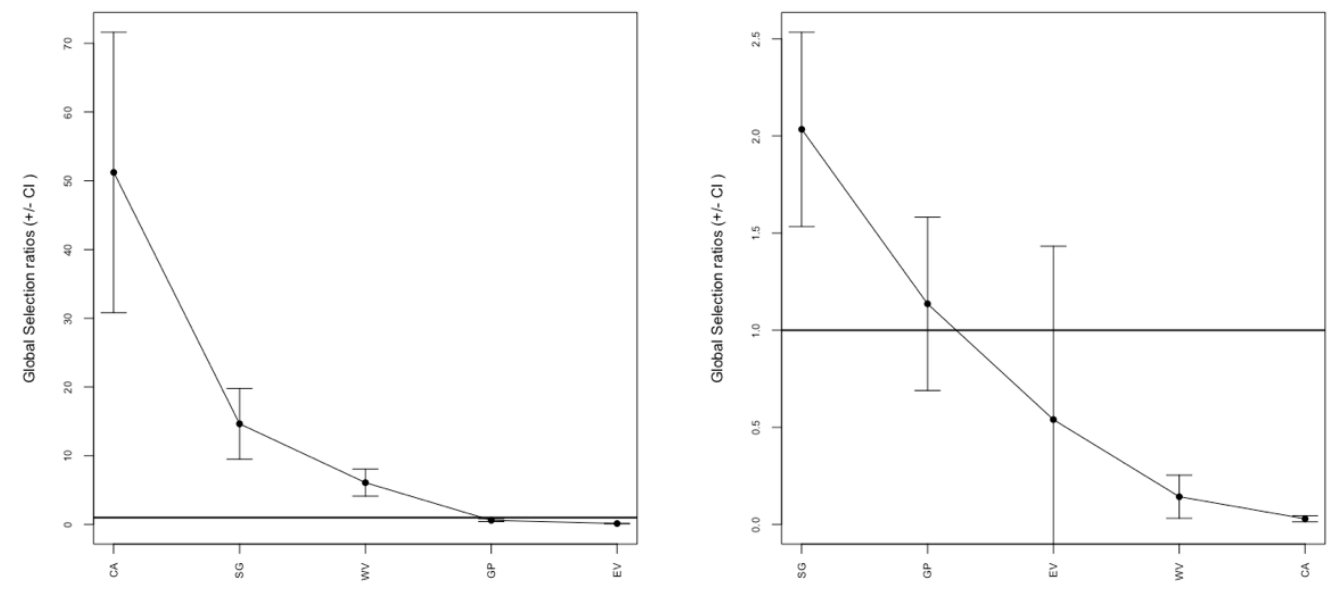
Table A1: Summary data for American alligators (Alligator mississippiensis) in Water Conservation Area 3, Florida, USA tracked using satellite telemetry (2014-2015) for which there were sufficient relocations.

\begin{tabular}{|c|c|c|c|c|c|c|c|c|c|c|}
\hline Individual & Tracking Period & $\begin{array}{c}\text { Tracking } \\
\text { Days }\end{array}$ & $\begin{array}{l}\text { Location } \\
\text { in WCA }\end{array}$ & $\begin{array}{c}\text { Total } \\
\text { Length } \\
\text { (cm) }\end{array}$ & $\begin{array}{c}\text { Weight } \\
\text { (kg) }\end{array}$ & Sex & $\begin{array}{c}\text { Filtered } \\
\text { Locations }\end{array}$ & $\begin{array}{c}\text { Wet } \\
\text { Season } \\
\text { Locations }\end{array}$ & $\begin{array}{c}\text { Dry } \\
\text { Season } \\
\text { Locations }\end{array}$ & $\begin{array}{c}\text { Fulton's K } \\
\text { (body } \\
\text { condition) }\end{array}$ \\
\hline 136253 & $4 / 30 / 2014-5 / 5 / 2015$ & 370 & $3 \mathrm{~B}$ & 249 & 42 & $\mathrm{M}$ & 274 & 182 & 91 & 1.92 (Poor) \\
\hline 136254 & $4 / 30 / 2014-4 / 25 / 2015$ & 360 & $3 \mathrm{~B}$ & 198 & 19 & $\mathrm{~F}$ & 125 & 98 & 26 & 1.93 (Poor) \\
\hline 136255 & $5 / 1 / 2014-5 / 6 / 2015$ & 370 & $3 \mathrm{~B}$ & 198 & 23 & $\mathrm{~F}$ & 68 & 59 & 8 & 2.23 (Good) \\
\hline 136256 & $5 / 2 / 2014-4 / 28 / 2015$ & 361 & $3 \mathrm{~B}$ & 177 & 14 & $\mathrm{~F}$ & 117 & 84 & 32 & 2.05 (Fair) \\
\hline 136257 & $5 / 1 / 2014-3 / 4 / 2015$ & 307 & $3 \mathrm{~B}$ & 207 & 21 & $\mathrm{~F}$ & 86 & 82 & 3 & 1.81 (Poor) \\
\hline 136258 & $5 / 2 / 2014-8 / 9 / 2014$ & 99 & $3 \mathrm{~B}$ & 167 & 13 & $\mathrm{~F}$ & 82 & 81 & 0 & 2.21 (Good) \\
\hline 142357 & $10 / 29 / 2014-10 / 19 / 2015$ & 355 & $3 \mathrm{~B}$ & 263 & 50 & M & 272 & 158 & 113 & 2.10 (Fair) \\
\hline 142358 & $11 / 4 / 2014-8 / 13 / 2015$ & 282 & $3 \mathrm{~B}$ & 173 & 14 & $\mathrm{~F}$ & 66 & 17 & 48 & 2.10 (Fair) \\
\hline 142359 & 10/30/2014-9/11/2015 & 316 & $3 \mathrm{~B}$ & 186 & 11 & $\mathrm{~F}$ & 59 & 21 & 37 & 1.08 (Poor) \\
\hline 142360 & $10 / 23 / 2014-10 / 10 / 2015$ & 352 & $3 \mathrm{~B}$ & 194 & 13 & $\mathrm{~F}$ & 55 & 22 & 32 & 1.39 (Poor) \\
\hline 142364 & $10 / 28 / 2014-2 / 16 / 2015$ & 111 & $3 \mathrm{~A}$ & 196 & 21 & $\mathrm{~F}$ & 42 & 6 & 35 & 2.14 (Good) \\
\hline 142365 & $10 / 27 / 2014-10 / 12 / 2015$ & 350 & $3 \mathrm{~A}$ & 198 & 19 & $\mathrm{~F}$ & 107 & 40 & 67 & 2.02 (Fair) \\
\hline 142367 & $11 / 1 / 2014-11 / 6 / 2015$ & 370 & $3 \mathrm{~A}$ & 206 & 28 & $\mathrm{M}$ & 280 & 199 & 80 & 1.94 (Poor) \\
\hline 142368 & $10 / 28 / 2014-10 / 8 / 2015$ & 345 & $3 \mathrm{~A}$ & 229 & 31 & $\mathrm{M}$ & 253 & 154 & 98 & 1.93 (Poor) \\
\hline
\end{tabular}


Figure A1: Water level ("gage height") in meters averaged across three sites (Eden 8, Site 69E, Site 71) plotted for the 30-days before and the first 30-days during an experimental water release in Water Conservation Area 3, Florida, USA that began on 4 November 2014 and ended 29 January 2015 (marked by the red dotted line). Data obtained from United States Geological Survey (USGS) Everglades Depth Estimation Network database at https://sofia.usgs.gov/eden/.

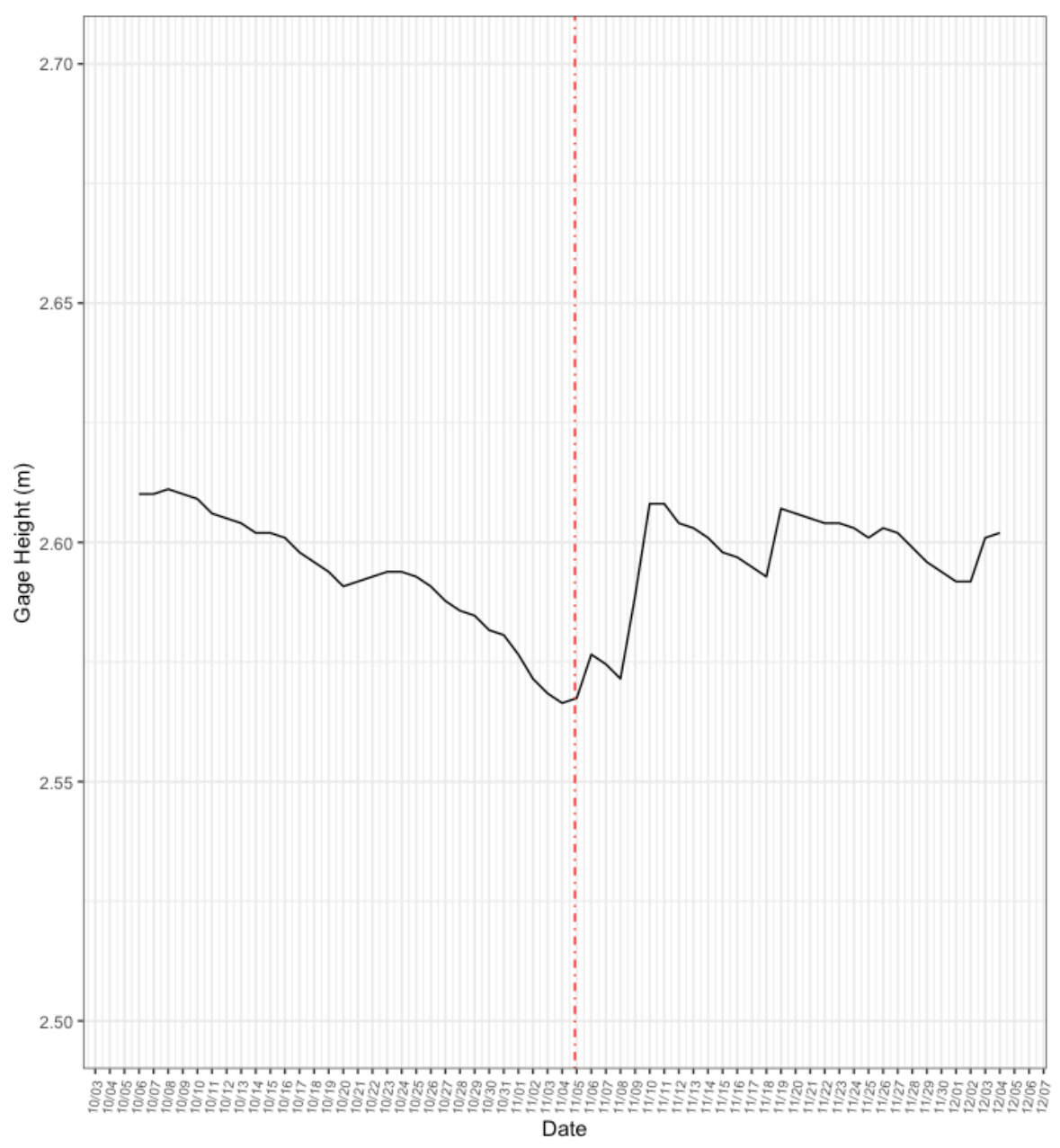




\section{CHAPTER IV}

TROPHIC STRUCTURE AND NUTRIENT ENRICHMENT OF PONDS

ENGINEERED BY AMERICAN ALLIGATORS IN AN OLIGOTROPHIC WETLAND 


\begin{abstract}
In food-web ecology, increasing focus has been placed on the ability of animals to influence nutrient limitation and habitat for basal autotrophic resources. These animalmediated bottom up effects arise through translocation and recycling of organic material by consumers and through physical disruption of sediment and other elements of habitat structure, termed ecosystem engineering. We know little about the net effects on foodweb structure and function when predators act as engineers. The American alligator (Alligator mississippiensis) is an abundant predator capable of dramatic modifications of physical habitat structure through the creation and maintenance of pond-like basins. Do these "alligator ponds" differ in nutrient status and community structure compared to the surrounding phosphorus-limited oligotrophic marsh? We used a halo design to sample three distinct habitats extending outward from ten ponds across a hydrological gradient. Our findings demonstrate that some alligator-engineered ponds are enriched relative to the marsh. We also observed differences in community composition related to habitat. For instance, we saw near absence of mat-forming periphyton in ponds. We also found that the edge habitat surrounding the pond contained the most diverse community of invertebrates likely driven by the abundance of dense emergent macrophytes not found in the pond or marsh habitats. However, not all ponds exhibited the same level of enrichment or trophic structure. We hypothesize that differences in local microtopography, alligator occupancy rates, and hydrological variables may influence the overall effects. Our findings suggest that alligators acting as ecosystem engineers influence the enrichment and trophic structure of oligotrophic freshwater marshes.
\end{abstract}




\section{Introduction}

A long-standing debate in food web ecology is the extent to which communities and ecosystems are structured from the bottom-up or from the top-down. Empirical and mathematical evidence supports the idea that primary productivity impacts plant biomass which controls the biomass of consumers (Hairston et al. 1960; Wilkinson and Sherratt 2016). Also, studies show that predators control herbivores and thus release plants from herbivory (top-down) (Matson and Hunter 1992). It is clear that both top-down and bottom-up pressures serve to organize food webs (Oksanen et al. 1981; Dyer and Letourneau 2003; Lynam et al. 2017). In many cases, nutrient addition appears to enhance primary productivity from the bottom up and result in increased biomass at higher trophic levels (Polis 1999). For instance, in pond mesocosms, nutrient addition led to higher algal biomass, primary production, and snail (grazer) biomass (Wojdak 2005). However, predators also exert top down impacts that can cause reductions in biomass at lower trophic levels (Schmitz et al. 2004, 2010; Estes et al. 2011). For instance, in the same pond mesocosms, the introduction of a voracious insect predator predictably decreased snail biomass and consequently enhanced algal production (Wojdak 2005). What is less understood is when each form of control is more or less important. The effects of both nutrient addition and predator introduction may depend on the structure of the food web such as antecedent abiotic conditions, food chain length, or the richness of grazers and predators (Lynam et al. 2017, Wojdak 2005, Spivak et al. 2007). For instance, a semiarid thorn scrub community appears to shift bottom-up and top-down control depending on resource limitation in dry periods and predator-prey interactions in wet periods (Meserve et al. 2003). In this study, top-down effects were recognized as 
predators effected abundance of small-mammals and small-mammals impacted plant biomass (Meserve et al. 2003). In the same long-term study, periodic El Niño Southern Oscillation events resulted in increased rainfall producing plant responses and increased biomass of herbivores (Meserve et al. 2003).

Increasing focus has been placed on the ability of animals to influence nutrient limitation and habitat for basal autotrophic resources. There are two major themes in animal-mediated bottom up effects on food webs: 1) effects of nutrient translocation and recycling including direct impacts and indirect consequences of altering behavior of prey that serve as nutrient vectors (Polis et al. 1997; Schmitz et al. 2010); and 2) effects from physical ecosystem engineering (Sanders et al. 2014). Theoretically, the interaction of the roles of predator and engineer have been poorly studied. For instance, we know little about the net effects on food-web structure and function when predators act as engineers (see Sanders and van Veen 2011).

Animal digestion can accelerate the rate of nutrient cycling by transforming more recalcitrant forms of nutrients to more labile ones, which are then released as excreta (Hobbs 1996). Through ingestion and excretion, consumers can recycle important nutrients including phosphorus $(\mathrm{P})$ and nitrogen $(\mathrm{N})$ at rates comparable to other sources and induce landscape-level heterogeneity in nutrient patterns (Vanni 2002, Schmitz et al. 2010). Organisms may move nutrients or energy against existing resource gradients and these subsidies can increase ecosystem productivity (Polis et al. 1997). Consumermediated recycling and translocation of nutrients can significantly alter energy and material fluxes and subsidize primary productivity and subsequently create trophic effects that may increase biodiversity and promote co-existence (Elser and Urabe 1999, Flecker 
et al. 2002). Large-bodied organisms have potential to generate landscape-level nutrient heterogeneity from excretion because of their capacity for long-distance movements, consumption of considerable biomass, and time lags between ingestion and excretion/egestion. For example, after feeding in deep waters, whales release iron-rich fecal plumes and nitrogen-rich urine in surface waters and enhance productivity at the surface (Roman and McCarthy 2010). Transporters create hotspots where the magnitude of nutrient fluxes are particularly high compared to the surrounding matrix (McClain et al. 2003). Resting areas or feeding sites, in particular, may feature increased nutrient regeneration from biodeposition. For instance, crows release about $27 \%$ of the annual nitrogen input of an evergreen forest mainly at roosting sites even though they were primarily feeding in a nearby urban landscape (Fujita and Koike 2007).

Consumers may also trigger bottom-up effects by modifying the physical environment as ecosystem engineers. Ecosystem engineers are organisms that make physical alterations to biotic or abiotic materials that are relatively significant at the landscape-level (Wright et al. 2002, Wright and Jones 2006). For example, dam building beavers (Castor canadensis) create ponds and wetlands that have long-term implications for large-scale drainage networks, affect species diversity, increase habitat heterogeneity, and are suspected to alter biogeochemical cycles (Naiman et al. 1994, Wright et al. 2002). Also, hippopotamuses (Hippopotamus amphibious) create trails during nighttime foraging excursions between rivers and riparian zones in southern Africa (Naiman and Rogers 1997) that increase habitat connectivity and provide movement corridors for diverse taxa (Naiman and Rogers 1997). Engineering effects may result in both negative 
and positive impacts on primary producers, but generally they are net positive (Sanders et al. 2014; Jones et al. 1997).

The American alligator (Alligator mississippiensis) is an abundant predator in most aquatic ecosystems throughout the southeastern United States. They are considered opportunistic generalist predators feeding across multiple trophic levels (Delany and Abercrombie 1986, Rosenblatt et al. 2015). In addition, growing evidence suggests that alligators affect abiotic conditions through nutrient transport and as ecosystem engineers. For instance, alligators may enhance nutrient cycling by facilitating nutrient transport across productivity gradients (Rosenblatt and Heithaus 2011) and the aquatic-terrestrial matrix (Subalusky et al. 2009) through cross-ecosystem movements. The contribution of these movements to overall nutrient fluxes, however, remains unknown. Alligators can also physically modify the environment, perhaps most significantly through their creation and maintenance of "alligator ponds" (Kushlan 1974, Campbell and Mazzotti 2004, Palmer and Mazzotti 2004). In their ponds, alligators repeatedly remove vegetation and push sediment into the banks with their claws, snout, and tail. This disturbance of soil may affect establishment and recruitment of plant species by redistribution and regeneration of nutrients, particularly the remobilization of legacy $\mathrm{P}$ stored in sediment (Kushlan and Hunt 1979, Palmer and Mazzotti 2004). The banks of alligator ponds provide higher elevation substrate used as nest sites for other reptiles (Kushlan 1974, Kushlan and Kushlan 1980) and provide a hydrologic relief gradient for woody vegetation (Palmer and Mazzotti 2004). As a result of these activities, alligator ponds have increased habitat heterogeneity and thus, may have higher species richness compared to the surrounding hydroscape (Kushlan 1974, Campbell and Mazzotti 2004, 
Palmer and Mazzotti 2004). Ponds range in size and shape, but they can hold water even in severe marsh drydown and function as refuges for fishes and invertebrates, which in turn may be used as foraging sites for other animals in the dry season (Kushlan and Kushlan 1980, Campbell and Mazzotti 2004, Brandt et al. 2010). Animals, including the alligators themselves, may transport nutrients and organic matter from the surrounding marsh and concentrate it in the pond. This enrichment may be significant given that Everglades wetlands are sensitive to loading and respond rapidly to short-term, low-level P enrichment with noticeable differences in periphyton and flocculent detritus (Noe et al. 2002). For instance, in a P-limited system like the freshwater Everglades, additions as small as $3-13 \mu \mathrm{g} \mathrm{L}^{-1}$ can shift the basal resources of the food web from detrital- to algaldominance (Noe et al. 2002, Gaiser et al. 2005).

Our goal was to determine if alligator-engineered ponds differ in nutrient status and community structure compared to the surrounding marsh. We predicted that alligator ponds are P-enriched particularly in the dry season because of physical bioturbation of legacy $\mathrm{P}$ and the concentration of biological activity recycling $\mathrm{N}$ and $\mathrm{P}$. We also investigated the hypothesis that alligator ponds are associated with increased species richness and abundance due to this enrichment and increased habitat heterogeneity. We predicted that this relationship is stronger in the dry season when marsh-dwelling animals are forced into the aquatic refuges.

\section{Methods}

Study site and design

Shark River Slough and Taylor Slough, in Everglades National Park, are the two 
major drainage basins of freshwater through the Everglades to the Gulf of Mexico. Taylor Slough is a smaller, drier conduit than Shark River Slough (Kotun and Renshaw 2014). Both sloughs are wet prairie habitats dominated by spikerush (primarily Eleocharis cellulosa) and large stocks of periphyton (Turner et al. 1999). Interspersed throughout these sloughs are alligator ponds which are generally open water areas deeper than the surrounding marsh and ringed by dense and distinct assemblages of emergent vegetation (Palmer and Mazzotti 2004). The Everglades is marked by interannual variation in rainfall and distinct seasons where roughly $75 \%$ of the annual rainfall occurs May through October (Gaiser et al. 2012).

We sampled ten active alligator ponds with five each in Shark River Slough and Taylor Slough (Figure 1). There are three distinct habitats associated with alligator ponds (Palmer and Mazzotti 2004) extending outwards from the center of the pond: 1) a pool or semi-open water habitat (hereafter "pond"), 2) a dense ring of vegetation immediately surrounding the pond (hereafter "near-pond"), and 3) the adjacent marsh. Each site was sampled in November-December 2018 (high water period, referred to as "wet season") and March-April 2019 (low water period, referred to as "dry season").

\section{Water and flocculent detrital matter}

We used an acid washed bottle, to collect $125 \mathrm{~mL}$ of water from approximately midway in the water column in each habitat. The bottle was rinsed with water at the sampling location several times before final collection and care was taken to avoid air inside the sample container. Bottles were emersed inverted, turned upright to fill, and capped underwater. The samples were placed on ice and refrigerated until they were 
analyzed within two weeks. We also took samples of flocculent detrital matter ("floc") in three different locations within each habitat and then aggregated these into a single sample. Floc was obtained with a $5 \mathrm{~cm}$ diameter piston corer and waiting approximately 3 minutes as the floc settled to the bottom of the aqueous layer following Noe et al. (2002). We removed the top water and then transferred all pourable floc into a sample container. Floc samples were immediately placed on ice and frozen until laboratory analysis. We measured total phosphorus using dry combustion and colorimetric methods for floc and water samples (Solórzano and Sharp 1980, Noe et al. 2002). In the Everglades freshwater marsh, TP is a direct indicator of primary productivity (McCormick et al. 2002).

We compared wet season water TP across all three habitats and both sloughs using a repeated measures analysis of variance. Habitats within sites were treated as the repeated measure and the within-site profile of differences among habitats was the fundamental unit of observation for the hypothesis tests. We checked for outliers and extreme outliers using 1.5 and 3 times the interquartile range, respectively, added and subtracted from the $75 \%$ and $25 \%$ quartiles. Because of the presence of extreme outliers in each group, we also used the Friedman test to check the sensitivity of our overall results. Logistical issues prohibited the collection of water samples at one site in Taylor Slough (AH9) in the 2019 dry season. During the dry season, we were only able to collect water in pond and marsh habitats; only one near-pond habitat had enough water to collect a sample without floc or sediment contamination. We used a repeated measures analysis of variance to compare mean TP across marsh and pond habitats for the dry season. We 
also compared wet and dry season mean TP for marsh and pond habitats using paired $t$ tests.

We used a repeated measures analysis of variance to compare floc TP across habitats and sloughs. The test included site as subject with slough as a between-subject factor and habitat as within-subject factors. We also considered the interaction of slough and habitat. For significant sources and interactions, we estimated marginal least-squares means of all contrasts.

\section{Basal resources}

We collected floating mat-forming and epiphytic mat-forming periphyton by filling a perforated 2,000 mL graduated cylinder with samples from multiple areas within a habitat, removing the water and placing directly in a container. We used a Fisher's exact test for each season to determine if there was a relationship between habitat and the presence of mat-forming periphyton. We simulated p-values from 2,000 replicates because of small sample sizes. We also report Pearson's chi-squared test statistic for sensitivity. We then used pairwise comparisons with a Bonferroni adjustment to find differences between habitats. We also performed these tests for the presence of Nostoc spp. colony and associated community that forms a gelatinous sphere.

All dominant emergent vascular plant species in each habitat at all sites were collected as a composite made of leaves or mid-stem from multiple individuals in multiple areas. We also collected aggregates of all dominant submerged non-vascular plants, namely Utricularia spp., and submerged vascular plants. All samples were identified and then stored on ice until frozen in the laboratory. Separately, we used 
Fisher's exact tests to determine if there were relationships between habitat and the presence of the most commonly observed plant species. We simulated p-values from 2,000 replicates. We also report Pearson's chi-squared test statistic for sensitivity. We then used pairwise comparisons with a Bonferroni adjustment to find differences between habitats. We calculated species richness for the plant communities. To compare richness across habitats and visits, we used a repeated measures analysis of variance. The test included site as subject with slough as a between-subject factor and season and habitat as within-subject factors. We considered interactions of all three factors pairwise and threeway. For significant sources and interactions, we estimated marginal least-squares means of all contrasts. We developed a Morisita-Horn distance matrix and used a permutational multivariate analysis of variance (PERMANOVA) set to 999 permutations to compare community composition among habitats and visits. We used post hoc pairwise comparisons on a binary distance matrix to further investigate significant effects of habitat. We performed a simper analysis with 999 permutations to investigate influential species in explaining dissimilarities between factor levels (Clarke and Warwick 2001). Using non-metric multidimensional scaling, we explored differences in community composition by slough, habitat, and season.

\section{Consumer communities}

We placed Brakke’s (1976) modified Whiteside-Williams (1975) samplers (16 funnel traps in a $4 \times 4$ array) on top of the sediment for 24-hours to capture zooplankton as they emerged at night to swim into the water column. We stored these samples on ice for transport to the laboratory, where they were stored in a refrigerator until processing. 
Collections were sorted and counted under a dissecting microscope and organisms were identified to taxonomic level (i.e., family or genus).

We performed three $1 \mathrm{~m}^{2}$ throw trap samples in each habitat at each site $(9$ total throws per site). We were not able to sample at each habitat of every site and every visit because of the limitations of throw traps in cases where water depth was less than $5 \mathrm{~cm}$ or greater than $1 \mathrm{~m}$ or vegetation stem was density greater than 200 stems $\mathrm{m}^{2}$ (Jordan et al. 1997). Five minnow traps were placed in each habitat for approximately 4 hours. We also used omni-directional drift fences with minnow traps left overnight for two consecutive 24-hour periods with collection at each 24-hour period (Obaza et al. 2011). Two fences were deployed in the marsh and one fence was placed in the near-pond habitat. Drift fences were not set in the pond because of ethical and logistical concerns of blocking alligator movement. All animals collected were euthanized with a lethal dose of MS-222 prior to being stored on ice. Animals were identified to species, counted, measured to the nearest $\mathrm{mm}$, weighed to the nearest $\mathrm{mg}$, and sexed when possible in the laboratory.

We created rarefaction curves with confidence intervals for each habitat and for sampling of both benthic invertebrates and aquatic consumers (Gotelli and Cowell 2011). We calculated taxa richness and developed dominance-diversity curves to highlight differences among habitats. To compare richness across habitats and visits, we used a repeated measures analysis of variance. The test included site as subject with slough as a between-subject factor and season and habitat as within-subject factors. We considered interactions of all three factors pairwise and three-way. For significant sources and interactions, we estimated marginal least-squares means of all contrasts. We removed taxa with fewer than five individuals for further community composition comparisons. 
We developed a Morisita-Horn distance matrix and used a PERMANOVA set to 999 permutations to compare community composition among habitats and visits. We used post hoc pairwise comparisons on a Canberra distance matrix for count data to further investigate significant effects of habitat. We performed a simper analysis with 999 permutations to investigate influential species in explaining dissimilarities between factor levels. Using non-metric multidimensional scaling, we explored differences in community composition by slough, habitat, and season.

\section{Results}

\section{Water and floc}

Mean water TP had considerable variation within each habitat during the wet season $\left(\right.$ Figure $2 ;$ marsh $=1.2 \pm 2.6$, near-pond $=5.4 \pm 9.4$, pond $=1.6 \pm 3.3 \mu \mathrm{mol} \mathrm{L}^{-1}$ ) and the dry $\left(\operatorname{marsh}=1.6 \pm 1.8\right.$, pond $\left.=2.7 \pm 2.6 \mu \mathrm{mol} \mathrm{L}^{-1}\right)$. In the wet season, the nearpond habitat TP was elevated compared to the pond and marsh for five of ten sites and LJB exhibited an extreme outlier in the near-pond habitat being more than three times higher than the next highest value (Figure 2). However, four of the nine ponds (LJB, $\mathrm{AH} 5, \mathrm{AH} 3$, and $\mathrm{CPB}$ ) had elevated water column TP in the pond compared to marsh. We did not observe differences in water column TP between sloughs or among habitats in either season (Table 1). Mean TP did not differ between seasons in marsh $\left(\mathrm{t}_{8}=-0.25, p=\right.$ $0.81)$ or pond habitats $\left(\mathrm{t}_{8}=-0.63, p=0.55\right)$. A considerable number of our samples were above the $10 \mu \mathrm{g} \mathrm{P} \mathrm{L}^{-1}$ threshold for periphyton mat loss (see Gasier et al. 2005; wet season, $50 \%, 15 / 30$; dry season, $61 \%, 11 / 18$ samples). Eight of these samples above the threshold were in locations where intact periphyton mats were present. 
During the wet season, floc TP averaged $16.3 \pm 4.8 \mu \mathrm{mol} \mathrm{L}^{-1}$ for the marsh, $24.6 \pm$ $7.9 \mu \mathrm{mol} \mathrm{L}{ }^{-1}$ for the near-pond, and $32.8 \pm 8.7 \mu \mathrm{mol} \mathrm{L}^{-1}$ for the pond (Figure 3). TP in the wet season floc was different among habitats but did not differ between sloughs (Table 2). In addition, the interaction of slough and habitat was not significant. Post hoc tests revealed that all three habitats were different from each other (Table 3). Samples were collected for the dry season but unfortunately were not able to be run because of the COVID-19 pandemic.

\section{Periphyton and algal communities}

There was a relationship between habitat and the presence of periphyton in the wet season $\left(\chi^{2}=17.1, p<0.01\right)$ and dry season $\left(\chi^{2}=21.8, p<0.01\right)$. For both seasons, mat-forming periphyton were more common in the marsh habitat (Fisher's exact pairwise; marsh-pond, $p<0.01$; marsh-near-pond, $p<0.01$ ) compared to near absence in the near-pond and pond habitats $(p=1.00)$. In the wet season, periphyton was found in the marsh habitat at each of our ten sites and only two near-pond habitats and two pond habitats. Six sites had both floating and epiphytic mat-forming periphyton in the marsh and two had only epiphytic mats and another two had only floating mats. In the dry season, periphyton was only found in the marsh habitat and was collected at each site except ponds CATB and AH9. Two sites had both floating and epiphytic mat-forming periphyton while the other six marshes had only floating mats. We found Nostoc communities in six pond, two near-pond, and two marsh habitats in the wet season. In the dry season, we observed it in only four pond and one marsh habitat. There was no 
relationship between habitat and the presence of Nostoc communities in the wet $\left(\chi^{2}=4.8\right.$, $p=0.12)$ or dry season $\left(\chi^{2}=6.2, p=0.10\right)$.

\section{Plant communities}

We identified 21 species of plants (Table 4) present at least at one location. In surveys from both seasons, the marsh habitat exhibited 15 species, near-pond had 13 species, and the pond habitat contained 18 species. Three species were only observed at one site in one season. We did not estimate relative abundance or biomass of each species, but the most commonly observed plants across sites and habitats were Eleocharis cellulosa, Panicum hemitonum, Sagitarria lancifolia, Cladium jamaicense, and Utricularia spp. All marsh sites had E. cellulosa present in both seasons whereas it was detected less at the near-pond and pond visits $\left(\chi^{2}=12.9\right.$; Fisher's exact pairwise; marshnear-pond and marsh-pond, $p<0.01)$. Utricularia spp. were observed more often in the marsh compared to other habitats $\left(\chi^{2}=26.1\right.$; Fisher's exact pairwise; marsh-pond and marsh-near-pond, $p<0.01$; pond-near-pond, $p=0.04)$. In the near-pond and pond habitats, Peltandra virginica $\left(\chi^{2}=12.0\right.$; Fisher's exact pairwise; marsh-pond and marshnear-pond, $p<0.01$; pond-near-pond, $p=1)$ and Pontedaria cordata $\left(\chi^{2}=31.6\right.$; Fisher's exact pairwise; marsh-pond and marsh-near-pond, $p<0.01$; pond-near-pond, $p=0.82$ ) were present despite not being found in any marsh surveys. P. hemitonum $\left(\chi^{2}=0.5, p=\right.$ 0.84), S. lancifolia $\left(\chi^{2}=5.8, p=0.06\right)$, Tyhpa domingensis $\left(\chi^{2}=6.1, p=0.06\right)$, and $C$. jamaicense $\left(\chi^{2}=0.1, p=1\right)$ presence was not different among habitats. The analysis of 
variance did not reveal any significant effects of habitat, season, or slough on plant richness (Table 5).

The PERMANOVA revealed that slough, habitat, and the interaction of slough and habitat predicted dissimilarity observed in the community while season and all other interactions were not significant (Table 6). Post hoc pairwise comparisons of habitat show that composition of marsh and pond (pseudo $F=8.0, \mathrm{r}^{2}=0.17, p<0.01$ ) and marsh and near-pond (pseudo $F=8.9, \mathrm{r}^{2}=0.19, p<0.01$ ) differed. However, pond and nearpond community composition did not differ (pseudo $F=1.7, \mathrm{r}^{2}=0.04, p=0.09$ ). Simper revealed the most influential species for the overall dissimilarities between communities, and in each case, it included a suite of eight or nine species. Dissimilarities between marsh and near-pond were mostly explained by a suite of species including Utricularia foliosa (cumulative contribution, 12\%), Pontedaria cordata (22\%), Sagitarria lancifolia (32\%), Panicum hemitonum (40\%), Utricularia purpurea (49\%), Cladium jamaicense (57\%), Eleocharis cellulosa (65\%), and Peltandra virginica (72\%). Dissimilarities between marsh and pond were largely explained by Pontedaria cordata (13\%), Utricularia foliosa (22\%), Eleocharis cellulosa (29\%), Utricularia purpurea (37\%), Panicum hemitonum (45\%), Cladium jamaicense (52\%), Sagitarria lancifolia (59\%), Peltandra virginica (66\%), and Paspaladium geminatum (72\%). Dissimilarities between near-pond and pond were explained mainly by Sagitarria lancifolia (11\%), Eleocharis cellulosa (21\%), Peltandra virginica (31\%), Panicum hemitonum (41\%), Cladium jamaicense (50\%), Pontedaria cordata (59\%), Utricularia foliosa (67\%), and Typha domingensis (73\%). The difference between Taylor and Shark River sloughs was explained primarily by Sagitarria lancifolia (10\%), Peltandra virginica (20\%), Cladium 
jamaicense (29\%), Pontedaria cordata (39\%), Utricularia foliosa (47\%), Panicum

hemitonum (56\%), Eleocharis cellulosa (64\%), and Utricularia purpurea (71\%). We also ran a separate permutational model for the wet season only including floc total phosphorus (Table 6). This model revealed that the interaction of slough and TP was a significant factor while TP alone was not. The non-metric multidimensional scaling for community composition revealed overlap and compositional similarity among all three habitats, but the marsh was almost separated from near-pond and pond communities (Figure 4).

\section{Benthic invertebrate communities}

We collected 9,985 invertebrates from the funnel traps. Animals were divided into 16 taxonomic groups based on identification to the lowest resolution (Table 7). The most abundant taxonomic groups were: Ostracoda (39\% of total individuals collected), Copepoda (23\%), Trombidiformes (10\%), Cladocera (10\%), Amphipoda (9\%), Diptera (5\%), and Ephemeroptera (2\%) (Table 7). The other nine groups were less abundant (Table $7 ; 11 \%$ total and $<1 \%$ individually). For community analyses, we removed three groups (Arguloidae, Coleoptera, and Mysidae) that were only observed a single time in the dataset and decapods that were seen as singletons at a few sites.

The rarefaction curve showed that both pond and marsh were approaching an asymptote while the near-pond habitat was not (Figure 5). Considerable overlap existed between the $95 \%$ confidence intervals between the habitats. Season and interaction of season and habitat were significant factors of benthic invertebrate richness (Table 8). Comparing means across the contrasts of the interaction (Table 9), we saw that near-pond 
richness was five species greater in the wet season compared to dry season. We also observed greater richness of nearly five species in the dry-season pond compared to nearpond. Wet season marsh mean richness was nearly six species more than dry season nearpond richness. Among all habitats, wet season richness was greater than dry season richness $\left(d=2.0 \pm 0.6(\mathrm{SE}), \mathrm{t}_{8}=3.5, p<0.01\right)$. Dominance-diversity curves reveal that habitats have similar ranks of species (Figure 6). Catches of Amphipoda were particularly high in the marsh and almost absent from the pond. Catches of Ostracoda, Copepoda, and Trombidiformes were greater for the pond than other habitats.

The PERMANOVA revealed that slough, season, and habitat predicted dissimilarity observed in the community (Table 10). Community compositions between marsh and pond (pseudo $F=2.2, \mathrm{r}^{2}=0.06, p=0.02$ ) and pond and near-pond (pseudo $F$ $=2.1, \mathrm{r}^{2}=0.07, p=0.03$ ) were different. Marsh and near-pond were not different (pseudo $\left.F=0.9, \mathrm{r}^{2}=0.03, p=0.55\right)$. Simper revealed the most influential species for the overall dissimilarities between communities. Dissimilarities between marsh and near-pond were explained by Ostracoda (cumulative contribution, 28\%), Copepoda (50\%), Amphipoda (64\%), and Cladocera (76\%). Dissimilarities between marsh and pond and between nearpond and pond were explained by Ostracoda (marsh-pond, 39\%; near-pond-pond, 36\%), Copepoda (62;61\%), and Trombidiformes (73; 73\%). For the sloughs, Ostracoda (36\%), Copepoda (57\%), and Trombidiformes (70\%) explained dissimilarities. The same pattern emerged for seasons, with Ostracoda (36\%), Copepoda (60\%), and Trombidiformes (71\%) explaining dissimilarities. Differences among groups in simper analyses are often explained by the relationship of higher abundance and higher variance. Indeed, species identified in these analyses were the most abundant. We also ran a separate model for the 
wet season only including floc total phosphorus, which was not a significant factor (Table 10). Non-metric multidimensional scaling showed compositional similarity among all three habitats, but the pond ellipse was the most separated from near-pond and marsh (Figure 7).

\section{Aquatic consumer communities}

For sampling across all three sampling methods, both seasons, and all habitats, we identified a total of 38 vertebrate species and 34 invertebrate taxa and captured 7,875 individuals (Tables 11, A1). For multivariate analyses, we removed rare taxa with less than five individuals resulting in the removal of 24 total taxa. Marsh drying required helicopter access to Taylor Slough during the dry season sampling. As a result, logistics did not permit for complete consumer food-web sampling to be conducted at some sites. In addition, $\mathrm{AH} 11$ pond in the wet season and $\mathrm{CATB}$ pond in both seasons were too deep to throw trap. Overall, we deployed 129 throw traps, 225 minnow traps, and 45 drift fences across both seasons.

Rarefaction curves for the total dataset show that pond sampling did not reach an asymptote (Figure 8). However, subsetting to account for unequal effort showed that all three habitats were relatively close to an asymptote. Thus, we divided the total dataset to account for unequal sampling effort between sloughs and seasons to determine predictors of richness. For each dataset, rarefaction curves for near-pond and marsh had considerable overlap of $95 \%$ confidence intervals. Pond richness was lower than the other habitats. When considering unequal sampling between seasons, habitat but not slough was significant (Table 12). Post hoc tests showed that mean richness in the marsh and 
pond and mean richness in the near-pond and pond were different (Table 13). In fact, marsh and near-pond had on average almost 11 more taxa than the pond habitat. When accounting for unequal sampling between sloughs, habitat and the interaction of season and habitat were significant factors (Table 12). Using post hoc tests on all contrasts of season and habitat (Table 13), we found that mean richness in the dry season marsh and near-pond was different. Also, mean richness in the near-pond and pond was different in the dry season.

We used datasets on each method to look at dominance-diversity relationships between habitats. Across all methods, Palaemonetes paludosus, Lucania goodei, and Gambusia holbrooki were the most abundant taxa per CPUE across seasons and among habitats (Figure 9). Overall CPUE was low for pond. For the throw traps, mean CPUE for G. holbrooki was high for the pond and L. goodei was low for the near-pond (Figure 10). The highest mean CPUE across all habitats was $P$. paludosus. In the marsh, mean CPUE for $P$. paludosus was four times higher than the next most abundant taxa and abundance was higher for the dry season than the wet season. Using unbaited minnow traps, $P$. paludosus and L. goodei were dominant across habitats (Figure 11). Mean CPUE was especially high for P. paludosus and L. goodei in the marsh during the wet season. During the dry season, catches in the marsh were dominated by G. holbrooki, Jordanella floridae, and Fundulus chrysotus. In the pond, minnow traps contained mostly $P$. paludosus and L. goodei. Drift fence dominance-diversity curves show that $P$. paludosus dominated catches in both the wet and dry seasons in the near-pond (Figure 12).

We used each data subset separated to account for unequal sampling between sloughs or seasons. For the wet season dataset, the PERMANOVA revealed that slough, 
habitat, and the interaction of slough and habitat predicted dissimilarity observed in the community (Table 14). Considering only the effect of habitat, community compositions between marsh and pond (pseudo $F=3.4, \mathrm{r}^{2}=0.16, p<0.01$ ), pond and near-pond (pseudo $F=3.1, \mathrm{r}^{2}=0.15, p<0.01$ ), and marsh and near-pond (pseudo $F=1.9, \mathrm{r}^{2}=0.10$, $p=0.03)$ were different. Simper revealed the most influential species for the overall dissimilarities between communities. Dissimilarities between habitats were explained overwhelmingly by the most abundant taxa, P. paludosus and L. goodei. Pelocoris femoratus was important in differentiating marsh and pond as well as marsh and nearpond while the differences between near-pond and pond included Coenagrionidae, Araneae, and Amphipoda. For sloughs, dissimilarities were explained by P. paludosus (cumulative contribution, 23\%), Lucania goodei (33\%), P. femoratus (39\%), and Celithemis spp. (45\%). We also ran a separate permutational model including floc total phosphorus, which was not a significant factor (Table 14). For the Shark River Slough dataset, the PERMANOVA revealed that habitat and the habitat and season interaction predicted dissimilarity observed in the community (Table 14). Not considering the interaction, community compositions between marsh and pond (pseudo $F=3.0, \mathrm{r}^{2}=0.15$, $p<0.01$ ) and pond and near-pond (pseudo $F=2.5, \mathrm{r}^{2}=0.13, p<0.01$ ) were different but not marsh and near-pond (pseudo $F=1.4, \mathrm{r}^{2}=0.07, p=0.07$ ). Simper revealed the most influential species for the overall dissimilarities between communities. Dissimilarities between habitats were explained by the most abundant taxa, P. paludosus, G. holbrooki, and L. goodei. P. femoratus were important in differentiating marsh and pond as well as marsh and near-pond while the differences between near-pond and pond were attributed to Heterandria formosa, Araneae, and Poecilia latipinna. Separate non-metric 
multidimensional scalings, showed there was compositional similarity among the nearpond and marsh with considerable separation of the pond habitat, especially in the Shark River Slough dataset (Figure 13).

\section{Discussion}

I observed consistent differences along the pond, near-pond, and marsh habitat gradient in both sloughs consistent with hydrological and nutrient effects of alligator residence (Kushlan 1974; Kushlan and Hunt 1979; Campbell and Mazzotti 2004; Palmer and Mazzotti 2004). Across the three habitats, we observed differences in P-enrichment and dissimilarities in aquatic plant and animals communities likely related to nutrient availability and habitat structure enhanced by alligators in the near pond and pond habitats. Alligator activities are known to create the gradients we sampled, and our findings suggest that alligators acting as ecosystem engineers influence the enrichment and trophic structure of oligotrophic freshwater marshes. The maintenance and nutrient subsidies provided to these ponds is ecologically significant in nutrient-poor freshwater marshes of the Everglades, causing shifts in community structure and potentially emergent ecosystem properties.

As predicted, we saw elevated P levels in the floc of pond, intermediate levels in the near-pond, and lower levels in the marsh habitat. This is evidence that ponds, which exhibited TP concentrations nearly double than those in the marsh, are nutrient enriched. Floc, the unconsolidated layer of particulate matter, and the underlying soil in the oligotrophic Everglades receive primarily decaying periphyton and macrophytes (Noe et al. 2003; Neto et al. 2006; Childers et al. 2003). Organic-matter-rich floc is 
reincorporated in biota through its role as a basal source for the detrital food web (Williams and Trexler 2006; Belicka et al. 2012). Field experiments in oligotrophic wetlands reveal that floc stores much of the accumulated $\mathrm{P}$ when dosed compared to water, periphyton, and surface water (Noe et al. 2003). There may be a temporal component that could be evaluated in a future study where the concentration of TP may change within seasons for both water and floc. In fact, Kushlan and Hunt (1979) observed increased phosphate, nitrite, and nitrate during a massive fish kill in an alligator pond in the late dry season to wet season transition period. Unfortunately, we were only able to evaluate floc in the wet season, but we predict that pond TP would be higher in the late dry season because of accumulation from excretion and egestion by the increased abundance of aquatic fauna.

Water column TP did not demonstrate nutrient enrichment of pond or near-pond habitats across all sites. However, some of our sites did show orders of magnitude higher $\mathrm{TP}$ in pond water compared to marsh water in the dry season. At these sites, increased biological activity and nutrient recycling through excretion and egestion may be increasing the concentration of $\mathrm{P}$ in the water beyond what can be absorbed and used by algae and other biota. Ponds may be in different stages of enrichment as a result of differences in biological variables like alligator activity or geophysical factors like basin depth (Campbell and Mazzotti 2004). In hypereutrophic conditions, elevated water column TP may be detectable (Hudson et al. 2000). However, water column TP may not be a reliable indicator of eutrophication at lower levels of enrichment because $\mathrm{P}$ is readily concentrated into biota (Gaiser et al. 2004; Hudson et al. 2000). For instance, in an Everglades flume study, periphyton TP was an excellent metric for distance from P 
source, but water column TP concentrations were not correlated with experimental P load (Gaiser et al. 2006). Future work could evaluate the stoichiometry of primary producers like periphyton and vascular plants and subsequent trophic transfer to consumers. An experimental loading treatment could evaluate the hypothesis of differential uptake and storage of nutrients by primary producer communities and that it scales to higher trophic levels from consumption and turnover/storage rates.

Pond and near-pond habitats were less likely to have mat-forming periphyton present than the marsh indicating nutrient enrichment. Periphyton mats generally break apart when P-loading exceeds $10 \mu \mathrm{g} \mathrm{L}^{-1}$ (Gasier et al. 2005; Gasier 2009). One study reported that periphyton biomass was 6- to 30-times lower and even absent in some eutrophic compared to oligotrophic $\left(<10 \mu \mathrm{g} \mathrm{P} \mathrm{L}^{-1}\right.$ in water column) sites in the northern Everglades (McCormick et al. 1998). We also observed fewer mats in the dry season compared to the wet season. In oligotrophic areas, there is a strong seasonal shift in both total biomass and periphyton community composition from cyanobacteria in the wet to diatoms in the dry season (McCormick et al. 1998). One interesting avenue for future studies of alligator pond habitats would be to identify algal community composition given that different species and assemblages may be associated with changes in ecosystem functions like primary productivity (Gaiser et al. 2006). In our study we were only able to separate and identify the visually unique, Nostoc spp. colonies, which sometimes form a gelatinous sphere (Komarek et al. 2015). These Nostoc communities are associated with increasing $\mathrm{P}$ concentrations and may indicate more eutrophic conditions (Komarek et al. 2015). Additionally, physical disturbances including removal of epiphytes (McCormick and Stevenson 1991) and overlying sediment (Pringle et al. 
1993) which are likely created by alligator activities have been shown to enhance nutrient uptake and light availability for certain algae species resulting in increased algal biomass (McCormick 1994). Though these Nostoc communities were found more often in the pond compared to other habitats across both seasons, statistically we found no relationship between habitat and its presence potentially reflecting our small sample size.

Plant communities differed from the marsh compared to the near-pond and pond. We also found that community composition differed between sloughs. Though we did not find a difference in species richness between habitats, some species were more associated with a particular habitat. Marsh habitats were often dominated by Eleocharis cellulosa (spikerush). Spikerush is one of the most abundant plants in the freshwater Everglades and characterizes wet prairie habitats, thus it is not surprising that it was associated with the marsh habitat (Busch et al. 1998). Marsh habitats more frequently had Utricularia spp. (bladderwort) than other habitats. Periphyton mats in the Everglades are attached and form around the floating stems of the carnivorous bladderworts (Busch et al. 1998). Nearpond and pond habitats were characterized by Peltandra virginica (green arrow arum) and Pontedaria cordata (pickerelweed). Green arrow arum, interestingly, may be $\mathrm{N}$ rather than P limited in most circumstances (Daoust and Childers 1999). Though we did not test for TN, especially during the dry season, pond habitats may have increased $\mathrm{N}$ forms from excretion and egestion (Kushlan and Hunt 1979). Thus, TN may be diffused or actively transported to near-pond habitats by biota. While pickerelweed is expected to respond to P-enrichment (Daoust and Childers 1999), its abundance may be also dominated by other factors such as water depth. Both green arrow arum and pickerelweed have also been associated with alligator ponds and near-pond habitats in other studies 
(Palmer and Mazzotti 2004; Campbell and Mazzotti 2004). Near-pond habitats were densely vegetated areas and often shallow with some sites drying out completely in the dry season. This relief gradient may be important for the assemblage of different plant communities compared to other habitats. Plants tolerant of shorter hydroperiods and those that grow fast to avoid shade-out might be well-suited for near-pond habitats. The pond itself often had emergent plants in shallow edges of the pond adjacent to the near-pond transition and occasionally had groups of Nuphar advena (spadderdock) and Nymphoides aquatica (banana lily). Floating aquatic macrophytes generally occur in deeper, open water habitats throughout the Everglades because of lack of competition from emergent vegetation (Busch et al. 1998; Daoust and Childers 1999).

In the wet season, plant community composition varied with an interaction of floc TP and slough. It appears that the difference is associated with plants (e.g., Typha domingensis, Cladium jamacense, spadderdock) seen mainly in Shark River Slough compared to Taylor Slough. In general, vascular plants are generally slow to respond to enrichment (Noe et al. 2002), but some species of plants are strongly associated with Penrichment. T. domingensis (cattail) was only detected at three sites (LJB, CATB, and WG16) where it had largely monotypic stands in pond and near-pond vegetation. Palmer and Mazzotti (2004) characterized alligator ponds, finding that cattail-dominated ponds had deeper basin depths than other ponds. In wetlands, it is thought that cattails are an indicator of nutrient enrichment (Vaithiyanathan and Richardson 1999). Interestingly, the three sites with cattails had some of the highest water column TP values, though had intermediate floc TP values. Overall, small-scale disturbances from pond maintenance and biological activity created by alligators and associated biota likely increase 
topographic heterogeneity, alter soil characteristics and nutrient dynamics, and manipulate plant communities through predation and physical destruction. Like Palmer and Mazzotti (2004), we hypothesize that actions such as these are responsible for the marked differences in plant communities observed at alligator ponds compared to the surrounding marsh.

Many of the invertebrates collected in our funnel traps were relatively small. For instance, ostracods are one of the smallest animals by body size in our sampling, but they were also the most abundant. Mollusks were in low abundance as reported elsewhere (Ruehl and Trexler 2011) though funnel traps may not be the best sampling method. For instance, larger invertebrates like gastropods were present in our throw trap sampling but may not be adequately sampled by our modified funnel traps because of funnel size or lack of vertical migration (Turner and Trexler 1997). However, larger invertebrates may play important roles as predators of other benthic fauna. One major unknown in our study, along with many that use passive sampling methods, is quantifying the animal movement rates and capture efficiency of techniques across habitats. Future studies may employ multiple capture techniques to effectively compare benthic invertebrate diversity across habitats.

We found that amphipods were most abundant in the marsh, which are generally much larger than the other common taxa. In another study, amphipod abundance declined dramatically across a gradient of enrichment with abundance ten times higher in the unenriched marsh (McCormick et al. 2004). In addition, amphipods are tightly coupled with periphyton mats and may be sensitive to hydroperiod (Liston 2006), which might make the marsh habitat preferable. Ostracods, copepods, and aquatic mites were abundant 
in the pond compared to other habitats. Some studies indicate that assemblages of aquatic mites may be negatively correlated with wastewater pollution, though little is known about habitat association of aquatic mites in wetlands (see Goldschmidt 2016). Liston (2006) found that for both ostracods and copepods, the interaction of P availability and hydroperiod was associated with benthic floc infaunal crowding. The pond habitat certainly had a longer hydroperiod regime staying relatively deep year-round and the floc TP values were the highest in this habitat. At enriched sites, Rader and Richardson (1994) found that ostracods were 14 times more abundant than unenriched sites. In our study, mean CPUE per site was twice as high for ostracods in the pond compared to the marsh. Overall, floc TP did not predict benthic invertebrate composition in our study. In another study, benthic floc infauna community structure and density was best explained by hydroperiod but not P availability (Liston 2006). We did find that benthic invertebrate community composition of the marsh (lowest floc TP) and pond (highest floc TP) habitats were the most dissimilar with near-pond habitat (intermediate floc TP) sharing similarities with both.

Overall the near-pond habitat was the most diverse habitat between seasons for benthic invertebrates. It appears that emergent vegetation like sawgrass stands or cattails contain more diverse and greater abundance of benthic invertebrates and macroinvertebrates than spikerush marshes (Jordan 1996; Turner and Trexler 1997). Our near-pond was dominated by emergent macrophytes which might provide an abundance of food and habitat for invertebrates (Batzer and Wissinger 1996). We observed higher richness in the wet season compared to the dry season driven primarily by the extreme differences in the near-pond habitat. It is suspected that extremely dense stands with short 
hydroperiods may not be good habitat overall for aquatic invertebrates (Rader 1994). We observed several of our near-pond habitats completely dry out during our dry season sampling. The greater richness of benthic invertebrates in pond compared to near-pond habitats in the dry season may imply that some invertebrates may have moved into the pond from the near-pond to avoid desiccation. Alternatively, enhanced biological activity in the pond during the dry season may encourage dispersal from the nearby near-pond habitat. Benthic invertebrates living in habitats with unpredictable environmental conditions such as drydown likely have good dispersal abilities and flexible life histories (Williams 1996).

Across both sloughs in the wet season, aquatic consumer richness was on average 11 species lower in the pond than the near-pond and marsh. The pond appeared to be dominated by only a few species in comparatively large numbers. The two fish we did observe in abundance were Gambusia holbrooki (Eastern Mosquitofish) and Lucania goodei (Bluefin Killifish). The Eastern Mosquitofish is an excellent disperser and has strong response to both flooding and drying, which may have led to its impressive range expansion (Goss et al. 2014). Thus, it is not surprising that it was also abundant in the pond habitat. Our sampling methods only allowed us to capture relatively small fish. Larger fish like Florida Gar and Largemouth Bass were certainly present and were captured within pond and marsh habitats using electrofishing methods (J. Trexler, personal communication). These fish are piscivorous and their presence likely scares smaller fish into more structured habitats like the near-pond and marsh (Savino and Stein 1982) potentially explaining low sampled richness in the pond habitat. We also found that during the dry season, richness was greater in the marsh compared to the other two 
habitats. Near-pond habitats in the dry season were in some cases completely dry or low in depth and would not be good habitat for fishes and invertebrates. Pond habitats are thought to be a refuge for many aquatic fauna during seasonal drying (Kushlan and Kushlan 1980). Thus, we expected greater abundance and more diverse communities in the pond during drydown. Edge habitats often had stands of dense vegetation and woody structure which likely contain a majority of the small fish using structure to avoid predation. In fact, structure-heavy and complex littoral areas contain higher small fish densities and richness (Gratwicke and Speight 2005; Diehl 1992).

Palaemonetes paludosus (grass shrimp), Eastern Mosquitofish, and Bluefin Killifish were abundant across the study. This is not surprising given that grass shrimp and Eastern Mosquitofish are two of the most abundant animals across the freshwater Everglades (Brown et al. 2006). The marsh habitat had very high catch rates of grass shrimp. The grass shrimp feeds off of small invertebrates and consumes periphyton (Geddes and Trexler 2003). When grass shrimp are excluded, invertebrate taxa are more abundant in the near-pond than other habitats between seasons. Overall, near-pond and marsh community compositions were similar but pond aquatic consumer communities were dissimilar to both. For instance, explaining some of the differences between communities in the wet season, Pelocoris femoratus (creeping water bug) was abundant in the marsh, rare in the near-pond, and almost absent in the pond habitat. This species' distribution might be tied to water depth. In one study of invertebrate communities in the Okefenokee Swamp of Georgia, Pelocoris spp. were most abundant in wet prairie compared to cypress habitats (Kratzer and Batzer 2007). 
Total phosphorus in the floc did not explain differences in consumer communities. For instance, we would predict that herbivorous fish like Jordanella floridae (Flagfish) and Poecilia latipinna (Sailfin Molly) would be higher in habitats like near-pond and pond given nutrient enrichment found in the floc and potential increased primary production (Liston 2006). Sailfin Molly catches were higher in pond and nearpond habitats, but Flagfish were most abundant in the marsh. Another study, Rader and Richardson (1994), found that the richness and density of invertebrates and small fish overall were greater in enriched open water habitats than unenriched spikerush marshes. Specifically, amphipods, Eastern Mosquitofish, and the Heterandria formosa (Least Killifish) all had two to three times higher densities in enriched compared to unenriched sites (Rader and Richardson 1994). Interestingly, grass shrimp actually had the opposite trend with lower densities in enriched areas (Rader and Richardson 1994). We did observe higher catches of grass shrimp in the marsh and high catches of Eastern Mosquitofish in the pond which does correlate with floc TP findings.

\section{Conclusion}

Alligator-engineered ponds may be ecologically important by providing nutrient subsidies to an oligotrophic system, habitat heterogeneity to marshes, and refuges for other fauna during seasonal disturbances. We demonstrated differences in community structure across pond, near-pond, and marsh habitats. Our study also demonstrates that some alligator-engineered ponds are enriched relative to the surrounding marsh. However, not all ponds exhibited the same level of enrichment or trophic structure. For instance, we found seasonal and slough-level differences in community structure of 
ponds. We hypothesize that differences in local microtopography, alligator occupancy rates, and hydrological variables may impact the enrichment and community structure of alligator ponds. These habitats may have distinct food-web compartments and potentially different energy pathways. Oligotrophic marsh food webs in the Everglades have more energy in detrital pathways than in primary production with microbial communities dominated by heterotrophic bacteria and other saprophytes (DeAngelis et al. 1998). In areas where even minor P loading occurs, like in alligator ponds, patches may have enhanced primary production and thus more algal- rather than detrital-based food webs compared to the marsh (Gaiser et al. 2005; Heymans et al. 2002). Work presented in the following chapter will explicitly test the hypothesis that these engineered ponds have an associated difference in ecosystem function. Using fatty acid biomarkers, we will look at the origin of organic matter and the pathway of energy flow in these food webs as a function of habitat. In addition, future efforts to quantitatively scale up the effects of alligator-engineered heterogeneity in nutrients and habitats may help us understand the ecological importance of engineering at the landscape level.

Alligators are an ecological indicator for current Everglades restoration efforts (Mazzotti et al. 2009) and the typical performance measure of alligator abundance may lead to confounding conclusions of restoration impacts because of the feedback loop created by their role as an engineer. Restoration generally focuses on abiotic variables or vegetation assuming that animal populations and communities will recover and return in abundance to habitats. For instance, efforts to restore the Everglades have focused on recreating natural hydrological patterns by decompartmentalizing areas blocked by canals and levees (NASEM 2016). However, often not considered in restoration plans is the fact 
that animals play important parts in engineering habitats and influencing ecosystem processes. The abundance, distribution, and even behavior of alligators has been impacted by drainage and subsequently restoration (Mazzotti et al. 2009). Given the demonstrated effects of alligators as ecosystem engineers, successful restoration may also depend on the conservation and reestablishment of alligator-engineered habitats.

\section{Acknowledgements}

This work was funded by Everglades National Park Task Agreement P18AC01074 under the Master Cooperative Agreement P18AC01074. The project was also supported by the National Science Foundation through the Florida Coastal Everglades Long-Term Ecological Research program under Grant \#DEB-1237517. We are grateful to many field and lab volunteers that assisted with this project especially Peter Flood and Joel Trexler. We thank Katherine Strickland for providing help for figures and tables. BAS was supported by the University Graduate School and Department of Biological Sciences assistantships at Florida International University as well as an Everglades Foundation fellowship. Research and animal procedures were conducted under the auspices of protocol \#IACUC-18-067-CR01 from the Institutional Animal Care and Use Committee of the University of Florida and in accordance with scientific research permit \#EVER-2017-SCI-0060 authorized by Everglades National Park and scientific collector's permits \#S-18-06 and \#S-19-05 granted by Florida Fish and Wildlife Conservation Commission. 


\section{Literature Cited}

Batzer, D. P. and S. A. Wissinger. 1996. Ecology of insect communities in nontidal wetlands. Annual Review of Entomology 41:75-100.

Belicka, L. L., E. R. Sokol, M. J. Hoch, R. Jaffé, and J. C. Trexler. 2012. A molecular and stable isotopic approach to investigate algal and detrital energy pathways in a freshwater marsh. Wetlands 32:531-542.

Brakke, D. F. 1976. Modification of the Whiteside-Willimas pattern sampler. Journal of Fisheries Research Board of Canada 33:2861-2863.

Brandt, L. A., M. R. Campbell, and F. J. Mazzotti. 2010. Spatial distribution of alligator holes in the central Everglades. Southeastern Naturalist 9:487-496.

Brown, M. T., Cohen, M. J., Bardi, E., \& Ingwersen, W. W. (2006). Species diversity in the Florida Everglades, USA: A systems approach to calculating biodiversity. Aquatic Sciences, 68(3), 254-277.

Busch, D. E., Loftus, W. F., \& Bass, O. L. 1998. Long-term hydrologic effects on marsh plant community structure in the southern Everglades. Wetlands, 18(2), 230-241.

Campbell, M. R., and F. J. Mazzotti. 2004. Characterization of natural and artificial alligator holes. Southeastern Naturalist 3:583-594.

Childers, D. L., Doren, R. F., Jones, R., Noe, G. B., Rugge, M., \& Scinto, L. J. 2003. Decadal change in vegetation and soil phosphorus pattern across the Everglades landscape. Journal of Environmental Quality, 32(1), 344-362.

Clarke, K. R., and R. M. Warwick. 2001. Change in Marine Communities: An Approach to Statistical Analysis and Interpretation. Prime-E Ltd, Plymouth, U.K

Daoust, R. J., and D. L. Childers. 1999. Controls on emergent macrophyte composition, abundance, and productivity in freshwater everglades wetland communities. Wetlands 19:262-275.

DeAngelis, D. L., L. J. Gross, M. A. Huston, W. F. Wolff, D. M. Fleming, E. J. Comiskey, and S. M. Sylvester. 1998. Landscape modeling for everglades ecosystem restoration. Ecosystems 1:64-75.

Delany, M.F. and C. Abercrombie. 1986. American alligator food habits in northcentral Florida. Journal of Wildlife Management 50:348-353.

Diehl, S. (1992). Fish predation and benthic community structure: the role of omnivory and habitat complexity. Ecology, 73(5), 1646-1661. 
Dyer, L. A., \& Letourneau, D. (2003). Top-down and bottom-up diversity cascades in detrital vs. living food webs. Ecology Letters, 6(1), 60-68.

Elser, J. J., and J. Urabe. 1999. The stoichiometry of consumer-driven nutrient recycling: theory, observations, and consequences. Ecology 80:735-751.

Estes, J. A., J. Terborgh, J. S. Brashares, M. E. Power, J. Berger, W. J. Bond, S. R. Carpenter, T. E. Essington, R. D. Holt, J. B. C. Jackson, R. J. Marquis, L. Oksanen, T. Oksanen, R. T. Paine, E. K. Pikitch, W. J. Ripple, S. A. Sandin, M. Scheffer, T. W. Schoener, J. B. Shurin, A. R. E. Sinclair, M. E. Soulé, R. Virtanen, and D. A. Wardle. 2011. Trophic downgrading of planet Earth. Science 333:301-306.

Flecker, A. S., B. W. Taylor, E. S. Bernhardt, J. M. Hood, W. K. Cornwell, S. R. Cassatt, M. J. Vanni, and N. S. Altman. 2002. Interactions between herbivorous fishes and limiting nutrients in a tropical stream ecosystem. Ecology 83:1831-1844.

Fujita, M., \& Koike, F. (2007). Birds transport nutrients to fragmented forests in an urban landscape. Ecological Applications, 17(3), 648-654.

Hairston, N. G., Smith, F. E., \& Slobodkin, L. B. (1960). Community structure, population control, and competition. The American Naturalist, 94(879), 421-425.

Gaiser, E. (2009). Periphyton as an indicator of restoration in the Florida Everglades. Ecological Indicators, 9(6), S37-S45.

Gaiser, E. E., L. J. Scinto, J. H. Richards, K. Jayachandran, D. L. Childers, J. D. Trexler, And R. D. Jones. 2004. Phosphorus in periphyton mats provides best metric for detecting low-level P enrichment in an oligotrophic wetland. Water Res. 38: 507516.

Gaiser, E. E., J. C. Trexler, J. H. Richards, D. L. Childers, D. Lee, A. L. Edwards, L. J. Scinto, K. Jayachandran, G. B. Noe, and R. D. Jones. 2005. Cascading ecological effects of low-level phosphorus enrichment in the Florida everglades. Journal of Environmental Quality 34:717-23.

Gaiser, E. E., Childers, D. L., Jones, R. D., Richards, J. H., Scinto, L. J., \& Trexler, J. C. (2006). Periphyton responses to eutrophication in the Florida Everglades: Crosssystem patterns of structural and compositional change. Limnology and Oceanography, 51(1 part 2), 617-630.

Gaiser, E. E., J. C. Trexler, and P. R. Wetzel. 2012. The Florida Everglades in Batzer, D. P., and A. H. Baldwin. eds., Wetland Habitats of North America: Ecology and Conservation Concerns. Berkeley: University of California Press. 
Geddes, P., \& Trexler, J. C. (2003). Uncoupling of omnivore-mediated positive and negative effects on periphyton mats. Oecologia, 136(4), 585-595.

Goldschmidt, T. (2016). Water mites (Acari, Hydrachnidia): powerful but widely neglected bioindicators-a review. Neotropical Biodiversity, 2(1), 12-25.

Goss, C. W., Loftus, W. F., \& Trexler, J. C. (2014). Seasonal fish dispersal in ephemeral wetlands of the Florida Everglades. Wetlands, 34(1), 147-157.

Gotelli, N.J. and Colwell, R.K., 2011. Estimating species richness. Biological diversity: frontiers in measurement and assessment, 12, pp.39-54.

Gratwicke, B., \& Speight, M. R. (2005). The relationship between fish species richness, abundance and habitat complexity in a range of shallow tropical marine habitats. Journal of fish biology, 66(3), 650-667.

Heymans, J. J., R. E. Ulanowicz, and C. Bondavalli. 2002. Network analysis of the South Florida Everglades graminoid marches and comparison with nearby cypress ecosystems. Ecological Modelling 149:5-23.

Hudson, J. J., W. D. Taylor, And D. W. Schindler. 2000. Phosphate concentrations in lakes. Nature 406: 54-55.

Jones, C. G., J. H. Lawton, and M. Shachak. 1997. Positive and negative effects of organisms as physical ecosystem engineers. Ecology 78:1946-1957.

Jordan, C. F. (1996). Spatial ecology of decapods and fishes in a northern Everglades wetland mosaic (Doctoral dissertation, University of Florida).

Jordan, F., Coyne, S., and Trexler, J. C. (1997). Sampling fishes in vegetated habitats: effects of habitat structure on sampling characteristics of the $1-\mathrm{m}^{2}$ throw trap. Transactions of the American Fisheries Society, 126(6), 1012-1020.

Komarek, J., D. Sirova, J. Komarkova, and L. Rejmankova. 2015. Structure and function of cyanobacterial mats in wetlands of Belize in Entry, J.A., Gottlieb, A.D., Jayachandran, K. and Ogram, A. eds., Microbiology of the Everglades Ecosystem. CRC Press.

Kotun, K., \& Renshaw, A. (2014). Taylor Slough hydrology. Wetlands, 34(1), 9-22.

Kratzer, E. B., \& Batzer, D. P. (2007). Spatial and temporal variation in aquatic macroinvertebrates in the Okefenokee Swamp, Georgia, USA. Wetlands, 27(1), 127140. 
Kushlan, J. A. 1974. Observations on the role of the American alligator in the Southern Flordia wetlands. Copeia 4:993-996.

Kushlan, J. A., and B. Hunt. 1979. Limnology of an alligator pond in South Florida. Florida Scientist 42:66-84.

Kushlan, J. A., and M. S. Kushlan. 1980. Everglades alligator nests: nesting sites for marsh reptiles. Copeia:1930-1932.

Liston, S. E. (2006). Interactions between nutrient availability and hydroperiod shape macroinvertebrate communities in Florida Everglades marshes. Hydrobiologia, 569(1), 343-357.

Lynam, C. P., Llope, M., Möllmann, C., Helaouët, P., Bayliss-Brown, G. A., \& Stenseth, N. C. (2017). Interaction between top-down and bottom-up control in marine food webs. Proceedings of the National Academy of Sciences, 114(8), 1952-1957.

Matson, P. A., \& Hunter, M. D. (1992). Special feature: The relative contributions to topdown and bottom-up forces in population and community ecology. Ecology, 73(3), 723-723.

Mazzotti, F. J., G. R. Best, L. A. Brandt, M. S. Cherkiss, B. M. Jeffery, and K. G. Rice. 2009. Alligators and crocodiles as indicators for restoration of Everglades ecosystems. Ecological Indicators 9:S137-S149.

McClain, M. E., E. W. Boyer, C. L. Dent, S. E. Gergel, N. B. Grimm, P. M. Groffman, S. C. Hart, J. W. Harvey, C. A. Johnston, E. Mayorga, W. H. McDowell, and G. Pinay. 2003. Biogeochemical hot spots and hot moments at the interface of terrestrial and aquatic ecosystems. Ecosystems 6:301-312.

McCormick, P. V, S. Newman, S. Miao, D. E. Gawlik, D. Marley, K. R. Reddy, and T. D. Fontaine. 2002. Effects of anthropogenic phosphorus inputs on the Everglades. Pages 83-126 in J. W. Porter and K. G. Porter, editors. The Everglades, Florida Bay, and Coral Reefs of the Florida Keys: an Ecosystem Sourcebook. CRC, Boca Raton, FL.

McCormick, P. V, and R. J. Stevenson. 1991. Grazer control of nutrient availability in the periphyton. Oecologia 86:287-291.

McCormick, P. V. 1994. Evaluating the multiple mechanisms underlying herbivore-algal interactions in streams. Hydrobiologia 291:47-59.

McCormick, P. V., Shuford, R. B., \& Rawlik, P. S. (2004). Changes in macroinvertebrate community structure and function along a phosphorus gradient in the Florida Everglades. Hydrobiologia, 529(1-3), 113-132. 
McCormick, P. V., \& Stevenson, R. J. (1998). Periphyton as a tool for ecological assessment and management in the Florida Everglades. Journal of Phycology, 34(5), 726-733.

Meserve, P. L., Kelt, D. A., Milstead, W. B., \& Gutiérrez, J. R. (2003). Thirteen years of shifting top-down and bottom-up control. BioScience, 53(7), 633-646.

Naiman, R. J., G. Pinay, C. A. Johnston, and J. Pastor. 1994. Beaver influences on the long-term biogeochemical characteristics of boreal forest drainage networks. Ecology 75:905-921.

Naiman, R. J., and K. H. Rogers. 1997. Large animals and in river corridors: implications for river management. BioScience 47:521-529.

National Academies of Sciences, Engineering, and Medicine (NASEM). 2016. Progress Toward Restoring the Everglades: The Sixth Biennial Review - 2016. Washington, DC: The National Academies Press. Doi: 10.17226/23672.

Neto, R. R., Mead, R. N., Louda, J. W., \& Jaffé, R. (2006). Organic biogeochemistry of detrital flocculent material (floc) in a subtropical, coastal wetland. Biogeochemistry, 77(3), 283-304.

Nifong, J. C., and B. R. Silliman. 2013. Impacts of a large-bodied, apex predator (Alligator mississippiensis Daudin 1801) on salt marsh food webs. Journal of Experimental Marine Biology and Ecology 440:185-191.

Noe, G. B., D. L. Childers, L. J. Scinto, A. L. Edwards, E. Gaiser, D. Lee, J. Trexler, and R. D. Jones. 2002. Short-term changes in phosphorus storage in an oligotrophic Everglades wetland ecosystem receiving experimental nutrient enrichment. Biogeochemistry 59:239-267.

Noe, G. B., Scinto, L. J., Taylor, J., Childers, D. L., \& Jones, R. D. (2003). Phosphorus cycling and partitioning in an oligotrophic Everglades wetland ecosystem: a radioisotope tracing study. Freshwater Biology, 48(11), 1993-2008.

Obaza, A., D. L. DeAngelis, and J. C. Trexler. 2011. Using data from an encounter sampler to model fish dispersal. Journal of Fish Biology 78:495-513.

Oksanen, L., Fretwell, S. D., Arruda, J., \& Niemela, P. (1981). Exploitation ecosystems in gradients of primary productivity. The American Naturalist, 118(2), 240-261.

Palmer, M. L., and F. J. Mazzotti. 2004. Structure of everglades alligator holes. Wetlands 24:115-122. 
Polis, G. A. (1999). Why are parts of the world green? Multiple factors control productivity and the distribution of biomass. Oikos, 3-15.

Polis, G. A., W. B. Anderson, and R. D. Holt. 1997. Toward an integration of landscape and food web ecology: the dynamics of spatially subsidized food webs. Annual Review of Ecology and Systematics 28:289-316.

Pringle, C. M., G. A. Blake, A. P. Covich, K. M. Buzby, and A. Finley. 1993. Effects of omnivorous shrimp in a montane tropical stream: sediment removal, disturbance of sessile invertebrates and enhancement of understory algal biomass. Oecologia 93:111.

Rader, R.B. 1994. Macroinvertebrates of the northern Everglades: species composition and trophic structure. Florida Scientist 57:22-33.

Rader, R.B., Richardson, C.J. Response of macroinvertebrates and small fish to nutrient enrichment in the northern Everglades. Wetlands 14, 134-146 (1994). https://doi.org/10.1007/BF03160629.

Roman J and McCarthy JJ. 2010. The whale pump: marine mammals enhance primary productivity in a coastal basin. PLoS ONE 5: e13255.

Rosenblatt, A. E., and M. R. Heithaus. 2011. Does variation in movement tactics and trophic interactions among American alligators create habitat linkages? The Journal of Animal Ecology 80:786-798.

Rosenblatt, A.E., J.C. Nifong, M.R. Heithaus, F.J. Mazzotti, M.S. Cherkiss, B.M. Jeffery, R.M. Elsey, R.A. Decker, B.R. Silliman, L.J. Guillette, R.H. Lowers, J.C. Larson. 2015. Factors affecting individual foraging specialization and diet stability across the range of a large "generalist" apex predator. Oecologia 178:5-16.

Ruehl, C. B., \& Trexler, J. C. (2011). Comparison of snail density, standing stock, and body size between Caribbean karst wetlands and other freshwater ecosystems. Hydrobiologia, 665(1), 1-13.

Sanders, D., C. G. Jones, E. Thébault, T. J. Bouma, T. van der Heide, J. van Belzen, and S. Barot. 2014. Integrating ecosystem engineering and food webs. Oikos 123:513524.

Sanders, D., \& van Veen, F. F. (2011). Ecosystem engineering and predation: the multitrophic impact of two ant species. Journal of Animal Ecology, 80(3), 569-576.

Savino, J.F. and R.A. Stein. 1982. Predator-prey interaction between largemouth bass and bluegills as influenced by simulated, submersed vegetation. Transactions of the American Fisheries Society 111:255-266. 
Schmitz, O. J., D. Hawlena, and G. C. Trussell. 2010. Predator control of ecosystem nutrient dynamics. Ecology Letters 13:1199-1209.

Schmitz, O. J., V. Krivan, and O. Ovadia. 2004. Trophic cascades: The primacy of traitmediated indirect interactions. Ecology Letters 7:153-163.

Spivak, A. C., Canuel, E. A., Duffy, J. E., \& Richardson, J. P. (2007). Top-down and bottom-up controls on sediment organic matter composition in an experimental seagrass ecosystem. Limnology and Oceanography, 52(6), 2595-2607.

Subalusky, A. L., L. A. Fitzgerald, and L. L. Smith. 2009. Ontogenetic niche shifts in the American alligator establish functional connectivity between aquatic systems. Biological Conservation 142:1507-1514.

Turner, A. M., \& Trexler, J. C. (1997). Sampling aquatic invertebrates from marshes: evaluating the options. Journal of the North American Benthological Society, 16(3), 694-709.

Turner, A. M., Trexler, J. C., Jordan, C. F., Slack, S. J., Geddes, P., Chick, J. H., \& Loftus, W. F. (1999). Targeting ecosystem features for conservation: standing crops in the Florida Everglades. Conservation Biology, 13(4), 898-911.

Vaithiyanathan, P. and C. J. Richardson. 1999. Macrophyte species changes in the Everglades: Examination along a eutrophication gradient. Journal of Environmental Quality 28:1347-1358.

Vanni, M. J. 2002. Nutrient cycling by animals in freshwater ecosystems. Annual Review of Ecology and Systematics 33:341-370.

Whiteside, M. C. and J. B. Williams. 1975. A new sampling technique for aquatic ecologists. Verhandlungen der Internationale Vereinigung für Theoretische und Angewandte Limnolgie 19:1534-1539.

Williams, D. D., 1996. Environmental constraints in temporary fresh waters and their consequences for the insect fauna. Journal of the North American Benthological Society 15:634-650.

Williams, A. J., and J. C. Trexler. 2006. A preliminary analysis of the correlation of foodweb characteristics with hydrology and nutrient gradients in the southern Everglades. Hydrobiologia 569:493-504.

Wilkinson, D. M., \& Sherratt, T. N. (2016). Why is the world green? The interactions of top-down and bottom-up processes in terrestrial vegetation ecology. Plant Ecology \& Diversity, 9(2), 127-140. 
Wojdak, J. M. (2005). Relative strength of top-down, bottom-up, and consumer species richness effects on pond ecosystems. Ecological Monographs, 75(4), 489-504.

Wright, J. P., and C. G. Jones. 2006. The concept of organisms as ecosystem engineers ten years on: progress, limitations, and challenges. BioScience 56:203.

Wright, J. P., C. G. Jones, and A. S. Flecker. 2002. An ecosystem enginer, the beaver, increases species richness at the landscape scale. Oecologia 132:96-101. 
Table 1: Repeated-measures analysis of variance of water-column total phosphorus. Sampling was performed in marsh, near-pond, and pond habitats in ten sites in Taylor Slough and Shark River Slough in the 2018 wet and 2019 dry seasons. Seasonal models were run separately because we were unable to collect dry season near-pond samples.

\begin{tabular}{|c|c|c|c|c|c|c|c|}
\hline Model & Error & Source & df & SSq & MSq & $\mathbf{F}$ & $p$ \\
\hline \multirow{5}{*}{ Wet Season } & \multirow{2}{*}{ Site } & Slough & 1 & 105.50 & 105.54 & 3.65 & 0.09 \\
\hline & & Residuals & 8 & 231.60 & 28.95 & & \\
\hline & \multirow{3}{*}{ Site*Habitat } & Habitat & 2 & 105.90 & 52.93 & 1.47 & 0.26 \\
\hline & & Slough*Habitat & 2 & 30.00 & 14.99 & 0.42 & 0.67 \\
\hline & & Residuals & 16 & 578.00 & 36.13 & & \\
\hline \multirow{5}{*}{ Dry Season } & \multirow{2}{*}{ Site } & Slough & 1 & 4.07 & 4.07 & 0.46 & 0.41 \\
\hline & & Residuals & 7 & 37.64 & 5.38 & & \\
\hline & \multirow{3}{*}{ Site*Habitat } & Habitat & 1 & 5.43 & 5.43 & 1.31 & 0.29 \\
\hline & & Slough*Habitat & 1 & 1.02 & 10.02 & 2.42 & 0.16 \\
\hline & & Residuals & 7 & 28.97 & 4.14 & & \\
\hline
\end{tabular}


Table 2: Repeated-measures analysis of variance of floc total phosphorus. Sampling was performed in marsh, near-pond, and pond habitats at ten sites in Taylor Slough and Shark River Slough in the 2018 wet season.

\begin{tabular}{|l|l|l|l|l|l|l|}
\hline Error & Source & df & SSq & MSq & F & $\boldsymbol{p}$ \\
\hline \multirow{2}{*}{ Site } & Slough & 1 & 39.60 & 39.63 & 0.60 & 0.46 \\
\cline { 2 - 7 } & Residuals & 8 & 532.20 & 66.52 & & \\
\hline \multirow{3}{*}{ Site*Habitata } & Habitat & 2 & 1363.40 & 681.70 & 12.84 & $<\mathbf{0 . 0 1}$ \\
\cline { 2 - 7 } & Slough*Habitat & 2 & 19.80 & 9.90 & 0.19 & 0.83 \\
\cline { 2 - 7 } & Residuals & 16 & 849.20 & 53.10 & & \\
\hline
\end{tabular}


Table 3: Estimated marginal least-squares means of floc total phosphorus compared among habitats. Sampling was performed in marsh, near-pond, and pond habitats at ten sites in Taylor Slough and Shark River Slough in the 2018 wet season.

\begin{tabular}{|l|l|l|l|l|}
\hline Contrast & Estimate \pm SE & df & t ratio & $\boldsymbol{p}$ \\
\hline marsh - near-pond & $-8.3 \pm 3.1$ & 18 & -2.7 & $\mathbf{0 . 0 4}$ \\
\hline marsh - pond & $-16.5 \pm 3.1$ & 18 & -5.3 & $<\mathbf{0 . 0 1}$ \\
\hline near-pond - pond & $-8.2 \pm 3.1$ & 18 & -2.6 & $\mathbf{0 . 0 4}$ \\
\hline
\end{tabular}


Table 4: Presence of aquatic plants sampled in marsh, near-pond, and pond habitats at ten sites in Taylor Slough and Shark River Slough in the 2018 wet and 2019 dry seasons. Presence is expressed as the proportion of visits to each habitat at ten sites across two seasons.

\begin{tabular}{|c|c|c|c|c|}
\hline Common Name & Scientific Name & $\begin{array}{c}\text { Marsh } \\
\text { Presence }\end{array}$ & $\begin{array}{c}\text { Near-pond } \\
\text { Presence }\end{array}$ & $\begin{array}{c}\text { Pond } \\
\text { Presence }\end{array}$ \\
\hline Sawgrass & Cladium jamaicense & 0.40 & 0.35 & 0.40 \\
\hline Gulfcoast spikerush & Eleocharis cellulosa & 1.00 & 0.55 & 0.55 \\
\hline Slim spikerush & Eleocharis elongata & 0.15 & 0.00 & 0.00 \\
\hline Green arrow arum & Peltandra virginica & 0.00 & 0.40 & 0.45 \\
\hline Eastern purple bladderwort & Utricularia purpurea & 0.50 & 0.05 & 0.30 \\
\hline Leafy bladderwort & Utricularia foliosa & 0.80 & 0.15 & 0.40 \\
\hline Duck potato & Sagitarria lancifolia & 0.40 & 0.75 & 0.45 \\
\hline Pickerelweed & Pontedaria cordata & 0.00 & 0.65 & 0.85 \\
\hline Spider lily & Hymenocallis latifolia & 0.05 & 0.20 & 0.05 \\
\hline Tracy's beaksedge & Rhycospora tracyi & 0.20 & 0.00 & 0.05 \\
\hline Maidencane & Panicum hemitonum & 0.50 & 0.50 & 0.40 \\
\hline Lemon bacopa & Bacopa carolinia & 0.25 & 0.05 & 0.00 \\
\hline Pondweed & Potamogeton illinoensis & 0.10 & 0.10 & 0.10 \\
\hline Red ludwigia & Ludwigia repens & 0.00 & 0.05 & 0.05 \\
\hline Banana lily & Nymphoides aquatica & 0.30 & 0.00 & 0.00 \\
\hline Southern cattail & Tyhpa domingensis & 0.00 & 0.10 & 0.25 \\
\hline American white waterlily & Nymphaea odorata & 0.10 & 0.00 & 0.10 \\
\hline Spatterdock & Nuphar advena & 0.00 & 0.00 & 0.25 \\
\hline Egyptian paspaladium & Paspaladium geminatum & 0.35 & 0.00 & 0.15 \\
\hline Climbing hempvine & Mikania scandens & 0.00 & 0.00 & 0.05 \\
\hline Southern cutgrass & Leersia hexandra & 0.00 & 0.00 & 0.05 \\
\hline
\end{tabular}


Table 5: Repeated-measures analysis of variance of richness of plant communities. Sampling was performed in marsh, near-pond, and pond habitats at ten sites in Taylor Slough and Shark River Slough in the 2018 wet and 2019 dry seasons.

\begin{tabular}{|l|l|l|l|l|l|l|}
\hline Error & Source & df & SSq & MSq & F & $\boldsymbol{p}$ \\
\hline \multirow{2}{*}{ Site } & Slough & 1 & 1.35 & 1.35 & 0.19 & 0.67 \\
\cline { 2 - 8 } & Residuals & 8 & 56.33 & 7.04 & & \\
\hline \multirow{3}{*}{ Site*Season } & Season & 1 & 0.15 & 0.15 & 0.05 & 0.84 \\
\cline { 2 - 8 } & Slough*Season & 1 & 3.75 & 3.75 & 1.16 & 0.31 \\
\cline { 2 - 8 } & Residuals & 8 & 25.93 & 3.24 & & \\
\hline \multirow{3}{*}{ Site*Habitat } & Habitat & 2 & 15.63 & 7.82 & 2.78 & 0.09 \\
\cline { 2 - 8 } & Slough*Habitat & 2 & 9.30 & 4.65 & 1.65 & 0.22 \\
\cline { 2 - 7 } & Residuals & 16 & 45.07 & 2.82 & & \\
\hline \multirow{3}{*}{ Site*Season*Habitat } & Season*Habitat & 2 & 0.70 & 0.35 & 0.15 & 0.86 \\
\cline { 2 - 8 } & Slough*Season*Habitat & 2 & 1.30 & 0.65 & 0.28 & 0.76 \\
\cline { 2 - 7 } & Residuals & 16 & 36.67 & 2.29 & & \\
\hline
\end{tabular}


Table 6: Permutational multivariate analysis of variance results from Morisita-Horn dissimilarity matrix of plant communities. Sampling was performed in marsh, near-pond, and pond habitats at ten sites in Taylor Slough and Shark River Slough in the 2018 wet and 2019 dry seasons.

\begin{tabular}{|l|l|l|l|l|l|l|}
\hline Dataset & Source & $\mathbf{d f}$ & $\mathbf{S S}$ & $\mathbf{R}^{\mathbf{2}}$ & $\mathbf{F}$ & $\boldsymbol{p}$ \\
\hline \multirow{5}{*}{ All Data } & Slough & 1 & 1.67 & 0.13 & 10.88 & $<\mathbf{0 . 0 1}$ \\
\cline { 2 - 7 } & Season & 1 & 0.05 & 0.00 & 0.35 & 0.83 \\
\cline { 2 - 7 } & Habitat & 2 & 2.95 & 0.22 & 9.64 & $<\mathbf{0 . 0 1}$ \\
\cline { 2 - 7 } & Slough*Season & 1 & 0.09 & 0.01 & 0.60 & 0.65 \\
\cline { 2 - 7 } & Slough*Habitat & 2 & 0.75 & 0.06 & 2.45 & $\mathbf{0 . 0 2}$ \\
\cline { 2 - 7 } & Season*Habitat & 2 & 0.18 & 0.01 & 0.58 & 0.79 \\
\cline { 2 - 7 } & Slough*Season*Habitat & 2 & 0.14 & 0.01 & 0.45 & 0.86 \\
\cline { 2 - 7 } & Residual & 48 & 7.33 & 0.56 & & \\
\cline { 2 - 7 } & Total & 59 & 13.15 & 1.00 & & \\
\hline \hline \multirow{5}{*}{ Wet Seasly } & Slough & 1 & 1.16 & 0.19 & 9.34 & $<\mathbf{0 . 0 1}$ \\
\cline { 2 - 7 } & Habitat & 2 & 1.36 & 0.22 & 5.48 & $<\mathbf{0 . 0 1}$ \\
\cline { 2 - 7 } & TP & 1 & 0.09 & 0.01 & 0.70 & 0.58 \\
\cline { 2 - 7 } & Slough*Habitat & 2 & 0.11 & 0.02 & 0.46 & 0.84 \\
\cline { 2 - 5 } & Slough*TP & 1 & 0.57 & 0.09 & 4.57 & $<\mathbf{0 . 0 1}$ \\
\cline { 2 - 7 } & Habitat*TP & 2 & 0.31 & 0.05 & 1.25 & 0.31 \\
\cline { 2 - 6 } & Slough*Habitat*TP & 2 & 0.40 & 0.06 & 1.60 & 0.15 \\
\cline { 2 - 7 } & Residual & 18 & 2.24 & 0.36 & & \\
\cline { 2 - 6 } & Total & 29 & 6.23 & 1.00 & & \\
\hline
\end{tabular}


Table 7: Relative abundance of benthic invertebrates sampled in marsh, near-pond, and pond habitats at ten sites in Taylor Slough and Shark River Slough in the 2018 wet and 2019 dry seasons.

\begin{tabular}{|l|l|l|}
\hline Group & Total & Percent \\
\hline Ostracoda & 3912 & 39.2 \\
\hline Copepoda & 2307 & 23.1 \\
\hline Trombidiformes & 1056 & 10.6 \\
\hline Cladocera & 1041 & 10.4 \\
\hline Amphipoda & 849 & 8.5 \\
\hline Diptera & 487 & 4.9 \\
\hline Ephemeroptera & 180 & 1.8 \\
\hline Mollusca & 55 & 0.6 \\
\hline Nematoda & 28 & 0.3 \\
\hline Odonata & 23 & 0.2 \\
\hline Hemiptera & 21 & 0.2 \\
\hline Platyhelminthes & 12 & 0.1 \\
\hline Decapod & 7 & $<0.1$ \\
\hline Arguloida & 1 & $<0.1$ \\
\hline Coleoa & 1 & $<0.1$ \\
\hline Mysida & 1 & $<0.1$ \\
\hline
\end{tabular}


Table 8: Repeated-measures analysis of variance of richness of benthic invertebrate communities. Funnel trap sampling was performed in marsh, near-pond, and pond habitats at ten sites in Taylor Slough and Shark River Slough in the 2018 wet and 2019 dry seasons.

\begin{tabular}{|l|l|l|l|l|l|l|}
\hline Error & Source & df & SSq & MSq & F & $\boldsymbol{p}$ \\
\hline \multirow{2}{*}{ Site } & Slough & 1 & 16.02 & 16.02 & 1.23 & 0.30 \\
\cline { 2 - 7 } & Residuals & 8 & 104.33 & 13.04 & & \\
\hline \multirow{3}{*}{ Site*Season } & Season & 1 & 62.02 & 62.02 & 11.91 & $<\mathbf{0 . 0 1}$ \\
\cline { 2 - 7 } & Slough*Season & 1 & 0.82 & 0.82 & 0.16 & 0.70 \\
\cline { 2 - 7 } & Residuals & 8 & 41.67 & 5.21 & & \\
\hline \multirow{3}{*}{ Site*Habitat } & Habitat & 2 & 50.53 & 25.27 & 2.25 & 0.14 \\
\cline { 2 - 7 } & Slough*Habitat & 2 & 40.93 & 20.47 & 1.82 & 0.19 \\
\cline { 2 - 7 } & Residuals & 16 & 179.87 & 11.24 & & \\
\hline \multirow{3}{*}{ Site*Season*Habitatatat } & Season*Habitat & 2 & 97.73 & 48.87 & 7.63 & $<\mathbf{0 . 0 1}$ \\
\cline { 2 - 7 } & Slough*Season*Habitat & 2 & 9.73 & 4.87 & 0.76 & 0.48 \\
\cline { 2 - 7 } & Residuals & 16 & 102.53 & 6.41 & & \\
\hline
\end{tabular}


Table 9: Estimated marginal least-squares means of richness of benthic invertebrate community for the interaction of season and habitat. Funnel trap sampling was performed in marsh, near-pond, and pond habitats at ten sites in Taylor Slough and Shark River Slough in the 2018 wet and 2019 dry seasons.

\begin{tabular}{|l|l|l|l|l|}
\hline Contrast & Estimate \pm SE & df & t ratio & $\boldsymbol{p}$ \\
\hline wet, marsh - dry, marsh & $2.5 \pm 1.1$ & 26.6 & 2.3 & 0.22 \\
\hline wet, marsh - wet, near-pond & $1.0 \pm 1.4$ & 32.5 & 0.7 & 0.98 \\
\hline wet, marsh - dry, near-pond & $5.9 \pm 1.3$ & 31.6 & 4.5 & $<\mathbf{0 . 0 1}$ \\
\hline wet, marsh - wet, pond & $2.6 \pm 1.4$ & 32.5 & 1.9 & 0.41 \\
\hline wet, marsh - dry, pond & $1.3 \pm 1.3$ & 31.6 & 1.0 & 0.92 \\
\hline dry, marsh - wet, near-pond & $-1.5 \pm 1.3$ & 31.6 & -1.1 & 0.86 \\
\hline dry, marsh - dry, near-pond & $3.4 \pm 1.4$ & 32.5 & 2.5 & 0.15 \\
\hline dry, marsh - wet, pond & $0.1 \pm 1.3$ & 31.6 & 0.1 & 1.00 \\
\hline dry, marsh - dry, pond & $-1.2 \pm 1.4$ & 32.5 & -0.9 & 0.95 \\
\hline wet, near-pond - dry, near-pond & $4.9 \pm 1.1$ & 26.6 & 4.6 & $<\mathbf{0 . 0 1}$ \\
\hline wet, near-pond - wet, pond & $1.6 \pm 1.4$ & 32.5 & 1.2 & 0.84 \\
\hline wet, near-pond - dry, pond & $0.3 \pm 1.3$ & 31.6 & 0.2 & 1.00 \\
\hline dry, near-pond - wet, pond & $-3.3 \pm 1.3$ & 31.6 & -2.5 & 0.16 \\
\hline dry, near-pond - dry, pond & $-4.6 \pm 1.4$ & 32.5 & -3.4 & $\mathbf{0 . 0 2}$ \\
\hline wet, pond - dry, pond & $-1.3 \pm 1.1$ & 26.6 & -1.2 & 0.83 \\
\hline
\end{tabular}


Table 10: Permutational multivariate analysis of variance results from Morisita-Horn dissimilarity matrix of benthic invertebrate communities. Funnel trap sampling was performed in marsh, near-pond, and pond habitats at ten sites in Taylor Slough and Shark River Slough in the 2018 wet and 2019 dry seasons.

\begin{tabular}{|l|l|l|l|l|l|l|}
\hline Dataset & Source & df & SS & $\mathbf{R}^{2}$ & $\mathbf{F}$ & $\boldsymbol{p}$ \\
\hline \multirow{5}{*}{ All Data } & Slough & 1 & 0.46 & 0.07 & 4.62 & $<\mathbf{0 . 0 1}$ \\
\cline { 2 - 7 } & Season & 1 & 0.34 & 0.05 & 3.40 & $\mathbf{0 . 0 3}$ \\
\cline { 2 - 7 } & Habitat & 2 & 1.41 & 0.21 & 7.04 & $<\mathbf{0 . 0 1}$ \\
\cline { 2 - 7 } & Slough*Season & 1 & 0.13 & 0.02 & 1.32 & 0.26 \\
\cline { 2 - 7 } & Slough*Habitat & 2 & 0.28 & 0.04 & 1.42 & 0.23 \\
\cline { 2 - 7 } & Season*Habitat & 2 & 0.21 & 0.03 & 1.03 & 0.40 \\
\cline { 2 - 7 } & Slough*Season*Habitat & 2 & 0.26 & 0.04 & 1.32 & 0.27 \\
\cline { 2 - 7 } & Residual & 37 & 3.71 & 0.54 & & \\
\cline { 2 - 7 } & Total & 48 & 6.81 & 1.00 & & \\
\hline \hline \multirow{5}{*}{ Wet Seasoly } & Slough & 1 & 0.14 & 0.05 & 1.73 & 0.21 \\
\cline { 2 - 7 } & Habitat & 2 & 0.56 & 0.21 & 5.50 & $\mathbf{0 . 0 2}$ \\
\cline { 2 - 7 } & TP & 1 & 0.24 & 0.09 & 3.04 & 0.07 \\
\cline { 2 - 7 } & Slough*Habitat & 2 & 0.15 & 0.06 & 0.96 & 0.44 \\
\cline { 2 - 5 } & Slough*TP & 1 & 0.17 & 0.06 & 2.12 & 0.16 \\
\cline { 2 - 7 } & Habitat*TP & 2 & 0.11 & 0.04 & 0.69 & 0.60 \\
\cline { 2 - 6 } & Slough*Habitat*TP & 2 & 0.10 & 0.04 & 0.65 & 0.64 \\
\cline { 2 - 7 } & Residual & 15 & 1.19 & 0.45 & & \\
\cline { 2 - 6 } & Total & 26 & 2.66 & 1.00 & & \\
\hline
\end{tabular}


Table 11: Count by taxa of aquatic consumers sampled in marsh, near-pond, and pond habitats at ten sites in Taylor Slough and Shark River Slough in the 2018 wet and 2019 dry seasons. Sampling was performed using throw traps, unbaited minnow traps, and drift fences.

\begin{tabular}{|c|c|c|c|}
\hline Taxonomic Phylum & Taxonomic Class & Count & Number of Identified Taxa \\
\hline \multirow{3}{*}{ Arthropoda } & Arachnida & 211 & 2 taxa \\
\cline { 2 - 4 } & Insecta & 1,901 & 21 taxa \\
\cline { 2 - 4 } & Malacostraca & 3,053 & 4 taxa \\
\hline \multirow{3}{*}{ Chordata } & Actinopterygii & 2,571 & 31 species \\
\cline { 2 - 4 } & Amphibia & 50 & 6 species \\
\cline { 2 - 4 } & Reptilia & 5 & 1 species \\
\hline \multirow{2}{*}{ Mollusca } & Bivalvia & 1 & 1 species \\
\cline { 2 - 4 } & Gastropoda & 83 & 6 species \\
\hline \multicolumn{2}{|c|}{ Total } & $\mathbf{7 , 8 7 5}$ & $\mathbf{7 2 ~ t a x a}$ \\
\hline
\end{tabular}


Table 12: Repeated-measures analysis of variance of richness of aquatic consumer communities from throw trap, minnow trap, and drift fence sampling performed in marsh, near-pond, and pond habitats at ten sites in Taylor Slough and Shark River Slough in the 2018 wet and 2019 dry seasons. Datasets were parsed to account for unequal sampling.

\begin{tabular}{|c|c|c|c|c|c|c|c|}
\hline Dataset & Error & Source & df & SSq & MSq & $\mathbf{F}$ & $p$ \\
\hline \multirow{5}{*}{$\begin{array}{c}\text { Both Sloughs, } \\
\text { Wet Season } \\
\text { Only }\end{array}$} & \multirow{2}{*}{ Site } & "Slough & $\overline{11}$ & $\begin{array}{ll}10.8 \\
\end{array}$ & 10.8 & 0.16 & 0.70 \\
\hline & & Residuals & 8 & 558.7 & 69.8 & & \\
\hline & \multirow{3}{*}{ Site*Habitat } & Habitat & 2 & 764.1 & 382.0 & 27.52 & $<0.01$ \\
\hline & & Slough*Habitat & 2 & 21.8 & 10.9 & 0.79 & 0.47 \\
\hline & & Residuals & 16 & 222.1 & 13.9 & & \\
\hline \multirow{7}{*}{$\begin{array}{l}\text { Both Seasons, } \\
\text { Shark River } \\
\text { Slough Only }\end{array}$} & Site & Residuals & 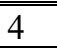 & 200.2 & 50.05 & & \\
\hline & \multirow{2}{*}{ Site*Season } & Season & 1 & 7.5 & 7.5 & 0.12 & 0.76 \\
\hline & & Residuals & 4 & 279.0 & 69.75 & & \\
\hline & \multirow{2}{*}{ Site*Habitat } & Habitat & 2 & 790.1 & 395.0 & 13.08 & $<0.01$ \\
\hline & & Residuals & 8 & 241.6 & 30.2 & & \\
\hline & \multirow{2}{*}{ Site*Habitat*Season } & Season*Habitat & 2 & 127.4 & 63.7 & 10.27 & $<0.01$ \\
\hline & & Residuals & 8 & 49.6 & 6.2 & & \\
\hline
\end{tabular}


Table 13: Estimated marginal least-squares means of aquatic consumer richness for significant effects from throw trap, minnow trap, and drift fence sampling performed in marsh, near-pond, and pond habitats at ten sites in Taylor Slough and Shark River Slough in the 2018 wet and 2019 dry seasons.

\begin{tabular}{|l|l|l|l|l|l|}
\hline Dataset & Contrast & Estimate \pm SE & df & t ratio & $\boldsymbol{p}$ \\
\hline \multirow{3}{*}{$\begin{array}{l}\text { Both Sloughs, } \\
\text { Wet Season Only }\end{array}$} & marsh - near-pond & $0.4 \pm 1.7$ & 18 & 0.24 & 0.97 \\
\cline { 2 - 6 } & marsh - pond & $10.9 \pm 1.7$ & 18 & 6.21 & $<\mathbf{0 . 0 1}$ \\
\cline { 2 - 6 } & near-pond - pond & $10.5 \pm 1.7$ & 18 & 6.38 & $<\mathbf{0 . 0 1}$ \\
\hline \hline \multirow{5}{*}{$\begin{array}{l}\text { Both Seasons, } \\
\text { Shark River }\end{array}$} & marsh, dry - near-pond, dry & $10.0 \pm 2.7$ & 11.2 & 3.71 & $\mathbf{0 . 0 3}$ \\
\cline { 2 - 6 } & marsh, dry - pond, dry & $16.0 \pm 2.7$ & 11.2 & 5.93 & $<\mathbf{0 . 0 1}$ \\
\cline { 2 - 6 } & marsh, dry - marsh, wet & $4.6 \pm 3.3$ & 5.5 & 1.39 & 0.73 \\
\cline { 2 - 6 } & marsh, dry - near-pond, wet & $4.8 \pm 4.0$ & 9.5 & 1.21 & 0.82 \\
\cline { 2 - 6 } & marsh, dry - pond, wet & $13.6 \pm 4.0$ & 9.5 & 3.43 & 0.06 \\
\cline { 2 - 6 } & near-pond, dry - pond, dry & $6.0 \pm 2.7$ & 11.2 & 2.22 & 0.30 \\
\cline { 2 - 6 } & near-pond, dry - marsh, wet & $-5.4 \pm 4.0$ & 9.5 & -1.36 & 0.75 \\
\cline { 2 - 6 } & near-pond, dry - near-pond, wet & $-5.2 \pm 3.3$ & 5.5 & -1.57 & 0.64 \\
\cline { 2 - 6 } & near-pond, dry - pond, wet & $3.6 \pm 4.0$ & 9.5 & 0.91 & 0.94 \\
\cline { 2 - 6 } & pond, dry - marsh, wet & $-11.4 \pm 4.0$ & 9.5 & -2.87 & 0.13 \\
\cline { 2 - 6 } & pond, dry - near-pond, wet & $-11.2 \pm 4.0$ & 9.5 & -2.82 & 0.14 \\
\cline { 2 - 6 } & pond, dry - pond, wet & $-2.4 \pm 3.3$ & 5.5 & -0.73 & 0.97 \\
\cline { 2 - 6 } & marsh, wet - near-pond, wet & $0.2 \pm 2.7$ & 11.2 & 0.07 & 1.00 \\
\cline { 2 - 6 } & marsh, wet - pond, wet & $9.0 \pm 2.7$ & 11.2 & 3.34 & 0.06 \\
\cline { 2 - 6 } & near-pond, wet - pond, wet & $8.8 \pm 2.7$ & 11.2 & 3.26 & 0.06 \\
\hline
\end{tabular}


Table 14: Permutational multivariate analysis of variance results from Morisita-Horn dissimilarity matrix of aquatic consumer communities from throw trap, minnow trap, and drift fence sampling performed in marsh, near-pond, and pond habitats at ten sites in Taylor Slough and Shark River Slough in the 2018 wet and 2019 dry seasons.

\begin{tabular}{|l|l|l|l|l|l|l|}
\hline Dataset & Source & df & SS & $\mathbf{R}^{\mathbf{2}}$ & $\mathbf{F}$ & $\boldsymbol{p}$ \\
\hline \multirow{4}{*}{$\begin{array}{l}\text { Both Sloughs, } \\
\text { Wet Season Only }\end{array}$} & Slough & 1 & 0.28 & 0.07 & 3.92 & $\mathbf{0 . 0 1}$ \\
\cline { 2 - 7 } & Habitat & 2 & 1.22 & 0.30 & 8.71 & $<\mathbf{0 . 0 1}$ \\
\cline { 2 - 7 } & Slough*Habitat & 2 & 1.01 & 0.25 & 7.20 & $<\mathbf{0 . 0 1}$ \\
\cline { 2 - 7 } & Residual & 23 & 1.61 & 0.39 & & \\
\cline { 2 - 7 } & Total & 28 & 4.12 & 1.00 & & \\
\hline \hline \multirow{4}{*}{$\begin{array}{l}\text { Both Sloughs, } \\
\text { Wet Season Only }\end{array}$} & Slough & 1 & 0.28 & 0.07 & 3.82 & $\mathbf{0 . 0 2}$ \\
\cline { 2 - 7 } & Habitat & 2 & 1.22 & 0.30 & 8.50 & $<\mathbf{0 . 0 1}$ \\
\cline { 2 - 7 } & TP & 1 & 0.01 & 0.00 & 0.18 & 0.89 \\
\cline { 2 - 7 } & Slough*Habitat & 2 & 1.06 & 0.26 & 7.33 & $<\mathbf{0 . 0 1}$ \\
\cline { 2 - 7 } & Slough*TP & 1 & 0.06 & 0.02 & 0.89 & 0.43 \\
\cline { 2 - 7 } & Slough*Habitat*TP & 2 & 0.12 & 0.03 & 0.81 & 0.56 \\
\cline { 2 - 7 } & Residual & 17 & 1.22 & 0.04 & 1.07 & 0.40 \\
\cline { 2 - 7 } & Total & 28 & 4.12 & 1.00 & & \\
\hline \hline \multirow{3}{*}{$\begin{array}{l}\text { Both Seasons, } \\
\text { Shark River } \\
\text { Slough Only }\end{array}$} & Season & 1 & 0.04 & 0.02 & 0.57 & 0.67 \\
\cline { 2 - 5 } & Habitat & 2 & 0.50 & 0.20 & 3.43 & $<\mathbf{0 . 0 1}$ \\
\cline { 2 - 7 } & Season*Habitat & 2 & 0.34 & 0.13 & 2.32 & $\mathbf{0 . 0 2}$ \\
\cline { 2 - 7 } & Residual & 23 & 1.68 & 0.66 & & \\
\cline { 2 - 7 } & Total & 28 & 2.56 & 1.00 & & \\
\hline
\end{tabular}


Figure 1: Alligator pond sites in Taylor Slough and Shark River Slough, Everglades, Florida, USA in the 2018 wet and 2019 dry seasons.

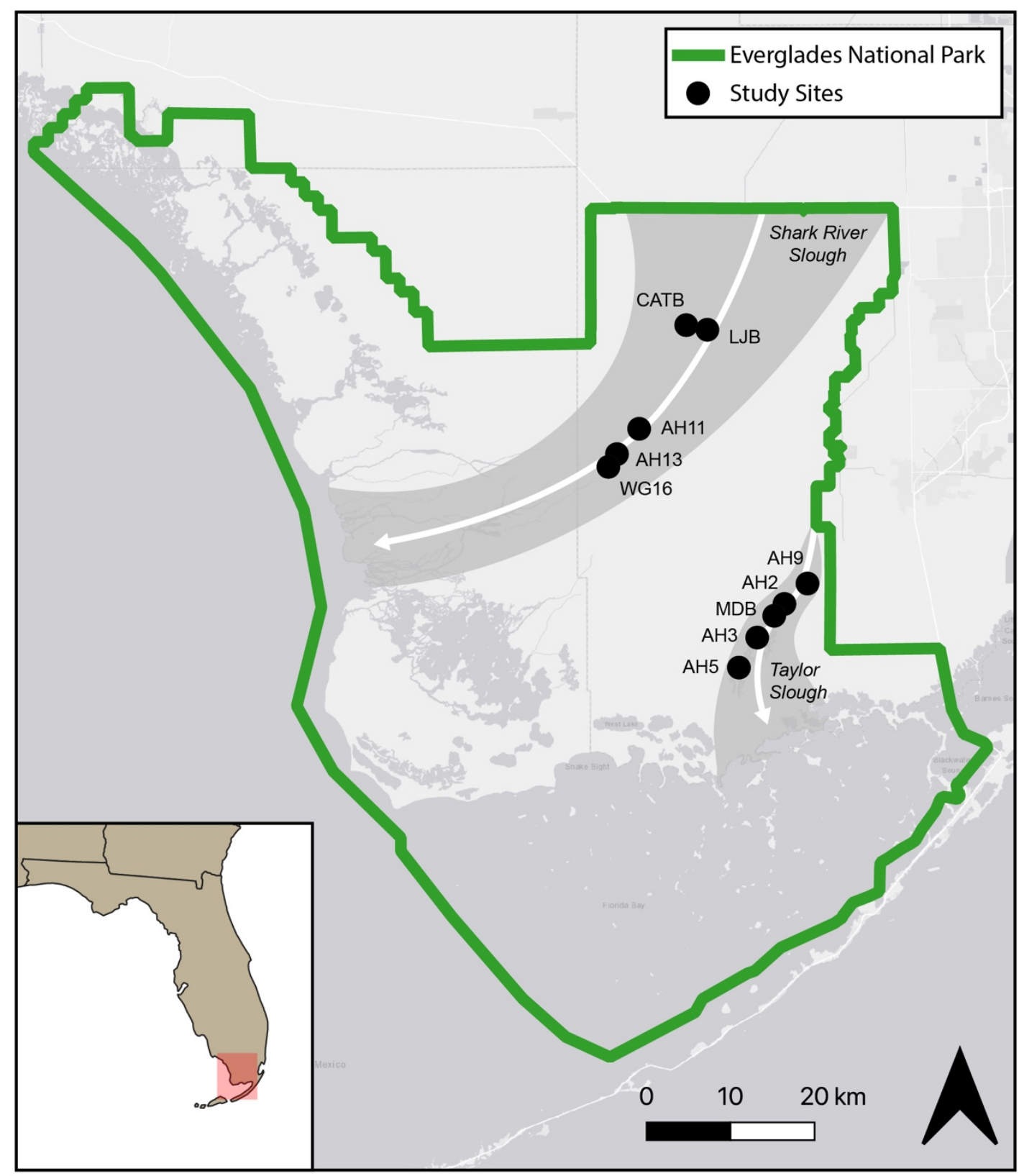


Figure 2: Water-column total phosphorus for marsh, near-pond, and pond habitats at ten sites in Taylor Slough and Shark River Slough in the 2018 wet and 2019 dry seasons. Wet season site MDB for the near-pond was an extreme outlier at $30.85 \mu \mathrm{mol} / \mathrm{L}$ and was not plotted. The near-pond habitat was not sampled during the dry season because of marsh drydown.

Wet Season

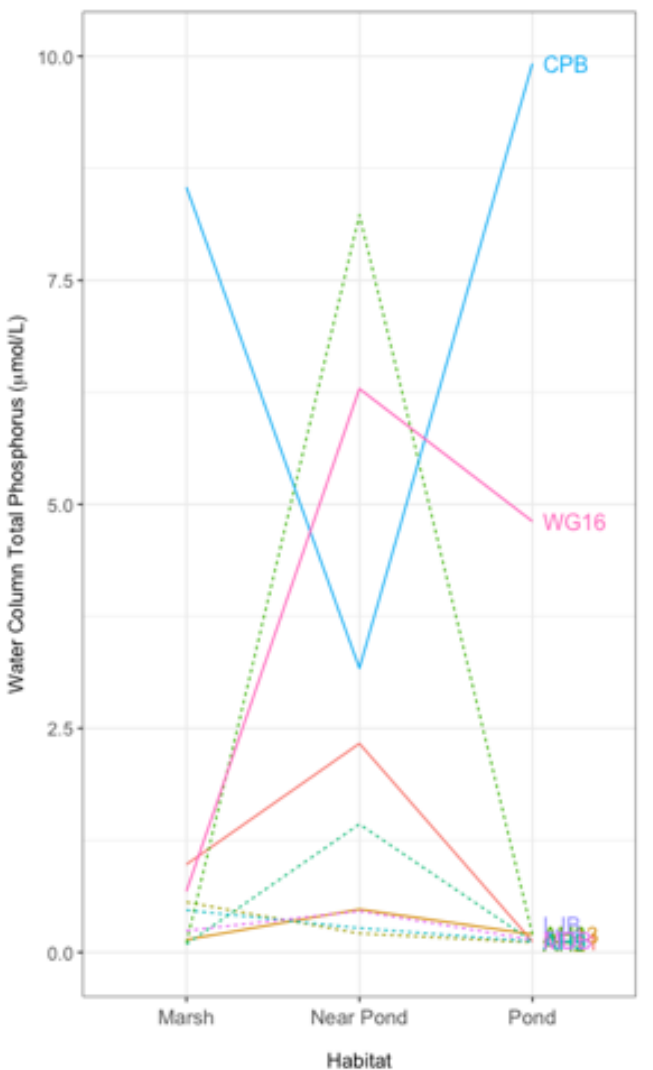

Dry Season

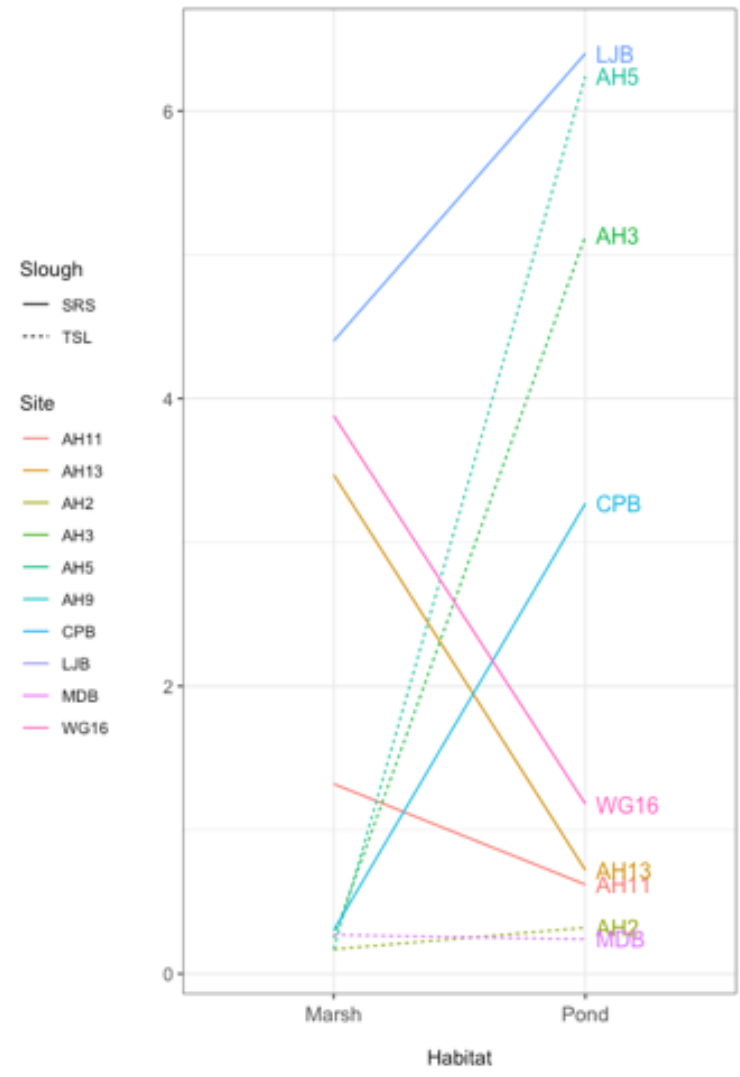


Figure 3: Floc total phosphorus for marsh, near-pond, and pond habitats at ten sites in Taylor Slough and Shark River Slough in the 2018 wet season.

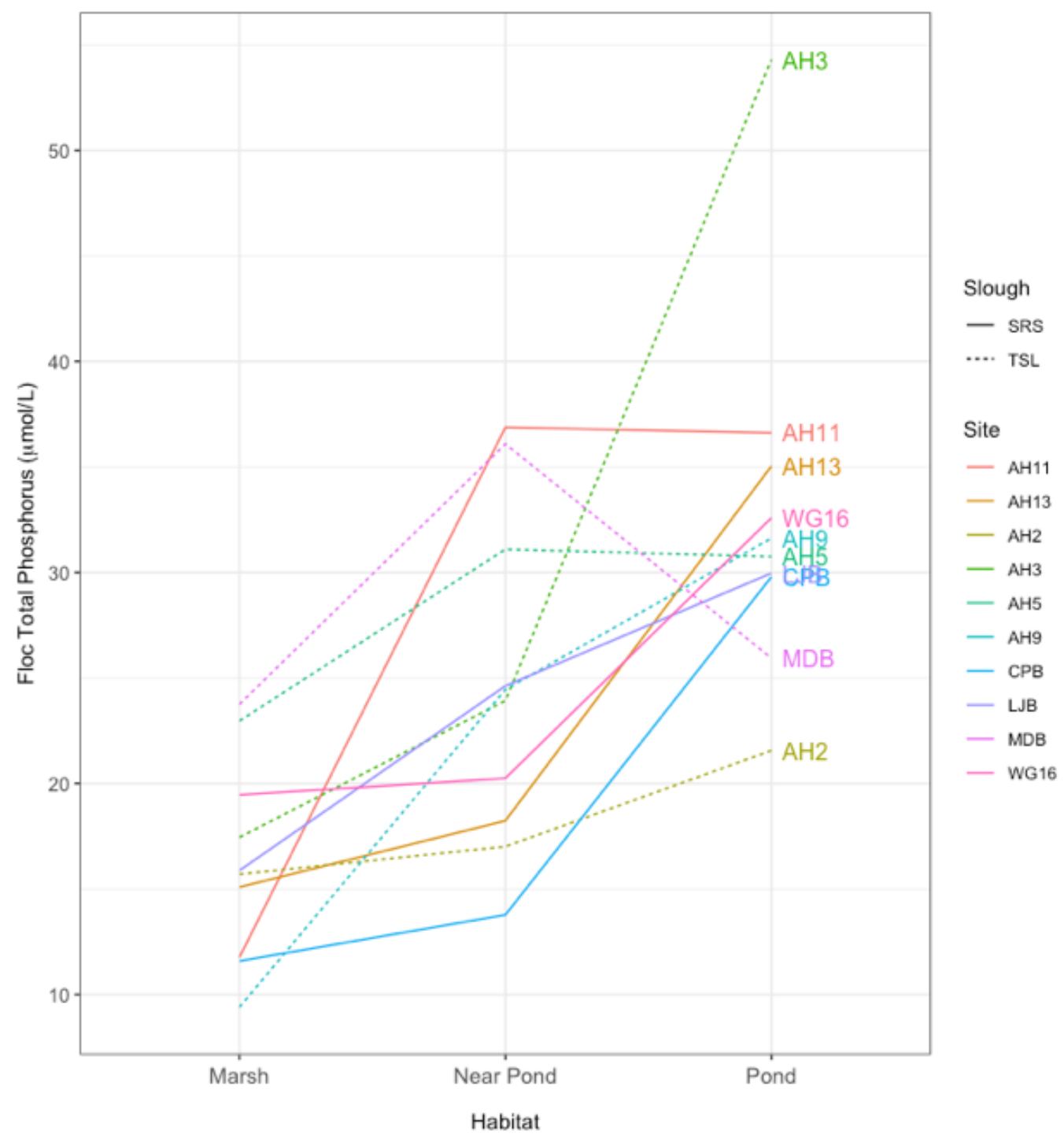


Figure 4: Non-metric multidimensional scaling biplot revealing plant compositional similarity among marsh, near-pond, and pond habitats. Sampling was performed at ten sites in Taylor Slough (represented by a circle) and Shark River Slough (square) in the 2018 wet (green) and 2019 dry (brown) seasons. Ellipses represent 1 standard deviation and are outlined and shaded to represent habitats: pond (blue), near-pond (green), and marsh (brown). Generally, taxa are abbreviated in the plot as the first three letters of genus and species. Taxa are abbreviated in the plot as the first three letters of genus followed by first three letters of species.

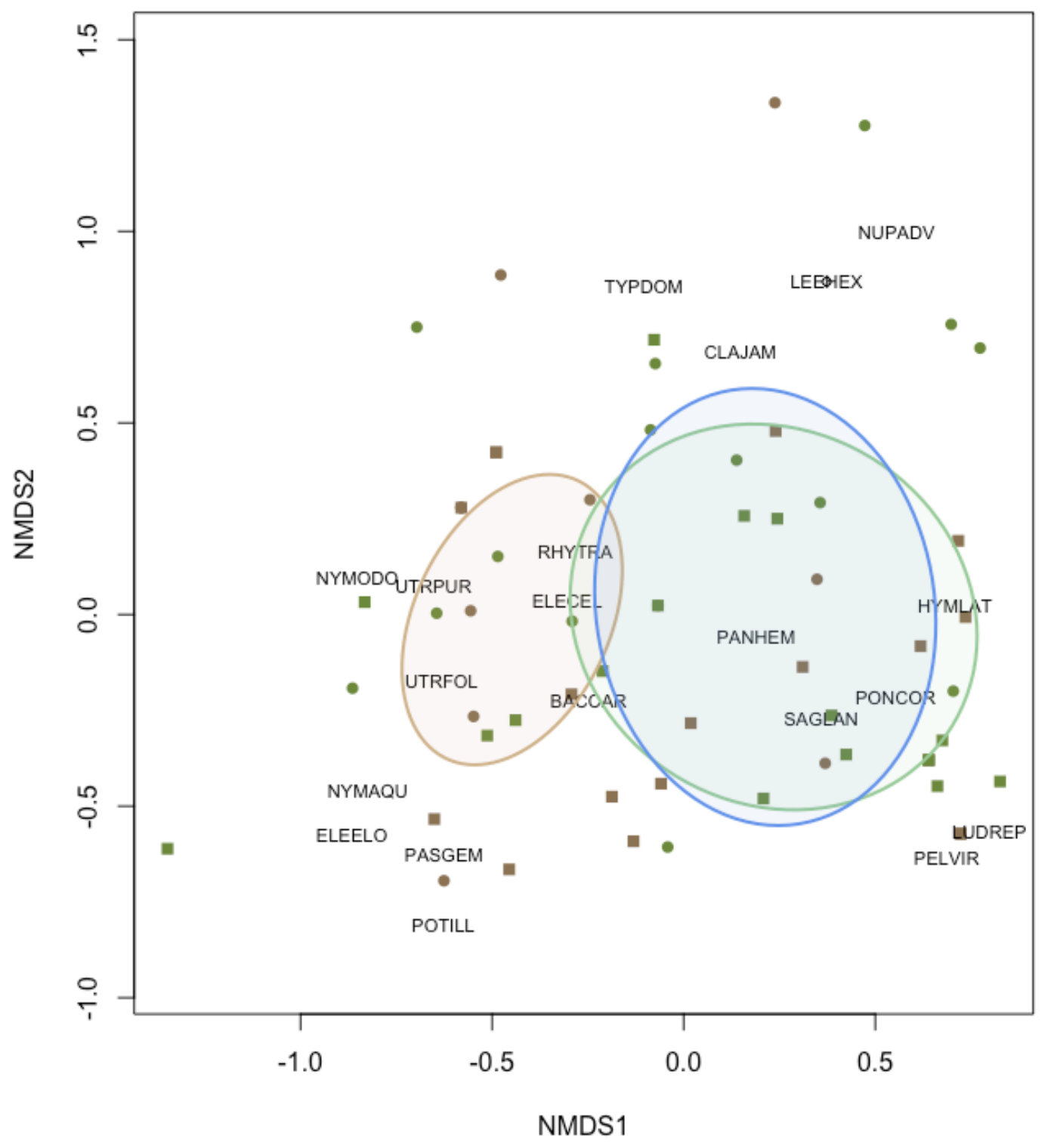


Figure 5: Rarefaction curves for benthic invertebrate communities from funnel trap sampling performed in marsh, near-pond, and pond habitats at ten sites in Taylor Slough and Shark River Slough in the 2018 wet and 2019 dry seasons.

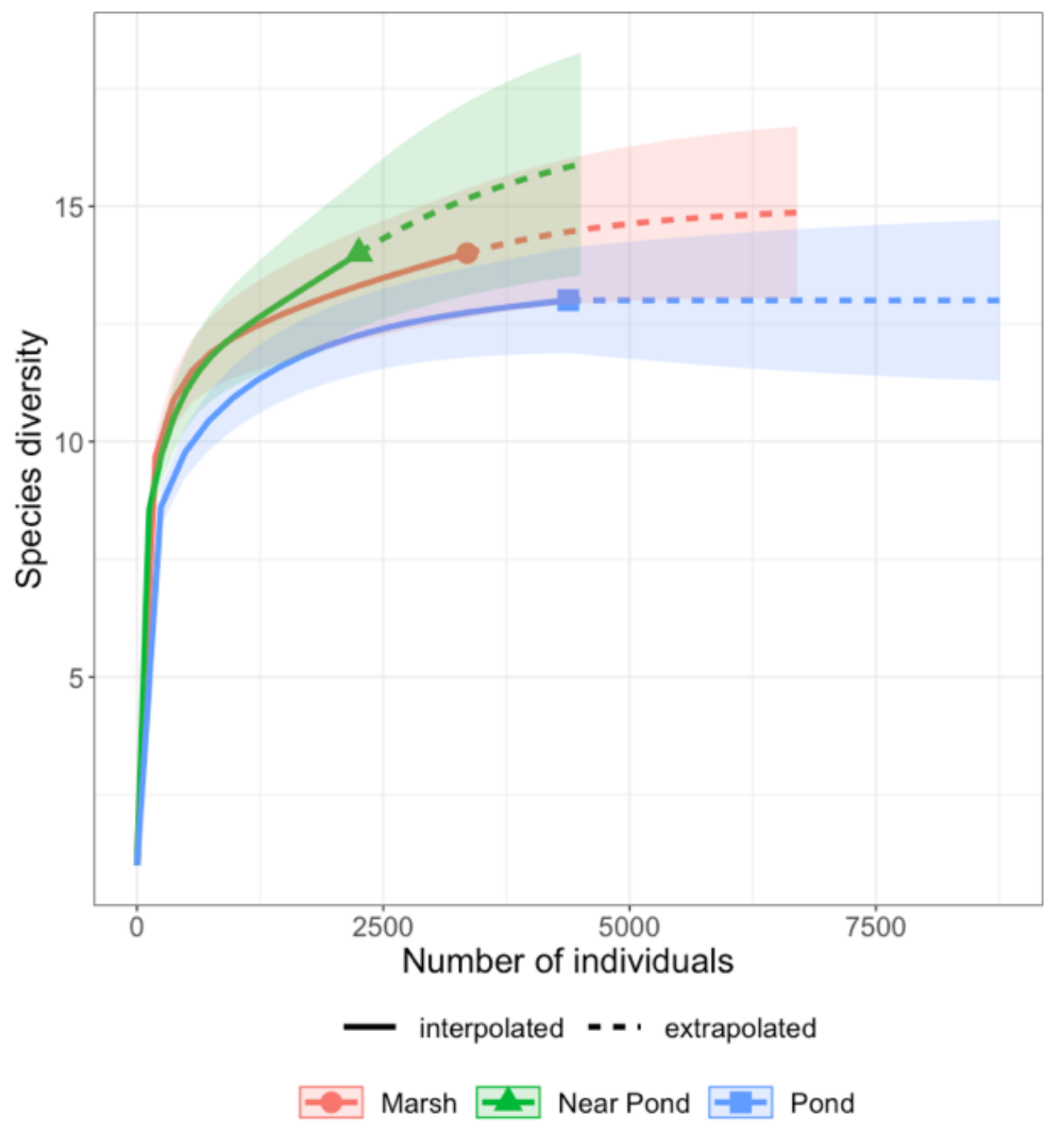


Figure 6: Dominance-diversity curves for mean CPUE $(1,000 \mathrm{~mL})$ of benthic invertebrate communities from funnel trap sampling performed in marsh, near-pond, and pond habitats at ten sites in Taylor Slough and Shark River Slough in the 2018 wet and 2019 dry seasons. Taxa are abbreviated in the plot as the first four letters: Copepoda, Ostracoda, Mollusca, Cladocera, Amphipoda, Diptera, Ephemeroptera, Nematoda, Platyhelminthes, Hemiptera, Odonata, and Trombidiformes.

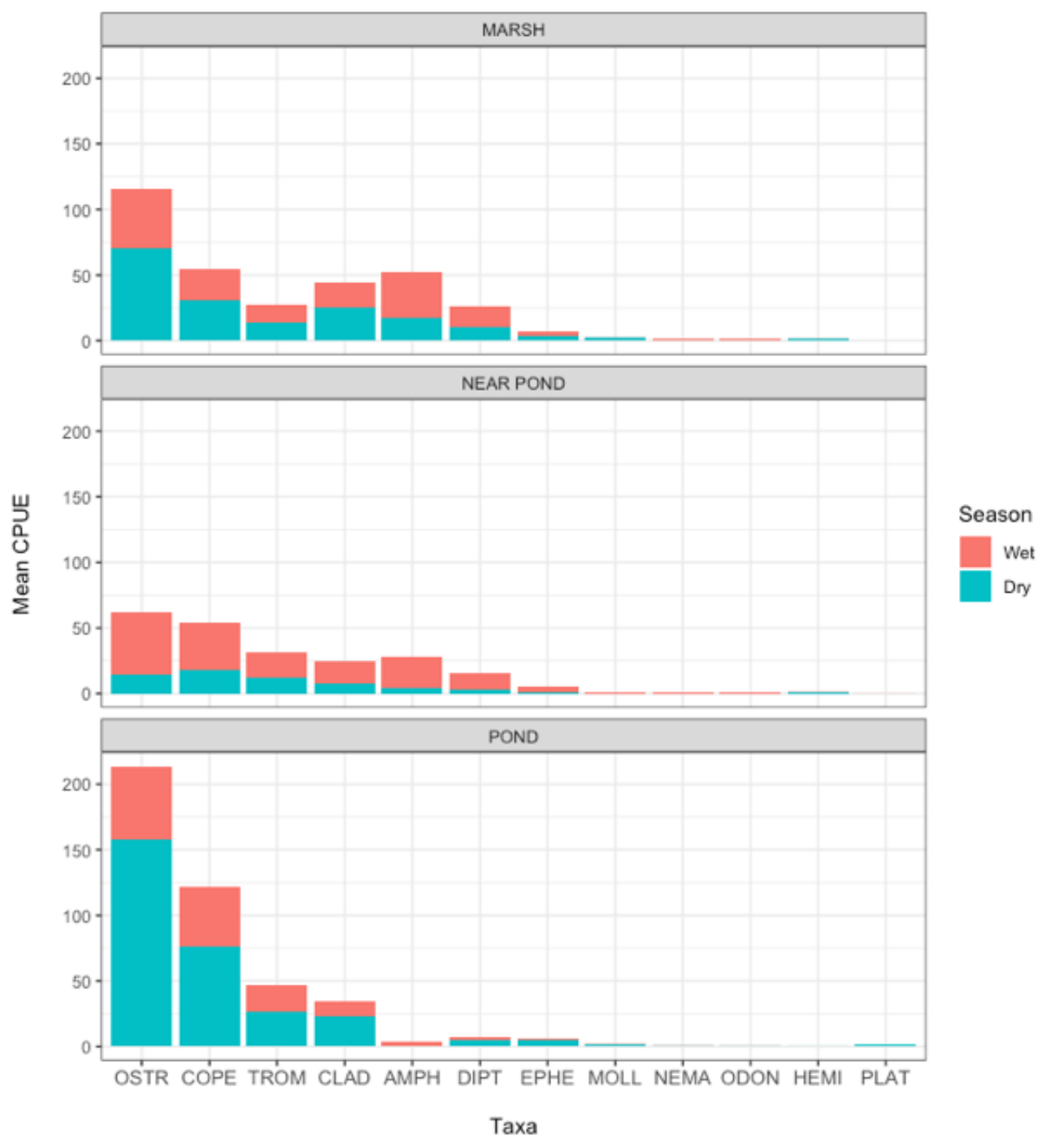


Figure 7: Non-metric multidimensional scaling biplot revealing benthic invertebrate compositional similarity among marsh, near-pond, and pond habitats. Funnel trap sampling was performed at ten sites in Taylor Slough (represented by a circle) and Shark River Slough (square) in the 2018 wet (green) and 2019 dry (brown) seasons. Ellipses represent 1 standard deviation and are outlined and shaded to represent habitats: pond (blue), near-pond (green), and marsh (brown). Generally, taxa are abbreviated in the plot as the first three letters of genus and species. Taxa are abbreviated in the plot as the first four letters: Copepoda, Ostracoda, Mollusca, Cladocera, Amphipoda, Diptera, Ephemeroptera, Nematoda, Platyhelminthes, Hemiptera, Odonata, and HYDR = Trombidiformes.

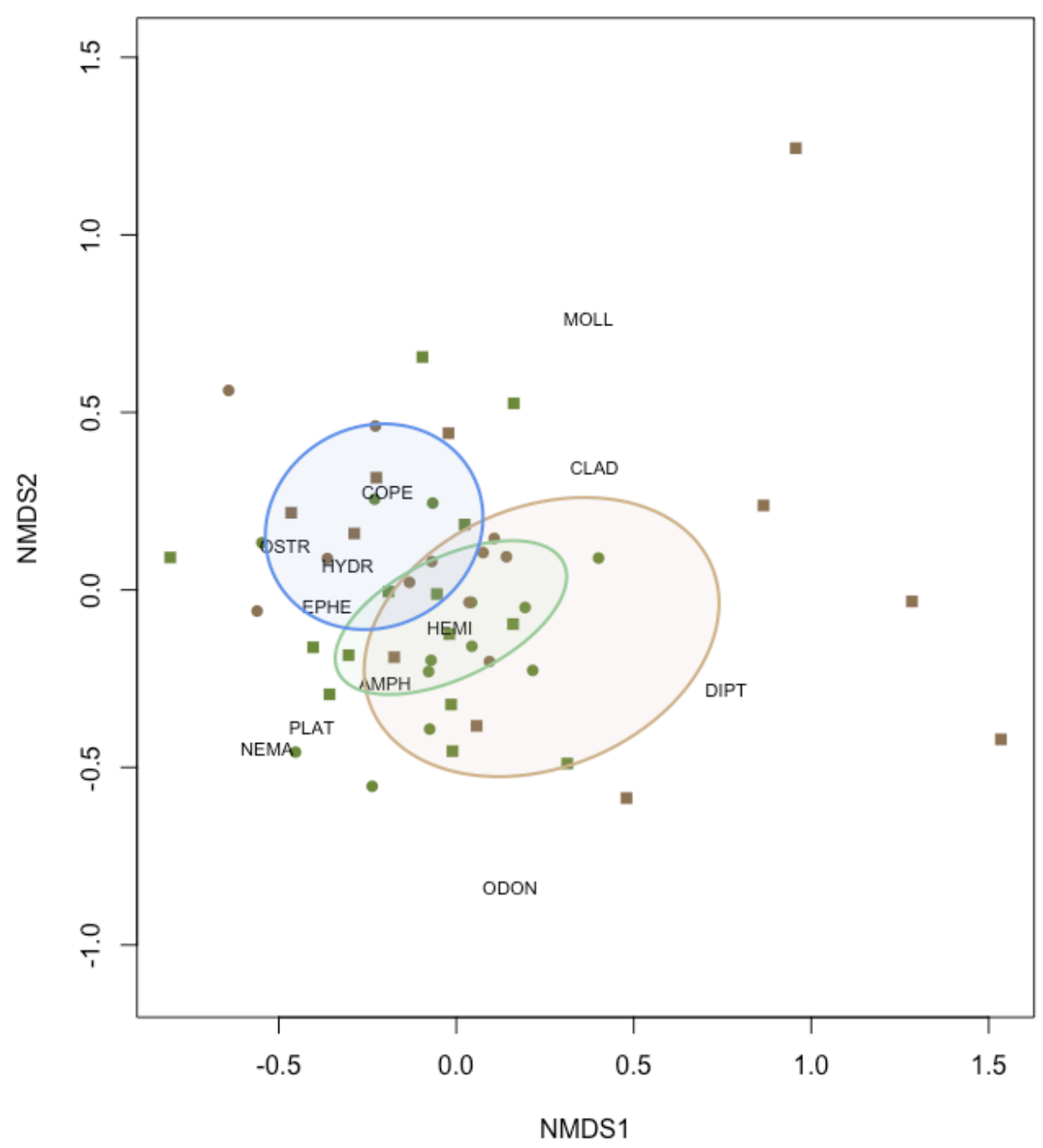


Figure 8: Rarefaction curves of aquatic consumer communities from throw trap, minnow trap, and drift fence sampling performed in marsh, near-pond, and pond habitats at ten sites in Taylor Slough and Shark River Slough in the 2018 wet and 2019 dry seasons.

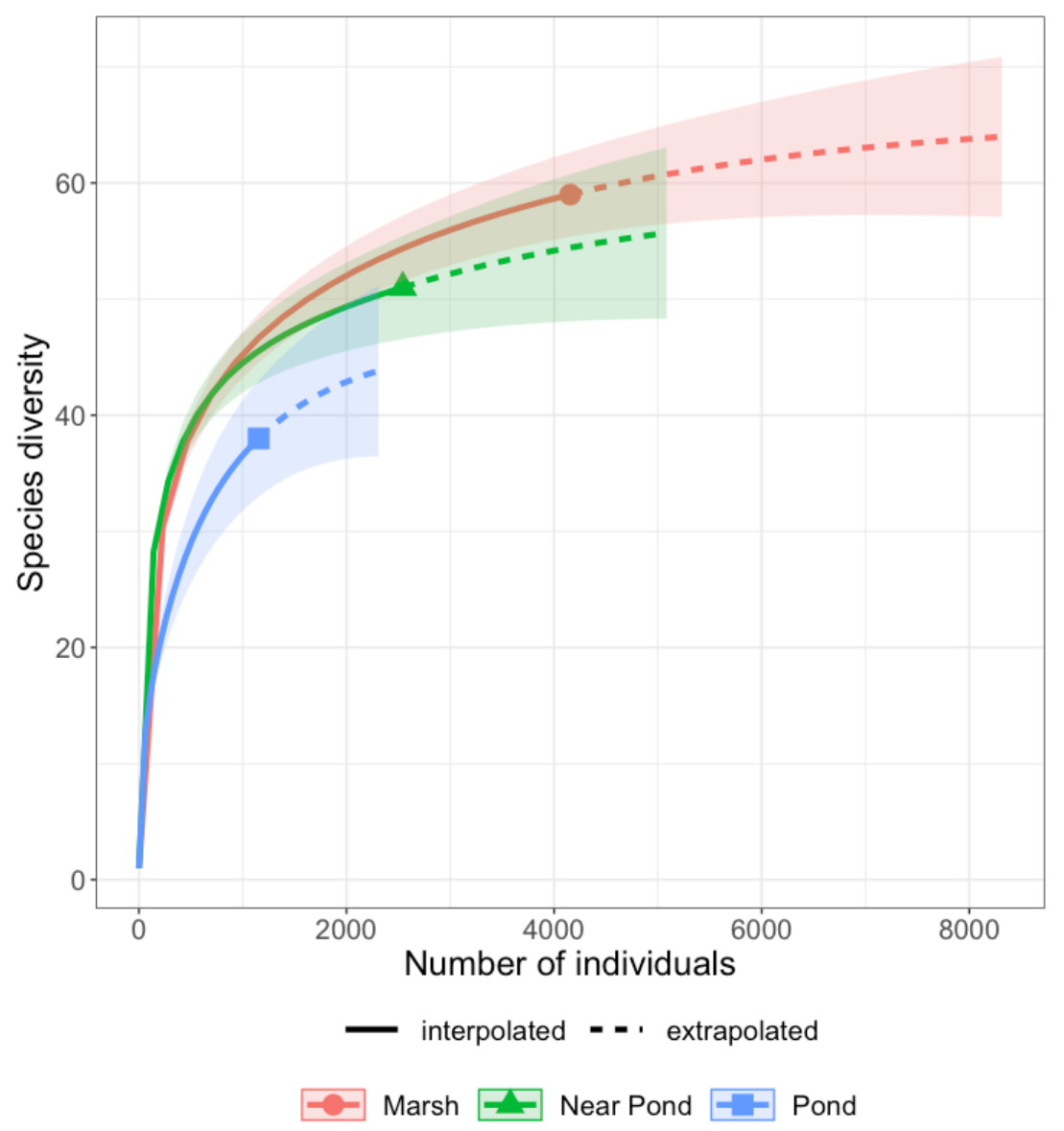


Figure 9: Dominance-diversity curves for mean relative abundance of aquatic consumer communities from throw trap, minnow trap, and drift fence sampling performed in marsh, near-pond, and pond habitats at ten sites in Taylor Slough and Shark River Slough in the 2018 wet and 2019 dry seasons. Generally, taxa are abbreviated in the plot as the first three letters of genus and species.

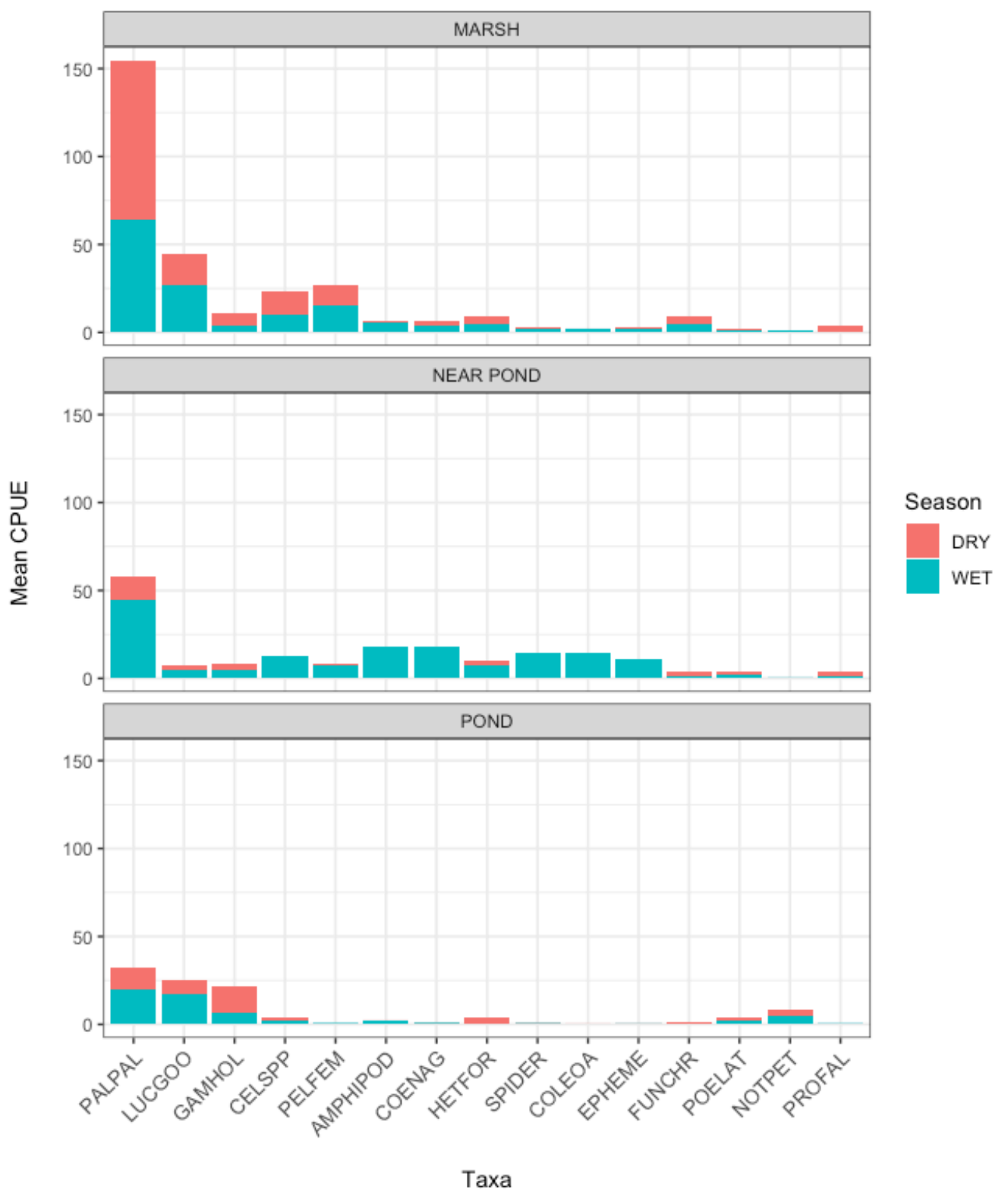


Figure 10: Dominance-diversity curves for mean catch per unit effort $\left(3 \times 1 \mathrm{~m}^{3}\right)$ of aquatic consumer communities from throw trap sampling performed in marsh, near-pond, and pond habitats at ten sites in Taylor Slough and Shark River Slough in the 2018 wet and 2019 dry seasons. Generally, taxa are abbreviated in the plot as the first three letters of genus and species.

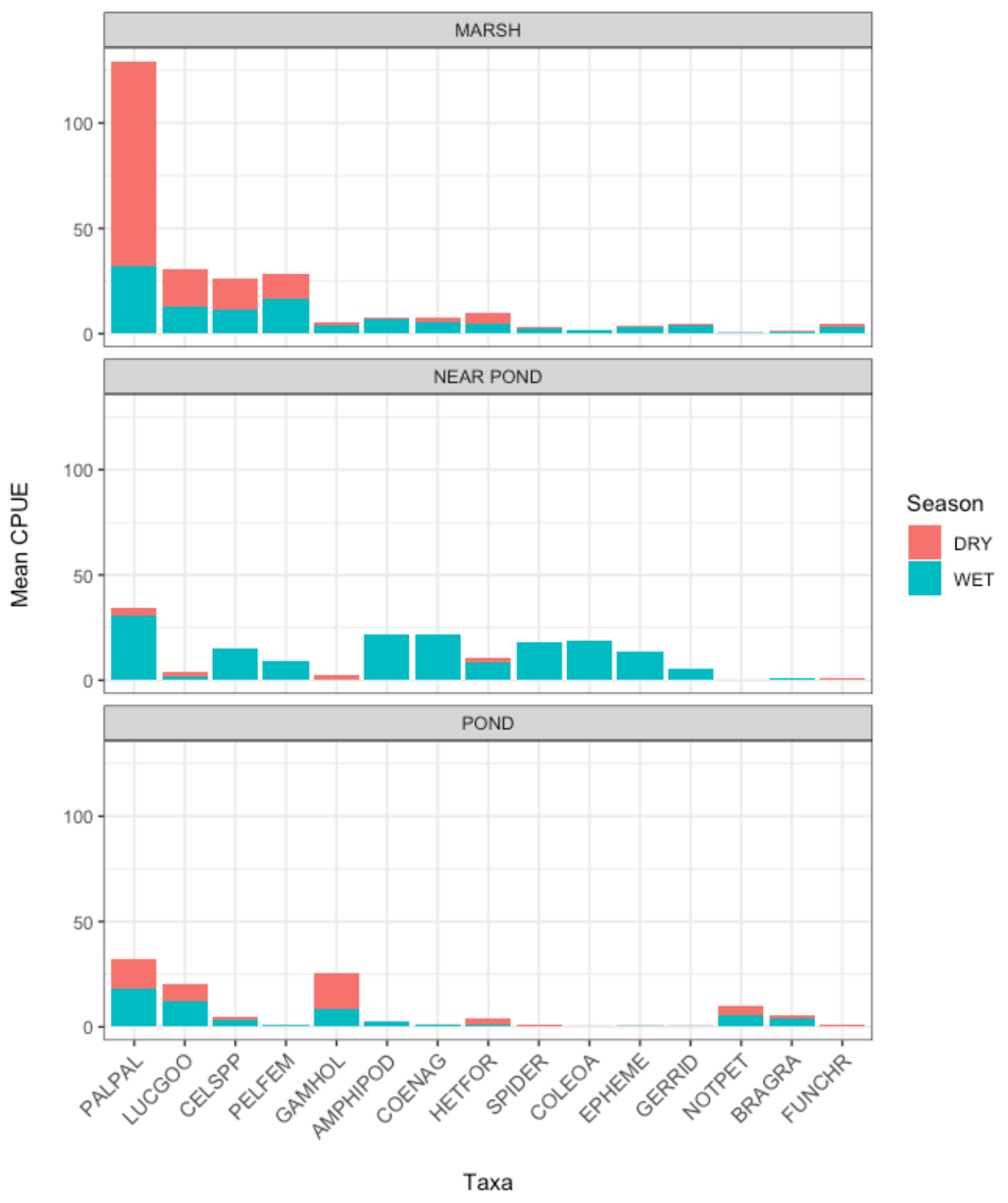


Figure 11: Dominance-diversity curves for mean catch per unit effort of aquatic consumer communities from un-baited minnow trap sampling performed in marsh, nearpond, and pond habitats at ten sites in Taylor Slough and Shark River Slough in the 2018 wet and 2019 dry seasons. Generally, taxa are abbreviated in the plot as the first three letters of genus and species.

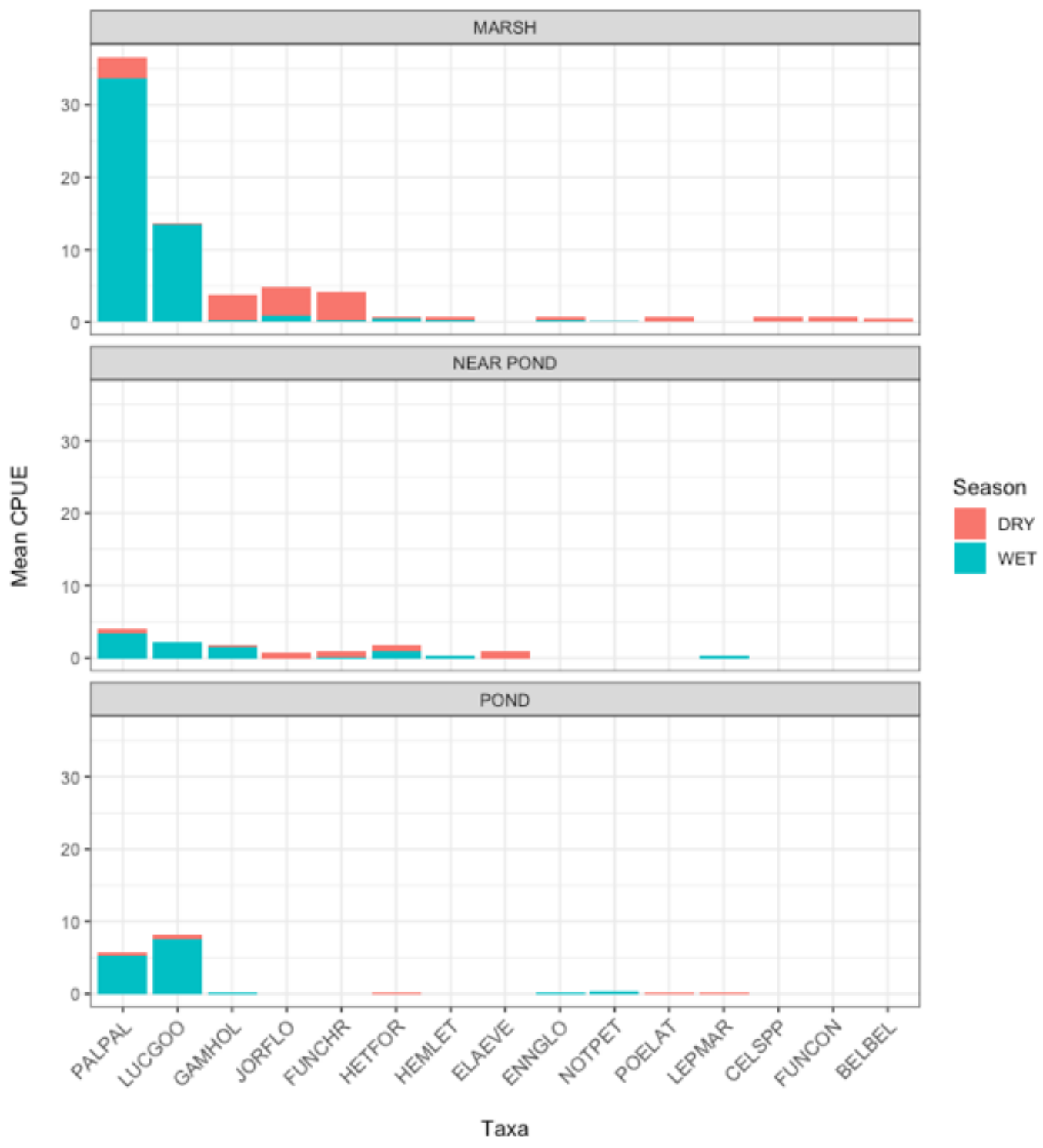


Figure 12: Dominance-diversity curves for mean catch per unit effort of aquatic consumer communities from drift fence sampling performed in marsh and near-pond habitats at ten sites in Taylor Slough and Shark River Slough in the 2018 wet and 2019 dry seasons. Generally, taxa are abbreviated in the plot as the first three letters of genus and species.

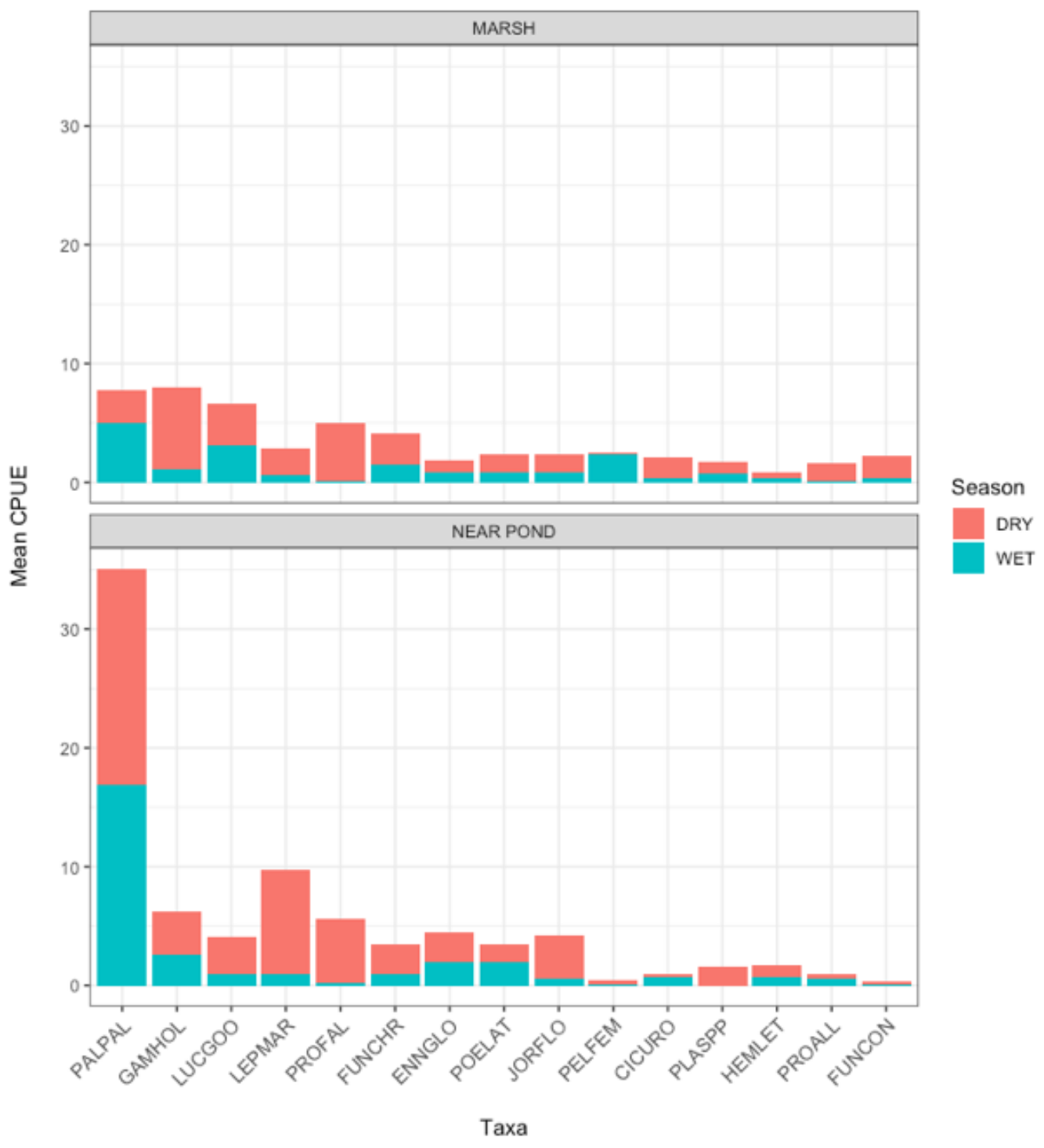


Figure 13: Non-metric multidimensional scaling biplot revealing aquatic consumer compositional similarity among marsh, near-pond, and pond habitats from throw trap, minnow trap, and drift fence sampling performed at five sites in Shark River Slough in the 2018 wet (green) and 2019 dry seasons (brown). Ellipses represent 1 standard deviation and are outlined and shaded to represent habitats: pond (blue), near-pond (green), and marsh (brown). Generally, taxa are abbreviated in the plot as the first three letters of genus and species.

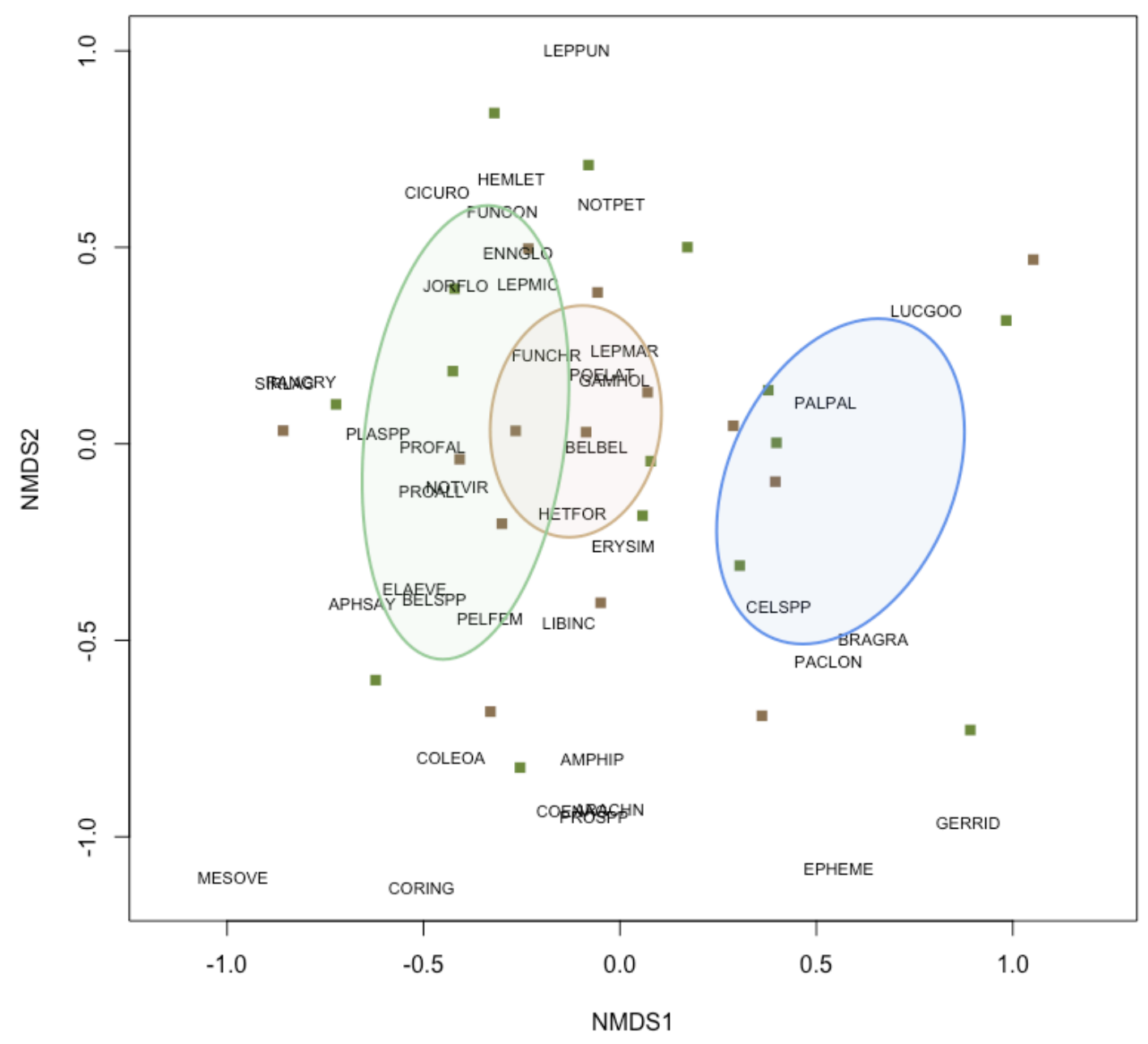


Table A1: Aquatic consumers captured from throw trap, minnow trap, and drift fence sampling performed in marsh, near-pond, and pond habitats at ten sites in Taylor Slough and Shark River Slough, Everglades, Florida, USA in the 2018 wet and 2019 dry seasons.

\begin{tabular}{|c|c|c|c|}
\hline Common Name & Scientific Name & Brook Silverside & Labidesthes sicculus \\
\hline Spider & Araneae & Inland Silverside & Menidia beryllina \\
\hline Aquatic mite & Hydrachnidia & Black Acara & Cichlasoma bimaculatum \\
\hline Water tiger & Cybister spp. & African Jewelfish & Hemichromis letourneuxi \\
\hline Aquatic beetles & Coleoptera & Mayan Cichlid & Cichlasoma (Mayaheros) urophthalmus \\
\hline Midge larvae & Chironomidae & Jaguar Guapote & $\begin{array}{l}\text { Cichlasoma manguense } \\
\text { (Parachromis managuensis) }\end{array}$ \\
\hline Horse and deer fly larvae & Tabanidae & Spotted Tilapia & Tilapia (Pelmatolapia) mariae \\
\hline Mayfly larvae & Ephemeroptera & Lake Chubsucker & Erimyzon sucetta \\
\hline Giant water bug & Belostoma spp. & Coastal Shiner & Notropis petersoni \\
\hline Water boatmen & Corixidae & Sheepshead Minnow & Cyprinodon variegatus \\
\hline Water striders & Gerridae & Flagfish & Jordanella floridae \\
\hline Water treaders & Mesoveliidae & Golden Topminnow & Fundulus chrysotus \\
\hline Creeping water bug & Pelocoris femoratus & Marsh Killifish & Fundulus confluentus \\
\hline Regal darner & Coryphaeschna ingens & Bluefin Killifish & Lucania goodei \\
\hline Damselfly larvae & Coenagrionidae & Pike Killifish & Belonesox belizanus \\
\hline Florida baskettail & Epitheca stella & Eastern Mosquitofish & Gambusia holbrooki \\
\hline Four-spotted pennant & Brachymesia gravida & Least Killifish & Heterandria formosa \\
\hline Pennants & Celithemis spp. & Sailfin Mollie & Poecilia latipinna \\
\hline Eastern pondhawk & Erythemis simplicicollis & Bluespotted Sunfish & Enneacanthus gloriosus \\
\hline Golden-winged skimmer & Libellula auripennis & Warmouth & Lepomis gulosus \\
\hline Slaty skimmer & Libellula incesta & Bluegill Sunfish & Lepomis macrochirus \\
\hline Blue dasher & Pachydiplax longipennis & Dollar Sunfish & Lepomis marginatus \\
\hline Cricket & Gryllidae & Redear Sunfish & Lepomis microlophus \\
\hline Grasshopper & Orthoptera & Spotted Sunfish & Lepomis punctatus \\
\hline Unidentified insect & Insecta & Everglades Pygmy Sunfish & Elassoma evergladei \\
\hline Scuds & Amphipoda & Pirate Perch & Aphredoderus sayanus \\
\hline Grass shrimp & Palaemonetes paludosus & Yellow Bullhead & Ameiurus natalis \\
\hline Everglades crayfish & Procambarus alleni & Brown Bullhead & Ameiurus nebulosus \\
\hline Slough crayfish & Procambarus fallax & Tadpole Madtom & Noturus gyrinus \\
\hline Unidentified crayfish & Procambarus spp. & Spotfin Spiny Eel & Macrognathus siamensis \\
\hline Fingernail pea clam & Sphaerium spp. & Asian Swamp Eel & Monopterus albus \\
\hline Spiketop applesnail & Pomacea bridgesii & Cricket frog & Acris gryllus \\
\hline Florida applesnail & Pomacea paludosa & Pig frog & Rana grylio \\
\hline Mimic pond snail & Pseudosuccinea columella & Two-toed amphiuma & Amphiuma means \\
\hline Physid snail & Haitia spp. & Peninsula newt & Notophthalmus viridescens \\
\hline Mesa ramshorn & Planorbella scalaris & Everglades dwarf siren & Pseudobranchus axanthus \\
\hline Planorbellid snail & Planorbella spp. & Greater siren & Siren lacertina \\
\hline Red-rimmed melania & Melanoides tuberculata & Florida green water snake & Nerodia floridana \\
\hline
\end{tabular}




\section{CHAPTER V}

FATTY ACIDS REVEAL SHIFTS IN DETRITAL AND ALGAL ENERGY PATHWAYS OF PONDS ENGINEERED BY AMERICAN ALLIGATORS IN AN OLIGOTROPHIC WETLAND 


\begin{abstract}
The source of organic material and energy in food webs can be placed on a continuum of "green" (primary producers) and "brown" (detritus). Oligotrophic wetlands are generally more detrital, but nutrient enrichment and habitat heterogeneity may affect the growth and response of algae and other primary producers. American alligators (Alligator mississippiensis) can influence both the nutrient status and trophic structure of wetlands in the Florida Everglades by creating and maintaining "alligator ponds." We used fatty acid biomarkers to detect the origin of organic matter and the pathways of energy flow on basal food-web resources and three abundant consumers in three distinct habitats related to alligator ponds at ten sites. Algae provided greater contributions to food webs in alligator-engineered ponds compared to marshes where the flocculentdetrital layer was more important. This suggests that, through the creation of ponds, alligators may induce changes in ecosystem function by shifting energy channels toward algal production and away from detrital pathways. However, both the flocculent detrital layer and periphyton are important food-web components and sources of organic material. Algal and bacterial sources were both important sources of energy and macronutrients for each consumer studied, but it is unclear whether these markers are obtained by feeding directly on floc or periphyton or indirectly through their prey. Vascular plants, in contrast, appear to be integrated into the food web primarily by decomposition in floc as detritus. We found no differences of fatty acid profiles of the three consumer species collected across the habitats, which may indicate potential trophic connectivity through animal movement or some other mechanism.
\end{abstract}




\section{Introduction}

"Green" food webs are driven by primary production from living plants or algae which then feed herbivores that are eaten by other consumers (Polis and Strong 1996). In contrast, the energy in "brown" food webs is supplied by decaying debris or "detritus," which may come from dead organisms including unconsumed producers (Moore et al. 2004). In detrital food webs, microflora consume and break down detritus and, in turn, these decomposers are eaten by other consumers (Moore et al. 2004). Some wetlands are characterized as brown food webs with more energy in detrital pathways than in primary production (e.g., Kwak and Zedler 1997; Longhi et al. 2008; Hart and Lovvorn 2003). Generally, wetland microbial communities are often dominated by heterotrophic bacteria, fungi, and other saprophytes that feed on detritus which then provides considerable energy for consumers (DeAngelis et al. 1998; Williams and Trexler 2006). This dichotomy of brown versus green may be an oversimplification of the way that organic matter moves through food webs (Taylor and Batzer 2010; Belicka et al. 2012). In fact, many wetland food webs likely exist in a continuum that follows local heterogeneity in abiotic conditions and seasonal shifts in production. For instance, in areas of the oligotrophic freshwater Everglades marsh where even minor P loading occurs, patches may have enhanced primary production and thus more algal- rather than detrital-energy contributions compared to the marsh (Gaiser et al. 2005; Heymans et al. 2002). Determining the basal sources and flow of energy in food webs is important to understanding ecological processes surrounding trophic structure, ecosystem function, and biodiversity (Moore et al. 2004). It also is important to recognize the factors regulating the continuum of detrital and algal energy sources (Zou et al. 2016). 
The ability of animals to influence nutrient limitation and habitat for basal autotrophic resources is well-established. Generally, two mechanisms predominate in animal-mediated bottom up effects on food webs. First, consumers may translocate nutrients across ecosystem boundaries and can recycle nutrients within habitats. In addition, consumers may affect these processes indirectly by inducing behavioral shifts in other taxa that serve as nutrient vectors (Polis et al. 1997; Schmitz et al. 2010). By recycling and translocating nutrients consumers can significantly alter energy and material fluxes and subsidize primary productivity (Elser and Urabe 1999, Flecker et al. 2002; Roman and McCarthy 2010). Second, consumers may engage in activities that physically modify ecosystems in a process often called "engineering" (Sanders et al. 2014). Physical alterations can be to biotic or abiotic materials and result in changes in how matter moves through environments or transfer materials from the bottom-up to primary producers (Wright et al. 2002, Wright and Jones 2006).

American alligators (Alligator mississippiensis) are abundant predators in the Everglades that may be capable of producing significant bottom-up effects. To illustrate, alligators may affect nutrient cycling by facilitating nutrient transport across productivity gradients (Rosenblatt and Heithaus 2011) and the aquatic-terrestrial matrix (Subalusky et al. 2009) through cross-ecosystem movements. Additionally, alligators can physically engineer the environment by creating ponds, trails, nests, dens, and slides. By creating and maintaining "alligator ponds" in the Florida Everglades alligators may disturb soil and sediment and impact the establishment of plants and the distribution and regeneration of nutrients (Kushlan and Hunt 1979, Campbell and Mazzotti 2004; Palmer and Mazzotti 2004). We hypothesize that these activities in the short term release more labile nutrient 
forms and result in an initial increase in primary productivity through the growth of algae. Indeed, alligator ponds have higher nutrient loadings of P (Chapter 4). In the long term, we predict that basal resource community composition will eventually shift from detrital to algal dominance with continued nutrient enrichment.

A growing body of work suggests that alligator-engineered ponds may be ecologically important by providing nutrient subsidies to an oligotrophic system, habitat heterogeneity to ridge and slough wetlands, and refuges for other fauna during seasonal disturbances (Chapter 4; Kushlan and Hunt 1979; Palmer and Mazzotti 2004). For example, there are differences in community structure across habitats associated with alligator ponds and some ponds are phosphorus-enriched relative to the surrounding marsh (Chapter 4). In this chapter, I test the hypothesis that alligator-engineered ponds have shifted ecosystem function towards increased production with a "greening" of the food web.

Fatty acid biomarker analysis is an informative tool to determine the source and pathway of organic matter in food webs (Iverson et al. 2004; Dalsgaard et al. 2003). Fatty acids can be used as source-specific biomarkers to quantify and trace the contribution of algal-, vascular plant-, fungi-, and bacterial-synthesized fatty acids since some fatty acids are relatively unmodified in the tissues of consumers (Belicka et al. 2012). Here, I use fatty acid biomarkers, to elucidate the origin of organic matter and the pathway of energy flow in Everglades freshwater aquatic food webs in marshes and habitats associated with alligator ponds. 


\section{Methods}

Study site and design

Shark River Slough and Taylor Slough, in Everglades National Park, are the two major drainage basins of freshwater through the Everglades to the Gulf of Mexico. Taylor Slough is a smaller, drier conduit than Shark River Slough (Kotun and Renshaw 2014). Both sloughs are wet prairie habitats dominated by spikerush (primarily Eleocharis cellulosa) and large stocks of periphyton (Turner et al. 1999). Interspersed throughout these sloughs are alligator ponds which are generally deeper open water areas surrounded by dense and distinct communities of emergent vegetation (Palmer and Mazzotti 2004; previous chapter). The Everglades is marked by interannual variation in rainfall and distinct seasons where roughly $75 \%$ of the annual rainfall occurs May through October (Gaiser et al. 2012).

We sampled ten active alligator ponds with five each in Shark River Slough and Taylor Slough (Figure 1). Based on telemetry data from Strickland et al. (Chapter 3) and the restricted movement patterns of alligators in the marsh, all sites were at least 1,500 m apart to ensure that multiple ponds in the study were not maintained by the same alligator. There are three distinct habitats associated with alligator ponds (Palmer and Mazzotti 2004) extending outwards from the center of the pond: 1) a pool or semi-open water habitat (hereafter "pond"), 2) a dense ring of vegetation immediately surrounding the pond (hereafter "near-pond"), and 3) the adjacent marsh. Each site was sampled in November-December 2018 (high water period, referred to as "wet season") and MarchApril 2019 (low water period, referred to as “dry season”). 


\section{Field sampling}

For each pond, we took samples of flocculent detrital matter ("floc") in three different locations within each habitat and then aggregated into a single sample. Floc was obtained by taking a core with a $5 \mathrm{~cm}$ diameter piston corer and waiting approximately 3 min as the floc settled to the bottom of the aqueous layer following Noe et al. (2002). We removed the top water and then transferred all pourable floc into a sample container. Floc samples were immediately placed on ice and frozen until laboratory analysis. We also collected floating mat-forming and epiphytic mat-forming periphyton by filling a perforated 2,000 mL graduated cylinder with samples from multiple areas within a habitat, removing the water and placing directly in a container. In addition, all dominant emergent vascular plant species in each habitat at all sites were collected as a composite made of leaves or mid-stem from multiple individuals in multiple areas. We also collected aggregates of all dominant submerged non-vascular plants, namely Utricularia spp., and submerged vascular plants. All samples were identified then stored on ice until frozen in the laboratory.

We performed three $1 \mathrm{~m}^{2}$ throw trap samples in each habitat at each site ( 9 total throws per site). We were not able to sample at each habitat of every site and every visit because of the limitations of throw traps in cases where water depth was less than $5 \mathrm{~cm}$ or greater than $1 \mathrm{~m}$ or vegetation stem was density greater than 200 stems $\mathrm{m}^{2}$ (Jordan et al. 1997). In addition, we deployed five minnow traps in each habitat for approximately 4 hours. We also deployed omni-directional drift fences with minnow traps left overnight for two consecutive 24-hour periods with collection at each 24-hour period (Obaza et al. 2011). Two fences were deployed in the marsh and one fence was deployed in the near- 
pond habitat. Drift fences were not deployed in the pond because of ethical and logistical concerns of blocking alligator movement. All animals collected were euthanized with a lethal dose of MS-222 prior to being stored on ice. Animals were identified to species, counted, measured to the nearest $\mathrm{mm}$, weighed to the nearest $\mathrm{mg}$, and sexed when possible in the laboratory.

Fatty acid analyses

For every sample, material or tissue was freeze-dried, crushed, and weighed. Consumer samples were extracted from crushed whole-body samples following Schlacher et al. (2014) with physical removal of bone and large pieces after milling. We removed the digestive tracts of all consumers except Palaemonetes paludosus, which were too small to dissect. To get enough material for analyses, we created composite samples of six individuals of each target consumer and used floc and producer aggregates. We sent samples to Microbial ID Inc. (Newark, Delaware, USA) to perform fatty acid methyl esters (FAME) analyses using gas chromatography (Agilent 6890 GCFID column; Santa Clara, California, USA). We used the mass spectrometry total peak area divided by the dry weight of the sample as a proxy for total lipid content for comparing samples within this study. Tracing fatty acid biomarkers allowed us to determine the contribution of detritus and primary productivity to the food webs. Using the profiles, we estimated proportion of poly-unsaturated (PUFA) compared to monounsaturated (MUFA) and saturated fatty acids (SAFA). PUFAs are commonly from autotrophic (e.g., algal) sources whereas MUFAs and SAFAs generally originate from heterotrophic bacteria and fungi (see Belicka et al. 2012). 
We present fatty acids as $\mathrm{A}: \mathrm{B} \omega \mathrm{C}$, where $\mathrm{A}$ describes the number of carbon atoms, $\mathrm{B}$ is the number of double bonds, and $\mathrm{C}$, if needed, gives the location of the first double bond from the methyl end. We grouped PUFA (poly-unsaturated fatty acid), MUFA (mono-unsaturated fatty acid), and SAFA (saturated fatty acid). To reduce the noise in these relatively rough labels, we also used a literature search to associate particular fatty acids with bacterial, vascular plant, and algal sources (Table 1; Belicka et al. 2012; Dalsgaard et al. 2003; Napolitano 1999). We also identified several fatty acids and their precursors as essential for all vertebrates and probably all invertebrates given previous research in aquatic systems (see Parrish 2009) including: docosahexaenoic acid (DHA,

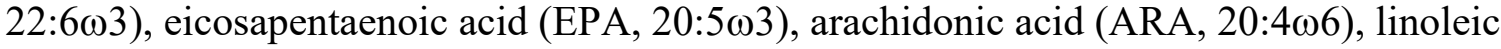

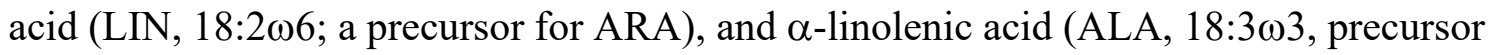
of EPA and DHA) (see Kainz et al. 2004). These $\omega 3$ and $\omega 6$ PUFAs are essential foundations for components of cell membranes and important for several cellular processes (Ahlgren et al. 2009). Algae can de novo synthesize these highly unsaturated fatty acids (HUFAs; $\geq 20 \mathrm{C}$ and $\geq 3$ double bonds) in large amounts whereas animals lack the enzymes needed to add double bonds to fatty acids closer than the $7^{\text {th }}$ carbon (Ahlgren et al. 2009).

\section{Statistical analyses}

We used multivariate analysis of variance (MANOVA) to test differences in means within source groups (i.e., algal, bacterial, and plant) across sloughs, seasons, and habitats. To meet the assumption of normality, we used arcsine-square-root transformation on proportions of total fatty acids. We compared the logit transformation 
using quantile plots. If an effect was significant, we then used post-hoc univariate analysis of variance to determine which group(s) were significant for the effect. We then were able to use post-hoc Tukey's Honest Significant Differences on each pairwise comparison of factor levels and calculate adjusted p-values for multiple comparisons.

To determine differences of individual essential fatty acids or total sum of essential fatty acids within sample types, we used an analysis of variance or repeated measures analysis of variance depending on the design. We log-10(x+1) transformed ratios of groups and fatty acids and used the same approach. We followed up significance with post-hoc Tukey's Honest Significant Differences. We performed all statistical analyses using R (Mac version 3.6.1; R Foundation for Statistical Computing; Vienna, Austria). We reported means with \pm 1 standard deviation (SD) and evaluated significance at $\alpha=0.05$.

\section{Results}

In 231 food-web samples, we detected 138 different fatty acids. We obtained fatty acid profiles detailing the percent composition of each fatty acid for composites of 18 plant species, 4 different organic matter sources (i.e., mat-forming periphyton, floc, and Nostoc colonies), and 20 consumer taxa across sites, habitats, and seasons. However, we were limited in comparisons across habitats, seasons, and sloughs for certain types of samples because of low sample sizes within groups. Typically, comparisons were only made when at least three composites existed within a slough in a given season at a specific habitat. 
In the floc, we detected 90 different fatty acids. We did not find EPA, DHA, or ALA in our floc samples. Mean ARA was $0.50 \pm 0.36 \%$ and occurred in only 3 of our 52 floc samples. Mean LIN was $1.05 \pm 0.59 \%$ from 45 samples. The sum of essential fatty acids averaged $0.9 \pm 0.7 \%$. PUFAs made up $11.7 \pm 3.7 \%$, MUFAs accounted for $27.8 \pm$ $5.5 \%$, and SAFAs were $60.5 \pm 6.3 \%$ of the total fatty acids. The most abundant fatty acids were 16:0 $(13.0 \pm 2.5 \%), 19: 1 \omega 6(9.6 \pm 5.0 \%)$, and 21:1 $155(5.8 \pm 2.7 \%)$. All other fatty acids averaged less than $5 \%$ of their individual total contribution. The floc layer did not exist in the near-pond habitats at Taylor Slough sites during the dry season because of the lack of water. MANOVA of fatty acids grouped by source only showed that habitat was significant (Figure 2; Table 2). Post-hoc tests revealed that algal and plant contributions varied across habitat but not bacterial sources (Table 3). Specifically, we saw that the comparison of marsh and pond algal contribution differed as well as plant contributions in the marsh versus near-pond and marsh and pond (Table 4). Pond had a higher mean algal contribution $(14.59 \pm 1.75 \%)$ compared to the marsh $(12.47 \pm 2.19 \%)$. Marsh had a higher mean plant contribution $(8.54 \pm 2.83 \%)$ than pond $(4.19 \pm 2.64 \%)$ or near-pond $(4.99 \pm 2.80 \%)$. After separating floc samples by season because of incomplete design, we did not see any significant factors for explaining differences in the sum of essential fatty acids or the percent total of LIN (Table 5). The ratio of saturated and unsaturated to poly-unsaturated fatty acids during the dry season varied among habitats $\left(\mathrm{F}_{2,19}=6.43, p=0.01\right)$. Specifically, marsh ratio was significantly higher $(\sim 63 \%$ larger $)$ than the near-pond (transformed $d=-0.19, p<0.01$ ) but not marsh and pond (transformed $d=-0.06, p=0.35$ ) or near-pond and pond (transformed $d=0.12, p=0.08$ ). 
We only found floating periphyton mats in the marsh habitats and once in a nearpond habitat (excluded in analyses). Floating periphyton mats were collected at eight marsh sites in the wet season and eight in the dry season between the two sloughs. Within floating mat samples we identified 80 fatty acids. We detected all our target essential fatty acids and their precursors across all samples, but all means were $\leq 1 \%$ total except LIN which averaged $7.1 \pm 1.2 \%$. DHA was not detected in the wet season. The sum of essential fatty acids averaged $9.3 \pm 2.3 \%$. The most abundant fatty acids were $16: 0$ (31.2 $\pm 3.7 \%)$ and $16: 1 \omega 7(10.5 \pm 1.9 \%)$. All other fatty acids averaged less than $10 \%$ of their individual total contribution. PUFAs made up $13.5 \pm 3.8 \%$, MUFAs accounted for $33.1 \pm$ $1.7 \%$, and SAFAs were $53.3 \pm 3.0 \%$ of the total fatty acids. MANOVA showed that fatty acids grouped by source varied only by slough and not by season (Figure 3; Table 6). Algal contributions were greater in Shark River Slough (mean $=30.6 \pm 3.4 \%)$ than Taylor Slough $\left(\right.$ mean $\left.=26.3 \pm 1.4 \% ; \mathrm{F}_{11.2}=3.5, p<0.01\right)$. Bacterial and plant sources did not differ (Table 7). EPA, ALA, and DHA were not present in enough samples to compare between seasons or sloughs. There were no significant differences among treatments in of our other fatty acid response variables (Table 8).

Periphyton epiphytic mats were collected at primarily marsh sites, but were also present at one near-pond and two pond sites. Eight of ten marsh sites had epiphytic mats (three in Shark River Slough) in the wet season, but it was present at only two sites in the dry season. Because of these low sample sizes, we did not run models comparing fatty acids and composition. For the marsh sites in the wet season, we identified 48 fatty acids with 16:0 (32.9 $\pm 2.7 \%)$ and 16:1 $\omega 7(10.2 \pm 2.1 \%)$ being the most abundant. Similarly, to 
the floating mats, PUFAs made up $16.0 \pm 2.3 \%$, MUFAs accounted for $33.5 \pm 2.7 \%$, and SAFAs were $50.4 \pm 3.7 \%$ of the total fatty acids. In these samples, we found all essential fatty acids averaged less than $2 \%$ except LIN which averaged $8.4 \pm 1.4 \%$. The sum of essential fatty acids averaged $8.6 \pm 2.5 \%$. We did not find a difference in source contributions between floating and epiphytic mats within a site (Pillai $=0.85$, approximated $\mathrm{F}_{3,3}=5.6, p=0.09$ ).

We sampled 18 species of vascular plants across the three habitats at multiple sites (Table A1). However, only one composite of each species was processed, and the associated habitat with that sample was arbitrarily chosen. This prohibited comparisons across our study design including habitat, slough, and season. We are only able to describe the relative importance of different fatty acids. Only two plants contained DHA. Utricularia purpurea and Potamogeton illinoensis collected in the marsh had $0.4 \%$ and $1.3 \%$, respectively. Only five plants (Utricularia purpurea, Panicum hemitonum, and Utricularia foliosa in marsh; Nuphar advena in ponds; Hymenocallis latifolia nearponds) had EPA, but at less than $0.4 \%$ of total fatty acids. ARA was only in U. purpurea in the marsh $(0.7 \%$ of total fatty acids). ALA was abundant in all plants (mean $=31.3 \pm$ $9.7 \% ; \min =7.2 \%, \max =45.1 \%)$ as was $\operatorname{LIN}(\operatorname{mean}=15.2 \pm 6.2 \% ; \min =5.9 \%, \max =$ 28.7). Surprisingly, plant markers for source contributions $(1.7 \pm 1.5 \%)$ were relatively low compared to bacterial $(5.6 \pm 1.7 \%)$ and algal markers $(52.1 \pm 9.4 \%)$. Sum of essential fatty acids and their precursors were very high $(46.3 \pm 11.9 \%)$ relative to floc and periphyton mats. The most abundant fatty acids were ALA, 16:0 (21.3 $\pm 4.2 \%)$, and LIN. All other fatty acids averaged less than $7 \%$ of the total fatty acids. 
Bluefin Killifish (Lucania goodei) samples contained 78 fatty acids with 16:0 (22.1 $\pm 1.4 \%), 18: 1 \omega 9(14.1 \pm 1.7 \%)$, and 18:0 (10.9 $\pm 2.2 \%)$ being the most abundant. All other fatty acids contributed less than $8 \%$ individually. All individuals had DHA (3.2 $\pm 0.9 \%)$, EPA $(0.6 \pm 0.2 \%)$, ARA $(5.1 \pm 0.9 \%)$, and LIN $(6.8 \pm 1.3 \%)$. We only detected ALA in three animals, which were all in the marsh. EPA:DHA averaged $0.2 \pm 0.1 \%$ and DHA:ARA averaged $0.6 \pm 0.1 \%$. Of our 24 Bluefin Killifish samples, we removed two near-pond samples and six dry season samples because of a lack of paired samples at a specific site. We compared marsh and pond habitats in the wet season using 14 paired samples from seven sites. We did not find a difference in source contributions between marsh and pond habitats within a site (Figure 4, Pillai $=0.74$, approximated $\mathrm{F}_{3,4}=3.7, p$ $=0.12)$. Percentages of EPA $\left(\mathrm{F}_{1,6}=5.1, p=0.06\right)$, DHA $\left(\mathrm{F}_{1,6}=0.1, p=0.72\right)$, and ARA $\left(\mathrm{F}_{1,6}=3.6, p=0.11\right)$ were not different among habitats. However, LIN was lower in ponds $($ mean $=5.9 \pm 1.0 \%)$ than marshes $\left(\right.$ mean $\left.=8.4 \pm 0.8 \% ; \mathrm{F}_{1,6}=57.4, p<0.01\right)$. Ratios of fatty acids were not affected by habitat.

Eastern Mosquitofish (Gambusia holbrooki) samples had 59 fatty acids with 16:0 (24.8 $\pm 2.2 \%), 18: 1 \omega 9(19.1 \pm 3.3 \%)$, and 18:0 $(10.8 \pm 1.7 \%)$ as the most abundant and others contributing less than $8 \%$ individually to the total. All individuals contained DHA $(3.5 \pm 1.5 \%)$, ARA $(4.7 \pm 1.9 \%)$, and $\operatorname{LIN}(7.5 \pm 1.6 \%)$; all except one in the pond for the wet season had detectable EPA $(0.5 \pm 0.2 \%)$. None had ALA. EPA:DHA averaged $0.1 \pm$ $0.1 \%$ and DHA:ARA averaged $0.7 \pm 0.1 \%$. Of the 17 Eastern Mosquitofish samples, we were only able to compare eight paired marsh and pond samples in the wet season and six paired pond samples across the wet and dry season. There was no difference in source 
contribution between habitats in the wet season (Figure 4, Pillai $=0.95$, approximated $F_{3,1}$ $=6.7, p=0.27)$. Percentages of EPA $\left(\mathrm{F}_{1,3}=4.6, p=0.12\right)$, DHA $\left(\mathrm{F}_{1,3}=1.8, p=0.28\right)$, $\operatorname{ARA}\left(\mathrm{F}_{1,3}=3.0, p=0.18\right)$, and $\operatorname{LIN}\left(\mathrm{F}_{1,3}=7.0, p=0.08\right)$ were not different among habitats in the wet season. Ratios of fatty acids were not affected by habitat. Percentages of EPA $\left(\mathrm{F}_{1,2}=0.04, p=0.86\right), \operatorname{DHA}\left(\mathrm{F}_{1,2}=0.1, p=0.84\right), \operatorname{ARA}\left(\mathrm{F}_{1,2}=0.4, p=0.58\right)$, and LIN $\left(\mathrm{F}_{1,2}=0.7, p=0.49\right)$ were not different between seasons within the pond. Ratios of fatty acids were not affected by season either.

There were 53 fatty acids within grass shrimp (Palaemonetes paludosus) samples. Again, 16:0 (19.1 $\pm 1.6 \%), 18: 1 \omega 9(14.9 \pm 1.5 \%)$, and 18:1 $1 \omega 7(10.6 \pm 1.1 \%)$ were the most abundant and others contributed less than $9 \%$ individually to the total. All samples had DHA $(1.5 \pm 0.5 \%)$, EPA $(5.5 \pm 1.3 \%), \operatorname{LIN}(7.9 \pm 1.1 \%)$, and ARA $(7.3 \pm 1.0 \%)$ none had ALA. Of the 25 grass shrimp samples, we compared 12 paired marsh samples between seasons and eight wet season samples across marsh and near-pond. There was also no difference in source contribution between seasons in the marsh habitat (Pillai $=$ 0.89 , approximated $\mathrm{F}_{3,3}=8.0, p=0.06$ ). Though bacterial contributions differed the most averaging $17.3 \pm 0.9 \%$ in the wet season compared to $15.7 \pm 1.0 \%$ in the dry season. Percentages of EPA $\left(\mathrm{F}_{1,5}=0.65, p=0.46\right), \operatorname{DHA}\left(\mathrm{F}_{1,5}=5.2, p=0.07\right), \operatorname{ARA}\left(\mathrm{F}_{1,5}=4.4, p\right.$ $=0.09)$, and $\operatorname{LIN}\left(\mathrm{F}_{1,5}=0.8, p=0.41\right)$ were not different between seasons within the marsh. Both EPA:DHA $\left(\mathrm{F}_{1,5}=15.0, p=0.01\right)$ and DHA:ARA $\left(\mathrm{F}_{1,5}=21.6, p<0.01\right)$ had differences explained by seasons in the marsh. Untransformed DHA:ARA averaged 0.18 \pm 0.02 in the wet season and was higher in the dry season $\left(0.27 \pm 0.04 ; \mathrm{F}_{7.8}=-4.4, p<\right.$ 0.01). Untransformed EPA:DHA averaged $3.96 \pm 0.64$ in the wet season and $3.23 \pm 0.80$ in the dry season; the difference was not significant post hoc $\left(\mathrm{F}_{9.1}=1.9, p=0.10\right)$. There 
was no difference in source contribution in the marsh and near-pond habitats during the wet season $\left(\right.$ Pillai $=0.96$, approximated $\left.\mathrm{F}_{3,1}=7.4, p=0.26\right)$. Percentages of DHA $\left(\mathrm{F}_{1,3}=\right.$ $5.4, p=0.10), \operatorname{ARA}\left(\mathrm{F}_{1,3}=2.3, p=0.23\right)$, and $\operatorname{LIN}\left(\mathrm{F}_{1,3}=2.9, p=0.19\right)$ were not different among habitats in the wet season. EPA averaged $5.3 \pm 0.5 \%$ in the marsh and $4.8 \pm 0.7 \%$ in the near-pond and did differ $\left(F_{1,3}=16.0, p=0.03\right)$. However, conservative post hoc tests did not reveal a difference $\left(\mathrm{F}_{5.6}=1.2, p=0.29\right)$. Ratios of fatty acids were not affected by habitat.

\section{Discussion}

Trophic structure has been found to be different among habitats associated with alligator ponds for both vascular plant and aquatic consumer communities (Chapter 4; Palmer and Mazzotti 2004). Thus, these habitats may have distinct food-web compartments, though little is known about their connectivity in energy flow. Given evidence of phosphorus enrichment of alligator ponds (Chapter 4), these nutrient hotspots may have enhanced nutrient availability for algae and other producers. Our findings reveal that indeed the flocculent detrital layer in the ponds engineered by alligators had a higher proportion of algal-derived fatty acids than the marsh. These results indicate a potential shift in energy flow towards algal production associated with alligator engineering activities. Though these findings are largely descriptive, future experimental approaches may be able to partition the exact mechanisms for these observed shifts in energy flow. Three species of abundant and ubiquitous consumers found across the pondmarsh interface relied on both detrital and algal routes to meet nutritional demands. Little is known about the movements of these animals, but they may be an important link in 
trophic connectivity across a P-enriched "green" food web compartment in alligator ponds and the oligotrophic marsh "brown" food web.

\section{Basal resources}

We found the highest quantities of total fatty acids indicative of bacterial sources in our floc as expected compared to periphyton and consumers. We also found the most long-chain carbon vascular plant signatures in the floc as well. The flocculent detrital layer sits just above sediment and is primarily composed of decaying algae, vascular plants, and the remains of aquatic consumers (Neto et al. 2006). We found similar amounts of PUFA in floc as in periphyton sources. Much of the periphyton is not directly consumed by grazers (Geddes and Trexler 2003; Sanchez and Trexler 2018). This material eventually decays and moves into the floc layer providing PUFAs to the detritus. Potentially, these PUFAs remain largely undegraded in the Everglades explaining their large presence in floc. In the decomposition process, fatty acids and total fatty acid composition may undergo changes from their presence in living tissue largely because of changes brought by exposure to bacterial enzymes (Notter et al. 2009). The degree of changes can be species-specific and largely depends on the abiotic conditions of decomposition (Mfilinge et al. 2003; Notter et al. 2009). Studying mangrove leaf decomposition in Japan, Mfilinge et al. (2003) found a change in two weeks from mainly saturated fatty acids to monounsaturated and then to branched fatty acids. Interestingly, even though PUFAs are suspected to be more labile than SAFA or MUFA (see Harvey and Macko 1997; Carrie et al. 1998), Mfilinge et al. (2003) did not find degraded PUFAs even after four months. 
Detritus and the flocculent detrital layer may be the dominant source of carbon flow in the oligotrophic Everglades freshwater marsh (Williams and Trexler 2006). Indeed, we observed fatty acids indicative of bacterial and detrital sources in all three of our consumers. However, floc did not contain many essential fatty acids or their precursors meaning that vertebrate and probably invertebrate detritivores need to supplement their diets with fresh algae beyond eating detritus and associated saprophytes. The microbial community attached to floc, including heterotrophic nanoflagellates and protozoans, can biosynthesize PUFAs and produce precursors to fatty acids (Anderson et al. 2017; Bec et al. 2006; Klien Breteler et al. 1999). Also, the freshwater rotifer and heterotrophic Euglenida also can use pathways to transform PUFAs to essential fatty acids like EPA and ARA (Meyer et al. 2003; Wallis and Browse 1999; Lubzens et al. 1985). Regardless, biosynthesis of long-chain PUFAs is suspected to be rare and unlikely for higher trophic levels like zooplankton and fish and they must receive these essential fatty acids by diet (Tocher 2003). Thus, consumption of fresh algal material may be a critical component for detritivores in meeting their nutritional demands.

As expected, pond habitats had a higher mean algal contribution compared to the marsh in the floc. This follows the prediction for our hypothesis that ponds are shifted towards greater primary production because of nutrient enrichment from alligator engineering activities. Our model did not show that season was an important explanatory variable in these contributions. Even though immediate enrichment of the pond may occur in the dry season from the concentration of biological activity in alligator ponds, there is a lag in productivity and turnover of tissue (decomposition) into the floc. Also, the abiotic conditions within the dry season may lead to an increase in dead and decaying 
material associated with plant and algal loss and eventually drive an increase in saprophytes. Future studies may be able to unravel the complexities of these interactions by sampling basal resources multiple time points between seasons along with detailed microbial surveys. We also found that marsh habitats had a higher mean plant contribution than pond or near-pond. Organic matter from vascular plants may be largely integrated back into the food web by decomposition and incorporation into the floc layer as detritus given the lack of "true" plant herbivores (Williams and Trexler 2006; Sanchez and Trexler 2018). The near-pond habitat was certainly the most vegetation dense habitat; however, there may be differences in plant turnover rates and decomposition in the marsh. As expected, the pond had the lowest vascular plant contribution given the lack of plants within the deep-water basins that alligators maintain.

Mat-forming periphyton were common in the marsh, and largely absent from the near-pond and pond habitats (see previous chapter). We hypothesize that the lack of periphyton is related to higher nutrient enrichment in the alligator engineered habitats because periphyton mats generally break apart when P-loading exceeds $10 \mu \mathrm{g} \mathrm{L}^{-1}$ (Gasier et al. 2005; Gasier 2009). We saw contributions of all three sources (algae, plants, and bacteria) in our periphyton samples. Periphyton communities include algae, bacteria, cyanobacteria, fungi, detrital particulate matter and often calcium carbonate usually attached to live and decaying submerged macrophytes (Cleckner et al. 1999). These coupled autotrophic and heterotrophic microbial assemblages are generally net autotrophic (Iwaniec et al. 2006). Indeed, fatty acid contributions from algal sources were more than double that of bacteria and 17 times higher than plant sources. In the freshwater Everglades, periphyton is an important basal food resource and is directly or 
indirectly consumed by many aquatic fauna including invertebrates and small fish (Williams and Trexler 2006; Geddes and Trexler 2003). In fact, in the Everglades, periphyton is thought to be responsible for more than half of the primary production (Ewe et al. 2006). We found that periphyton mats contained all target essential fatty acids and precursors. These PUFAs are transferred from autotrophs by diet and accumulate in higher trophic levels. EFAs are important in fish and invertebrate diets by sustaining cell membrane fluidity (Pruitt 1990) and hormonal stability (Bell et al. 1991). Like many wetlands, the Everglades freshwater marsh, lacks abundant phytoplankton assemblages in the water column; thus, most algae are a part of periphyton layers (Goldsborough and Robinson 1996; McCormick et al. 1997). Given this fact and that algae are the only source for biosynthesizing PUFAs in abundance, periphyton may be the most important source of essential fatty acids in the Everglades freshwater food web. However, work shows that periphyton communities have a range of edibility (Geddes and Trexler 2003) affecting the transferal of macronutrients like fatty acids to grazers. The additional proportion of algal markers in the pond habitat is perhaps related not to production of mats, which are not found in the pond, but instead to the growth of benthic periphyton or potentially phytoplankton in the water column. Future studies may be able to more thoroughly sample algal communities across alligator pond associated habitats.

There has been considerable work looking at the fatty acid composition of primary producers. For instance, temperature, availability of nutrients, and light levels impact the fatty acid composition of primary producers (Harwood and Guschina 2009). In general, under nutrient-limited conditions algae reduce the proportion of PUFAs and increase storage lipid content of their cells primarily in the form of nonpolar 
triacylglycerols usually SAFAs and MUFAs (Lynn et al. 2000; Poerschmann et al. 2004). We found that algal contributions in periphyton mats for Taylor Slough were lower compared to Shark River Slough. Taylor Slough in general is drier and has a shorter hydroperiod than Shark River Slough (Kotun and Renshaw 2014). In marl prairies, short hydroperiods are associated with a loss of green algae and diatoms in periphyton (Gottlieb et al. 2005). Water management and the resultant reductions in hydroperiod across the Everglades has likely decreased annual periphyton production (Gaiser et al. 2011). Future work could couple microbial and algal surveys along with tracing fatty acid markers between seasons and areas of varying hydrological regimes. Understanding how hydrology impacts the route of energy and organic matter in aquatic food webs is a crucial piece of information for restoration efforts.

Vascular plants sampled across the study design contained high abundances of ALA and LIN compared to periphyton and floc. The abundance of these precursors drove the sum total of essential fatty acids to be much higher in plants. Therefore, vascular plants may be good sources of fatty acid nutrition for herbivores. However, vascular plants, even submerged ones, are rare in the diets of Everglades aquatic fauna except by accidental grazing (Belicka et al. 2012). Little is known about why animals do not generally take advantage of abundant vascular plant resources in wetlands (see Sanchez and Trexler 2018). Essential fatty acid precursors from plants including LIN and ALA may be primarily integrated into the food web by decomposition in floc as detritus. In addition, researchers are still discovering the importance of total essential fatty acids in animal food sources. For example, the sum of ARA, EPA, and DHA were correlated to mussel (Mytilus edulis) growth, but separately they did not affect growth (Alkanani et al. 
2007). Clearly, the role of fatty acids is complicated and is species- and individualspecific with regards to antecedent nutrition, physiological conditions, and needs for growth and reproduction (Nelson 1992). Surprisingly, plant markers were low in our plant samples compared to bacterial and algal markers. Even though all plants were rinsed with deionized water before processing, algal and bacterial films likely coated the exterior of the plant. However, we are doubtful that this would explain the totality of the differences. Eglinton and Hamilton (1967) found that these unique long-chain fatty acids, which we used as our biomarkers, are mainly present in the epicuticular wax layer of higher plants. However, they may be in relatively low abundance compared to other fatty acids. In fact, production in abundance may be related to stressful environmental conditions such as heavy metal exposure and hypoxia (see De Bigault Du Granrut and Cacas 2016). Given the low abundance of these long-chain fatty acids in aquatic macrophyte tissues, fatty acid analyses in future studies could be combined with experimental diet studies and other chemical techniques like stable isotopes.

\section{Aquatic consumers}

Across the study we detected 16:0 (palmitic acid) in abundance including in the floc and periphyton. This is not surprising given that it may be the most abundant fatty acid in nature (Christie and Han 1996). For instance, it comprises 20-30\% of the total fatty acids in the human body (Carta et al. 2017). Saturated and monounsaturated $\mathrm{C}_{18}$ length fatty acids were also common in our three consumer species. In addition to 16:0, 18:0 (stearic acid) is highly abundant in animal tissue (Christie and Han 1996). Pathways exist for all animals to elongate and desaturate several saturated fatty acids (14:0, 16:0, 
and 18:0) to create their monounsaturated isomers $(14: 1 \omega 5,16: 1 \omega 7$, and 18:1 $\omega 9)$

(Iverson 2009). However, the ability to do this is likely dependent on having abundant fat and long-chain PUFA (Nelson 1992). Even though it may be relatively rare and contextdependent, the potential influence of de novo synthesis of essential fatty acids (mainly precursors) by aquatic consumers has not been well-considered in food-web studies (Tocher 2003). For instance, LIN and ALA may also be converted to DHA and ARA as observed in Arctic Charr (Salvelinus alpinus) and Rainbow Trout (Oncorhynchus mykiss) (Yang and Dick 1994). The same desaturases are needed for the conversions of ALA and LIN to EPA and ARA as well as the conversion of EPA to DHA resulting in competition between different n-3 and n-6 PUFAs and the need to consider proportions (Sargent et al. 1997). Regardless, biosynthesis of HUFAs is suspected to be rare and unlikely for higher trophic levels like zooplankton and fish, which must receive these essential FAs by diets (Tocher 2003).

Our three consumers are some of the most abundant and highest biomass freshwater consumers in the Everglades and were readily found in all three habitats. For instance, grass shrimp made up $61 \%$ of the invertebrate biomass across the freshwater Everglades and the Bluefin Killifish and the Eastern Mosquitofish standing crops were in the top three for fishes (Turner et al. 1999). In our study, all three consumers had large proportions of algal contributions (roughly double that of bacterial) and very low vascular plant markers. Belicka et al. (2012) similarly found that most consumers had low proportions of vascular plant markers. We saw little evidence of vascular plant grazing for any of our consumers even though grass shrimp are thought to primarily feed on algae, vascular plants, detritus, and insects in this order (Beck and Cowell 1976). Thus, 
vascular plants may not be a main source of direct energy and instead may contribute energy through detrital pathways in the Everglades food web (Belicka et al. 2012; Williams and Trexler 2006). In the Everglades, the grass shrimp and the Eastern Mosquitofish are considered omnivores, primarily consuming algae and small invertebrates living in periphyton (Geddes and Trexler 2003). Williams and Trexler (2006) hypothesized that Eastern Mosquitofish and grass shrimp may feed in different food web compartments; Eastern Mosquitofish feed in the water column and near the surface, while grass shrimp are benthic consumers. We found that the proportion of source contributions and specific fatty acids reveal that grass shrimp and Eastern Mosquitofish feed on both algae and detritus. Contrary to predictions of Williams and Trexler (2006), grass shrimp total fatty acids exhibited the highest bacterial contributions, especially compared to the Eastern Mosquitofish. Grass shrimp also had 9-11 times the mean percent total fatty acid amount of EPA, a marker for diatoms (Napolitano 1999; Dalsgaard et al. 2003), compared to Eastern Mosquitofish and Bluefin Killifish. Such high levels of this particular fatty acid in grass shrimp, also supported by Belicka et al. (2012), indicates potential direct feeding on diatoms or on prey that specialize in diatom grazing. The Bluefin Killifish had higher bacterial contributions than the Eastern Mosquitofish. Bluefin Killifish are thought to be mostly carnivores feeding on small invertebrates and direct detritivory or herbivory has not been documented (Loftus and Kushlan 1987; Taylor et al. 2001). The fatty acid markers for all three sources are expected to remain relatively unmodified in trophic transfer; thus, the Bluefin Killifish may be accumulating detrital fatty acids from prey by eating detritivores and benthic invertebrates with high bacterial contributions. Overall, we found both algal and bacterial 
sources may be important routes of energy and macronutrients for all three consumers. Whether these markers are obtained indirectly through prey diets or directly through consumption of algae and detritus in the periphyton or floc layer is unclear.

Overall, habitat did not explain differences in fatty acid source contributions from algae, bacteria, or plants across our three consumers. The composition of fatty acids in a particular aquatic consumer may depend on prey availability, physiology, and the general taxonomic structure of the food web (Kainz and Fisk 2009). In addition, animal movement between habitats may trophically connect two functionally different assemblages of species and food-web compartments (Polis et al. 1997). Even though the movement rates of many small wetland fishes and invertebrates have not been wellstudied, dispersal capabilities for several species are thought to be high given their ability to be found quite ubiquitously in ephemeral wetlands. For instance, the Eastern Mosquitofish is thought to be an excellent disperser (Goss et al. 2014; Ruetz et al. 2005) and is even invasive in some areas (Rehage and Sih 2004). Our consumers may be relatively mobile compared to the local habitats we compared within this study and may trophically connect marsh, near-pond, and pond habitats. The apparent lack of differences of the source of organic matter between distinct habitats may indicate their trophic connectivity. We encourage future work in wetland ecosystems to understand the movement rates and the potential food web effects of cross-habitat movements especially across gradients of nutrient availability.

Dry season sampling was relatively sparse prohibiting comparisons between seasons. For the Eastern Mosquitofish, we did not see a difference in contributions between seasons for the pond habitat. This is interesting because the trophic position of 
the Eastern Mosquitofish has a strong seasonal component (Williams and Trexler 2006). Williams and Trexler (2006) found at oligotrophic freshwater marsh sites that both grass shrimp and Eastern Mosquitofish showed increasing trophic position with increasing time after drying (Williams and Trexler 2006). The exact mechanism is unclear, but it was hypothesized that droughts act as environmental filters by reducing the movements of large predatory fish thus compacting food chain length (Williams and Trexler 2006). For Eastern Mosquitofish, we only had enough composite samples to compare animals in the pond habitat between seasons. The alligator pond sites we sampled stay wet year-round thus we hypothesize that drought may not act as a filter in the ponds. However, future studies may be able to determine how the concentration of large predators in the ponds during the dry season may change the landscape of fear and thus the foraging behavior and fatty acid composition of smaller fish.

ALA was quite rare across all three consumers. ALA in most cases is thought to be essential in aquatic fauna because of its role as a precursor (Parrish 2009). Indeed, ALA may be quickly converted to other essential fatty acids (Sargent et al. 1997; Yang and Dick 1994). Evidence also indicates that both LIN and ALA are less efficiently retained in aquatic food webs than other essential fatty acids because of their conversion to ARA and EPA, respectively (Kainz et al. 2004). Ratios of $\omega 3$ and $\omega 6$ PUFA are important because of competition among different essential fatty acids and their precursors for conversion desaturases (Sargent et al. 1997). Interestingly, we did find for the grass shrimp that DHA:ARA was higher in the dry season compared to the wet season in marsh habitats. The DHA:ARA ratio may be an important dietary consideration, particularly for carnivorous animals that lack the enzymes needed to 
convert ALA to DHA and LIN to ARA (Ahlgren et al. 2009). Ratios of $\omega 3: \omega 6$ PUFA were higher in eutrophic conditions in a study of 20 Swedish freshwater sites across 130 freshwater fish with increased food supply and quality being the hypothesized driver (Ahlgren et al. 2009). The DHA:ARA ratios for Eastern Mosquitofish and Bluefin Killifish were higher meaning that they may be closer to an optimum (Ahlgren et al. 2009). The EPA:DHA ratio was 19 times higher for the grass shrimp compared to either fish species. In fact, these ratios were relatively low for the fish compared to what is expected to be the optimum-1 EPA:2 DHA for finfish (Bell et al. 2003) and maybe invertebrates (Arendt et al. 2005).

\section{Conclusion}

Both algal and bacterial sources are important routes of energy and macronutrients for all three consumers, but it is unclear whether these markers are obtained through prey or direct feeding in floc or periphyton. Sources were not different across consumers collected in the marsh, near-pond, and pond, but we hypothesize that these distinct habitats may be trophically connected by animal movement or some other mechanism. We did not find essential fatty acids in floc but found them in abundance in periphyton. Given the general lack of phytoplankton in the water column, periphyton may be a critical source of essential fatty acids even for benthic detritivores (Goldsborough and Robinson 1996). While vascular plants may have high essential fatty acid precursors, they may be primarily integrated into the food web by decomposition in floc as detritus rather than direct feeding. 
In the floc detrital layer, we did find that pond habitats had higher proportions of algal contributions compared to the marsh. Wetland food webs exist with a continuum of both detrital and algal energy channels. Our findings may be evidence of alligators not only engineering habitats that are nutrient enriched (Chapter 4), with different plant and consumer communities (Chapter 4), but also habitats with dissimilarities in overall ecosystem function seen by changes in the origin of organic matter and shifted energy channels toward primary production by algae. To further understand the role of both green and brown energy channels in wetland food webs, a promising avenue of research would be a focus on integrating nutrient cycling and the players that change these cycles (Zou et al. 2016). In experimental settings, fatty acid analyses could be paired with stoichiometric and stable isotope analyses to help understand the links of predators and ecosystem engineers, like alligators, in influencing ecosystem functioning.

\section{Acknowledgements}

This work was funded by Everglades National Park Task Agreement P18AC01074 under the Master Cooperative Agreement P18AC01074. The project was also supported by the National Science Foundation through the Florida Coastal Everglades Long-Term Ecological Research program under Grant \#DEB-1237517. We are grateful to many field and lab volunteers that assisted with this project especially Peter Flood and Joel Trexler. We thank Katherine Strickland for providing help for figures and tables. BAS was supported by the University Graduate School and Department of Biological Sciences assistantships at Florida International University as well as an Everglades Foundation fellowship. Research and animal procedures were 
conducted under the auspices of protocol \#IACUC-18-067-CR01 from the Institutional Animal Care and Use Committee of the University of Florida and in accordance with scientific research permit \#EVER-2017-SCI-0060 authorized by Everglades National Park and scientific collector's permits \#S-18-06 and \#S-19-05 granted by Florida Fish and Wildlife Conservation Commission.

\section{Literature Cited}

Ahlgren G, Gustafsson IB, Boberg M (1992) Fatty-acid content and chemical composition of fresh-water microalgae. Journal of Phycology 28:37-50

Ahlgren, G., Vrede, T., \& Goedkoop, W. (2009). Fatty acid ratios in freshwater fish, zooplankton and zoobenthos-are there specific optima? In Lipids in aquatic ecosystems (pp. 147-178). Springer, New York, NY.

Alkanani, T., Parrish C.C., Thompson, R.J., and McKenzie C.H. 2007. Role of fatty acids in cultured mussels, Mytilus edulis, grown in Notre Dame Bay, Newfoundland. J. Exp. Mar. Biol. Ecol. 348:33-45.

Anderson, T. R., Pond, D. W., \& Mayor, D. J. (2017). The role of microbes in the nutrition of detritivorous invertebrates: a stoichiometric analysis. Frontiers in microbiology, 7, 2113.

Arendt, K.E., Jonasdottir, S.H., Hansen, P.J., and Gartner, S. 2005. Effects of dietary fatty acids on the reproductive success of the calanoid copepod Temora longicornis. Mar. Biol. 146:513-530.

Bec, A., Martin-Creuzburg, D., and von Elert, E. 2006. Trophic upgrading of autotrophic picoplankton by the heterotrophic nanoflagellate Paraphysomonas sp. Limnol. Oceanogr. 51:1699-1707.

Beck, J. T., \& Cowell, B. C. (1976). Life history and ecology of the freshwater caridean shrimp, Palaemonetes paludosus (Gibbes). American Midland Naturalist, 52-65.

Belicka, L. L., E. R. Sokol, M. J. Hoch, R. Jaffé, and J. C. Trexler. 2012. A molecular and stable isotopic approach to investigate algal and detrital energy pathways in a freshwater marsh. Wetlands 32:531-542. 
Bell, J. G., McVicar, A. H., Park, M. T., \& Sargent, J. R. (1991). High dietary linoleic acid affects the fatty acid compositions of individual phospholipids from tissues of Atlantic salmon (Salmo salar): association with stress susceptibility and cardiac lesion. The Journal of nutrition, 121(8), 1163-1172.

Bell, J.G., McEvoy, L.A., Estevez, A., Shields, R.J., and Sargent, J.R. 2003. Optimising lipid nutrition in first-feeding flatfish larvae. Aquaculture 227: 211-220.

Campbell, M. R., and F. J. Mazzotti. 2004. Characterization of natural and artificial alligator holes. Southeastern Naturalist 3:583-594.

Carrie RH, Mitchell L, Black KD (1998) Fatty acids in surface sediment at the Hebridean shelf edge, west of Scotland.Org Geochem 29:1583-1593.

Carta, G., Murru, E., Banni, S., \& Manca, C. (2017). Palmitic acid: physiological role, metabolism and nutritional implications. Frontiers in physiology, 8, 902.

Christie, W. W., \& Han, X. (1996). Lipid analysis. Trends in Food Science \& Technology, 11(7), 145.

Cleckner, L. B., Gilmour, C. C., Hurley, J. P., \& Krabbenhoft, D. P. (1999). Mercury methylation in periphyton of the Florida Everglades. Limnology and Oceanography, 44(7), 1815-1825.

Cranwell PA, Jaworski GHM, Bickley HM (1990) Hydrocarbons, sterols, esters, and fatty acids in 6 fresh-water chlorophytes. Phytochemistry 29:145-151

Dalsgaard, J., St John, M., Kattner, G., Müller-Navarra, D.C., and Hagen, W. 2003. Fatty acid trophic markers in the pelagic marine environment. Adv. Mar. Biol. 46:225340 .

DeAngelis, D. L., L. J. Gross, M. A. Huston, W. F. Wolff, D. M. Fleming, E. J. Comiskey, and S. M. Sylvester. 1998. Landscape modeling for everglades ecosystem restoration. Ecosystems 1:64-75.

De Bigault Du Granrut, A., \& Cacas, J. L. (2016). How very-long-chain fatty acids could signal stressful conditions in plants?. Frontiers in plant science, 7, 1490.

Eglinton G, Hamilton RJ (1967) Leaf epicuticular waxes. Science 156:1322-1334

Elser, J. J., and J. Urabe. 1999. The stoichiometry of consumer-driven nutrient recycling: theory, observations, and consequences. Ecology 80:735-751. 
Ewe, S. M., Gaiser, E. E., Childers, D. L., Iwaniec, D., Rivera-Monroy, V. H., \& Twilley, R. R. (2006). Spatial and temporal patterns of aboveground net primary productivity (ANPP) along two freshwater-estuarine transects in the Florida Coastal Everglades. Hydrobiologia, 569(1), 459-474.

Findlay RH, Dobbs FC (1993) Quantitative description of microbial communities using lipid analysis. In: Kemp PF, Sherr BF, Sherr EB, Cole JJ (eds) Handbook of methods in aquatic microbial ecology. Lewis Publishers, Boca Raton.

Flecker, A. S., B. W. Taylor, E. S. Bernhardt, J. M. Hood, W. K. Cornwell, S. R. Cassatt, M. J. Vanni, and N. S. Altman. 2002. Interactions between herbivorous fishes and limiting nutrients in a tropical stream ecosystem. Ecology 83:1831-1844.

Heymans, J. J., R. E. Ulanowicz, and C. Bondavalli. 2002. Network analysis of the South Florida Everglades graminoid marches and comparison with nearby cypress ecosystems. Ecological Modelling 149:5-23.

Gaiser, E. (2009). Periphyton as an indicator of restoration in the Florida Everglades. Ecological Indicators, 9(6), S37-S45.

Gaiser, E. E., J. C. Trexler, J. H. Richards, D. L. Childers, D. Lee, A. L. Edwards, L. J. Scinto, K. Jayachandran, G. B. Noe, and R. D. Jones. 2005. Cascading ecological effects of low-level phosphorus enrichment in the Florida everglades. Journal of Environmental Quality 34:717-23.

Gaiser, E. E., McCormick, P. V., Hagerthey, S. E., \& Gottlieb, A. D. (2011). Landscape patterns of periphyton in the Florida Everglades. Critical Reviews in Environmental Science and Technology, 41(S1), 92-120.

Gaiser, E. E., J. C. Trexler, and P. R. Wetzel. 2012. The Florida Everglades in Batzer, D. P., and A. H. Baldwin. eds., Wetland Habitats of North America: Ecology and Conservation Concerns. Berkeley: University of California Press.

Geddes, P. \& J. C. Trexler, 2003. Uncoupling of omnivore- mediated positive and negative effects on periphyton mats. Oecologia 136: 585-595.

Goldsborough, L. G. \& G. G. C. Robinson, 1996. Pattern in wetlands. In R. J. Stevenson, M. L. Bothwell \& R. L. Lowe (eds), Algal Ecology: Freshwater Benthic Ecosystems. Academic Press, New York: 77-117.

Goss, C. W., Loftus, W. F., \& Trexler, J. C. (2014). Seasonal fish dispersal in ephemeral wetlands of the Florida Everglades. Wetlands, 34(1), 147-157. 
Gottlieb, A., Richards, J., \& Gaiser, E. (2005). Effects of desiccation duration on the community structure and nutrient retention of short and long-hydroperiod Everglades periphyton mats. Aquatic Botany, 82(2), 99-112.

Hart, E. A., \& Lovvorn, J. R. (2003). Algal vs. macrophyte inputs to food webs of inland saline wetlands. Ecology, 84(12), 3317-3326.

Harvey, H. R., \& Macko, S. A. (1997). Kinetics of phytoplankton decay during simulated sedimentation: changes in lipids under oxic and anoxic conditions. Organic Geochemistry, 27(3-4), 129-140.

Harwood, J. L., \& Guschina, I. A. (2009). The versatility of algae and their lipid metabolism. Biochimie, 91(6), 679-684.

Iverson, S. J. (2009). Tracing aquatic food webs using fatty acids: from qualitative indicators to quantitative determination. In Lipids in aquatic ecosystems (pp. 281308). Springer, New York, NY.

Iverson, S.J., Field, C., Bowen, W.D., and Blanchard, W. 2004. Quantitative fatty acid signature analysis: a new method of estimating predator diets. Ecol. Monogr. 74:211-235.

Iwaniec, D. M., Childers, D. L., Rondeau, D., Madden, C. J., \& Saunders, C. (2006). Effects of hydrologic and water quality drivers on periphyton dynamics in the southern Everglades. Hydrobiologia, 569(1), 223-235.

Jordan, F., Coyne, S., and Trexler, J. C. (1997). Sampling fishes in vegetated habitats: effects of habitat structure on sampling characteristics of the $1-\mathrm{m}^{2}$ throw trap. Transactions of the American Fisheries Society, 126(6), 1012-1020.

Kainz, M., Arts, M.T., and Mazumder, A. 2004. Essential fatty acids within the planktonic food web and its ecological role for higher trophic levels. Limnol. Oceanogr. 49:1784-1793.

Kainz, M. J., \& Fisk, A. T. (2009). Integrating lipids and contaminants in aquatic ecology and ecotoxicology. In Lipids in aquatic ecosystems (pp. 93-114). Springer, New York, NY.

Kates K, Volcani BE (1966) Lipid components of diatoms. Biochimica et Biophysica Acta 116:264-278

Klein Breteler, W.C.M., Schogt, N., Baas, M., Schouten, S., and Kraay, G.W. 1999. Trophic upgrading of food quality by protozoans enhancing copepod growth: role of essential lipids. Mar. Biol. 135:191-198. 
Kotun, K., \& Renshaw, A. (2014). Taylor Slough hydrology. Wetlands, 34(1), 9-22.

Kushlan, J. A., and B. Hunt. 1979. Limnology of an alligator pond in South Florida. Florida Scientist 42:66-84.

Kwak, T. J., \& Zedler, J. B. (1997). Food web analysis of southern California coastal wetlands using multiple stable isotopes. Oecologia, 110(2), 262-277.

Loftus WF, Kushlan JA (1987) Freshwater fishes of southern Florida. Bull Florida State Mus Biol Sci 31:147-344

Longhi, D., Bartoli, M., \& Viaroli, P. (2008). Decomposition of four macrophytes in wetland sediments: Organic matter and nutrient decay and associated benthic processes. Aquatic Botany, 89(3), 303-310.

Lubzens, E., Marko, A., and Tietz, A. 1985. De novo synthesis of fatty acids in the rotifer, Brachionus plicatilis. Aquaculture 47: 27-37.

Lynn, S.G., Kilham, S.S., Kreeger, D.A., and Interlandi, S.J. 2000. Effect of nutrient availability on the biochemical and elemental stoichiometry in freshwater diatom Stephanodiscus minutulus (Bacillariophyceae). J. Phycol. 36:510-522.

McCormick, P. V., Shuford III, R. B., Backus, J. G., \& Kennedy, W. C. (1997). Spatial and seasonal patterns of periphyton biomass and productivity in the northern Everglades, Florida, USA. Hydrobiologia, 362(1-3), 185-210.

Meyer, A., Cirpus, P., Ott, C., Schlecker, R., Zähringer, U., and Heinz, E. 2003. Biosynthesis of docosahexaenoic acid in Euglena gracilis: biochemical and molecular evidence for the involvement of a D4-fatty acyl group desaturase. Biochemistry 42:9779-9788.

Mfilinge, P. L., Meziane, T., Bachok, Z., \& Tsuchiya, M. (2003). Fatty acids in decomposing mangrove leaves: microbial activity, decay and nutritional quality. Marine Ecology Progress Series, 265, 97-105.

Moore JC, Berlow EL, Coleman DC, deRuiter PC, Dong Q, Hastings A, Johnson NC, McCann KS, Melville K, Morin PJ, Nadelhoffer K, Rosemond AD, Post DM, Sabo JL, Scow KM, Vanni MJ, Wall DH (2004) Detritus, trophic dynamics and biodiversity. Ecology Letters 7:584-600.

Napolitano, G.E. 1999. Fatty acids as trophic and chemical markers in freshwater ecosystems, pp. 21-44. In M.T. Arts, and B.C wainman (eds.), Lipids in freshwater ecosystems. Springer, New York. 
Nelson, G.J. 1992. Dietary fatty acids and lipid metabolism, pp. 437-471. In C.K. Chow (ed.), Fatty Acids in Foods and Their Health Implications. Marcel Dekker, New York.

Neto, R. R., Mead, R. N., Louda, J. W., \& Jaffé, R. (2006). Organic biogeochemistry of detrital flocculent material (floc) in a subtropical, coastal wetland.

Biogeochemistry, 77(3), 283-304.

Noe, G. B., D. L. Childers, L. J. Scinto, A. L. Edwards, E. Gaiser, D. Lee, J. Trexler, and R. D. Jones. 2002. Short-term changes in phosphorus storage in an oligotrophic Everglades wetland ecosystem receiving experimental nutrient enrichment. Biogeochemistry 59:239-267.

Notter, S. J., Stuart, B. H., Rowe, R., \& Langlois, N. (2009). The initial changes of fat deposits during the decomposition of human and pig remains. Journal of Forensic Sciences, 54(1), 195-201.

Obaza, A., D. L. DeAngelis, and J. C. Trexler. 2011. Using data from an encounter sampler to model fish dispersal. Journal of Fish Biology 78:495-513.

Palmer, M. L., and F. J. Mazzotti. 2004. Structure of everglades alligator holes. Wetlands 24:115-122.

Parrish, C. C. (2009). Essential fatty acids in aquatic food webs. In Lipids in aquatic ecosystems (pp. 309-326). Springer, New York, NY.

Poerschmann, J., Spijkerman, E., and Langer, U. 2004. Fatty acid patterns in Chlamydomonas sp. as a marker for nutritional regimes and temperature under extremely acidic conditions. Microbiol. Ecol. 48:78-89.

Polis, G. A., \& Strong, D. R. (1996). Food web complexity and community dynamics. The American Naturalist, 147(5), 813-846.

Polis, G. A., W. B. Anderson, and R. D. Holt. 1997. Toward an integration of landscape and food web ecology: the dynamics of spatially subsidized food webs. Annual Review of Ecology and Systematics 28:289-316.

Pruitt, N. L. 1990. Adaptations to temperature in the cellular membranes of crustacea: Membrane structure and metabolism. J.Therm. Biol.15:1-8.

Rehage, J. S., \& Sih, A. (2004). Dispersal behavior, boldness, and the link to invasiveness: a comparison of four Gambusia species. Biological Invasions, 6(3), 379-391. 
Roman J and McCarthy JJ. 2010. The whale pump: marine mammals enhance primary productivity in a coastal basin. PLoS ONE 5: e13255.

Rosenblatt, A. E., and M. R. Heithaus. 2011. Does variation in movement tactics and trophic interactions among American alligators create habitat linkages? The Journal of Animal Ecology 80:786-798.

Ruetz III, C. R., Trexler, J. C., Jordan, F., Loftus, W. F., \& Perry, S. A. (2005). Population dynamics of wetland fishes: spatio-temporal patterns synchronized by hydrological disturbance?. Journal of Animal Ecology, 74(2), 322-332.

Sanchez, J. L., \& Trexler, J. C. (2018). When is an herbivore not an herbivore? Detritivory facilitates herbivory in a freshwater system. Ecology and evolution, 8(12), 5977-5991.

Sanders, D., C. G. Jones, E. Thébault, T. J. Bouma, T. van der Heide, J. van Belzen, and S. Barot. 2014. Integrating ecosystem engineering and food webs. Oikos 123:513-524.

Sargent, J. R., McEvoy, L. A., and Bell, J. G. 1997. Requirements, presentation and sources of polyunsaturated fatty acids in marine fish larval feeds. Aquaculture $155: 117-127$

Schlacher, T. A., \& Connolly, R. M. (2014). Effects of acid treatment on carbon and nitrogen stable isotope ratios in ecological samples: a review and synthesis. Methods in Ecology and Evolution, 5(6), 541-550.

Schmitz, O. J., D. Hawlena, and G. C. Trussell. 2010. Predator control of ecosystem nutrient dynamics. Ecology Letters 13:1199-1209.

Subalusky, A. L., L. A. Fitzgerald, and L. L. Smith. 2009. Ontogenetic niche shifts in the American alligator establish functional connectivity between aquatic systems. Biological Conservation 142:1507-1514.

Taylor AN, Batzer DP (2010) Spatial and temporal variation in invertebrate consumer diets in forested and herbaceous wetlands. Hydrobiologia 651:145-159

Taylor, R. C., Trexler, J. C., \& Loftus, W. F. (2001). Separating the effects of intra-and interspecific age-structured interactions in an experimental fish assemblage. Oecologia, 127(1), 143-152.

Tocher, D.R. 2003. Metabolism and functions of lipids and fatty acids in teleost fish. Rev. Fish. Sci. 11:107-184. 
Turner, A. M., Trexler, J. C., Jordan, C. F., Slack, S. J., Geddes, P., Chick, J. H., \& Loftus, W. F. (1999). Targeting ecosystem features for conservation: standing crops in the Florida Everglades. Conservation Biology, 13(4), 898-911.

Volkman JK, Johns RB, Gillan FT, Perry GJ, Bavor HJ (1980) Microbial lipids of an inter-tidal sediment. 1. Fatty-acids and hydrocarbons. Geochimica et Cosmochimica Acta 44:1133-1143

Wallis, J.G. and Browse, J. 1999. The D8 desaturase of Euglena gracilis: an alternate pathway for synthesis of 20-carbon polyunsaturated fatty acids. Archiv. Biochem. Biophys. 365:307-316.

Williams, A. J., and J. C. Trexler. 2006. A preliminary analysis of the correlation of foodweb characteristics with hydrology and nutrient gradients in the southern Everglades. Hydrobiologia 569:493-504.

Wright, J. P., and C. G. Jones. 2006. The concept of organisms as ecosystem engineers ten years on: progress, limitations, and challenges. BioScience 56:203.

Wright, J. P., C. G. Jones, and A. S. Flecker. 2002. An ecosystem enginer, the beaver, increases species richness at the landscape scale. Oecologia 132:96-101.

Yang, X., and Dick, T. A. 1994. Arctic char (Salvelinus alpinus) and rainbow trout (Oncorhynchus mykiss) differ in their growth and lipid metabolism in response to dietary polyunsaturated fatty acids. Can. J. Fish. Aquat. Sci. 51:1391-1400. J. Plankton Res. 14:495-512.

Zou, K., Thébault, E., Lacroix, G., \& Barot, S. (2016). Interactions between the green and brown food web determine ecosystem functioning. Functional Ecology, 30(8), 1454-1465. 
Table 1: Source assignment of fatty acid biomarkers used in this study (modified from Belicka et al. 2012). We present fatty acids as A:B $\omega C$, where A describes the number of carbon atoms, $\mathrm{B}$ is the number of double bonds, and $\mathrm{C}$, if needed, gives the location of the first double bond from the methyl end. We abbreviated iso- $(i)$, anteiso- $(a)$, and methyl $(M e)$.

\begin{tabular}{|c|c|c|}
\hline $\begin{array}{l}\text { Group Assignment } \\
\text { (used in this study) }\end{array}$ & Fatty Acid Source & References \\
\hline Bacteria & 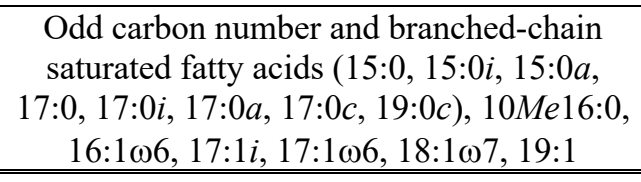 & $\begin{array}{l}\text { Findlay and Dobbs (1993), } \\
\text { Napolitano (1999) and } \\
\text { references therein, } \\
\text { Volkman et al. (1980) } \\
\end{array}$ \\
\hline Vascular Plants & $\mathrm{C}_{22}-\mathrm{C}_{32}$ saturated fatty acids & Eglinton and Hamilton (1967) \\
\hline \multirow{6}{*}{ Algae } & $\begin{array}{l}\text { 14:0, } 16: 1 \omega 7: \text { multiple sources, but high in } \\
\text { diatoms and some cyanobacteria }\end{array}$ & $\begin{array}{l}\text { Napolitano }(1999) \text { and } \\
\text { reference therein }\end{array}$ \\
\hline & $\begin{array}{l}\mathrm{C}_{16-22} \text { even carbon number poly-unsaturated } \\
\text { fatty acids: green algae and diatoms }\end{array}$ & $\begin{array}{l}\text { Kates and Volcani (1966), } \\
\text { Cranwell et al. (1990), } \\
\text { Napolitano (1999) }\end{array}$ \\
\hline & 18:3 $\omega 3$ : green algae, cyanobacteria & $\begin{array}{l}\text { Ahlgren et al. (1992), } \\
\text { Dalsgaard et al. (2003) }\end{array}$ \\
\hline & 18:3 $\omega 6:$ cyanobacteria & Napolitano (1999) \\
\hline & 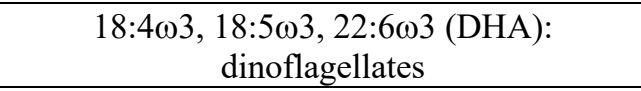 & $\begin{array}{l}\text { Ahlgren et al. (1992), } \\
\text { Dalsgaard et al. (2003) }\end{array}$ \\
\hline & 20:5 $\omega 3$ (EPA): diatoms & $\begin{array}{l}\text { Napolitano (1999), } \\
\text { Dalsgaard et al. (2003) }\end{array}$ \\
\hline
\end{tabular}


Table 2: Multivariate analysis of variance for arcsine-square-root transformed proportion of total of fatty acids of flocculent detrital material grouped by source (algal, bacterial, plant) collected at marsh, near-pond, and pond habitats at ten sites in Taylor Slough and Shark River Slough in the 2018 wet and 2019 dry seasons.

\begin{tabular}{|c|c|c|c|c|c|c|}
\hline Source & df & Pillai & Approximated F & num df & den df & $\boldsymbol{p}$ \\
\hline Habitat & 2 & 0.64 & 6.30 & 6 & 80 & $<\mathbf{0 . 0 1}$ \\
\hline Season & 1 & 0.11 & 1.55 & 3 & 39 & 0.22 \\
\hline Slough & 1 & 0.12 & 1.74 & 3 & 39 & 0.17 \\
\hline Habitat*Season & 2 & 0.20 & 1.50 & 6 & 80 & 0.19 \\
\hline Habitat*Slough & 2 & 0.24 & 1.80 & 6 & 80 & 0.11 \\
\hline Season*Slough & 1 & 0.09 & 1.23 & 3 & 39 & 0.31 \\
\hline Habitat*Season*Slough & 1 & 0.08 & 1.19 & 3 & 39 & 0.32 \\
\hline Residuals & 41 & & & & & \\
\hline
\end{tabular}


Table 3: Univariate analysis of variance for arcsine-square-root transformed proportion of total of fatty acids grouped by source (algal, bacterial, plant) in flocculent detrital

material among habitats at ten sites in Taylor Slough and Shark River Slough in the 2018 wet and 2019 dry seasons.

\begin{tabular}{|c|c|c|c|c|c|c|}
\hline Effect & Source Contribution & num df & den df & F & $\boldsymbol{p}$ & ges \\
\hline \multirow{3}{*}{ Habitata } & Algal & 2 & 49 & 3.94 & $\mathbf{0 . 0 3}$ & 0.14 \\
\cline { 2 - 7 } & Bacterial & 2 & 49 & 3.11 & 0.05 & 0.11 \\
\cline { 2 - 7 } & Plant & 2 & 49 & 12.00 & $<\mathbf{0 . 0 1}$ & 0.33 \\
\hline
\end{tabular}


Table 4: Post-hoc Tukey's honest significance differences for arcsine-square-root transformed proportion of total of fatty acids grouped by source (algal, bacterial, plant) in flocculent detrital material among habitats at ten sites in Taylor Slough and Shark River Slough in the 2018 wet and 2019 dry seasons.

\begin{tabular}{|c|c|c|c|}
\hline Effect & $\begin{array}{c}\text { Source } \\
\text { Contribution }\end{array}$ & Comparison & Adjusted $p$ \\
\hline \multirow{9}{*}{ Habitat } & \multirow{3}{*}{ Algal } & Marsh - Near-pond & 0.19 \\
\hline & & Marsh - Pond & 0.02 \\
\hline & & Near-pond - Pond & 0.68 \\
\hline & \multirow{3}{*}{ Bacterial } & Marsh - Near-pond & 0.06 \\
\hline & & Marsh - Pond & 0.91 \\
\hline & & Near-pond - Pond & 0.14 \\
\hline & \multirow{3}{*}{ Plant } & Marsh-Near-pond & $<0.01$ \\
\hline & & Marsh - Pond & $<0.01$ \\
\hline & & Near-pond - Pond & 0.50 \\
\hline
\end{tabular}


Table 5: Analysis of variance for sum total of essential fatty acids, LIN, and the ratio of saturated and unsaturated to poly-unsaturated fatty acids all as a percent total of fatty acids of flocculent detrital material grouped by source (algal, bacterial, plant) collected at marsh, near-pond, and pond habitats at ten sites in Taylor Slough and Shark River Slough in the 2018 wet and 2019 dry seasons. The dry season error structure was singular because of unequal sampling; addition of random error did not affect significance conclusions. The ratio of (SAFA + MUFA):PUFA was $\log -10(x+1)$ transformed.

\begin{tabular}{|c|c|c|c|c|c|c|c|c|}
\hline $\begin{array}{c}\text { Dependent } \\
\text { Variable }\end{array}$ & Season & Error & Source & df & $\begin{array}{c}\text { Sum of } \\
\text { Squares }\end{array}$ & $\begin{array}{l}\text { Mean } \\
\text { Square }\end{array}$ & $\mathbf{F}$ & $p$ \\
\hline \multirow{7}{*}{$\begin{array}{l}\text { Sum of } \\
\text { essential fatty } \\
\text { acids }\end{array}$} & \multirow{5}{*}{ Wet } & \multirow{2}{*}{ Site } & Slough & 1 & 0.41 & 0.41 & 1.24 & 0.30 \\
\hline & & & Residuals & 8 & 2.65 & 0.33 & & \\
\hline & & \multirow{3}{*}{ Site*Habitat } & Habitat & 2 & 0.04 & 0.02 & 0.06 & 0.94 \\
\hline & & & Habitat*Slough & 2 & 1.55 & 0.77 & 2.18 & 0.15 \\
\hline & & & Residuals & 16 & 5.67 & 0.35 & & \\
\hline & \multirow{2}{*}{ Dry } & \multirow{2}{*}{ Singular } & Habitat & 2 & 1.18 & 0.59 & 0.96 & 0.40 \\
\hline & & & Residuals & 19 & 11.59 & 0.61 & & \\
\hline \multirow{7}{*}{ LIN } & \multirow{5}{*}{ Wet } & \multirow{2}{*}{ Site } & Slough & 1 & 0.41 & 0.41 & 1.24 & 0.30 \\
\hline & & & Residuals & 8 & 2.65 & 0.33 & & \\
\hline & & \multirow{3}{*}{ Site*Habitat } & Habitat & 2 & 0.04 & 0.02 & 0.06 & 0.94 \\
\hline & & & Habitat*Slough & 2 & 1.55 & 0.77 & 2.18 & 0.15 \\
\hline & & & Residuals & 16 & 5.67 & 0.35 & & \\
\hline & \multirow{2}{*}{ Dry } & \multirow{2}{*}{ Singular } & Habitat & 2 & 1.07 & 0.54 & 1.01 & 0.38 \\
\hline & & & Residuals & 19 & 10.07 & 0.53 & & \\
\hline \multirow{7}{*}{$\begin{array}{c}\text { (SAFA }+ \\
\text { MUFA): PUFA }\end{array}$} & \multirow{5}{*}{ Wet } & \multirow{2}{*}{ Site } & Slough & 1 & 0.07 & 0.07 & 3.96 & 0.08 \\
\hline & & & Residuals & 8 & 0.15 & 0.02 & & \\
\hline & & \multirow{3}{*}{ Site*Habitat } & Habitat & 2 & 0.05 & 0.03 & 1.53 & 0.25 \\
\hline & & & Habitat*Slough & 2 & 0.08 & 0.04 & 2.29 & 0.13 \\
\hline & & & Residuals & 16 & 0.27 & 0.02 & & \\
\hline & \multirow[t]{2}{*}{ Dry } & \multirow[t]{2}{*}{ Singular } & Habitat & 2 & 0.11 & 0.05 & 6.43 & $\begin{array}{c}< \\
0.01\end{array}$ \\
\hline & & & Residuals & 19 & 0.16 & 0.01 & & \\
\hline
\end{tabular}


Table 6: Multivariate analysis of variance for arcsine-square-root transformed proportion of total of fatty acids of periphyton mats grouped by source (algal, bacterial, plant) collected at marsh habitats at ten sites in Taylor Slough and Shark River Slough in the 2018 wet and 2019 dry seasons.

\begin{tabular}{|c|c|c|c|c|c|c|}
\hline Source & df & Pillai & Approximated F & num df & den df & $\boldsymbol{p}$ \\
\hline Season & 1 & 0.20 & 0.83 & 3 & 10 & 0.51 \\
\hline Slough & 1 & 0.54 & 3.96 & 3 & 10 & $\mathbf{0 . 0 4}$ \\
\hline Season*Slough & 1 & 0.48 & 3.02 & 3 & 10 & 0.08 \\
\hline Residuals & 12 & & & & & \\
\hline
\end{tabular}


Table 7: Univariate analysis of variance for arcsine-square-root transformed proportion of total of fatty acids grouped by source (algal, bacterial, plant) in periphyton mats in marsh habitats at ten sites in Taylor Slough and Shark River Slough in the 2018 wet and 2019 dry seasons.

\begin{tabular}{|c|c|c|c|c|c|c|}
\hline Effect & Source Contribution & num df & den df & F & $\boldsymbol{p}$ & ges \\
\hline \multirow{3}{*}{ Slough } & Algal & 1 & 14 & 10.20 & $<\mathbf{0 . 0 1}$ & 0.42 \\
\cline { 2 - 7 } & Bacterial & 1 & 14 & 0.12 & 0.73 & 0.01 \\
\cline { 2 - 7 } & Plant & 1 & 14 & 2.41 & 0.14 & 0.15 \\
\hline
\end{tabular}


Table 8: Analysis of variance for sum total of essential fatty acids, LIN, ARA, and the ratio of saturated and unsaturated to poly-unsaturated fatty acids all as a percent total of fatty acids of periphyton mats grouped by source (algal, bacterial, plant) collected at marsh habitats at ten sites in Taylor Slough and Shark River Slough in the 2018 wet and 2019 dry seasons. The ratio of (SAFA + MUFA):PUFA was log-10 $(x+1)$ transformed.

\begin{tabular}{|c|c|c|c|c|c|c|c|}
\hline $\begin{array}{l}\text { Dependent } \\
\text { Variable }\end{array}$ & Error & Source & df & $\begin{array}{c}\text { Sum of } \\
\text { Squares }\end{array}$ & $\begin{array}{c}\text { Mean } \\
\text { Square }\end{array}$ & $\mathbf{F}$ & $p$ \\
\hline \multirow{5}{*}{$\begin{array}{l}\text { Sum of } \\
\text { essential fatty } \\
\text { acids }\end{array}$} & \multirow{2}{*}{ Site } & Slough & 1 & 0.66 & 0.66 & 0.17 & 0.70 \\
\hline & & Residuals & 5 & 19.63 & 3.93 & & \\
\hline & \multirow{3}{*}{ Site*Season } & Season & 1 & 0.11 & 0.11 & 0.01 & 0.91 \\
\hline & & Season*Sough & 1 & 3.15 & 3.15 & 0.40 & 0.55 \\
\hline & & Residuals & 5 & 39.28 & 7.86 & & \\
\hline \multirow{5}{*}{ LIN } & \multirow{2}{*}{ Site } & Slough & 1 & 3.74 & 3.74 & 2.65 & 0.17 \\
\hline & & Residuals & 5 & 7.05 & 1.41 & & \\
\hline & \multirow{3}{*}{ Site*Season } & Season & 1 & 0.11 & 0.10 & 0.08 & 0.80 \\
\hline & & Season*Sough & 1 & 2.34 & 2.35 & 1.69 & 0.25 \\
\hline & & Residuals & 5 & 6.97 & 1.39 & & \\
\hline \multirow{5}{*}{ ARA } & \multirow{2}{*}{ Site } & Slough & 1 & 0.27 & 0.27 & "5.68 & 0.06 \\
\hline & & Residuals & 5 & 0.24 & 0.05 & & \\
\hline & \multirow{3}{*}{ Site*Season } & Season & 1 & 0.05 & 0.05 & 1.38 & 0.29 \\
\hline & & Season*Sough & 1 & 0.00 & 0.00 & 0.06 & 0.82 \\
\hline & & Residuals & 5 & 0.19 & 0.04 & & \\
\hline \multirow{5}{*}{$\begin{array}{c}\text { (SAFA + } \\
\text { MUFA): } \\
\text { PUFA }\end{array}$} & \multirow{2}{*}{ Site } & Slough & 1 & 0.02 & 0.02 & 1.47 & 0.28 \\
\hline & & Residuals & 5 & 0.07 & 0.01 & & \\
\hline & \multirow{3}{*}{ Site*Season } & Season & 1 & 0.01 & 0.01 & 0.55 & 0.49 \\
\hline & & Season*Sough & 1 & 0.00 & 0.00 & 0.27 & 0.63 \\
\hline & & Residuals & 5 & 0.05 & 0.01 & & \\
\hline
\end{tabular}


Figure 1: Alligator pond sites in Taylor Slough and Shark River Slough, Everglades, Florida, USA in the 2018 wet and 2019 dry seasons.

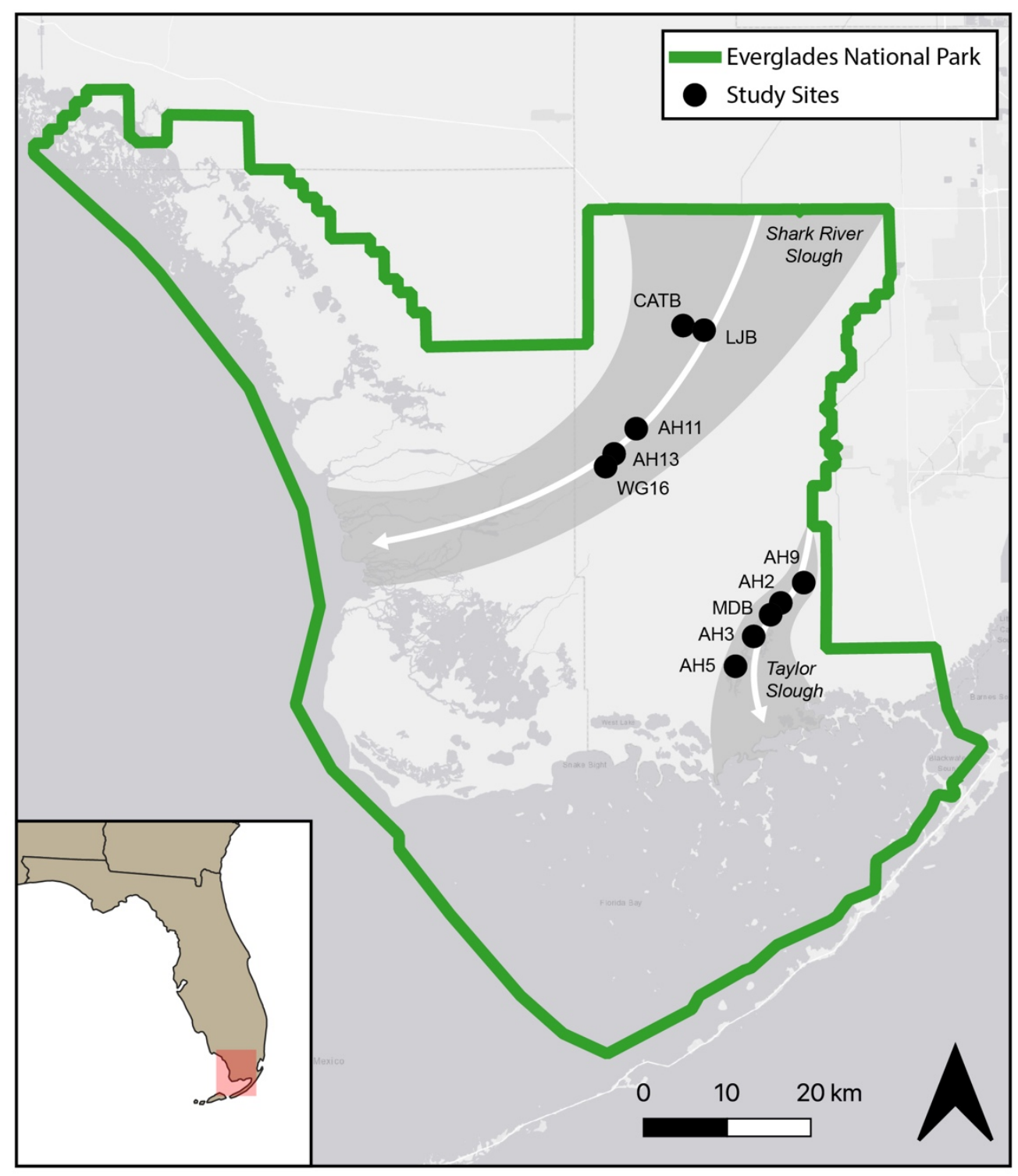


Figure 2: Mean percent total of fatty acids for flocculent detrital material grouped by source (algal, bacterial, plant) collected at marsh, near-pond, and pond habitats at ten sites in Taylor Slough and Shark River Slough in the 2018 wet and 2019 dry seasons. Error bars denote 1 standard deviation from the mean. For each source, analysis of variance (ANOVA) and post-hoc Tukey's Honest Significant Differences (HSD) compared differences in means across habitats evaluated at $\alpha=0.05$.
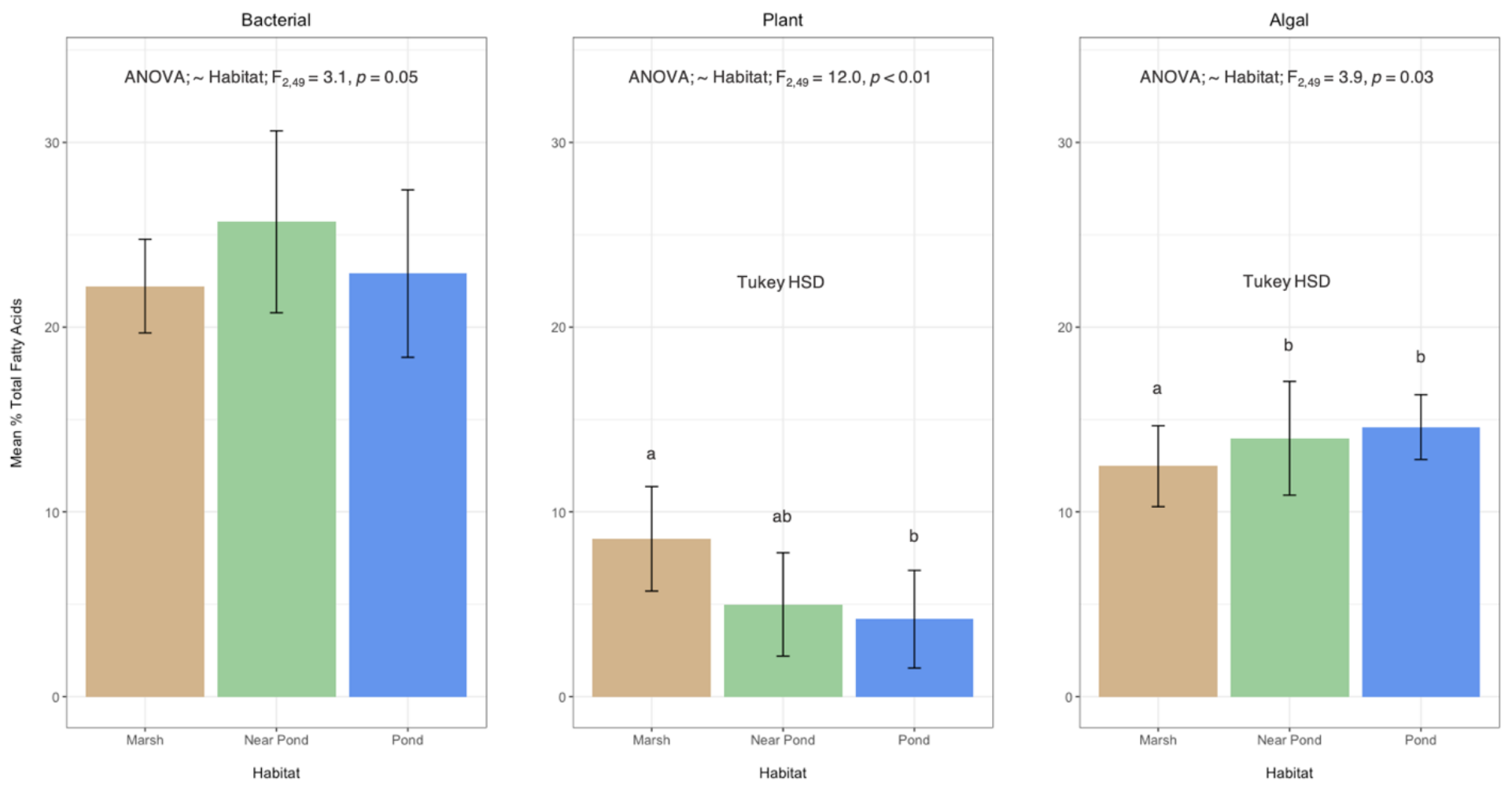
Figure 3: Mean percent total of fatty acids for periphyton mats grouped by source (algal, bacterial, plant) collected in marsh habitats at ten sites in Taylor Slough and Shark River Slough in the 2018 wet and 2019 dry seasons. Error bars denote 1 standard deviation from the mean.
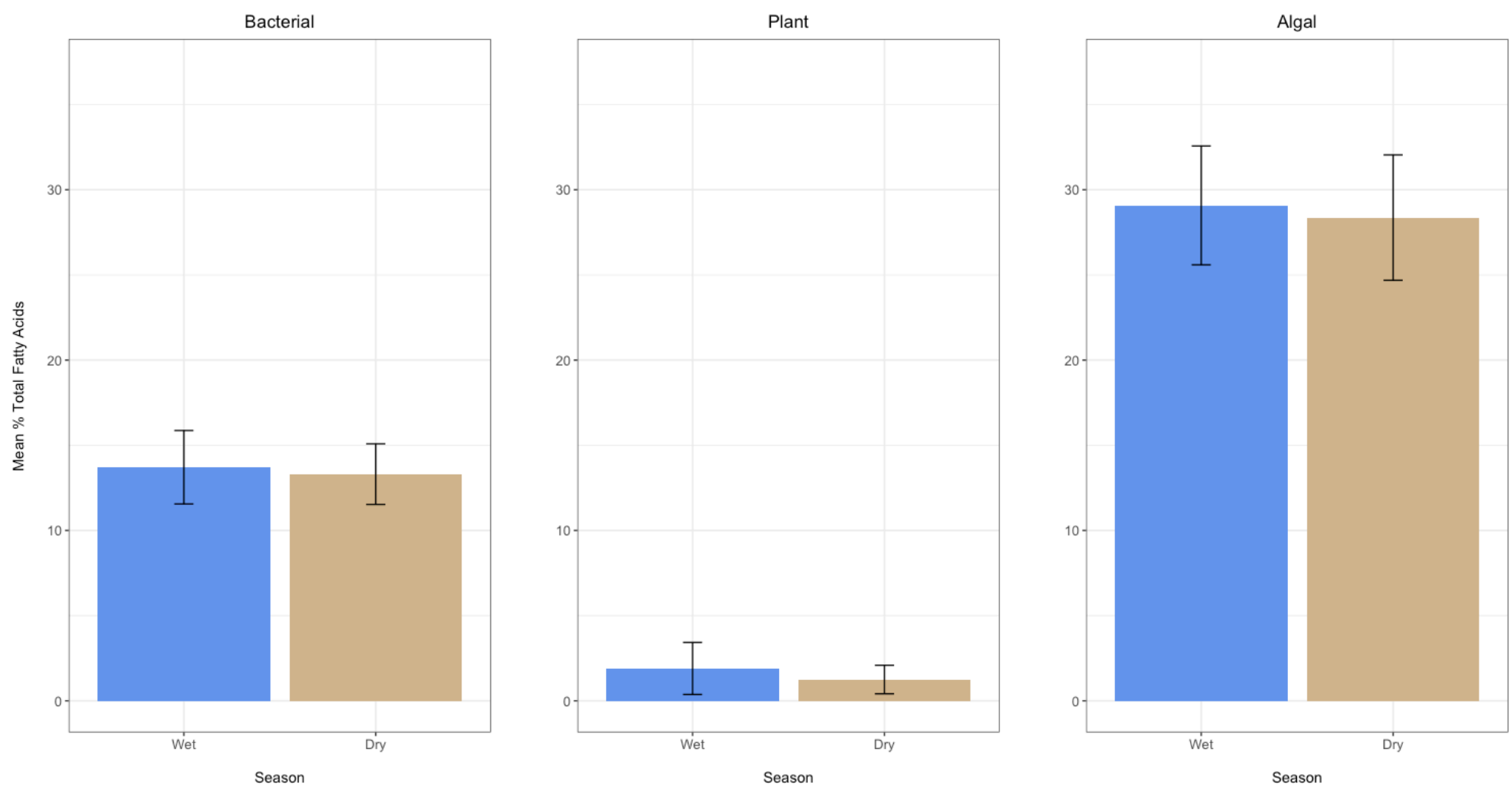
Figure 4: Mean percent total of fatty acids for consumers grouped by source (algal, bacterial, plant) collected at marsh and pond habitats at ten sites in Taylor Slough and Shark River Slough in the 2018 wet and 2019 dry seasons. Error bars denote 1 standard deviation from the mean. Species were abbreviated by the first three letters of genus and species: GAMHOL $=$ Gambusia holbrooki (Eastern Mosquitofish), LUCGOO = Lucania goodei (Bluefin Killifish), and PALPAL = Palaemonetes paludosus $($ grass shrimp).
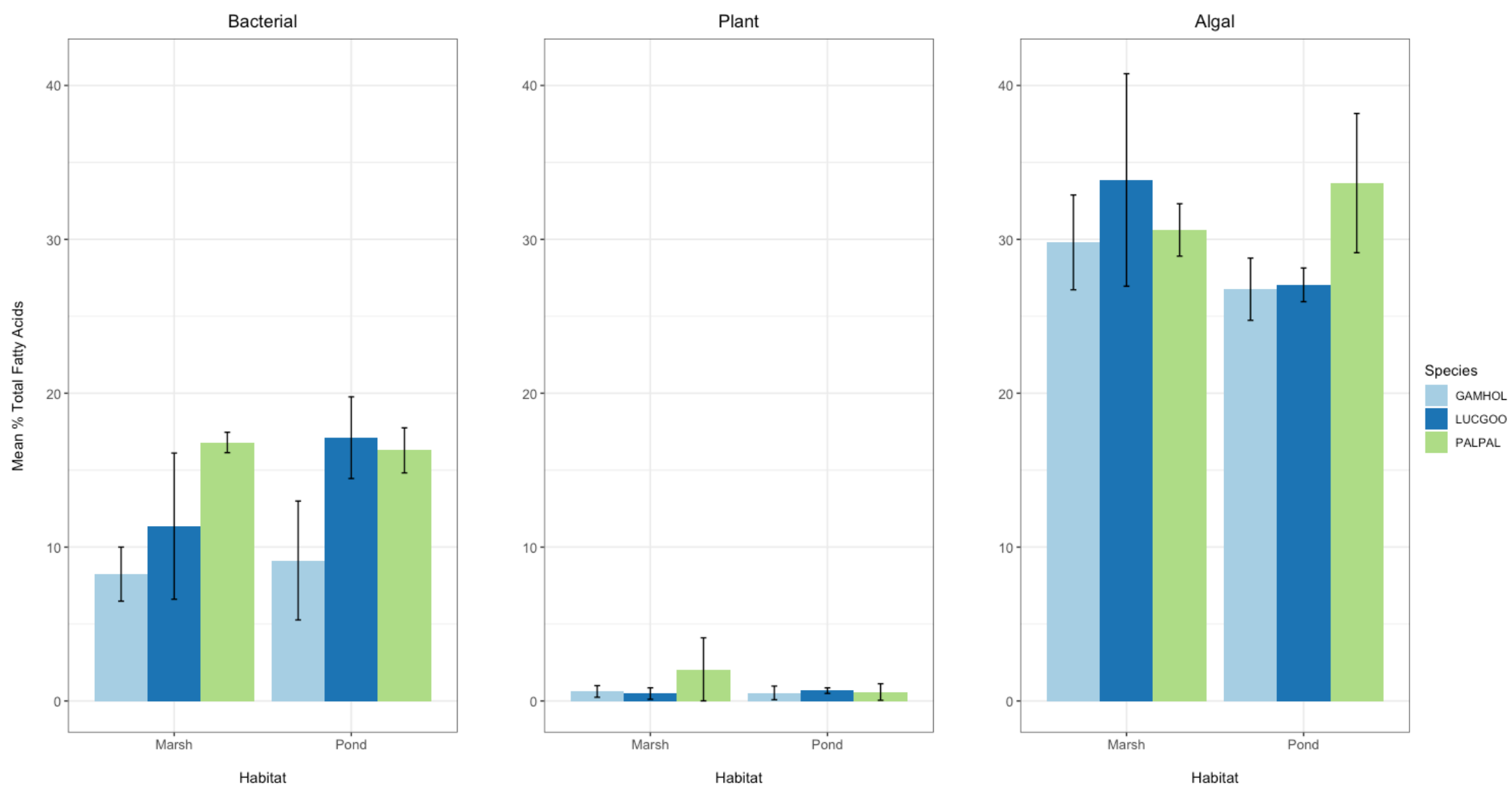
Table A1: Aquatic plants sampled in marsh, near pond, and pond habitats at ten sites in Taylor Slough and Shark River Slough, Everglades, Florida, USA in the 2018 wet and 2019 dry seasons.

\begin{tabular}{|c|c|}
\hline Common Name & Scientific Name \\
\hline Sawgrass & Cladium jamaicense \\
\hline Gulfcoast spikerush & Eleocharis cellulosa \\
\hline Slim spikerush & Eleocharis elongata \\
\hline Green arrow arum & Peltandra virginica \\
\hline Eastern purple bladderwort & Utricularia purpurea \\
\hline Leafy bladderwort & Utricularia foliosa \\
\hline Duck potato & Sagitarria lancifolia \\
\hline Pickerelweed & Pontedaria cordata \\
\hline Spider lily & Hymenocallis latifolia \\
\hline Tracy's beaksedge & Rhycospora tracyi \\
\hline Maidencane & Panicum hemitonum \\
\hline Lemon bacopa & Bacopa carolinia \\
\hline Pondweed & Potamogeton illinoensis \\
\hline Red ludwigia & Ludwigia repens \\
\hline Banana lily & Nymphoides aquatica \\
\hline Southern cattail & Tyhpa domingensis \\
\hline Spatterdock & Nuphar advena \\
\hline Egyptian paspaladium & Paspaladium geminatum \\
\hline
\end{tabular}




\section{CHAPTER VI}

GENERAL CONCLUSION 
Worldwide rapid declines of large-bodied apex predators have been documented across multiple ecosystem types (Heithaus et al. 2008, Estes et al. 2011). Thus, understanding their role in both top-down and bottom-up forcing is more valuable than ever to accurately predict effects on community and ecosystem structure and function. Even though alligator populations have recovered or are recovering throughout the southeastern United States, they have a rich conservation history and are an intensively managed species. For instance, in the Everglades, alligators historically were abundant in the peripheral marshes however, now they are more localized in the central slough habitats (Mazzotti and Brandt 1994). Currently, the drained Everglades is considered a harsh environment for alligators due to seasonal prey fluctuations from altered hydrology and anthropogenic disturbance (Dalrymple 1996). Here, alligator populations are relatively slow growing, reach sexual maturity later, and are in poor body condition compared to other parts of their range (Mazzotti et al. 2009). The distribution, timing, and volume of water flow is a key driver of ecological processes (e.g., distribution and abundance of organisms) in the Everglades and restoring a greater range in annual water depths has improved alligator body condition in some areas (Brandt et al. 2016). This is possibly due to an interaction of the low density and biomass of prey caused by drought and the population's reliance on a poor-quality diet (e.g., high proportions of invertebrate prey items opposed to mammals and large fish for adults in other parts of its range) (Mazzotti and Brandt 1994). The establishment of invasive species, such as the Burmese python (Python bivittatus), is also a likely stressor given their impacts on native fauna including declines in mammal populations (e.g., Dorcas et al. 2012). Nonetheless, alligators remain an abundant and important predator in the Everglades and wetlands 
across the southeastern United States. This dissertation research allowed for a deeper appreciation of alligators not only as predators, but as engineers of their own environment. In Chapters 2 and 3, I documented the potential scale of ecological impacts by studying alligator movement and habitat use across a range of environmental conditions and general habitats. Then, in Chapters 4 and 5 I elucidated the effects of alligators as ecosystem engineers on both community structure and ecosystem function (see Figure 1).

In Chapter 2, by studying the movements of alligators living in a transitional estuarine habitat, I observed considerable variation in individual movement tactics. Some animals exhibited commuting behavior by making regular trips from the mid-estuary to the coastal rivers or to the freshwater marshes. Overall, I found that movements of animals tagged in the freshwater marsh transition zone were more sedentary than those tagged in the coastal river. Several environmental drivers explained differences in movement patterns including temperature, water level, and salinity but the overall effect was dependent upon an animal's general location in the estuary. The variation observed in movement behavior may manifest into differences in ecological roles of individuals within the population, particularly given that the estuary exhibits a considerable gradient of productivity. For instance, individuals that commute to the prey-rich marine habitats from the mid-estuary may act as nutrient vectors. Also, individuals moving from the midestuary to the oligotrophic freshwater marsh may act to subsidize seasonal production in the marsh.

Chapter 3 revealed that a large-scale experimental water release in the early dry season increased the movement activity of alligators in a managed freshwater marsh. 
Though individual animals did not change space use across seasons, movement activity was lower and $\delta^{15}$ Nitrogen isotopic values were higher in the dry season possibly reflecting easier foraging opportunities when marsh dry down concentrates prey. Alligators strongly selected canal habitats at the home range scale, but selected sawgrass habitats at the patch scale within home ranges. Animals may be using canals as foraging sites that have abundant prey year-round and shallow sawgrass habitats as spots for basking. Beyond sex-specific differences, I also found that poorer body condition animals had higher movement activity rates and larger home ranges, particularly in the wet season likely to access resources spread across the marsh. These findings as a whole indicate that alligator movement and habitat use may be strongly tied to hydrology. Thus, the effects of ongoing restoration of water inflow and decompartmentalization will likely change the distribution, movement behavior, and potentially the ecological roles of alligators.

In Chapter 4, I demonstrated that alligator-engineered ponds are enriched and have different trophic structure relative to the surrounding marsh. For instance, I observed the near absence of mat-forming periphyton in ponds. I also saw that plant species associated with P-enrichment in wetlands, such as Typha domingensis, were only found in the pond and edge habitat. In addition, the edge habitat surrounding the pond contained the most diverse community of invertebrates likely driven by the abundance of dense emergent macrophytes not found in the pond or marsh habitats. However, not all ponds exhibited the same level of enrichment or trophic structure indicating that differences in local microtopography, alligator occupancy rates, and hydrological variables may influence the ecology of alligator ponds. Overall, we found that the 
impacts of alligator engineering are significant forces locally on nutrient cycling and trophic structure in an oligotrophic wetland.

Chapter 5 showed that alligators engineer habitats with dissimilarities in ecosystem function through shifted energy channels toward algal production compared to detrital pathways. I found alligator-engineered ponds had higher algal contributions compared to the marsh in the flocculent-detrital layer. Both algal and bacterial sources are important routes of energy and macronutrients for each consumer studied, but it was unclear whether these markers were obtained through prey or direct feeding in floc or periphyton. Also, vascular plants had high essential fatty acid precursors, but they may only be integrated into the food web by decomposition in floc as detritus. There were no differences of fatty acid profiles of consumers collected across the habitats, which may indicate potential trophic connectivity through animal movement or some other mechanism.

Almost a century of alligator research from McIlhenny (1935) to this dissertation has revealed much about the ecological roles of alligators. However, there are still many unknowns. Surprisingly, even the top-down effects of crocodilians as whole have been understudied with sparse evidence that they incite population reductions in prey (reviewed in Somaweera et al. 2020). The contribution of alligators exhibiting crossecosystem movements to nutrient fluxes has only been hypothesized (reviewed in Somaweera et al. 2020) with no studies using nutrient budget models or controlled field experiments to demonstrate the significance of these roles. In the freshwater marsh, the abundance and spatial extent of alligator ponds on a landscape scale is undetermined (but see Campbell and Mazzotti 2001; Brandt et al. 2010). In addition, to model the 
contributions of alligator ponds to nutrient cycling at the landscape level, future work will need to determine the biomass, excretion and egestion rates, and movement rates of alligators and other consumers inside and outside of ponds. The ecological effects of other engineering activities including nests, trails, slides, and dens (in northern latitudes) are relatively unexplored for all crocodilians (Somaweera et al. 2020). Perhaps most importantly, little is known about how external pressures like climate change and restoration efforts will affect the role that alligators play in creating nutrient and habitat heterogeneity.

Alligators are a charismatic predator of wetlands throughout the southeastern U.S. However, growing evidence is showing that their impact on ecosystems may go beyond the role of predator. The role of alligators as ecosystem engineers may be a particularly important one especially in areas where increased habitat heterogeneity and nutrient enrichment may yield positive effects on primary producers and lower trophic levels. Many abundant, generalist, top predators have high numbers of interactions with diverse competitors and prey species which may theoretically stabilize ecosystems (Rooney et al. 2006). Alligators serve as prey (e.g., Mazzotti and Brandt 1994), predators (e.g., Rosenblatt et al. 2015), and perhaps mutualists (e.g., Nell et al. 2016) in wetlands. The net effect of alligators as ecosystem engineers on emergent ecosystem and food-web properties is largely unknown. For instance, engineered ponds help diminish the severity of drydown effects and provide refuge for aquatic invertebrates and fishes (Kushlan 1974; Parkos et al. 2011). However, these refuges are not without their own source of danger including oxygen depletion, increased disease susceptibility, limited escape, and higher predator risk which may negatively affect users (DeAngelis et al. 1997; Dorn et al. 
2006). In addition, I provided some evidence that alligators shifted food webs towards more algal dominance. Detrital sources are generally considered slower energy channels and stabilizing forces in ecosystem function whereas algal channels lead to more efficient (faster) energy flow (Rooney and McCann 2012).

Overall, we still know little about the interacting roles of predator and engineer in ecology. Being able to tease apart the effects of types of trophic (and non-trophic) interactions is necessary to understand how ecosystems function (see Prugh and Brashares 2012). The biotic and abiotic factors that control the strength of engineering effects may not be the same factors that influence the effects of an animal's predator-prey interactions. Future modeling exercises and carefully controlled experiments may allow us to partition each role's impact on food webs and predict the effects of loss of function in one or both of these roles. These new models will be useful not only in understanding the structure of food webs, but also linking trophic interactions and ecosystem processes.

\section{Literature Cited}

Brandt, L. A., M. R. Campbell, and F. J. Mazzotti. 2010. Spatial distribution of alligator holes in the central Everglades. Southeastern Naturalist 9:487-496.

Brandt, L.A., J.S. Beauchamp, B.M. Jeffery, M.S. Cherkiss, and F.J. Mazzotti. 2016. Fluctuating water depths affect American alligator (Alligator mississippiensis) body condition in the Everglades, Florida, USA. Ecological Indicators 67:441450.

Campbell, M. R., \& Mazzotti, F. J. (2001). Mapping Everglades alligator holes using color infrared aerial photographs. Florida Scientist, 148-158.

Dalrymple, G. H. 1996. Growth of American alligators in the Shark Valley region of Everglades National Park. Copeia 1996:212-216. 
DeAngelis, D.L., W.F. Loftus, J.C. Trexler, and R.E. Ulanowicz. 1997. Modeling fish dynamics and effects of stress in a hydrologically pulsed ecosystem. Journal of Aquatic Ecosystem Stress and Recovery 6:1-13.

Dorcas, M. E., J. D. Willson, R. N. Reed, R. W. Snow, M. R. Rochford, M. A. Miller, W. E. Mehsaka, Jr., P. T. Andreadis, F. J. Mazzotti, C. M. Romagosa, and K. M. Hart. 2012. Severe mammal declines coincide with proliferation of invasive Burmese pythons in Everglades National Park. Proceedings of the National Academy of Sciences 109:2418-2422.

Dorn, N.J., J.C. Trexler, and E.E. Gaiser. 2006. Exploring the role of large predators in marsh food webs: evidence for a behaviorally-mediated trophic cascade. Hydrobiologia 569:375-386.

Estes, J. A., J. Terborgh, J. S. Brashares, M. E. Power, J. Berger, W. J. Bond, S. R. Carpenter, T. E. Essington, R. D. Holt, J. B. C. Jackson, R. J. Marquis, L. Oksanen, T. Oksanen, R. T. Paine, E. K. Pikitch, W. J. Ripple, S. A. Sandin, M. Scheffer, T. W. Schoener, J. B. Shurin, A. R. E. Sinclair, M. E. Soulé, R. Virtanen, and D. A. Wardle. 2011. Trophic downgrading of planet Earth. Science 333:301-306.

Heithaus, M. R., A. Frid, A. J. Wirsing, and B. Worm. 2008. Predicting ecological consequences of marine top predator declines. Trends in Ecology and Evolution 23:202-210.

Kushlan, J. A. 1974. Observations on the role of the American alligator in the Southern Flordia wetlands. Copeia 4:993-996.

Mazzotti, F. J., and L. A. Brandt. 1994. Ecology of the American alligator in a seasonally flucutating environment. S. M. Davis and W. A. Park, editors. Everglades: The Ecosystem and Its Restoration. St. Lucie Press.

Mazzotti, F. J., G. R. Best, L. A. Brandt, M. S. Cherkiss, B. M. Jeffery, and K. G. Rice. 2009. Alligators and crocodiles as indicators for restoration of Everglades ecosystems. Ecological Indicators 9:S137-S149.

McIlhenny, E. A. (1987). The alligator's life history. Ten Speed Pr.

Nell, L. A., Frederick, P. C., Mazzotti, F. J., Vliet, K. A., \& Brandt, L. A. (2016). Presence of breeding birds improves body condition for a crocodilian nest protector. PloS one, 11(3).

Parkos, J.J., C.R. Ruetz, and J.C. Trexler. 2011. Disturbance regime and limits on benefits of refuge use for fishes in a fluctuating hydroscape. Oikos 120:15191530 . 
Prugh, L. R., \& Brashares, J. S. (2012). Partitioning the effects of an ecosystem engineer: kangaroo rats control community structure via multiple pathways. Journal of Animal Ecology, 667-678.

Rooney, N., K. McCann, G. Gellner, and J. C. Moore. 2006. Structural asymmetry and the stability of diverse food webs. Nature 442:265-269.

Rooney, N., and K. S. McCann. 2012. Integrating food web diversity, structure and stability. Trends in Ecology \& Evolution 27:40-46.

Rosenblatt, A.E., J.C. Nifong, M.R. Heithaus, F.J. Mazzotti, M.S. Cherkiss, B.M. Jeffery, R.M. Elsey, R.A. Decker, B.R. Silliman, L.J. Guillette, R.H. Lowers, J.C. Larson. 2015. Factors affecting individual foraging specialization and diet stability across the range of a large "generalist" apex predator. Oecologia 178:5-16.

Somaweera, R., Nifong, J., Rosenblatt, A., Brien, M. L., Combrink, X., Elsey, R. M., ... $\&$ Webber, B.L. (2020). The ecological importance of crocodylians: towards evidence-based justification for their conservation. Biological Reviews, doi: 10.1111/brv.12594. 
Figure 1: Conceptual model of the effects of predation and engineering on community structure and ecosystem function.

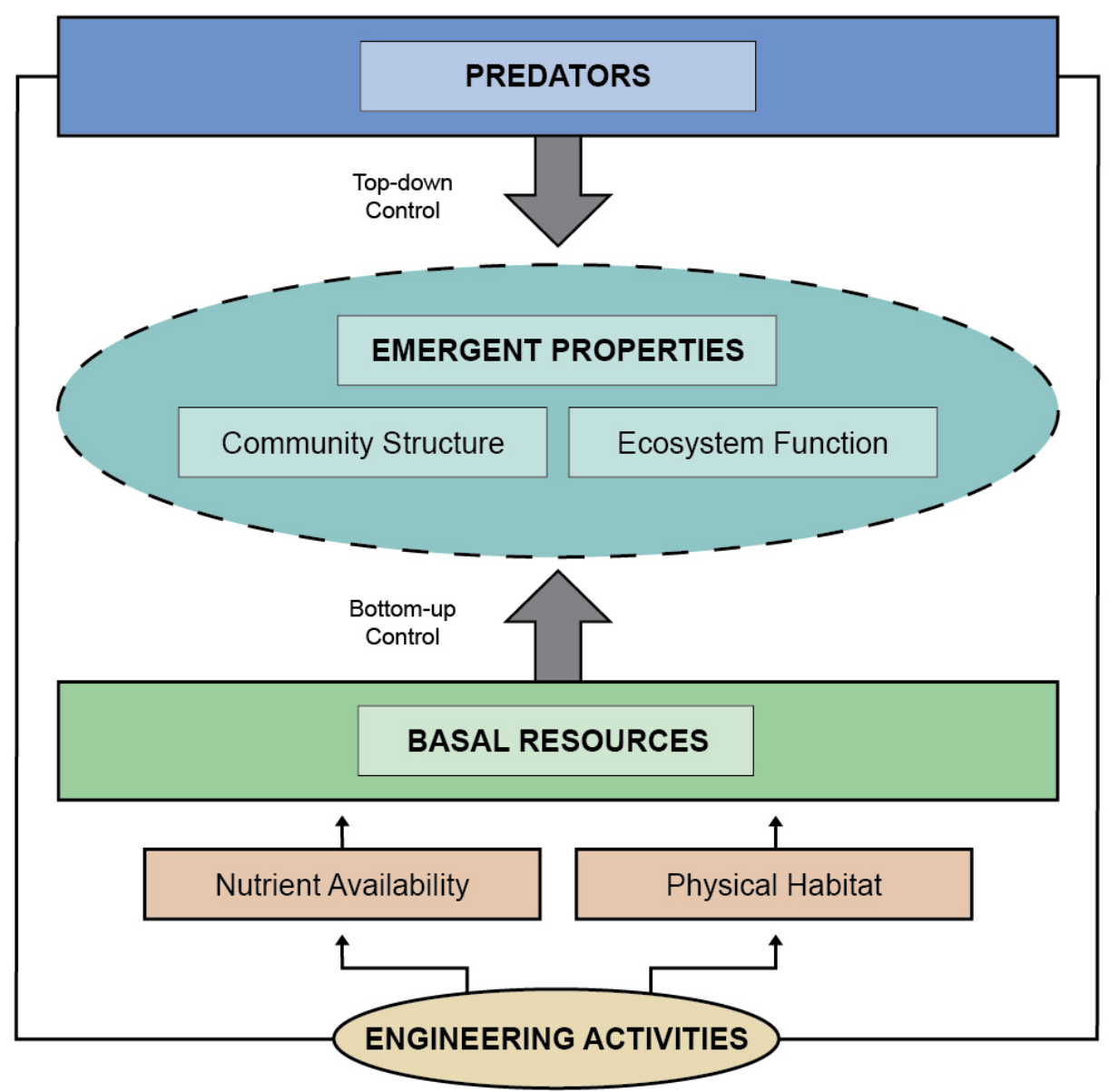


VITA

BRADLEY AUSTIN STRICKLAND

2008-2011

B.S., Environmental Sciences

Berry College

Mt. Berry, Georgia

2011-2015

M.S., Wildlife Sciences

Mississippi State University

Starkville, Mississippi

\section{PUBLICATIONS}

Hogan, JA, et al. (BA Strickland). 2020. A research framework to integrate crossecosystem responses to tropical cyclones. Bioscience 70(6): 477-489.

Lawson, AJ, BA Strickland, and AE Rosenblatt. 2018. Patterns, drivers, and effects of alligator movements. In American Alligators: Habitats, Behaviors, and Threats. Eds: C.B. Eversole and S.E. Henke. Nova Science Publishers, Hauppauge, New York, USA.

Massie, JA, BA Strickland, RO Santos, J Hernandez, N Viadero, RE Boucek, H Willoughby, MR Heithaus, and JS Rehage. 2019. Going downriver: patterns and cues in hurricane-driven movements of common snook in a subtropical coastal river. Estuaries and Coasts doi: 10.1007/s12237-019-00617-y.

Matich, P, BA Strickland, and MR Heithaus. 2020. Long-term monitoring provides insight into estuarine top predator (Carcharhinus leucas) resilience following an extreme weather event. Marine Ecology Progress Series 639:169-183.

Matich, P, RJ Nowicki, J Davis, JA Mohan, JD Plumlee, BA Strickland, TC TinHan, RJD Wells, and M Fisher. 2020. Does proximity to freshwater refuge influence the body size structure of an estuarine predator (Carcharhinus leucas) in the northwestern Gulf of Mexico? Marine and Freshwater Research doi: 10.1071/MF19346.

Strickland, BA, K Gastrich, FJ Mazzotti, JA Massie, V Paz, N Viadero, JS Rehage, and MR Heithaus. 2020. Variation in movement behaviors of alligators after a major hurricane. Animal Biotelemetry 8(7): 1-10. 
Strickland, BA, JA Massie, N Viadero, R Santos, V Paz, KR Gastrich, P O’Donnell, A Kroetz, DT Ho, JS Rehage, and MR Heithaus. 2019. Movements of juvenile bull sharks in response to a major hurricane within a tropical estuarine nursery area. Estuaries and Coasts doi: 10.1007/s12237-019-00600-7.

Strickland, BA, FJ Vilella, and R Flynt. 2018. Long-term spotlight surveys of American alligators in Mississippi, USA. Herpetological Conservation and Biology 13(2): 331-340.

Strickland, BA, FJ Vilella, and JL Belant. 2016. Scale-dependent habitat selection and size-based dominance in adult male American alligators. PLoS ONE 11(9): e0161814 doi:10.1371/journal.pone.0161814.

Strickland, BA. 2015. Spatial ecology and population estimation of the American alligator (Alligator mississippiensis) in inland systems of Mississippi. M.S. Thesis, Mississippi State University.

Wisniewski, JM, NM Rankin, DA Weiler, BA Strickland, and HC Chandler. 2014. Use of occupancy modeling to assess the status and habitat relationships of freshwater mussels in the lower Flint River, Georgia, USA. Journal of the Freshwater Mollusk Conservation Society 17(1): 24-40.

Wisniewski, JM, NM Rankin, DA Weiler, BA Strickland, and HC Chandler. 2013. Occupancy and detection of benthic macroinvertebrates: a case study of unionids in the lower Flint River, Georgia, USA. Freshwater Science 32(4): 1122-1135. 